Ana Lúcia S. Sgambatti de Andrade

\title{
AVALIAÇÃO DE POSSÍVEIS FATORES DE RISCO PARA A INFECÇÃO PELO Trypanosoma cruzi EM CRIANÇAS - ESTUDO CASO-CONTROLE EM ÁREA RURAL DO ESTADO DE GOIÁS.
}

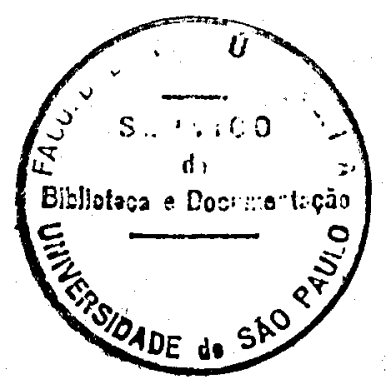

Tese apresentada à Faculdade de Saúde Pública da Universidade de São Paulo, Departamento de Epidemiologia, para obtenção do título de Doutor em Saúde Pública.

Orientador: José Maria Pacheco de Souza 
Ana Lúcia S. Sgambatti de Andrade

\section{AVALIAÇÃO DE POSSÍVEIS FATORES DE RISCO PARA A INFECÇÃO PELO Trypanosoma cruzi EM CRIANÇAS - ESTUDO CASO-CONTROLE EM ÁREA RURAL DO ESTADO DE GOIÁS.}

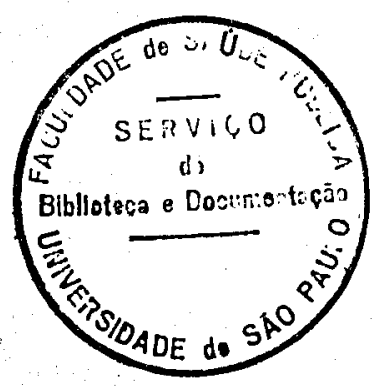

Tese apresentada à Faculdade de Saúde Pública da Universidade de São Paulo, Departamento de Epidemiologia, para obtenção do título de Doutor em Saúde Pública.

Orientador: José Maria Pacheco de Souza 
ANDRADE A.L.S.S. Avaliação de possíveis fatores de risco para infecção pelo Trypanosoma cruzi em crianças. Estudo caso-controle em área rural do Estado de Goiás. São Paulo, 1994. [Tese de Doutoramento - Faculdade de Saúde Pública da USP].

\section{RESUMO}

Um estudo caso-controle para investigar possíveis fatores de risco associados à infecção pelo Trypanosoma cruzi foi realizado em crianças de zona rural, dos municípios de Posse, Simolândia e Guarani de Goiás, localizados na região nordeste do Estado de Goiás.

Os participantes do estudo foram selecionados entre 1.990 crianças de 7 a 12 anos de 60 escolas rurais, mediante triagem sorológica com coleta de sangue em papel de filtro por 3 técnicas: Imunofluorescência Indireta, Hemaglutinação Indireta e ELISA.

Cento e quarenta e nove (149) crianças com presença de anticorpos anti-T. cruzi em pelo menos 2 testes realizados em amostras de sangue venoso e uma amostra aleatória de 298 crianças soronegativas para os 3 testes, pareadas por sexo, freqüência de idade e comunidade foram incluídas no estudo, respectivamente como Casos e Controles.

As moradias dos casos e controles foram visitadas para obtenção de informações sobre presença de vetores na unidade domiciliar, características do domicílio, da família e do ambiente peridoméstico. Nessa ocasião foram coletadas amostras de sangue dos pais dos participantes do estudo.

Casos e controles foram comparados em relação a fatores de risco relativos ao ambiente doméstico, peridoméstico e sorologia dos pais. Um segundo banco de dados foi construído com apenas um participante por moradia, correspondendo a 89 
moradias de casos e 278 de controles. O modelo de regressão logística condicional foi empregado para controlar as principais variáveis de confusão. Sensibilidade de variáveis preditoras da casa da criança infectada foi também calculada.

Uma associação estatisticamente significante foi encontrada entre criança soropositiva e evidência de vetor, ou seus vestígios, no domicílio. A presença de exúvia foi o maior preditor de criança infectada (OR=3,5; LC95\% 2,1-5,8), enquanto a presença de vetor sem deteç̧ão de vestígios não esteve associada à criança infectada. A identificação de triatomíneos pelos moradores apresentou $\mathrm{OR}=7,7$ (LC95\% 2,3-25,5). A infecção em crianças esteve significativamente associada ao número de pessoas residentes na moradia atual. Uma maior proporção de pessoas soropositivas foi detectada nas casas dos casos quando comparada às casas do grupo controle sugerindo uma possível agregação familiar da soropositividade. Características peridomésticas foram semelhantes entre casos e controles, não havendo diferenças de $\mathrm{OR}$ entre os dois grupos. Detectou-se associação significativa entre mãe soropositiva e filho soropositivo $(O R=3,6$; LC95\% 2,1-6,5), indicando a possibilidade da transmissão congênita ou um potencial efeito prejudicial exercido pela soropositividade de mães de recémnascidos não infectados congenitamente. Entretanto, a associação entre pai infectado e filho infectado não foi estatisticamente significante (OR=1,6; LC95\% 1,0-2,7). O relato de vetores pelos moradores mostrou uma sensibilidade de $97,5 \%$ em predizer moradia de criança soropositiva.

Os aspectos relativos à aplicação da metodologia caso-controle no estudo da infecção pelo T. cruzi e possíveis medidas de vigilância e controle para a região de estudo são discutidos. 
ANDRADE A.L.S.S. Trypanosoma cruzi infection among children in Brazil: a population-based case-control study. São Paulo, 1994. [Thesis - School of Public Health. University of S. Paulo].

\section{SUMMARY}

A population-based case-control study was conducted in a rural endemic area under routine vector surveillance with the objective of investigating the role of environmental characteristics, family and household factors regarding the risk of $\mathbf{T}$. cruzi infection in childhood.

One thousand nine hundred and ninety schoolchildren, aged 7-12 years, corresponding to $82 \%$ of students enrolled in 60 village primary schools in three contiguous rural counties in Northeast Goiás were screened for T. cruzi infection between March and September, 1991. Blood samples collected on filter paper were tested by indirect haemagglutination (IHA), indirect immunofluorescence (IIF) and enzyme immunosorbent assay (ELISA) and further confirmed by testing venous blood samples.

Cases were 149 children out of the 158 (7.9\%) positive children to anti-T. cruzi antibodies by at least two serological tests. For each case, 2 seronegative controls were selected among classmates, matched by age $(+/-1$ year) and sex. Socio-economical and environmental factors possibly associated with the risk of $\mathbf{T}$. cruzi transmission were recorded by interviewing parents of cases and controls. Domestic and peridomestic entomological evaluation was done by using pyrethrum as a flushing out agent. A venous blood sample was taken from parents of cases and controls to be tested for anti-T. cruzi antibodies by the same three techniques. Cases and matched controls were compared regarding three groups of variables: parents' serology, housing characteristics and peridomestic environment. To control for common exposures among household members and to avoid cluster of seropositive, further analyses were also performed considering only one case and 
one control per household ( 89 households of case and 278 households of controls).

Conditional logistic regression models (CLR) were used to control for confounding variables and the sensitivity in identifying a house with a positive child was also estimated. Triatomine infestation or evidence of triatomine colonization in the houses were found to be statistically associated to children seropositivity. The presence of exuviae was the strongest predictor of infected children $(\mathrm{OR}=3.5$; 95\%CL 2.1-5.8). Parents who reported triatomine bugs inside or outside the house in the last 5 years had odds ratio of 7.7 (95\%CL 2.3-25.5) of having an infected child. There was an increased risk of seroreactivity among children associated to the number of family members. Higher proportion of seropositive individuals was found in the household of cases when compared to the household of controls, suggesting familial aggregation. Cases and controls shared similar environmental and peridomestic characteristics. A strong association was found between mother's serology and child anti-T. cruzi antibodies ( $\mathrm{OR}=3.6 ; 95 \% \mathrm{CL} 2.1-6.5)$ but no statistical association was found between seropositivity of father and child serology $(\mathrm{OR}=1.6 ; 95 \% \mathrm{CL} 1.0-2.7)$. Similar results were obtained after excluding cases and controls living in the same household. The possibility of transplacental T. cruzi transmission and its implication for Chagas disease control was considered. Among the variables used as predictors of a house with a seropositive child the report of vector presence by householders showed a $97.5 \%$ sensitivity. The capture of triatomine vectors in the dwelling was not correlated to a seropositive house. The methodological issues regarding case-control approach in T. cruzi infection and public health interventions for the study area were discussed. 


\section{ÍNDICE}

Resumo

Summary

Índice

Lista de Tabelas

Lista de Figuras

Agradecimentos

Apresentação

página

1. INTRODUÇÃo ................... 1

1.1 Aspectos epidemiológicos da infecção pelo Trypanosoma cruzi . . . . . . . . . . . . . . . . 2

a. Transmissão vetorial $\ldots \ldots \ldots \ldots \ldots \ldots$

b. Transmissão congênita . . . . . . . . . . . . . . 9

c. Transmissão transfusional . . . . . . . . . . . . . . . 16

1.2 Soroepidemiologia da infecção pelo Trypanosoma cruzi . . . . . . . . 23

1.3 Indicadores epidemiológicos de vigilância e controle . . . . . . . . 33

a. Indicadores entomológicos . . . . . . . . . . . . . . . . 34

b. Indicadores sorológicos relacionados com a transmissão do Trypanosoma cruzi .................... 37

2. JUSTIFICATIVA ....................... 44

3. OBJETIVOS $\ldots \ldots \ldots \ldots \ldots \ldots \ldots \ldots \ldots \ldots \ldots \ldots \ldots$

4. METODOLOGIA . . . . . . . . . . . . . . . . . 50

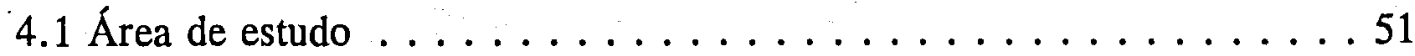

4.2 População de estudo . . . . . . . . . . . . . . . . . . 55

4.3 Delineamento do estudo; fluxograma de atividades . . . . . . . . . 55

4.4 Amostragem e amostra . . . . . . . . . . . . . . . . . 60

4.5 Definição e seleção de casos e controles . . . . . . . . . . . . . 61

4.6 Exames sorológicos . . . . . . . . . . . . . . . 67 
página

4.7 Avaliação de possíveis fatores de risco . . . . . . . . . . . . 73

4.8 Processamento e análise dos dados . . . . . . . . . . . . 77

4.9 Considerações éticas . . . . . . . . . . . . . . . . . . 79

5. RESULTADOS ......................... 80

5.1 Características dos casos e dos controles . . . . . . . . . . 81

5.2 Avaliação de fatores de risco associados à infecção pelo T. cruzi . . . . 83

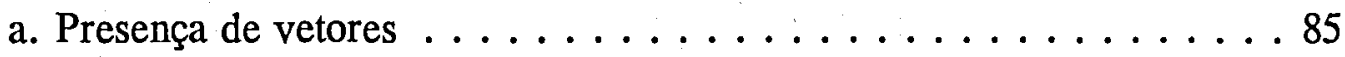

b. Características do domicílio . . . . . . . . . . . . . . 90

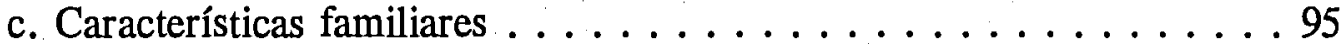

d. Características do peridomicílio . . . . . . . . . . . . 110

e. $\operatorname{Resumo~\ldots .......................~.~.~.~.~} 110$

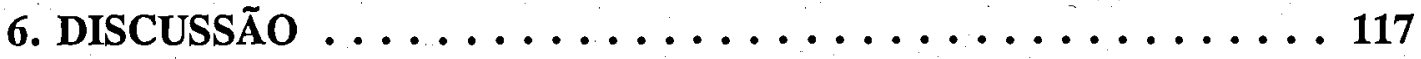

6.1 Considerações metodológicas $\ldots \ldots \ldots \ldots \ldots \ldots$

6.2 Fatores associados à transmissão $\ldots \ldots \ldots \ldots . \ldots \ldots$

7. CONCLUSÕES ... . . . . . . . . . . . . . . . . 139

8. REFERÊNCIAS BIBLIOGRÁFICAS . . . . . . . . . . . . 142

ANEXO 1. Ficha de identificação .................. A1

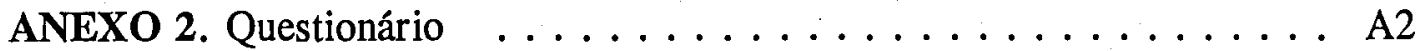

ANEXO 3. Roteiro para preenchimento do questionário . . . . . . . . . . A10

ANEXO 4. Cálculo do odds ratio pareado - Mantel-Haenszel . . . . . . . . . A18 


\section{LISTA DE TABELAS}

página

\section{Metodologia}

Tabela 4.5-1

Distribuição do número de casos e controles por moradia

de acordo com o banco de dados. . . . . . . . . . . . . . . . . . 66

\section{Resultados}

5.1 Características dos casos e controles

Tabela 5.1-1

Número e porcentagem de crianças segundo diversas características e reação sorológica ao Trypanosoma cruzi. Banco de dados $1 .$. . . . . . . . . . . . 82

Tabela 5.1-2

Número e porcentagem de crianças segundo diversas características e reação sorológica ao Trypanosoma cruzi. Banco de dados 2, somente um participante por moradia. . . . . . . . . . . . . . . . . . . . 84

5.2 Associação de fatores de risco associados à infecção pelo

\section{Trypanosoma cruzi}

\section{Tabela 5.2-1}

Casos e controles de acordo com número de triplos expostos à variável identificação de triatomínio, estratificada por domicílio e anexo, com os respectivos odds ratios (OR) pareados e limites de confiança (LC) 95\%.. . 86

Tabela 5.2-2

Casos e controles de acordo com número de triplos expostos à variável identificação de triatomíneo, estratificada. .............. 87

Tabela 5.2-3

Casos e controles de acordo com número de triplos expostos à variável moradia infestada, presença de triatomíneo, exúvia, cório e fezes, com os respectivos odds ratios (OR) pareados e limites de confiança $(\mathrm{LC})$ de $95 \%$. . . . . . . . . . . . . . . 88 
página

Tabela 5.2-4

Casos e controles de acordo com número de triplos expostos à variável moradia infestada, exúvia, cório e fezes, com os respectivos odds ratios (OR) pareados e limites de confiança (LC) de $95 \%$. Banco de dados 2, somente um participante por moradia. . . . . . 89

Tabela 5.2-5

Casos e controles de acordo com número de triplos expostos à variável captura de triatomíneo, classificada por unidade domiciliar e espécie de triatomíneo no domicílio e anexo com os respectivos odds ratios (OR) pareados e limites de confiança (LC) de $95 \%$. Banco de dados 2 ,

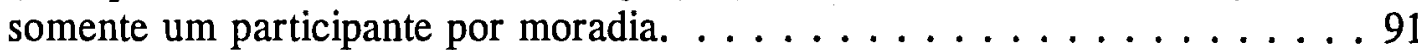

Tabela 5.2-6

Casos e controles de acordo com número de triplos expostos à variável características do domicílio, classificada por tipo de parede, teto, piso, habitação e número de cômodos, com os respectivos odds ratios (OR) pareados e limites de confiança (LC) de $95 \%$. Banco de dados 2, somente um participante por moradia. . . . . . . . . . . . . . 93

Tabela 5.2-7

Casos e controles de acordo com número de triplos expostos às variáveis relativas ao ambiente doméstico, com os respectivos odds ratios (OR) pareados e limites de confiança (LC) de $95 \%$. . . . . . . . . . . . 97

Tabela 5.2-8

Casos e controles de acordo com número de triplos expostos à soropositividade dos pais, com os respectivos odds ratios (OR) pareados e limites de confiança (LC) de $95 \% . \ldots \ldots \ldots \ldots \ldots \ldots \ldots \ldots \ldots \ldots$

Tabela 5.2-9

Casos e controles de acordo com número de triplos expostos à soropositividade da mãe, segundo sexo e idade, com os respectivos odds ratios (OR) pareados e limites de confiança (LC) de $95 \%$. . . . . . . . . . . . . 99

Tabela 5.2-10

Número de casos e controles expostos à soropositividade da mãe, segundo sexo, idade e moradia infestada, com os respectivos odds ratios (OR) e limites de confiança (LC) de $95 \% \ldots \ldots \ldots \ldots \ldots \ldots \ldots$

Tabela 5.2-11

Número de casos e controles expostos à soropositividade da mãe estratificada por sorologia do pai, com os respectivos odds ratios (OR) não pareados e limites de confiança (LC) de $95 \%$. . . . . . . . . . . . . . 102 
página

Tabela 5.2-12

Casos e controles de acordo com número de triplos expostos à soropositividade dos pais, com os respectivos odds ratios (OR) pareados e ajustados por variáveis de confusão e limites de confiança (LC) de $95 \%$. Banco de dados 2 , somente um participante por moradia. . . . . . . . . 103

Tabela 5.2-13

Número de casos e controles expostos a variáveis relativas ao vetor e soropositividade dos pais e sensibilidade das variáveis para detecção de criança soropositiva (caso) e criança soronegativa (controle). Banco de dados 2 , somente um participante por moradia. . . . . . . . . 106

Tabela 5.2-14

Casos e controles de acordo com número de triplos expostos às características familiares com os respectivos odds ratios (OR) pareados e limites de confiança (LC) de $95 \%$. . . . . . . . . . . . . . . . 107

Tabela 5.2-15

Casos e controles de acordo com o número de triplos expostos às características sociais com os respectivos odds ratios (OR) pareados e limites de confiança (LC) de $95 \%$. Banco de dados 2, somente um participante por moradia. . 108

Tabela 5.2-16

Casos e controles de acordo com número de triplos expostos à presença de anexos, entulhos, palmeiras e ninho de graveteiro no peridomicílio, com os respectivos odds ratios (OR) pareados e limites de confiança (LC) de $95 \% .112$

Tabela 5.2-17

Casos e controles de acordo com número de triplos expostos à presença de anexos, entulhos, palmeiras e ninho de graveteiro no peridomicílio, com os respectivos odds ratio (OR) pareados e limites de confiança (LC) de $95 \%$. Banco de dados 2, somente um participante por moradia. . . . . . . . 113

Tabela 5.2-18

Resumo da associação de variáveis investigadas para infecção pelo Trypanosoma cruzi em crianças de área rural. . . . . . . . . 116 


\section{LISTA DE FIGURAS}

\section{Metodologia}

página

Figura 4.1-1

Região Nordeste de Goiás dividida em microrregiões de acordo com a FIBGE.53

Figura 4.1-2

Indicadores entomológicos do município de Posse, Goiás. . . . . . . . . . . . 54

Figura 4.3-1

Área de estudo com as 46 localidades rurais nas quais os participantes

do estudo foram selecionados. . . . . . . . . . . . . . . . . 56

Figura 4.3-2

Fluxograma do trabalho de campo. . . . . . . . . . . . . . 59

Figura 4.4-1

Tamanho da amostra para estudo de caso-controle (1:2) versus exposição em

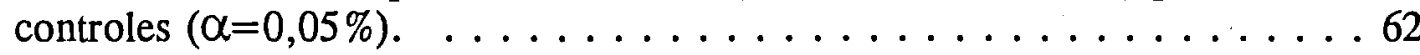

Figura 4.5-1

Fluxograma para seleção de casos e controles. . . . . . . . . . . . . 65

Figura 4.6-1

Papéis de filtro em processo de secagem. . . . . . . . . . . . . 72

Figura 4.6-2

Papéis de filtro embalados para transporte. . . . . . . . . . . . 72

Figura 4.7-1

Captura de triatomíneo na moradia. . . . . . . . . . . . 76

Figura 4.7-2

Pesquisa de triatomíneo em galinheiro prévia à borrifação com inseticida. . . 76 
página

\section{Resultados}

Figura 5.2-1

Distribuicão do tipo de parede das 267 casas de casos e controles. . . . . . . . 92

Figura 5.2-2

Exemplo de moradia da região de estudo. . . . . . . . . . . . . . . . . . . 94

Figura 5.2-3

Proporção de pessoas soropositivas nas casas de casos e controles. . . . . . . 109

Figura 5.2-4

Tipo de galinheiro freqüente na área de estudo. . . . . . . . . . . . . . . . 114

Figura 5.2-5

Tipo de chiqueiro freqüente na região. . . . . . . . . . . . . . . . . 114

Figura 5.2-6

Paiol aberto no peridomicílio. . . . . . . . . . . . . . . . . 115

Figura 5.2-7

Ninho de graveteiro no peridomicílio. . . . . . . . . . . . . . . . . 115 
A João, Soraya, Sabrina e Marcel, com amor. 


\section{AGRADECIMENTOS}

Ao Professor José Maria Pacheco de Souza, orientador competente, pelo apoio e estímulo em todas as etapas do trabalho.

Ao Professor Renato M. Oliveira pela coordenação do trabalho de campo, Professor Ionizete G. Silva pela supervisão da avaliação entomológica e aos residentes de Medicina Preventiva e Social pelo auxílio nas diversas fases do trabalho de campo. A todos os funcionários da Fundação Nacional de Saúde que estiveram envolvidos no trabalho de campo.

Ao Professor Alejandro O. Luquetti pela realização dos testes sorológicos.

A Professora Celina M. Turchi Martelli pela competente e incansável parceria na estratégia de análise de dados, pelas inúmeras sugestões na redação do texto e permanente estímulo intelectual.

A Professora Simonne A. Silva pelo inestimável e eficiente auxílio na supervisão do processamento dos dados e computação gráfica.

A Marcos A. Chaves e João B. Peres Jr. pelo processamento de dados e digitação e a Divina Helena Rezende pelo cuidadoso trabalho de secretaria.

Aos colegas do Departamento de Saúde Coletiva, em especial ao Professor Paulo O. Macedo, chefe deste departamento durante a investigação de campo e à direção do Instituto de Patologia Tropical e Saúde Pública, nas pessoas dos Professores Roberto R. Daher e Dulcinéa Barbosa Campos pelo apoio logístico em todas as fases da investigação. 
Ao Professor José Maria Barata pelos valiosos comentários na fase de redação e à Professora Maria Carolina Guimarães pelos ensinamentos e discussões em soroepidemiologia, durante o estágio em seu laboratório.

Meu agradecimento especial ao Professor Fábio Zicker, responsável por minha iniciação em epidemiologia e que estabeleceu, regionalmente, uma linha de pesquisa populacional em Doença de Chagas, propiciando as condições para a realização deste trabalho. Não saberia agradecer em poucas palavras o permanente apoio, clima de seriedade, dedicação, competência e formação intelectual nesses anos de convivência, que a sua grandeza tem proporcionado a todos nós.

Ao UNDP/World Bank/WHO/TDR-Special Programme for Research and Training in Tropical Diseases e ao CNPq pelo suporte financeiro e a CAPES pela concessão de minha bolsa de estudos. 


\section{APRESENTAÇĀO}

Neste trabalho são apresentados e discutidos resultados de um estudo casocontrole sobre infecção pelo Trypanosoma cruzi, realizado com escolares de áreas rurais de municípios do nordeste do Estado de Goiás. O objetivo foi avaliar possíveis fatores de risco associados à infecção pelo T. cruzi na infância.

O estudo explora as potencialidades da metodologia caso-controle no processo de vigilância da infecção pelo $T$. cruzi na área de estudo. As características do delineamento caso-controle deste trabalho permitiram que as taxas de exposição entre os controles pudessem ser utilizadas como representativas da população em geral. Nestas circunstâncias, as implicações do ponto de vista de saúde pública relativas aos achados deste estudo são discutidas.

O Capítulo 1 revisa os mecanismos da transmissão da infecção pelo T. cruzi, com enfoque nos estudos de transmissão vetorial, congênita e transfusional. Ainda nesse capítulo foi incluída uma análise crítica dos aspectos epidemiológicos relativos ao uso de testes sorológicos para detecção de infecção pelo T. cruzi e dos principais indicadores epidemiológicos para vigilância e controle da infecção. A justificativa e os objetivos do estudo são apresentados nos capítulos 2 e 3 . O capitulo 4 apresenta uma descrição detalhada da metodologia, incluindo área e população de estudo, delineamento do estudo, tamanho da amostra, definição e seleção de casos e controles, testes sorológicos realizados, medidas de exposição e análise dos dados. Os resultados dos fatores de risco investigados são descritos no capitulo 5, dentro de 4 sub-itens: presença de vetores, características do domicílio, da família e do peridomicílio. A discussão é apresentada no capítulo 6, focalizando vantagens e desvantagens do uso da metodologia caso-controle no estudo da infecção pelo T. cruzi em crianças. Conclusões e sugestões, especialmente para o programa de controle da doença de Chagas na região e para novas linhas de 
pesquisa, são apresentadas no capitulo 7. Uma cópia dos formulários originais utilizados neste estudo encontram-se nos Anexos 1, 2 e 3, respectivamente, ficha de identificação, questionário e roteiro para preenchimento do questionário e o Anexo 4 apresenta a fórmula utilizada para o cálculo do odds ratio pareado. 
1. INTRODUÇÃO 


\subsection{Aspectos epidemiológicos da infecção pelo Trypanosoma cruzi}

O Trypanosoma cruzi é um protozoário hemoflagelado, agente causal da doença de Chagas ou tripanosomíase americana, antropozoonose que ocorre somente no continente americano. De acordo com a Organização Mundial de Saúde, 16 milhões de indivíduos encontram-se infectados pelo T. cruzi na América Latina e aproximadamente 90 milhões estariam sob risco de se infectar. O Brasil contribui com 40\% (6 milhões) desse total de infectados (WHO, 1990; Moncayo, 1992).

A infecção é transmitida ao homem principalmente pela picada de triatomíneos, por transfusão de sangue contaminado e por via transplacentária. Trata-se de infecção crônica, endêmica de populações rurais e relacionada à falta de desenvolvimento sócio-econômico. A infecção é mais prevalente em áreas subdesenvolvidas, onde o vetor é encontrado em habitações de pau-a-pique e/ou adobe.

A relevância da infecção ou doença de Chagas, do ponto de vista de saúde pública, baseia-se nos seguintes aspectos: a) é uma enzootia silvestre que acomete o homem como consequeência de alterações provocadas no meio ambiente pelo próprio homem; b) a infecção no homem está relacionada à baixa condição sócioeconômica e condições desfavoráveis de moradia; c) ausência de tratamento efetivo para a infecção ou para a prevenção de manifestações clínicas e d) ausência de vacina disponível (Frasch et al., 1990).

A transmissão do T.cruzi para o homem está associada a interações bioecológicas entre indivíduos susceptíveis e triatomíneo e a características sócioculturais e econômicas da população sob risco. O principal reservatório para a transmissão do T.cruzi no ciclo domiciliar é o homem. Tem sido descrito que cães e gatos têm um papel importante como reservatórios do T.cruzi, associado ao Panstrongylus megistus, vetor encontrado nos domicílios da região nordeste do 
Brasil (Mott et al., 1978) e considerado o principal reservatório de infecção pelo T.cruzi na Argentina (Winisvesky-Colli et al., 1985; Gurtler et al., 1987). Estudos descritivos têm mencionado a significância ecológica e epidemiológica de roedores, especialmente como fonte de alimentação para os triatomíneos, auxiliando a manter ou aumentar a densidade populacional de vetores domésticos e peridomésticos podendo servir como predadores de triatomíneos. A ausência de local apropriado para armazenagem de produtos da colheita contribui para acumular grandes quantidades de alimentos/grãos dentro da habitação, que atraem ratos que servem como reservatórios para o T.cruzi (Dias \& Dias, 1982; WHO, 1991).

As precárias condições do ambiente doméstico e peridoméstico em áreas rurais favorecem a adaptação e colonização de triatomíneos. Fatores relacionados à presença de triatomíneos no domicílio têm sido relatados em estudos descritivos (Dias \& Dias, 1982). A importância do peridomicílio como ecótopo para os vetores e como elo entre os ciclos silvestres e doméstico, bem como o papel de animais peridomésticos como fonte de alimentação e reservatório para espécies secundárias têm sido extensamente documentados (Dias, 1988; Bos, 1988). Por este motivo, além de contínua vigilância de focos residuais de triatomíneos intra-domicílio, atualmente a prioridade nas atividades de controle de vetores tem sido monitorar o ambiente peridoméstico para detectar eventual invasão de moradias por vetores secundários (Dias, 1993).

Tradicionalmente o programa de controle da doença de Chagas tem sido organizado de forma independente, -com uma estrutura vertical e de natureza biomédica por excelência. A necessidade de uma abordagem intersetorial, associada a políticas de organização do espaço e ordenamento do meio, torna-se evidente para os programas tradicionais. $\mathrm{O}$ conceito de vigilância em relação à doença de Chagas deve abordar o processo saúde-doença de forma global e enfatizar a vigilância do processo sócio-econômico, grande determinante da manutenção e expansão da endemia no Brasil. Neste aspecto, a vigilância da infecção pelo T. cruzi deve ser ampliada para todo o processo subjacente à ocorrência e dispersão da infecção (Dias, 1991). 
Os principais mecanismos relativos à infecção pelo T. cruzi serão abordados neste capítulo, priorizando-se os estudos em que foi utilizado o método epidemiológico com vistas ao controle de sua transmissão.

\section{a. Transmissão vetorial}

Mais de $80 \%$ dos casos de doença de Chagas são adquiridos por transmissão através de vetores (Dias, 1987). Os vetores naturais do T. cruzi são insetos da ordem Hemiptera, família Reduviidae, sub-família Triatominae. Um grande número de triatomíneos é conhecido, sendo que no Brasil 8 gêneros e mais de 40 espécies já foram descritos. No entanto, apenas 5 triatomíneos apresentam significado epidemiológico como vetores do $T$. cruzi no Brasil: Triatoma infestans, Panstrongylus megistus, Triatoma brasiliensis, Triatoma pseudomaculata e Triatoma sordida (Castro-Filho \& Silveira, 1979; Dias, 1987). A partir de resultados do inquérito entomológico, realizado pelo Ministério da Saúde, no Brasil em 1975, detectaram-se em Goiás $53 \%$ de T. infestans e $31 \%$ de T. sordida, do total de triatomíneos capturados (Castro-Filho \& Silveira, 1979).

Informações obtidas posteriormente, no período 1975-1983, referentes à busca ativa de triatomíneos realizada por técnicos da SUCAM, confirmaram a importância dessas espécies como vetoras da doença de Chagas no Brasil. Nesse estudo, P. megistus foi o triatomíneo mais difusamente distribuído no país, enquanto o T. sordida foi a espécie mais freqüente, especialmente encontrada associada a aves no peridomicílo. No Estado de Goiás, $67 \%$ dos triatomíneos capturados foram T. sordida (Silveira et al., 1984).

Mais recentemente, dados da Fundação Nacional de Saúde mostraram uma redução de mais de $80 \%$ nas taxas de infestação pelo T.infestans nos municípios infestados por esta espécie, nos últimos 10 anos, e $75 \%$ dos triatomíneos haviam sido detectados no peridomicílio (Dias, 1993). 
A capacidade vetorial de uma espécie de triatomíneo depende de fatores complexos relacionados, principalmente, à susceptibilidade da espécie à infecção e de sua adaptação ao domicílio humano. Sousa (1988), em revisão sobre o tema, 'descreve vários fatores relacionados a esses aspectos: a) fatores genéticos que afetam a resistência à infecção; b) quantidade de sangue ingerido e/ou número de parasitas ingeridos; c) tipo ou estágio de tripomastigotas presentes no sangue ingerido; d) adaptação a cepas geográficas locais de T. cruzi para as quais o triatomíneo é vetor natural; e) idade e estágio de ninfa do inseto; f) habilidade em estabelecer infecção das glândulas do reto e desenvolver metaciclogêneses; g) cinética de transformação e ciclo de vida no aparelho digestivo do inseto; h) cepas de T. cruzi ou características e natureza dos clones; i) efeito da temperatura e j) dinâmica da população de insetos (Sousa, 1988). A partir dos anos 80, a pesquisa nesse campo vem sendo dirigida, principalmente, para o efeito da temperatura $\mathrm{e}$ para os estudos da dinâmica da população de vetores, especialmente do T. infestans.

O T. infestans é considerado o vetor mais eficiente, sendo a espécie mais adaptada ao ambiente doméstico de moradias rurais. Na região centro-oeste do Brasil, o T. sordida tem-se mostrado menos vulnerável à ação de inseticidas, tendo como habitat o ambiente silvestre e peridoméstico, principalmente galinheiros. Este vetor apresenta grande capacidade de colonizar moradias onde o $\mathbf{T}$. infestans haja sido eliminado (Forattini et al., 1971; Silveira et al., 1984; Garcia-Zapata \& Marsden, 1992).

Forattini et al. (1973) demonstraram a capacidade invasiva de populações silvestres de T. sordida de colonizar galinheiros experimentais, em estudos de campo conduzidos na região de Araraquara, São Paulo. Os autores alertaram para a possibilidade de infestação do ambiente doméstico por esse vetor no futuro, devido às alterações do meio ambiente e manutenção de habitações rurais precárias. Resultados semelhantes foram descritos na década seguinte, em Minas Gerais, também por Forattini et al. (1983a), que estudaram a domicialização de triatomíneos 
em cinco áreas submetidas à intervenção com inseticida e em uma área controle sem intervenção. Galinheiros artificiais foram instalados no ambiente peridoméstico, ocupados por anexos tais como paióis, chiqueiros, currais, pastagens e lavouras. Levantamento entomológico foi realizado antes e após a desinsetização, detectando-se uma intensa invasão dos anexos do peridomicílio, especialmente pelo T. sordida, aumentando-se os percentuais de infestação de $70 \%$ para $96 \%$ no peridomicílio, após a aplicação do inseticida no domicílio.

Ainda nessa linha de pesquisa, Forattini et al. (1983b), acompanhando o desenvolvimento de colônias de T. sordida, observaram que a produção de exemplares adultos no extradomicílio esteve simultaneamente associada à invasão do domicílio. Essa invasão domiciliar por populações extradomiciliares de T. sordida ocorreu nos primeiros meses do ano. Neste sentido, o conhecimento desses resultados tem importância na definição de épocas estrategicamente apropriadas para atividades de vigilância de vetores.

Em inquérito entomológico realizado no Estado de Goiás, através de captura mensal de triatomíneos em 16 microrregiões do Estado, a espécie predominante foi o T. sordida, com tendência crescente dos percentuais de infestação durante os anos de 1976 a 1980, variando de $42 \%$ a $73 \%$ (Lustosa et al., 1984).

Forattini et al. (1984) estudaram os mecanismos da domicialização de colônias de P. megistus através de acompanhamento desse vetor em galinheiros experimentais. Os autores verificaram nos galinheiros do-peridomicílio $\mathrm{e}$ extradomicílio um aumento da proporção de exemplares adultos, principalmente no mês de outubro, período considerado como infestante para o ambiente domiciliar. Esses achados constituem informações úteis no processo de vigilância da reinfestação por $\mathbf{P}$. megistus, em áreas submetidas à desinsetização.

A transmissão do T. cruzi para o homem depende principalmente da dinâmica da população de triatomíneos e da taxa de contacto entre o vetor e 0 
homem. A densidade de vetores é uma das variáveis que determina a probabilidade de transmissão do T. cruzi ao homem. A hipótese de que a quantidade de sangue disponivel seja de fundamental importância na regulação da densidade da população de T. infestans foi testada por Gorla \& Schofield (1989), em estudo de campo realizado na Argentina. Três grupos experimentais, cada um composto por 3 galinheiros de adobe e tijolo, contendo T. infestans (ovos, ninfas, adultos), foram acompanhados durante o período de 1981 a 1984. O número de triatomíneos mostrou marcada sazonalidade, com aumentos no verão e diminuição no inverno. Os autores concluíram que a densidade populacional de vetores depende mais da disponibilidade de hospedeiros do que da taxa de mortalidade, o que reflete no desenvolvimento da população de T. infestans. Assim, este efeito da sazonalidade na população de T. infestans adquire importância em relação à efetividade das medidas de controle contra o vetor, quando aplicadas em diferentes épocas do ano, provavelmente com maior impacto no início do inverno. Este procedimento impediria o desenvolvimento dos sobreviventes nos meses mais frios. Por outro lado, a aplicação de inseticidas, ao final do inverno, seria acompanhada de taxas máximas de desenvolvimento de triatomíneos sobreviventes (Gorla \& Schofield, 1989).

Gorla (1991), também estudou a eficácia da aplicação de inseticidas nas diferentes estações do ano, através de um ensaio de campo controlado, conduzido na Argentina. Galinheiros foram construídos com adobe e tijolo, colonizados com $626 \mathrm{~T}$. infestans e alocados aleatoriamente a 5 grupos de intervenção, incluindo um grupo controle e 4 grupos submetidos a inseticidas em cada estação do ano. $O$ estudo mostrou que a dinâmica da população de vetores foi influenciada pela estação do ano em que o inseticida foi aplicado. Para a região de estudo, o maior impacto na densidade do T. infestans foi alcançado no outono, fato este observado em estudos anteriores, conduzidos pelo mesmo autor (Gorla, 1988); assim, estes achados poderiam ser explicados pelo desaparecimento das fêmeas após a aplicação do inseticida, supondo que, nessa estação, as fêmeas apresentariam uma suceptibilidade maior aos inseticidas, provavelmente devido às condições fisiológicas 
decorrentes do período pós-reprodutivo, ocorrido no verão. No entanto, em todos os grupos tratados com inseticida, ocorreu recuperação da população de triatomíneo aos níveis da densidade das populações do grupo controle no período de 1 a 3 anos o que mostra o alto potencial do $\mathbf{T}$. infestans de recuperar-se de densidades populacionais muito baixas (Gorla, 1991).

Catalá (1991) enfatiza que o desenvolvimento do triatomíneo ou da população de vetores depende essencialmente da quantidade de sangue ingerido. Neste aspecto, a freqüência de picadas passa a ser determinante da dinâmica da população de vetores. Em estudo conduzido na mesma região da Argentina, com T. infestans mantidos em galinheiros artificiais, $o$ autor analisou a presença de cor na urina do triatomíneo como indicador de ingestão recente de sangue. Os insetos foram estudados mensalmente, e um modelo matemático foi utilizado para predizer a proporção de vetores na população que se alimentaram nas últimas 24 horas. Nesse estudo, a temperatura exerceu efeito importante na proporção de vetores que ingeriram sangue. Nas estações de clima quente, ocorreu maior freqüência de ingestão de sangue pelos insetos, conduzindo a altas densidades de vetores.

De acordo com Schofield (1991), tem-se conseguido a redução da população de vetores, assim como das taxas de infestação e de transmissão de doenças; porém o problema principal não é alcançar a redução inicial da doença através da fase de ataque com inseticidas, mas sua manutenção em níveis aceitáveis, através de um intenso sistema de vigilância. Como exemplo, o autor menciona os estudos realizados por Wisnivesky-Colli et al. (1987) na Argentina, onde a taxa de infestação das moradias foi reduzida aparentemente a zero, mas retornou aos valores iniciais após 2 anos. A reinfestação, quer seja por população residual de vetores ou por nova população de triatomíneo, ou ambos, aumentará na dependência da taxa de migração, fato que reforça a importância do processo de vigilância, com ênfase especial na participação da comunidade. Assim, a taxa de infestação tende a retornar aos níveis iniciais, a menos que haja novo tratamento com inseticida. $\mathrm{O}$ autor chama a atenção para o fato de que baixos níveis de transmissão podem ser 
alcançados, mas a população de vetores e as taxas de transmissão da doença tendem a aumentar, caso poucos exemplares de triatomíneos ainda persistam.

Neste sentido, no balanço das perdas e ganhos do programa de controle da doença de Chagas, Schofield \& Dias (1991) mostram que após uma fase de ataque de cerca de 3 anos de duração, seguida de 7 anos de monitoramento vetorial, a fase de vigilância é responsável por somente $9 \%$ dos gastos acumulados, porém contribui com mais de $83 \%$ dos benefícios acumulados. Desta forma, o conhecimento da dinâmica populacional passa a ser de fundamental importância para orientar propostas de implementação dos programas de intervenção, especialmente tendo em vista a política atual de erradicação do T. infestans do Cone Sul (Schofield, 1992).

\section{b. Transmissão congênita}

Doze anos após a descoberta da doença de Chagas, surgiram os primeiros trabalhos que mostraram experimentalmente a possibilidade de transmissão congênita da doença (Nattan-Larrier, 1921; Villela, 1923). No entanto, somente após 40 anos foi comprovado o primeiro caso humano de transmissão congênita com a descrição do T. cruzi, em sangue periférico de recém-nascido (Dao, 1949).

Dentre os mecanismos de transmissão mais prováveis está a infecção transplacentária com passagem do T. cruzi para o epitélio corial e estroma vilositário, atingindo a circulação fetal. Embora raro, pode haver transmissão lactogênica na fase aguda da doença de Chagas, com parasitismo do leite. Na fase crônica, a transmissão pelo leite ainda não foi comprovada (Bittencourt, 1987).

A maior parte dos estudos sobre incidência de transmissão congênita da infecção ou doença de Chagas é predominantemente de estudos de prevalência. Raros foram os estudos de coorte com acompanhamento de recém-nascidos de gestantes infectadas, por períodos e com número de recém-nascidos suficientes para 
se detectar, com poder estatístico, incidência de infecção congênita.

À semelhança do que ocorre com as mulheres em geral, a morbidade nas gestantes infectadas é baixa, sendo a maioria delas assintomática (Bittencourt, 1984a; Howard \& Rubio, 1968), apesar da possibilidade de haver comprometimento cardíaco ou digestivo, detectado por eletrocardiograma ou exames radiológicos (Brabin, 1992). A prevalência de infecção pelo T. cruzi em gestantes varia de $2 \%$ a $51 \%$ em centros urbanos e de $23 \%$ a $81 \%$ em áreas rurais endêmicas da América do Sul (Bittencourt, 1992).

Considerando-se que a soroprevalência de infecção pelo T. cruzi em gestantes de área endêmica é alta, a possibilidade de transmissão congênita nestas regiões não é desprezível. Entretanto, grandes variações geográficas quanto à freqüência de transmissão congênita da infecção ou doença têm sido observadas.

Estudos realizados na Argentina mostram que a incidência da transmissão congênita oscila entre $0,7 \%$ e $10,4 \%$ de acordo com a região (Bittencourt et al., 1991). Recentemente, Zaidenberg \& Segovia (1993), estudando 968 gestantes na Argentina, encontraram uma incidência de 1,2\% de recém-nascidos com doença de Chagas congênita. A soropositividade nas mulheres grávidas foi de $16 \%$, e a incidência de infecção congênita em recém-nascidos de mães soropositivas ao $\mathbf{T}$. cruzi foi de $4 \%$. Em Santa Cruz, Bolívia, Azogue et al. (1985a) detectaram uma prevalência de infecção de $51 \%$ em mulheres grávidas. De 329 recém-nascidos, 25 foram positivos ao T. cruzi, pela pesquisa direta do parasita, mostrando uma alta taxa de incidência $(7,6 \%)$ de infecção congênita. A transmissão foi mais freqüente nos recém-nascidos com peso menor ou igual a $2.500 \mathrm{~g}$ quando comparado aos com peso maior de $2.500 \mathrm{~g}$.

No Brasil, o maior número de publicações sobre transmissão congênita da doença de Chagas é proveniente de estudos conduzidos no Estado da Bahia (Bittencourt, 1984b). Bittencourt et al. (1972), em 500 partos, detectaram uma 
taxa geral de incidência de transmissão congênita de $2 \%$. No entanto, entre filhos de mães chagásicas, a incidência foi de $10,5 \%$, sendo a maioria natimortos. Resultados semelhantes foram observados por Bittencourt et al. (1985b), que detectaram, entre nativivos e natimortos de mães chagásicas, uma incidência de $1,6 \%$ e $10,5 \%$, em recém-nascidos, respectivamente com peso superior e inferior a 2.000 g. Em abortos de mulheres com infecção chagásica, Bittencourt \& Barbosa (1972) encontraram uma incidência de infecção congênita de 6,2\%.

Em Minas Gerais, Oliveira et al. (1960) estudaram 200 gestantes e encontraram $33 \%$ de soropositividade ao $\mathbf{T}$. cruzi, sem diferenças nas taxas de abortamento entre soropositivas e soronegativas. Mota (1992) detectou uma incidênciả de 3,1\% de transmissão de infeç̧ão congênita em 64 conceptos.

Bittencourt (1987) observou, com vários exames de xenodiagnóstico positivos, gestantes na fase crônica que, no curso da gestação, não transmitiram sua infeç̧ão ao concepto. Este fato mostra que outros fatores influenciam a transmissão, além da parasitemia. A relação entre nível de parasitismo pelo T. cruzi e risco de transmissão congênita ainda necessita ser melhor avaliada.

Experimentalmente, já se verificou a existência de relação entre transmișsão congênita da doença de Chagas, patogenicidade da cepa do T. cruzi e capacidade imunológica da placenta. Também já foram mostradas acentuadas diferenças no grau de tropismo placentário entre diferentes cepas do T. cruzi. Em estudo realizado por Andrade (1982) a cepa que apresentou maior incidência de parasitismo na placenta foi a colombiana, enquanto a que teve tropismo menos acentuado foi a prevalente no Estado da Bahia. No entanto, Delgado \& Santos-Buch (1978) observaram, no camundongo, que a passagem transplacentária do T. cruzi está na dependência da patogenicidade da cepa e também da capacidade fagocítica placentária. Estudos de caracterização de cepas do T. cruzi, realizados na Bahia, em mães que transmitiram e que não transmitiram congenitamente sua infecção, mostraram um mesmo padrão morfológico e isoenzimático (Andrade et al., 1973). 
Bittencourt et al. (1985a) verificaram que cepas de T. cruzi enzimaticamente semelhantes podem apresentar comportamentos diferentes em relação à transmissão transplacentária e quanto às formas clínicas e respostas terapêuticas de casos congênitos. Bittencourt \& Gomes (1967), durante o acompanhamento de quatro gestações de uma paciente detectaram transmissão congênita apenas na primeira e terceira gestações, demonstrando que a mesma cepa do T. cruzi pode ter comportamento diferente quanto a transmissão. Por outro lado, Andrade (1982), avaliando experimentalmente $o$ tropismo de diferentes cepas pela placenta, verificou acentuadas diferenças.

Diferentes padrões têm sido descritos em relação aos aspectos clínicos da doença de Chagas congênita. A infecção chagásica congênita pode resultar em abortamento, prematuridade, retardo de crescimento intra-uterino e em óbitos no período perinatal e pode ocorrer em mais de uma gestação. Os recém-nascidos são, freqüentemente, prematuros e/ou pequenos para a idade gestacional (Bittencourt \& Barbosa, 1972; Bittencourt et al., 1972; Bittencourt \& Gomes, 1967; Bittencourt et al., 1974).

As manifestações clínicas podem estar presentes ao nascimento ou aparecer posteriormente. Neste último caso, sendo tardio o diagnóstico, é importante afastar outras vias de transmissão. As manifestações clínicas mais freqüentemente descritas são febre, anemia, cianose, icterícia, lesões purpúricas, edema, tremores, convulsões e hepatoesplenomegalia (Bittencourt et al., 1991). O aumento do fígado e do baço constitui o principal sinal desta enfermidade (Howard \& Rubio, 1968). $\mathrm{Na}$ doença de Chagas congênita, a criança pode nascer a termo, assintomática e com peso adequado para a idade gestacional (Bittencourt, 1984b). Nesses casos, somente a busca cuidadosa do T. cruzi, nos primeiros dias de vida, pode detectar a infecção e permitir que se obtenha a real freqüência da doença de Chagas congênita no recém-nascido. Embora assintomática, a criança infectada pelo T. cruzi pode apresentar alterações muito discretas ao exame clínico que podem ser até consideradas como dentro dos limites da normalidade, tais como fígado 
discretamente aumentado, baço sob o rebordo costal e discreto edema de genitália e de membros inferiores (Medina-Lopes, 1984).

Recentemente, Carlier et al. (1992) encontraram resultados interessantes em modelos experimentais comparando dois grupos de camundongos recém-nascidos, após inoculação com T. cruzi. Camundongos sem infecção congênita, nascidos de mães cronicamente infectadas, apresentaram uma taxa de mortalidade maior, após inoculação pelo T. cruzi, quando comparados com camundongos nascidos de mães não infectadas. Estes resultados sugerem uma diminuição na resistência dos animais nascidos de mães infectadas, indicando a possibilidade de uma interferência da soropositividade materna no sistema imune da prole. A possibilidade desses resultados serem decorrentes de fatores genéticos ficou excluída, uma vez que o experimento foi realizado com linhagens isogênicas de camundongos. Estudos observacionais, conduzidos experimentalmente, em recém-nascidos de mães cronicamente infectadas e não infectadas constituem-se tema de grande interesse e necessários para extrapolação destes resultados para a infecção congênita humana.

Raros foram os estudos delineados utilizando o método epidemiológico para avaliar fatores associados à transmissão congênita da doença de Chagas. Castilho \& Silva (1976), em estudo caso-controle, avaliaram a infecção pelo T. cruzi como fator de risco para baixo peso. Duzentos e quarenta e nove recém-nascidos de baixo peso e igual número de recém-nascidos a termo, controles, pareados por sexo, paridade e idade materna foram comparados em relação à soroprevalência de infecção pelo T. cruzi nas mães. Nesse estudo não se detectou associação estatisticamente significante entre baixo peso da criança e infecção materna. No entanto, os autores fazem uma avaliação crítica desses resultados considerando alguns aspectos metodológicos relativos ao delineamento do estudo.

Em outro trabalho, também retrospectivo, Mota et al. (1985) compararam a freqüência de perdas fetais entre mulheres infectadas e não infectadas, em área endêmica para doença de Chagas, em Castro Alves, Bahia. O resultado deste 
estudo mostrou que jovens infectadas (15-24 anos) apresentaram maior risco de perda fetal quando comparadas com mulheres de maior idade, não infectadas.

Azogue \& Darras (1991) conduziram um estudo de coorte na Bolívia, para avaliar o valor preditivo da presença de $\mathbf{T}$. cruzi na placenta como indicador de transmissão congênita. Os autores acompanharam três grupos de recém-nascidos de baixo peso, sendo o grupo exposto constituído de 35 recém-nascidos de mães soropositivas ao T. cruzi, com presença de parasita na placenta e com pesquisa de T. cruzi negativa no sangue do cordão umbilical. O primeiro grupo controle, de 30 recém-nascidos cujas mães também eram soropositivas, apresentava exame parasitológico negativo tanto na placenta como no sangue do cordão umbilical. Um segundo grupo controle foi formado por recém-nascidos de mães soronegativas e, igualmente ao anterior, com pesquisa de parasita negativa na placenta e cordão. Após acompanhamento por 30 dias, os autores observaram a positivação parasitária no sangue de todos os recém-nascidos do grupo exposto, enquanto nos grupos controles todos permaneceram negativos ao exame parasitológico. $\mathrm{O}$ resultado desse estudo mostrou que a infecção pelo T. cruzi na placenta apresentou um valor preditivo positivo de $100 \%$ no diagnóstico da infecção congênita do recém-nascido.

Testes sorológicos podem auxiliar no diagnóstico da infecção ou doença de Chagas congênita. No entanto, pode-se encontrar anticorpos transferidos passivamente de mães chagásicas para o soro de recém-nascidos isentos de infecção; esses anticorpos tendem a negativar na criança não infectada, diferentemente do que ocorre nos casos de infecção congênita. Nesta última situação a produção de anticorpos pela criança resulta na manutenção de positividade dos testes, e anticorpos IgM anti-T. cruzi podem ser detectados no soro do recém-nascido pela reação de imunofluorescência indireta. É importante ressaltar a possibilidade de falsos resultados. Fatores reumatóides podem estar presentes no soro de recémnascidos de mães chagásicas, porém não infectados pelo T. cruzi, conduzindo a testes falso-positivos. Quanto às causas de resultados falso-negativos, anticorpos IgM podem não ser detectados devido à competição pelos anticorpos IgG ou pela 
incapacidade de produção de anticorpos IgM anti-T. cruzi pelo recém-nascido (Bittencourt, 1976; Bittencourt, 1984b).

Desta forma, o método mais eficaz para o diagnóstico da infecção chagásica no recém-nascido é o parasitológico. Nas crianças menores de 6 meses, é também imprescindível o diagnóstico parasitológico, uma vez que reações sorológicas positivas podem apenas refletir a passagem passiva de anticorpos maternos, como já mencionado. Aliando simplicidade e rapidez, esse método é de fácil aplicação, e seus resultados imediatos permitem que se inicie precocemente o tratamento com o objetivo de evitar seqüelas.

Porém, como o exame direto pode dar resultados falso negativos, ele tem sido utilizado com prévio enriquecimento. Quando se dispõe de sangue do cordão umbilical, o melhor método para realizar esse exame é o enriquecimento em tubos de micro hematócrito. Esse método apresenta como vantagens o fato de ser inócuo, de baixo custo, execução rápida e resultado imediato. Além do que, por não utilizar punção venosa, pode ser facilmente executado em recém-nascido de baixo peso (Freilij et al., 1983; Bittencourt, 1985). Recentemente, Freilij et al. (1987) descreveram uma nova técnica para o diagnóstico da infecção congênita. Trata-se da reação imunoenzimática para pesquisa de antígenos parasitários, utilizando principalmente urina de recém-nascidos, com leitura espectrofotométrica. Os resultados iniciais mostraram alta sensibilidade no diagnóstico da doença de Chagas congênita.

Apesar do xenodiagnóstico apresentar alta sensibilidade para detecção de parasita na fase aguda da infecção, este exame, além de ser dispendioso e trabalhoso, apresenta também o inconveniente de fornecer resultados após 30 dias, sendo no entanto, útil em estudos de prevalência (Minter et al., 1978).

Pelo exposto, observam-se diferenças regionais não só em relação à frequiência de infecção pelo T. cruzi em recém-nascidos, como também em relação 
à gravidade da doença congênita. Resultados divergentes podem ser explicados por problemas metodológicos como o tamanho insuficiente do estudo, inconsistências entre hipótese a ser testada, objetivos e delineamento da investigação, além da variabilidade nas cepas em diferentes regiões e diferenças quanto à sensibilidade dos métodos diagnósticos utilizados. Estudos de incidência devem incluir, como variável dependente, todos os produtos da gestação, como recém-nascidos prematuros e óbitos intra-uterinos, na tentativa de evitar vício de seleção de participantes, que tem sido comum na avaliação da infecção congênita pelo $\mathbf{T}$. cruzi.

Finalmente, a infecção pelo T. cruzi em mulheres vem sendo motivo de preocupação e despontando como tema de grande interesse em anos recentes. Destacam-se os trabalhos de Guinsburg \& Kopelman (1989), Brabin (1992) e Brabin (1993). Esta última autora, em excelente revisão sobre a importância da infecção pelo T. cruzi em mulheres, alerta para a necessidade de um melhor conhecimento da relação entre infecção materna e estado imune da criança, tendo em vista a possibilidade da utilização de vacinas (Frasch et al., 1990) e terapêutica na grávida, no futuro.

\section{c. Transmissão transfusional}

Em 1950, Freitas et al. descreveram os primeiros casos de transmissão transfusional da doença de Chagas em São Paulo, após acompanhamento de indivíduos que receberam $y$ transfusão de sangue de doadores soropositivos para anticorpos anti-T. cruzi (Freitas et al., 1952). Nussenzweig et al. (1955), dando prosseguimento aos estudos de Freitas et al. (1952), comprovaram mais dois casos de transmissão por via sanguínea e, após estudos sobre a atividade tripānosomicida de corantes, verificaram aparente esterilização do sangue com adição de violeta de genciana a 1:4000, após 24 ou 48 horas em geladeira. Desta forma, os autores estabeleceram as bases para a quimioprofilaxia do sangue suspeito de infecção (Nussenzweig et al., 1953). 
No Brasil, a prevalência de infecção pelo T. cruzi em doadores de sangue varia de acordo com a região, com relato de taxas de até $25 \%$, detectadas em Goiânia (Schlemper Jr, 1978). Assim, o risco de transmissão por via transfusional varia de acordo com a região. Em estudos de acompanhamento de pacientes que receberam transfusão de sangue de pacientes chagásicos, a transmissão de $\mathbf{T}$. cruzi ocorreu em 18,5\% (Nussensweig et al., 1955), em 13,0\% (Salazar et al., 1962) e em 14,3\% (Coura, 1966). Na Bolívia, Zuna et al. (1985) acompanharam 30\% (21) dos receptores soronegativos que receberam transfusão de sangue infectado e verificaram uma incidência de infecção de 47,6\% (10/21) após 122 dias, comprovada por exame direto de parasitemia.

Várias características associadas ao T. cruzi parecem favorecer a transmissão via sangue, aliando-se a isto o fato de a infecção ser duradoura e clinicamente assintomática por muitos anos. Dias (1979) descreve que o risco de um receptor infectar-se a partir de uma única transfusão com sangue de doador chagásico varia de $12,5 \%$ a $25,0 \%$. Fatores relacionados à cepa do parasita, ao receptor, à quantidade de sangue transfundido, ao número de transfusões recebidas pelo paciente e à prevalência da infecção na área de estudo podem estar associados ao risco de transmissão transfusional (Dias, 1979). Por exemplo, pacientes hemofílicos constituem um grupo considerado de alto risco para aquisição de infecção pelo T. cruzi por via sanguínea devido às numerosas e freqüentes transfusões a que são submetidos, conforme observado por Cerisola et al. (1972).

Martelli et al. (1992) detectaram um risco de infecção 9,2 vezes maior para doadores que moraram por pelo menos duas décadas em áreas endêmicas, quando comparados com os que sempre moraram em centros urbanos. Primodoadores de sangue apresentaram um risco 2,5 vezes maior de estarem infectados quando comparados com doadores habituais.

Entre doadores de sangue habituais em áreas endêmicas, têm sido detectados indivíduos com sorologia positiva e xenodiagnóstico positivo (Bronfen \& Chiari, 
1988). Uma outra variável a ser considerada diz respeito à viabilidade e virulência do T. cruzi por 2 ou 3 semanas no sangue, plasma ou papa de hemácias estocadas (Cerisola et al., 1972).

Inicialmente, o controle da transmissão transfusional foi baseado em quimioterapia com violeta de genciana no sangue a ser transfundido (Nussensweig et al., 1953; Nussensweig et al., 1955). Esse corante foi amplamente empregado, durante muitos anos, antes da implementação da triagem sorológica nos bancos de sangue, na Argentina e no Brasil, especialmente nos Estados de Goiás e Minas Gerais (Rezende et al., 1965; Campos et al., 1975; Rassi \& Rezende, 1975; Souza et al., 1985). Esse procedimento de baixo custo mostrou-se efetivo, conforme verificado por Amato-Neto \& Mellone (1959). Esses autores adicionaram violeta de genciana a 1:2000 em sangue obtido de paciente na fase aguda da doença, 48 horas antes da transfusão e não verificaram infecção após 3 meses de seguimento do paciente. Em contrapartida, camundongos que receberam o mesmo sangue, porém sem o corante, tornaram-se infectados. Mais de 70 mil transfusões foram realizadas sem relato de transmissão de infecção ou efeitos colaterais, nas concentrações usuais de 1:4000 (Dias, 1987). No entanto, essa medida profilática não vem sendo mais empregada, sendo a triagem sorológica de doadores de sangue o método oficialmente recomendado pelo Ministério da Saúde para a prevenção pela transmissão do T. cruzi através de sangue e hemoderivados (Ministério da Saúde, 1989).

A reação de Guerreiro-Machado (1913) (vide próximo capítulo para detalhes) foi, até a década de 60 , a única técnica utilizada na triagem sorológica em doadores de sangue. No entanto, Rassi et al. (1969) chamaram a atenção para a ocorrência de resultados negativos, temporariamente, em pacientes chagásicos crônicos. Resultados semelhantes foram encontrados posteriormente por outros autores, que também verificaram resultados negativos e/ou discordantes obtidos pela reação de Guerreiro-Machado em pacientes comprovadamente chagásicos (Campos et al., 1975; Prata et al., 1976). Configurava-se, assim, o risco em potencial de 
transmissão quando essa técnica era a única utilizada, enfatizando-se a necessidade de se empregar mais de uma técnica sorológica em triagens de doadores de sangue. Desta forma, em 1969, a Comissão Nacional de Hemoterapia propôs normas gerais para triagem de doadores de sangue em relação à infecção chagásica e, em 1974, definiu os pré-requisitos mínimos para o funcionamento de bancos de sangue (Dias, 1987).

Apesar dessa legislação, transfusões de sangue ainda continuaram sendo feitas de forma inadequada, particularmente em pequenas comunidades do interior. Nessas localidades, onde ..os serviços de saúde são precários, sem pessoal especializado, as transfusões são geralmente feitas de emergência, a partir de doadores voluntários. Em investigação conduzida em municípios do Estado de Minas Gerais, Dias \& Brener (1984) encontraram que 42\% daqueles municípios realizavam transfusão de sangue e em apenas $40 \%$ deles o sangue era triado sorologicamente para detecção de anticorpos anti-T. cruzi. Aliado a esta baixa cobertura, cerca de $70 \%$ dos bancos de sangue empregavam apenas uma técnica sorológica.

Embora a triagem para doador de sangue infectado tenha sido introduzida no Brasil em 1969, somente após 1989, com a emergência da infecção pelo Virus da Imunodeficiência Humana, os bancos de sangue implementaram este procedimento, em conseqüência de intensa revisão da política de sangue e hemoderivados. Nesse período inicia-se a construção / implementação de hemocentros em todo país. Desta forma, o Ministério da Saúde (Portaria 721 de 9 de agosto de 1989) passou a recomendar que todo sangue de doador fosse submetido a triagem para anticorpos anti-T. cruzi mediante duas técnicas sorológicas pelo menos. Desde então, a hemaglutinação indireta (HAI) e a fixação de complemento (FC) têm sido as reações mais amplamente utilizadas pelos bancos de sangue da rede pública e privada para o sorodiagnóstico da infecção pelo T. cruzi. A reação de imunofluorescência indireta (IFI) tem sido utilizada para os resultados inconclusivos, pois necessita de pessoal treinado e microscópio de 
fluorescência, o que restringe o seu uso como procedimento de rotina em boa parte dos bancos de sangue (Andrade et al., 1989). Mais recentemente, a técnica de ELISA vem sendo incorporada aos serviços de rotina de alguns bancos de sangue, aumentando a sensibilidade na detecção de doadores soropositivos (Andrade et al., 1992a). O uso das diferentes técnicas sorológicas para detecção de infecção pelo T. cruzi será abordado no ítem 1.2.

Reconhece-se, hoje, que o potencial para transmissão por transfusão de sangue é consideravelmente maior do que a transmissão por vetores, uma vez que a população sob risco é composta de indivíduos residentes em áreas urbanas, que representam $70 \%$ da população do continente. Acresce-se o fato de que grande parte da população urbana é constituída de indivíduos migrantes da zona rural, que residiram durante as primeiras décadas de suas vidas em regiões endêmicas para doença de Chagas (Silva et al., 1979; Zicker, 1988). Goldbaum (1981), em inquérito sorológico realizado em 27081 trabalhadores urbanos do setor metalúrgico da grande São Paulo, detectou uma soroprevalência de 2,2\%, correspondendo a 591 indivíduos, dos quais $81,5 \%$ eram procedentes de zona rural.

O aumento da urbanização da América Latina durante as décadas de 70 e 80 , especialmente devido à migração rural-urbana, mudou o panorama da doença de Chagas, implicando em novo padrão epidemiológico. Desta forma a doença passa de um problema exclusivamente rural para um problema urbano, com transmissão ocorrendo de homem a homem através da transfusão de sangue, significando uma ameaça para áreas endêmicas e não endêmicas. Recentemente, dois casos de forma aguda de doença de Chagas foram descritos nos Estados Unidos e Canadá, em conseqüência de transfusão de sangue de doador assintomático, imigrante da América Latina e cronicamente infectado pelo T. cruzi (Grant et al., 1989; Nickerson et al., 1989). A ocorrência desses dois casos motivou um editorial no Annals of Internal Medicine, no mesmo ano, intitulado Is Trypanosoma cruzi a new threat to our blood supply? (Kirchhoff, 1989). 
Amato-Neto (1984) chamou a atenção para o perigo de difusão da doença de Chagas via transfusão de sangue, e, no mesmo ano, Dias \& Brener (1984) estimavam cerca de 10 a 20 mil novos casos de infecção a cada ano no Brasil, por essa via. Admite-se que a transmissão por transfusão de sangue é uma das maiores implicações da urbanização da doença de Chagas, sendo considerada como um mecanismo de transmissão do T. cruzi de difícil controle (Amato-Neto, 1988; Dias, 1983).

Zicker et al. (1989) detectaram 13\% de soroprevalência entre trabalhadores urbanos sem qualificação técnica, em Goiânia. Zicker et al. (1990b) e Martelli et al. (1992), estudando doadores de sangue da mesma cidade e mesmo período, mostraram que a maior parte destes indivíduos eram trabalhadores braçais, de baixo nível sócio-econômico e migrantes de áreas rurais onde a doença é endêmica. Ainda em Goiânia, Andrade et al. (1989) compararam os resultados obtidos pelo inquérito nacional de soroprevalência para infecção pelo T. cruzi, realizado em 1975, em municípios rurais de Goiás, com os obtidos em triagem sorológica de doadores de sangue. Os autores chamaram a atenção para a maior taxa de prevalência $(10,4 \%)$ detectada em doadores de sangue da cidade, enquanto, no mesmo ano, a prevalência detectada na zona rural fora de $7,4 \%$. Esses resultados mostram claramente a concentração de chagásicos na área urbana já na década de 70. Além do mais, $6 \%$ dos indivíduos residentes na cidade haviam doado sangue nos anos de 1986 e 1987 (Andrade et al., 1989).

Desta forma, a - transmissão do T. cruzi por transfusão de sangue vem adquirindo, sem dúvida, importância crescente na América Latina. A magnitude da transmissão pelo $\mathbf{T}$. cruzi por sangue infectado pode ser avaliada pela quantidade de trabalhos que vêm sendo realizados em bancos de sangue, nas décadas de $80 \mathrm{e}$ 90 (Souza et al., 1985; Bronfen \& Chiari, 1988; Souza, 1989; Brener, 1989; Carrasco et al., 1990; Zicker et al., 1990b; Martelli et al., 1992; Andrade et al., 1992a). 
Em somente cinco países da América Latina, Argentina, Brasil, Honduras, Uruguai e Venezuela, a triagem de doadores para infecção pelo T. cruzi é compulsória (Moncayo, 1992). Na Bolívia, Carrasco et al. (1990), como parte de uma investigação sistemática nos bancos de sangue de 7 localidades, detectaram prevalências de até $51 \%$ mostrando o grande risco de infecção por esta via. Aliado a estes achados, o problema adquire importância do ponto de vista de saúde pública naquele pais, onde a venda de sangue é um procedimento habitual e apenas uma pequena parcela dos bancos de sangue adotam medidas preventivas em relação à transmissão da infeç̧ão por sangue contaminado, quer seja adição de violeta de genciana quer seja triagem sorológica de doadores.

Conseqüentemente, a interrupção da transmissão transfusional do T. cruzi é considerada, hoje, o maior desafio e meta principal do Programa de Controle da doença de Chagas em áreas urbanas (Schmuñis et al., 1991). Mesmo em centros urbanos, onde são empregadas 2 técnicas sorológicas na triagem de doadores, existe o risco de transfusão de sangue infectado. Em estudo realizado recentemente em 6 bancos de sangue de Goiânia, foi verificado que em dois deles o critério de positividade utilizado baseava-se em altos pontos de corte, ocasionando resultados falso negativos (Andrade et al., 1992a). Esses resultados mostram a necessidade de se estabelecer um sistema de vigilância epidemiológica contínuo, para controle de qualidade de sangue e hemoderivados a nível nacional, incluindo investigação clínico-epidemiológica dos doadores soropositivos. 


\subsection{Soroepidemiologia da infecção pelo Trypanosoma cruzi}

A soroepidemiologia tem se constituído em método amplamente utilizado para o estudo de determinantes causais, especialmente no campo das doenças transmissíveis. Sua utilidade tem sido, entre outras, a comparação entre duas ou mais populações. Entretanto, em estudos de prevalência nos quais uma única amostra é coletada e os resultados apresentados de forma dicotômica, a escolha do ponto de corte pode ser crucial, sendo por vezes uma decisão arbitrária. Este valor dependerá da técnica utilizada, do objetivo do estudo e da distribuição de anticorpos na população.

A soroepidemiologia tem se mostrado útil no conhecimento do estado imunológico de grupos populacionais pela utilização de marcadores sorológicos de exposição atual e prévia a determinado agente infeccioso, respectivamente anticorpos da classe IgM e IgG. Segundo Rosenbaum \& Cerisola (1961), obtem-se informações sobre o que aconteceu no passado, com indivíduos estudados no presente, através de estudos de corte transversal. Na infecção pelo T. cruzi, o estudo destes marcadores, por faixa etária, é de extremo valor para o direcionamento de medidas de intervenção em saúde pública e mesmo para avaliar a efetividade de programas de controle de doenças endêmicas (Dias, 1967; Hoff et al., 1985; Chuit et al., 1989; Andrade et al., 1992b).

Várias reações sorológicas têm sido utilizadas no diagnóstico da infecção pelo T. cruzi. Os testes de imunofluorescência indireta (IFI), hemaglutinação indireta (HAI), ensaio imunoenzimático (ELISA) e reação de fixação de complemento (FC) são os mais freqüentemente realizados em procedimentos de rotina, muito embora outras técnicas estejam sendo testadas em caráter experimental.

A reação de $\mathrm{FC}$ foi o primeiro método sorológico para o diagnóstico da infecção, descrito por Guerreiro \& Machado em 1913, poucos anos após o 
isolamento do T.cruzi. Inicialmente, utilizava como antígeno extrato aquoso de baço de cães infectados, posteriormente substituído por extrato do parasita. Foi a única técnica disponível, por mais de 40 anos, empregada em inquéritos epidemiológicos, na confirmação sorológica de uma suspeita clínica de infecção pelo T.cruzi e em triagem de doadores em bancos de sangue até a década de 60 . No entanto, os métodos empregados na preparação de antígenos e os procedimentos técnicos na condução da reação podem variar de acordo com o laboratório, o que dificulta a comparabilidade de resultados interlaboratórios (Prata et al., 1976). Por esta razão, a reação de FC foi motivo de diversas propostas de padronizações de reagentes, sendo a efetuada por Almeida \& Fife a mais completa, servindo de referência após sua publicação pela Organização Panamericana de Saúde. Nessa publicação, descreve-se com detalhes procedimentos para padronização de extratos antigênicos do T.cruzi, pela técnica de fixação do complemento, utilizando-se um ponto final de hemólise de $50 \%$ para a padronização do complemento. Este estudo resultou na produção de um soro de referência, produto liofilizado, podendo ser fornecido a pesquisadores ou laboratórios interessados (Almeida \& Fife, 1976). Apesar de sua relativa complexidade, a reação de FC apresenta uma especificidade e sensibilidade adequadas, especialmente quando se adota a técnica de $50 \%$ de hemólise (Knierin, 1958). No entanto, por ser um método que envolve vários reagentes que requerem estrito controle de qualidade, difícil de se obter em rotina de laboratório (Baruffa \& Alcântara Filho, 1975; Prata et al., 1976), a reação de FC tem sido substituída pelas técnicas de HAI e IFI, ambas de maior simplicidade para diagnóstico de rotina em laboratórios.

A técnica de hemaglutinação indireta foi descrita por Cerisola et al., em 1962, e consiste basicamente na ligação de antígenos de T.cruzi a hemácias tratadas por ácido tânico (Cerisola et al., 1962). Várias modificações técnicas posteriores permitiram obter lotes de antígeno com reatividade similar, produzidos comercialmente em kits, evitando assim diferenças significativas entre lotes. $\mathrm{O}$ seu desempenho em relação a sua especificidade e sensibilidade é comparável ao da fixação de complemento e ao da imunofluorescência indireta (Cerisola et al., 1970, 
Camargo \& Takeda, 1979). Com a utilização de kits esta técnica é a de mais fácil execução, com leitura de resultados em prazo relativamente curto. Como desvantagem, apresenta custos elevados, se obtida comercialmente.

A reação de IFI descrita inicialmente por Fife \& Muschel em 1959 foi difundida após as modificações introduzidas por Camargo em 1966 (Fife \& Muschel, 1959; Camargo, 1966). Consiste no emprego de parasitas, provenientes de cultivo, fixados em lâminas, delimitados por relevos nas mesmas. Os soros são incubados com os parasitas fixados, lavados e incubados com anti-soro anti-Ig humano conjugado com isotiocianato de fluoresceína. Após lavagem, as lâminas são montadas com glicerina tamponada e lamínula e os parasitas são visualizados no microscópio, observando-se, com ultravioleta, a presença de fluoresceína nos trypanosomas, o quê indica soro positivo na diluição empregada. Apresenta como vantagem a simplicidade de execução, dispensando processos de extração ou de fracionamento para obtenção de antígenos. É de custo mais acessível quando comparada à HAI, além de permitir o processamento de grande número de amostras simultaneamente. Porém requer microscópio de fluorescência, a leitura é subjetiva, especialmente nos resultados limítrofes, podendo ocorrer reações cruzadas com outras doenças parasitárias, como por exemplo leishmanioses (Camargo \& Rebonato, 1969).

Em 1975, Voller introduziu a técnica de ELISA (Voller et al., 1975), o que, sem dúvida, contribuiu para o aperfeiçoamento do diagnóstico da infecção pelo $T$. cruzi. Altos índices de sensibilidade são obtidos, no entanto o ponto de corte para positividade deve ser ajustado para cada placa e cada experimento, para facilitar a interpretação de resultados duvidosos (Zicker et al., 1990d). Kits comerciais de ELISA têm sido testados com soros de pacientes chagásicos, não chagásicos e com outras doenças parasitárias, obtendo-se altos índices de sensibilidade e especificidade, mostrando a aplicabilidade desta técnica em triagens de doadores de sangue e na confirmação do diagnóstico clínico (Ferreira et al., 1991; Pan et al., 1992). 
Camargo et al. (1986) mostraram as dificuldades na padronização de técnicas para o sorodiagnóstico da doença de Chagas. Embora vários testes sorológicos estejam disponíveis, diferenças nos procedimentos técnicos, reagentes utilizados, pessoal treinado, contribuem para as discrepâncias entre resultados obtidos interlaboratórios e mesmo intralaboratórios, acarretando baixos índices de reprodutibilidade e confiabilidade. A escolha do teste geralmente depende da preferência do laboratório em termos de disponibilidade de equipamentos, reagentes e pessoal. Considerando que a especificidade dos testes pode variar consideravelmente, os pontos de corte para positividade devem ser definidos localmente, usando um painel de soros padrão (Camargo et al., 1986; HoshinoShimizu et al., 1986). Todos estes aspectos foram descritos em detalhe por Guimarães et al. (1987), em revisão sobre as normas para a sorologia de moléstias parasitárias. Neste sentido, aspectos relativos à padronização de técnicas sorológicas têm sido discutidos, enfatizando-se a necessidade de se desenvolver novos métodos e estabelecer uma rede nacional de laboratórios para assegurar o controle de qualidade (Camargo et al., 1986; Luquetti, 1990; Moncayo \& Luquetti, 1990).

A escolha do método sorológico a ser utilizado depende do objetivo da investigação. Em triagens de banco de sangue, o principal objetivo é excluir todo sangue potencialmente infectado e, nessas circunstâncias, necessita-se de testes com alta sensibilidade, sendo a especificidade de menor importância. Além da utilização de mais de uma técnica, em paralelo, para aumentar a sensibilidade da triagem, pontos de corte mais baixos devem ser selecionados para definição de positividade, a fim de se excluir todos os resultados duvidosos (Galen \& Gambino, 1975).

Por outro lado, para finalidades clínicas, fazem-se necessários testes não apenas sensíveis como também específicos. Para confirmação de diagnósticos clínicos, a especificidade do teste passa a ser requisito mais importante, uma vez que resultados falso positivos causam sérias implicações pelos problemas pessoais e também discriminações sociais ocasionados com tanta frequiência aos portadores 
de resultados sorológicos positivos (Camargo, 1972).

Em situações de seguimento de pacientes submetidos a terapêutica, todas as técnicas disponíveis devem ser utilizadas, principalmente quando o critério de cura baseia-se na negativação da sorologia. Testes com alta especificidade e alta sensibilidade são recomendados.

Em inquéritos sorológicos populacionais, testes com alta sensibilidade devem ser utilizados, levando-se em conta a provável baixa prevalência de infecção na população em geral. Devido ao grande volume de amostras a serem testadas, aliado às dificuldades inerentes ao trabalho de campo, incluindo pessoal, transporte $\mathrm{e}$ custo, recomenda-se que a coleta seja realizada por punção digital e o armazenamento em papel de filtro (Camargo et al., 1984; Guimarães et al., 1986).

Para avaliação da infecção pelo T. cruzi, os inquéritos são, em geral, realizados em conglomerados onde já se conhece que a doença é prevalente, ou em painéis de soros, definidos em laboratório (Anthony et al., 1979; Fuchs et al., 1980; Breniere et al., 1985). Em ambas as situações, o valor preditivo do teste sorológico utilizado pode ser superestimado em função de prevalências aumentadas (Galen \& Gambino, 1975; Guimarães, 1985). Poucos estudos têm avaliado a eficiência dos testes mais amplamente utilizados, em triagens populacionais. Zicker et al. (1990d) triaram sorologicamente 6.222 trabalhadores urbanos da cidade de Goiânia, comparando os resultados obtidos pelas técnicas de IFI, HAI e ELISA em eluato de papel de filtro e em sangue obtido por punção venosa. Naquele estudo, sensibilidade, especificidade e valores preditivos foram calculados ajustando-se por uma amostra de soropositivos e soronegativos da população triada, com o objetivo de predizer a validade dos testes em situações de campo. Esta análise de dados tipo caso-controle levou em conta a prevalência de infecção na população e detectou resultados limítrofes em $4,1 \%$ das amostras para IFI, em $2,9 \%$ para HAI e em 1,3\% para a técnica de ELISA. A sensibilidade dos testes no eluato foi $78 \%, 69 \%$ e $65 \%$, respectivamente para ELISA, IFI e HAI, mostrando ser a 
técnica de ELISA, em coleta de papel de filtro, um eficiente método para pesquisas populacionais.

Em área urbana, triagem sorológica populacional tem sido utilizada para seleção de participantes de estudo caso-controle para detecção de fatores de risco para infecção pelo T.cruzi e, também, fatores prognósticos para o desenvolvimento de cardiopatia chagásica. Indivíduos soropositivos e soronegativos para infecção pelo T.cruzi foram inicialmente selecionados por coleta de sangue em papel de filtro. Todos os indivíduos soropositivos e um percentual de soronegativos foram retestados utilizando-se sangue colhido por punção venosa. Indivíduos soropositivos e soronegativos confirmados na retestagem foram submetidos a eletrocardiograma (ECG). Os indivíduos soropositivos e com ECG compatível com cardiopatia chagásica foram definidos como casos e dois controles, pareados por sexo e idade, foram selecionados: a) indivíduos soronegativos e b) indivíduos soropositivos, ambos sem alterações ECG (Zicker et al., 1990c). Quando indivíduos soronegativos foram analisados como controles (a), o estudo avaliou riscos de desenvolvimento de doença de Chagas, de qualquer gravidade. Selecionando-se o segundo tipo de controle (b), o estudo determinou fatores de risco prognóstico associados à evolução da infecção para doença. Observa-se neste delineamento que tanto indivíduos soronegativos como soropositivos foram selecionados como controles, dependendo da questão que o estudo pretendia responder.

O maior inquérito populacional realizado no Brasil foi conduzido no período de 1975-1981, como parte de um programa integrado do Conselho Nacional de Desenvolvimento Científico e Tecnológico/CNPq e Ministério da Saúde. O estudo incluiu todas as áreas rurais do país, à exceção do Distrito Federal e São Paulo. Uma rede de laboratórios locais foi constituída, composta de universidades e serviços de saúde, sob a coordenação do Instituto de Medicina Tropical de São Paulo, que forneceu antígenos, soros padronizados e retestou $10 \%$ a $15 \%$ das amostras testadas em cada laboratório local, para fins de controle de qualidade. Em Goiás, dos 233 municípios, 219 foram incluídos, envolvendo uma população de 
os resultados dos laboratórios da Argentina, Brasil, Colômbia e Estados Unidos com os de um laboratório de referência. Altos índices de concordância e validade foram obtidos com grande parte dos antígenos testados, resultados promissores em relação a comercialização de kits para uso em triagens de doadores de sangue (Moncayo \& Luquetti, 1990). Por este motivo, ultimamente, um grande número de pesquisas vêm sendo desenvolvidas no campo dos antígenos recombinantes no diagnóstico da doença de Chagas. Este método tem mostrado ser uma boa opção em triagens de doadores de sangue devido à alta sensibilidade e especificidade detectadas nesse grupo de indivíduos. Apresenta também, como vantagem, um menor custo e maior segurança na produção de antígenos quando comparado aos antígenos isolados de culturas de parasitas (Krieger et al., 1992).

ELISA competitivo, empregando anticorpos monoclonais (Cuna et al., 1989) para identificação de cepas de T. cruzi (Bongertz \& Carvalho, 1992) e dotELISA (Hubsch et al., 1989) também vem sendo pesquisado.

A técnica de DOT-imunoensaio para detecção de exo-antígenos solúveis do T. cruzi tem mostrado alta sensibilidade e especificidade em estudos realizados em recém-nascidos com infecção congênita e em camundongos infectados experimentalmente, apresentando-se desta forma, como opção alternativa ao uso do xenodiagnóstico (Corral et al., 1992).

Petray et al. (1992) realizaram uma investigação em população endêmica, na Argentina, para avaliação de marcadores antigênicos na infecção pelo T. cruzi. Maiores sensibilidades da técnica de ELISA para deteção de antígenos e imunocomplexos circulantes foram encontradas quando comparada com o diagnóstico parasitológico clássico, permitindo diagnosticar parasitas de pacientes cronicamente infectados, achado esse de contribuição para o entendimento da história natural da infecção pelo T. cruzi.

Recentemente, tentativas têm sido feitas para detecção do parasita através do 
DNA, utilizando-se a reação da polimerase em cadeia-PCR, em experimentos com animais de laboratório (Diaz et al., 1992). No entanto essa técnica ainda necessita ser aperfeiçoada, devido à baixa sensibilidade mostrada até o momento e à obtenção de resultados falso negativos. Por tratar-se de método laborioso e de custo elevado deverá ter uso restrito, não sendo apropriada para triagens populacionais.

Para avaliar a exatidão de uma técnica sorológica tem-se utilizado, classicamente, os indicadores de validade, que medem a sensibilidade e especificidade do teste, quando comparado com o diagnóstico de certeza da doença (Fletcher et al., 1983). Quando não se dispõe de um diagnóstico que comprove a doença, a comparação é feita utilizando-se um teste de referência como valor de diagnóstico, calculando-se a sensibilidade relativa ou co-positividade e a especificidade relativa ou co-negatividade (Buck \& Gart, 1966; Camargo et al., 1977; Breniere et al., 1985; Carrasco et al., 1985; Hubsch et al., 1989; Andrade et al., 1992a).

No contexto epidemiológico, a validade de um marcador sorológico diz respeito à extensão com que ele pode predizer a ocorrência da doença/infecção. Nessas circunstâncias, a questão a ser respondida é: dado que o teste apresentou resultado positivo, qual a probabilidade do indivíduo ser realmente doente? Esse atributo do teste é conhecido como valor preditivo (VP), podendo ser positivo (VPP) ou negativo (VPN), e é determinado pela interação de três variáveis: a sensibilidade, e a especificidade do teste e a prevalência da doença no grupo estudado (Galen \& Gambino, 1975). Zicker et al. (1990d) calcularam os valores preditivos positivos da IFI, HAI e ELISA no eluato, tendo como referência resultados desses testes em sangue venoso. Um decréscimo importante do VPP foi detectado quando o critério de positividade passou de dois para três testes positivos, resultando em diminuição da prevalência de indivíduos positivos ao T. cruzi na população estudada.

A estatística kappa (Fleiss, 1981) tem sido utilizada para comparar resultados 
obtidos por diferentes técnicas ou pela mesma técnica por diferentes laboratórios, quando o diagnóstico de certeza não está disponível (Moncayo \& Luquetti, 1990; Andrade et al., 1992a). O índice kappa depende da sensibilidade, da especificidade e também da prevalência da doença na amostra estudada (Spitznagel \& Helzer, 1985; Thompson \& Walter, 1988), sendo que altos níveis de repetibilidade não significam necessariamente validade, pois os resultados podem ser consistentemente errados. Este índice de concordância apresenta como vantagem a correção por acaso em seu cálculo, embora reconheçam-se dificuldades na interpretação dos resultados (Maclure \& Willet, 1987; Seigel et al., 1992). Porém as dificuldades em se interpretar um índice global de concordância podem ser minimizadas quando dois componentes separados do índice kappa, concordância de positivos e concordância de negativos, são calculados (Feinstein \& Cicchetti, 1990). Esta estratégia tem permitido um melhor entendimento e interpretação dos resultados, em analogia com os indicadores de validade, sensibilidade e especificidade (Thompson \& Walter, 1988; Cicchetti \& Feinstein, 1990; Lombardi et al., 1993).

Recentemente, outras abordagens interessantes têm sido propostas para o uso dos indicadores de validade e de concordância. Destacam-se o uso da estatística kappa para o cálculo da concordância em estudos caso-controle pareados (Kraemer \& Bloch, 1988; Thompson \& Walter, 1988) e a utilização da sensibilidade e especificidade também corrigidas para o acaso à semelhança do índice kappa (Coughlin \& Pickle, 1992).

Pelo exposto, verifica-se que a soroepidemiologia pode fortalecer a pesquisa epidemiológica e auxiliar na aquisição de novos conhecimentos sobre saúde e doença entre grupos de indivíduos. Alta especificidade tanto da variável definidora de doente/não doente como da variável exposição é requisito indispensável no delineamento de estudos tipo caso-controle. Neste contexto, a definição de doente/infectado (caso) e sadio (controle) seria equivalente, respectivamente, a um painel de controles positivos e um painel de controles-negativos possibilitando o cálculo, por exemplo, da sensibilidade das variáveis de exposição na detecção de 
casos. Da mesma forma, o valor preditivo positivo da variável de exposição poderá ser avaliado.

\subsection{Indicadores epidemiológicos de vigilância e controle}

Os programas de controle para doença de Chagas foram implementados a partir da década de 60 na Argentina e no Brasil, com uso de inseticidas. Na Venezuela, a melhoria das habitações foi também oficialmente incluída no programa, como estratégia de controle (WHO, 1991c). Na Argentina, o número de casos agudos tem diminuído desde 1970 e a soropositividade em homens de 18 anos tem decrescido significantemente desde 1980 (Segura et al., 1985). Resultados entomológicos, sorológicos e de detecção de casos, após 20 anos de programa, têm mostrado um decréscimo das taxas de soropositividade na Venezuela (Acquatella et al., 1987).

No Brasil, até 1980 , os recursos financeiros eram escassos e as atividades de borrifação com inseticidas sem continuidade. No entanto, o Estado de São Paulo, através de um programa consistente e contínuo iniciado nos anos 60, alcançou resultados excelentes em 1975, com a interrupção da transmissão por vetores, com mais de $70 \%$ dos municípios negativos para o T. infestans (Souza et al., 1984). Na maior parte dos municípios do Brasil, a fase de ataque com inseticidas teve início em 1983, objetivando a cobertura de 2400 localidades de áreas endêmicas. Os resultados entomológicos obtidos mostraram-se animadores em cerca de $70 \%$ das áreas incluídas no programa, com redução drástica da endemia (Dias, 1987). Esses municípios encontram-se atualmente na fase de vigilância do programa, com borrifação seletiva das moradias (Dias, 1991).

Para avaliação das atividades de controle do programa de doença de Chagas, a Organização Mundial da Saúde recomenda que se încluam indicadores 
entomológicos e sorológicos e avaliação clínica. Esses indicadores fornecem subsídios para medir a duração do efeito do programa, determinando com que frequêencia medidas específicas devem ser adotadas. Indicadores que relacionam a comunidade e os métodos de vigilância e a dinâmica da moradia e infestação triatomínica também têm sido descritos, apesar de pouco utilizados (WHO, 1991c).

Neste Capitulo são revisados os indicadores entomológicos, sorológicos e os métodos que incorporam a participação da comunidade no processo de vigilância $\mathrm{e}$ controle da transmissão do T. cruzi.

\section{a. Indicadores entomológicos}

De acordo com a Organização Panamericana da Saúde, os seguintes indicadores são utilizados para vigilância de vetores (OPS, 1978):

- índice de infestação de triatomíneos:

$100 \times\left(\mathrm{n}^{\circ}\right.$ casas infestadas por triatomíneos $/ \mathrm{n}^{\circ}$ casas examinadas) $\%$

- índice de densidade:

$\mathrm{n}^{\circ}$ de triatomíneos capturados $/ \mathrm{n}^{\circ}$ de casas examinadas

- índice de dispersão:

$100 \times\left(\mathrm{n}^{\circ}\right.$ de localidades infestadas/ $\mathrm{n}^{\circ}$ de localidades examinadas) $\%$

- índice de população:

$\mathrm{n}^{\circ}$ triatomíneos capturados $/ \mathrm{n}^{\circ}$. de casas com triatomíneos

- índice de colonização:

$100 \times\left(\mathrm{n}^{\circ}\right.$ casas com ninfas $/ \mathrm{n}^{\circ}$ de casas com triatomíneos) $\%$

- índice de infecção dos triatomíneos:

$100 \times$ ( $\mathrm{n}^{\circ}$ triatomíneos com $\mathbf{T}$. cruzi $/ \mathrm{n}^{\circ}$ triatomíneos examinados) $\%$

Os métodos de avaliação entomológica podem ser ativos ou passivos. Os métodos ativos baseiam-se na captura de triatomíneos pela inspecção de casas por coletadores treinados que investigam todos os possíveis locais de refúgio, dentro da 
moradia e no ambiente peridoméstico, por um período de tempo fixo, em geral uma hora. Essa busca ativa é conduzida com auxílio de substâncias piretróides, que funcionam como desalojantes dos triatomíneos devido ao poder irritante desses agentes.

Como método de captura passiva caixas sensores foram desenvolvidas na Venezuela (Gómez-Núñez) e Argentina (Maria box). Estas caixas, colocadas nas paredes, são confeccionadas em cartolinas contendo perfurações nas laterais, permitindo a entrada de barbeiros para servir de esconderijo artificial. A presença de barbeiros ou vestígios, tais como exúvia, fezes ou ovos é informada às autoridades de saúde local (Gómez-Núñez, 1965; Wisnivesky-Colli et al., 1987). Periodicamente, técnicos do programa de controle ou o próprio morador encarregam-se da entrega desse material ao centro de referência mais próximo, quer seja posto de saúde, escola ou posto da Fundação Nacional de Saúde. A participação comunitária no processo de detecção de triatomíneos significa uma vigilância continuada, em contraposição às atividades verticais, de captura de vetores realizadas por técnicos do programa de controle. De acordo com Dias (1991), essas intervenções verticais, realizadas anualmente, além de onerosas, são pouco sensíveis para detecção de triatomíneos especialmemte em casas com baixa densidade de vetores ou que se tornaram infestadas após a inspecção da moradia.

Schofield (1978), comparando métodos ativos e passivos de detecção de triatomíneos no domicílio, verificou baixa reprodutibilidade da estimativa de infestação pelo método de captura manual homem-hora, pois os resultados variavam de acordo com a experiência prévia do coletador. Por outro lado, o método de Gómez-Núñez mostrou alta sensibilidade para detecção de casas infestadas, sendo de grande utilidade para o monitoramento contínuo de casas onde a população de vetores encontra-se reduzida devido às aplicações de inseticidas.

Estudos conduzidos na Argentina, comparando a sensibilidade dos métodos ativo e passivo, mostraram que o método Maria box foi mais sensivel que o método 
de Gómez-Núñez e tão efetivo quanto o método de captura manual homem-hora (Wisnivesky-Colli et al., 1987). Posteriormente, este método também mostrou-se mais sensível para detecção de triatomíneos após a fase de ataque com inseticida em uma área endêmica da Argentina, quando comparado ao método convencional de captura manual. Desta forma, a vantagem do método Maria box seria a possibilidade de detectar não só triatomíneos, mas, também, vestígios de vetores, o que adquire importância fundamental em áreas de baixa densidade de vetores (Chuit et al., 1992).

Vale ressaltar que comparações entre diferentes áreas rurais, mesmo entre municípios vizinhos, devem ser feitas com cautela, pois vários aspectos devem ser levados em conta. Características gerais da população, cepas predominantes na região, densidade de vetores e particularmente intervenções ocorridas nos últimos anos, são alguns dos aspectos que devem ser levados em conta quando se compara o padrão epidemiológico de diferentes regiões do país. Para o Estado de São Paulo, além da efetividade do programa de controle de vetores, transformações do espaço geográfico com extenso desmatamento, implementação de indústrias com deslocamentos de trabalhadores rurais para centros urbanos, agricultura extensa e mecanizada e formação de pastagens, foram fatores que certamente também influiram para o controle dos triatomíneos (Dias, 1988; Litvoc et al., 1990). Por outro lado, na área de estudo, foi mostrado, através de estudo de soroprevalência, que a transmissão do T. cruzi ainda ocorre, embora no município vizinho de Mambaí a infestação de casas pelo Triatoma infestans tenha atingido valores igual a zero durante o período de 1985 a 1988 (Garcia-Zapata \& Marsden, 1992), acompanhada pela ausência de casos incidentes de infecção em crianças de 1-4 anos (Dias, 1991). No entanto, deve-se considerar a situação especial do município de Mambaí, que vem sendo sede de estudos sobre doença de Chagas e conseqüentemente submetido à vigilância de vetores com intensa borrifação seletiva das moradias nos últimos dez anos.

No Estado de São Paulo, a fase de vigilância de vetores integrou-se ao 
programa de assistência primária à saúde desde 1984. A notificação de triatomíneos pela população mostrou ser um método eficiente de triagem prévia das casas a serem pesquisadas, aumentando a probabilidade de deteç̧ão de casa infestada. Em estudo conduzido por Wanderley (1991), 85,6\% dos triatomíneos capturados no intradomicílio foram devidos à notificação, ou seja, foram encaminhados pelo morador.

b. Indicadores sorológicos relacionados com a transmissão do Trypanosoma cruzi

A despeito da óbvia utilidade da avaliação entomológica para o controle de vetores, deve-se lembrar que o objetivo final do controle é reduzir a transmissão, que pode ser avaliada por estudos de soroprevalência que são operacionalmente mais práticos e de custo acessível quando comparados com a avaliação entomológica.

O uso de triagem sorológica, com objetivo de vigilância da transmissão do T. cruzi, tem sido recomendado como um componente integral do programa de controle da doença de Chagas para monitorar infestações residuais do vetor (Hoff et al., 1985). Neste sentido, crianças e doadores de sangue têm sido utilizados como populações sentinelas, respectivamente na zona rural e urbana, para medir o impacto do programa de controle da doença de Chagas. Estudos de tendência de soroprevalência em crianças têm indicado a interrupção da transmissão do T. cruzi, resultante do sucesso do programa de controle de vetores em alguns estados do Brasil (Souza et al., 1984; Dias, 1991). A soropositividade de crianças até 6 anos é um indicador sensível para detectar transmissão recente, enquanto tendências na prevalência de sorologia positiva em doadores de sangue é um indicador indireto da interrupção ou reinstalação da transmissão. No entanto, embora a triagem sorológica de crianças abaixo de seis anos pudesse fornecer informações mais precisas sobre o impacto do programa, uma vez que casos incidentes poderiam ser detectados, a condução de tal investigação seria dificultada por problemas de ordem logística. Em 1967, Dias, estudando sorologicamente 579 crianças em Bambui, 
Minas Gerais, verificou que o grupo de 1-6 anos, nascido após a campanha de combate aos triatomíneos com inseticidas, apresentou menor incidência de infecção pelo T. cruzi (1,3\%) quando comparado ao grupo de 7-13 anos, composto por crianças nascidas antes da campanha, com prevalência de 11,3\%. Diante desses resultados o autor concluiu que houve um benefício efetivo e satisfatório dos trabalhos de destriatomização realizados naquela região (Dias, 1967).

Resultados de soroprevalência de escolares foram utilizados para avaliação do programa de controle de vetores no Estado de São Paulo, em artigo de revisão publicado por Souza et al. (1984); O estudo da tendência de soroprevalência iniciado em 1975 mostrou que a infecção chagásica decresceu gradualmente a partir de 1982. Esses achados mostraram a efetividade do controle de vetores alcançada pelo programa de doença de Chagas no Estado de São Paulo, o que foi possível devido ao envolvimento da comunidade, no processo de notificação de triatomíneos (Souza et al., 1984).

Em Goiás, resultados de estudo de triagem sorológica em 1.990 escolares de área rural mostraram redução de prevalência de $23 \%$ para $7,9 \%$ na última década, provavelmente relacionada ao controle de vetores. Assim, os autores sugeriram a incorporação da triagem sorológica de escolares no programa de controle de vetores como estratégia para vigilância da transmissão do T. cruzi (Andrade et al., 1992b). De acordo com esses autores, a triagem sorológica de crianças no momento do ingresso na escola por amostragem aleatória das escolas rurais, a cada 4-5 anos, permitiria uma avaliação confiável do impacto do programa de controle da doença de Chagas. O número de escolas e crianças a serem investigadas dependeria da prevalência de infecção na área sob vigilância. Um tamanho de amostra de cerca de 1.000 escolares seria suficiente para estimar prevalências da ordem de $2 \%$ (LC $95 \%$ 1,1-2,8), o que seria aplicável à maioria das áreas endêmicas. A vigilância da transmissão do T. cruzi através de triagem sorológica de escolares seria útil para mapeamento de padrōes de morbidade e para detectar mudanças nas tendências, o que permitiria a comparação entre regiões. $O$ 
decréscimo na incidência da infecção pelo T. cruzi detectado através de estudos de prevalência pode refletir a eficácia das medidas de combate ao vetor. Porém, transformações ocorridas no meio ambiente devem também ser levadas em consideração quando se avalia o impacto dos programas de controle. Hoje, o desafio a ser enfrentado é obter um sistema acessível de vigilância, dentro do programa de controle de vetores que inclua ambas as avaliações, sorológica e entomológica.

Para avaliação do programa de controle da doença de Chagas na Venezuela, um inquérito sorológico foi realizado de 1981 a 1984, e os resultados comparados com os de 1961 a 1963 , período anterior ao programa de controle. As taxas de soropositividade em crianças menores de 10 anos decresceram para valores de $0,2 \%$ em relação à prevalência de $18,2 \%$ detectada anteriormente ao programa de controle (Acquatella et al., 1987).

Inquérito nacional de soroprevalência para infecção pelo T. cruzi, realizado no Uruguai, não mostrou soropositividade em escolares de 12 anos em cinco de treze estados, revelando ausência de transmissão vetorial do T. cruzi em indivíduos dessa idade. Estes achados foram de importância para direcionar medidas de controle para os demais estados assim como auxiliar no planejamento de programas de atenção médica, considerando que $4 \%$ da população estudada estava infectada (Salvatella et al., 1989).

Chuit et al. (1989) utilizaram a sorologia para avaliar o efeito de intervenções com inseticida, na transmissão da doença de Chagas na Argentina. Os autores compararam os resultados de soroprevalência de infecção pelo T. cruzi obtidos de treze comunidades rurais de províncias da Argentina, seis sem antecedentes de borrifação com inseticida e sete que haviam recebido tratamento esporádico ou contínuo. Cerca de $20 \%$ das moradias habitadas foram selecionadas aleatoriamente, com um total de 2.226 amostras de sangue de indivíduos de ambos os sexos, de 6 meses a 93 anos. Nas áreas submetidas a inseticida, a 
soroprevalência em crianças até 4 anos de idade foi $2,6 \%$, enquanto nas áreas sem tratamento prévio com inseticidas $17,5 \%$ de soropositividade foi detectada.

Para finalidade de vigilância, a utilização de apenas um teste sorológico pode ser suficiente, em estudos populacionais. O custo unitário de cada teste, levando em conta pessoal técnico/hora e material, tem sido estimado, em média, em um dolar, independentemente do método (OPS, 1991). Porém não existe uma indicação formal em relação ao uso de um teste sorológico específico para vigilância da infecção e a escolha do melhor teste deverá levar em conta as facilidades e experiência prévia dos laboratórios de cada região. Por exemplo, para a região de Goiânia, uma triagem populacional conduzida em mais de 6.000 trabalhadores urbanos, comparando 3 técnicas, indicou que o teste de ELISA coletado em papel de filtro é adequado para inquéritos populacionais, levando em conta a sensibilidade da técnica, aliada à relação custo/benefício (Zicker et al., 1990d).

Estudos seccionais de soroprevalência têm sido utilizados para avaliação de tendências da infecção pelo T. cruzi em doadores de sangue. Andrade et al. (1989) discutiram a utilização de dados secundários de prevalência de anticorpos anti-T. cruzi obtidos em bancos de sangue, como indicador de morbidade populacional. Resultados obtidos para as décadas de 70 e 80 , respectivamente $10,4 \%$ e $3,3 \%$, sugeriram diferenças na proporção de imigrantes rurais para áreas urbanas e/ou melhoria do controle de vetores, o que estaria ocasionando um efeito coorte, ambos aspectos também descritos por Zicker et al. (1990b). Os autores enfatizam as seguintes vantagens desta triagem sorológica: a) é o único dado estatístico de morbidade para a doença de Chagas coletado rotineiramente e com baixo custo; b) é procedimento de alta sensibilidade para deteç̧ão de soropositivos devido ao baixo ponto de corte utilizado; c) amostra composta, em grande parte, por indivíduos migrantes de zona rural, espelhando a transmissão em áreas endêmicas; d) possibilidade de inferências populacionais com finalidades de planejamento e organização de serviços de saúde pública para atenção ao chagásico em área urbana. No entanto, para inferências populacionais, devemos levar em 
conta que cerca de $90 \%$ da população de doadores é constituída de indivíduos do sexo masculino, adultos (Andrade et al., 1989). O uso da triagem sorológica realizada pelos bancos de sangue, como fonte de informação epidemiológica para monitorar tendências da infecção pelo $\mathbf{T}$. cruzi em população adulta, também foi recomendada por Zicker, et al. (1990b) ao investigar 1.358 primodoadores de sangue de Goiânia.

Martelli et al. (1991) chamam atenção para o fato de que estimativas de prevalência baseadas em doadores podem subestimar o nível de infecção populacional. Neste sentido, o ato de doação poderia estar relacionado a uma consciência de saúde, o que ocasionaria um efeito do doador saudável, em analogia ao healthy worker effect, descrito em estudos de mortalidade entre trabalhadores. Ainda os mesmos autores advertem que, para finalidade de monitoramento, a análise dos dados deve incluir apenas indivíduos primodoadores, identificando-se a procedência dos mesmos. A inclusão de doadores regulares, que em determinadas regiões representam $75 \%$ dos candidatos a doador, introduziria vício de seleção, subestimando os resultados de soropositividade, uma vez que esses indivíduos já foram triados sorologicamente.

Feitosa \& Krieger (1991), baseados em resultados de estudos sorológicos, especialmente em triagens em doadores de sangue, estudaram a tendência da infecção pelo T. cruzi no Brasil, durante os anos de 1948-1984. Uma prevalência de $11,1 \%$ foi estimada, variando de $0,9 \%$ a $14,1 \%$ de acordo com a região do país, resultados esses que subsidiaram discussões acerca da evolução da infecção nas diferentes regiões.

Hayes \& Schofield (1990) propõem um método para estimar a incidência da doença, baseado na prevalência. Utilizando como exemplo a doença de Chagas e a disponibilidade na literatura de resultados de prevalência obtidos principalmente de doadores de sangue, os autores estimaram o número de casos novos para doença de Chagas para algumas regiões da América Latina mediante a fórmula: 
Incidência $=$ Prevalência $\mathbf{x}$ Taxa de Natalidade $\mathbf{x}$ (fator de correção para idade).

Esta mesma fórmula foi utilizada por Andrade et al. (1992b) que, a partir de resultados de prevalência obtidos em inquérito populacional, estimaram 44 casos novos/ano nos municípios de Posse, Simolândia e Guarani de Goiás, no Estado de Goiás.

A utilização simultânea de indicadores sorológicos e entomológicos tem sido proposta para avaliação do risco de transmissão do T. cruzi. No Brasil, Minter et al. (1973) verificaram para a região de São Felipe, Bahia que o risco de transmissão pelo $\mathbf{T}$. cruzi estava associado à densidade de triatomíneos infectados presentes na moradia, propondo o seguinte indicador para avaliação do fator de risco doméstico (FRD): $\quad$ FRD $=\left(\mathrm{n}^{\circ}\right.$ de barbeiros capturados $\mathrm{x}$ taxa de infecção em barbeiro capturado)/100. Os autores encontraram uma correlação entre o indicador proposto e níveis de infecção detectados em indivíduos na moradia (Minter et al., 1973).

Estudos conduzidos em Castro-Alves, Bahia, no início da década de 70 , mostraram uma associação entre soropositividade em crianças menores de 10 anos, presença de $\mathbf{P}$. megistus e tipo de construção da moradia, em relação a pau-a-pique com adobe quando comparado com tijolo com adobe (Mott et al., 1978). Piesman et al. (1983) descreveram que o número de pessoas na moradia estava relacionado a uma maior densidade de barbeiros. Ainda nessa região, casas com crianças soropositivas apresentaram maior proporção de $\mathbf{P}$. megistus infectados e o risco de soroconversão foi significantemente maior em casas infestadas, particularmente naquelas com altas taxas de densidade de triatomíneo. As taxas de incidência de infecção nessa população rural, durante os nove anos de acompanhamento, variaram de $0,20 / 100$ pessoas-anos a 3,21/100 pessoas-anos, respectivamente para densidade de triatomíneo igual a 0 e maior que 15 (Piesman et al., 1985a; Piesman et al., 1985b).

Garcia-Zapata \& Marsden (1992) descreveram os resultados da intensa 
vigilância entomológica no município de Mambaí, na última década, com taxas de infestação domiciliar de $\mathbf{T}$. infestans decrescendo de 3,5\% a zero,no período de 1985 a 1988 . Esses resultados foram acompanhados pela queda de $28 \%$ para $1 \%$ da soroprevalência de infecção pelo T. cruzi em crianças de 1 a 4 anos, durante o período de estudo (Dias, 1991). Em contrapartida, o T. sordida apresentou tendência a invasão progressiva dos domicílios e a manutenção de altas taxas de infestação do ambiente peridoméstico, porém com baixo índice de infecção de $\mathbf{T}$. cruzi (Garcia-Zapata \& Marsden, 1992).

Na Argentina, Paulone et al. (1991) verificaram que a melhoria da habitação rural, por si só, não foi suficiente para diminuir as taxas de infestação domiciliar, uma vez que o ambiente peridoméstico também necessitaria medidas anti-triatomínicas em sua estrutura. Da mesma forma, a melhoria da moradia não esteve relacionada à taxa de soroprevalência em crianças menores de 5 anos, o que mostra não ter produzido impacto no nível de transmissão do T. cruzi.

Indicadores epidemiológicos de infecção humana, de vetores em potencial de reservatórios animais têm sido analisados em conjunto para avaliar a dinâmica de transmissão do T. cruzi. Em estudo realizado em 20 moradias rurais na Argentina, foi verificado que a presença de cão infectado aumentava o risco da transmissão do T. cruzi em crianças jovens. Os autores concluiram que cães podem servir de sentinela na fase de vigilância para detectar a introdução do $\mathbf{T}$. cruzi no ciclo de transmissão doméstico (Gürtler et al., 1987). Mais recentemente, variáveis referentes ao ciclo de transmissão da infecção (densidade e proporção de triatomíneos infectados, taxa de picada de inseto e distribuição de picadas em homens e animais, soropositividade ao T. cruzi por faixa etária no homem e incidência de infecção no homem) foram incorporadas em modelo teórico de probabilidades proposto por Rabinovich et al. (1990). Esse tipo de abordagem, segundo os autores, permite estimar o nível potencial de risco de transmissão em diferentes casas e definir prioridades para atividades de controle. 
2. JUSTIFICATIVA 


\section{JUSTIFICATIVA}

Vários padrões epidemiológicos de transmissão da infecção pelo T.cruzi podem ser identificados, hoje, no Brasil. Isto implica que diferentes estratégias de controle e monitoramento da infecção devem ser recomendadas de acordo com os diferentes estágios de desenvolvimento sócio-econômico das diferentes regiões. Por exemplo, o controle de triatomíneos no Estado de São Paulo foi alcançado pelo extensivo processo de desmatamento e substituição da flora natural por grandes projetos que incluiram a mecanização da agricultura (Dias, 1988; Litvoc et al., 1990). No entanto, este não pode ser considerado como um padrão homogêneo para o Brasil como um todo. No nordeste de Goiás, por exemplo, ainda existem, hoje, municípios endêmicos para doença de Chagas onde as atividades de lavoura culminam com a invasão do ambiente silvestre pelo homem com construção de habitações precárias, propícias para a colonização por vetores.

Dados do Ministério da Saúde-Programa de Controle da Doença de Chagas mostram uma redução de $83,6 \%$ de T.infestans nos municípios considerados endêmicos, com $75,0 \%$ dos triatomíneos capturados no ambiente peridoméstico (Dias, 1993). Em Goiás, inquérito entomológico conduzido entre 1984 e 1988 detectou T. infestans in $68,2 \%$ dos municípios, mas uma redução drástica da infestação de moradias foi detectada, em anos recentes, na maioria dos municípios. OT.infestans vem sendo substituído por espécies peridomiciliares, como T.sordida e R.neglectus. Entretanto, em contraste com o padrão entomológico do país, taxas de infestação significativas de T.infestans têm sido consistentemente encontradas em habitações de alguns municípios do nordeste do Estado de Goiás (Silva et al., 1992).

A vigilância da infecção pelo T. cruzi torna-se difícil pelo fato de que grande proporção dos casos (infectados) ocorrem de forma assintomática. Assim, as informações para vigilância dependem na maioria das vezes de estudos e inquéritos especiais com estimativas obtidas por amostragem, usualmente em 
aglomerados onde já se sabe que a doença é prevalente. Neste aspecto, a vigilância de infecção em crianças/escolares tem sido utilizada como estratégia para avaliar a eficácia do programa de controle da doença de Chagas. Inquéritos sorológicos para anticorpos anti-T. cruzi em populações de baixa idade tem se mostrado como um . indicador eficiente para avaliação de transmissão ativa (Hoff et al., 1985). No entanto, esse procedimento não tem sido incorporado na rotina do programa de controle da doença de Chagas no Brasil. Estudos de tendência de soroprevalência realizados em crianças e escolares têm indicado a interrupção da transmissão do T. cruzi conseqüente à efetividade do programa de controle de vetores em alguns municípios do Brasil, particularmente nos Estados de São Paulo (Souza et al., 1984). Recentemente, no Encontro Latino Americano sobre Sistemas de Vigilância para Avaliar o Impacto dos Programas de Controle da Doença de Chagas, promovido pela Organização Mundial da Saúde/ Organização Panamericana da Saúde e realizado na Argentina, foi recomendado que os países da América Latina incorporassem oficialmente em seus programas a triagem sorológica de escolares para avaliar o impacto das medidas de intervenção (WHO, 1991a).

Poucas tentativas têm sido feitas para avaliar a redução ou interrupção da transmissão do T. cruzi correlacionando indicadores entomológicos de controle e dados epidemiológicos de estudos analíticos-observacionais. Enquanto estudos de coorte em áreas rurais são de custo elevado e operacionalmente difíceis devido às altas taxas de migração e dispersão da população, estudos caso-controle apresentam como vantagem avaliar vários fatores de risco simultaneamente a um custo mais acessivel.

Estudos caso-controle têm identificado fatores de risco para doença de Chagas em adultos (Zicker et al., 1990c; Zicker et al., 1990e). Este estudo utiliza a metodologia caso-controle para avaliar fatores de risco para a infecção pelo $\mathbf{T}$. cruzi em crianças no Brasil. A identificação de fatores associados à infecção na infância em áreas sob vigilância de vetores pode contribuir para avaliar o impacto das medidas de intervenção e fornecer informações úteis para o planejamento de 
atividades de saúde pública.

Para investigar o efeito de exposições relacionadas ao ambiente doméstico e peridoméstico e variáveis familiares com o risco de infecção pelo T. cruzi na infância, conduziu-se um estudo caso-controle populacional. 


\section{OBJETIVOS}

1. Identificar características do meio ambiente, da família, do comportamento humano e dos vetores associadas à infecção pelo Trypanosoma cruzi na infância. 
pág. 50

4. METODOLOGIA 


\section{1. Área de estudo}

\section{a. Características demográficas da região}

A pesquisa foi realizada em áreas rurais da região nordeste do Estado de Goiás, em 3 municípios contíguos, Posse, Simolândia e Guarani de Goiás, localizados a $600 \mathrm{~km}$ de Goiânia. A Figura 4.1-1 mostra a área de estudo, indicando também os municípios de Formosa, Mambaí e Distrito Federal. No município de Formosa localiza-se a Regional da Fundação Nacional de Saúde (FNS), que atende a região de Posse, Simolândia e Guaraní de Goiás, cujos técnicos estiveram presentes em todas as etapas deste trabalho. O município de Mambaí, limítrofe com a área de estudo, vem sendo monitorado em relação à infecção pelo T. cruzi e os resultados dessas investigações serão comparados aos obtidos neste estudo, especialmente no Capitulo Discussão.

Do total dos 22.308 habitantes de Posse, 1.584 eram crianças de 7-12 anos. Para os municípios de Simolândia (6242 habitantes) e Guarani de Goiás (4.766 habitantes), o número de crianças desta faixa etária foi 301 e 549, respectivamente. A população de estudo é constituída de pequenos proprietários de terra, sendo a agricultura a principal atividade econômica, especialmente lavoura de subsistência. A taxa de migração rural/urbana é pequena e os movimentos populacionais que ocorrem são devido a deslocamentos para áreas da vizinhança e estão diretamente relacionados ao próprio ciclo da colheita de grãos. A região é desprovida de abastecimento de água e energia elétrica e o material de construção utilizado nas casas é principalmente adobe e madeira.

Os municípios de Posse, Simolândia e Guarani de Goiás apresentam baixa densidade populacional, respectivamente $8,9,12,2$ e 3,9 habitantes por $\mathrm{km}^{2}$. A distância entre uma e outra escola variou de 2 a $15 \mathrm{~km}$, o que dificultou o trabalho de campo para a seleção dos participantes do estudo, especialmente durante a estação das chuvas, pela precariedade das vias de acesso não pavimentadas. Acresce-se o fato de que o trabalho de campo teve que levar em conta o calendário 
escolar, para facilitar a coleta de material, realizada nas escolas.

b. Características da região quanto à soroprevalência pelo Trypanosoma cruzi e índices entomológicos

A seleção das áreas de estudo privilegiou regiões com altas taxas de prevalência de infecção pelo T. cruzi em anos anteriores e áreas submetidas à atividades de controle de vetores na última década. Desta forma, para escolha das regiões de estudo, levou-se em conta os resultados do inquérito sorológico nacional para infecção chagásica realizado de 1975 a 1980 por municípios do interior do estado (Camargo et al., 1984). Uma soroprevalência global de 7,4\% foi obtida para o Estado de Goiás naquele estudo, com taxas de 23,1\% e 11,7\%, respectivamente, para Posse/Simolândia e Guarani de Goiás, nas faixas etárias de 7-14 anos.

Resultados do inquérito entomológico nacional realizado no ano de 1980 registraram índices de infestação e dispersão de 42,1\% e $91,7 \%$ para Posse/Simolândia e 64,2\% e 96,5\%, respectivamente para Guarani de Goiás, tendo como principais vetores $\mathbf{T}$. infestans e $\mathbf{T}$. sordida. De acordo com informações fornecidas pela Fundação Nacional de Saúde de Goiás, regional de Goiânia, a área foi submetida a borrifação com inseticida (Deltametrim) no ano de 1984, correspondendo à fase de ataque do Programa de Controle da Doença de Chagas. No entanto, devido a dificuldades financeiras para aquisição de inseticidas, o processo de borrifação das casas tem sido descontínuo, o que tem contribuído para a manutenção de índices entomológicos significativos naqueles municípios. Recente levantamento entomológico, realizado no município de Posse em 1991, com auxílio da equipe de campo desse projeto, ainda detectou índices de infestação e dispersão de $12,6 \%$ e $60,5 \%$, respectivamente, mostrando a necessidade de medidas de implementação de combate ao vetor (Figura 4.1-2). 


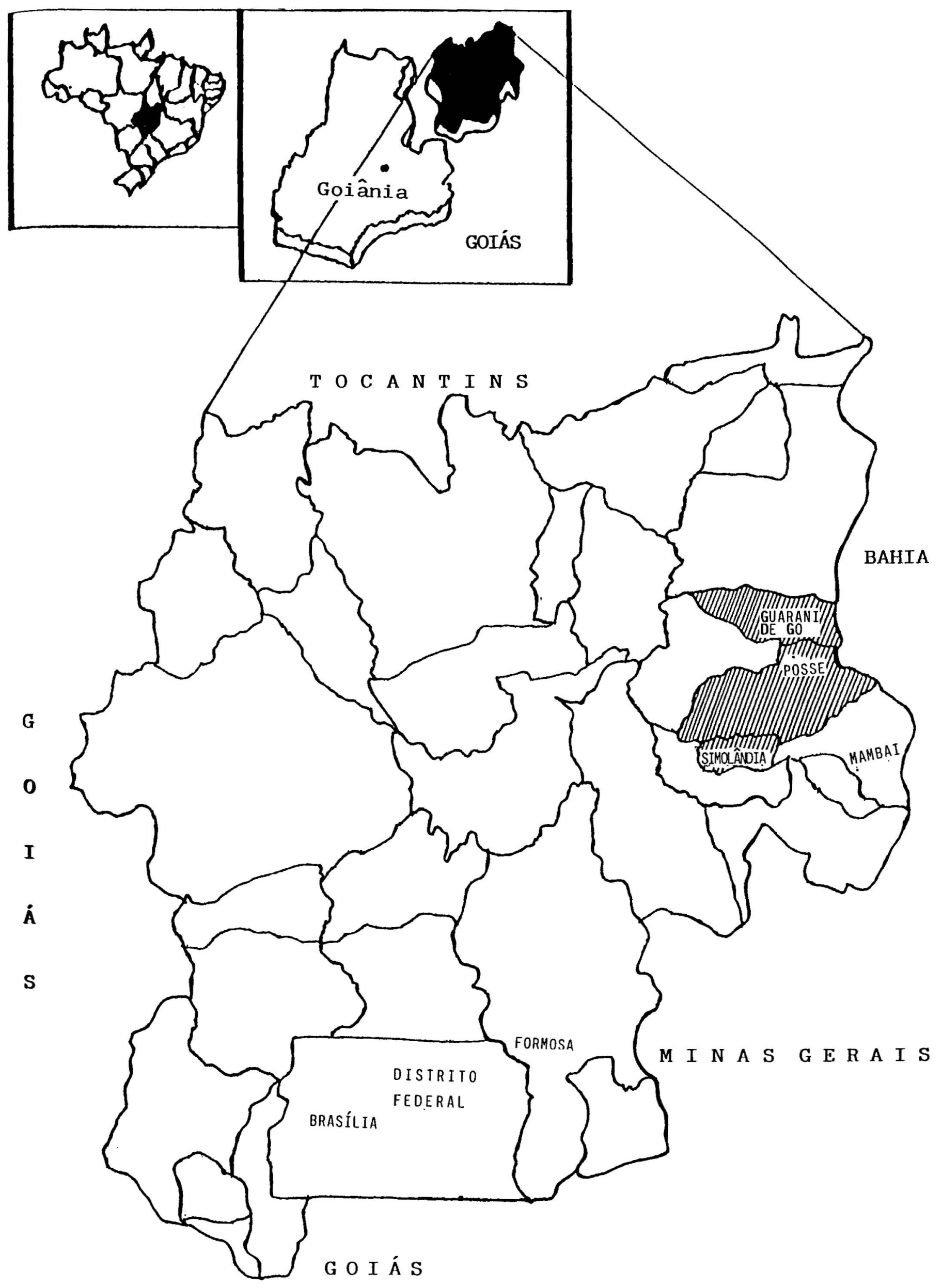

Área de estudo: municípios de Posse, Simolândia e Guarani de Goiás.

Figura 4.1.1- Região Nordeste de Goiás dividida em microrregiões. de acordo com a FIBGE. 
Figura 4.1-2 Indicadores entomológicos do município de Posse, Goiás

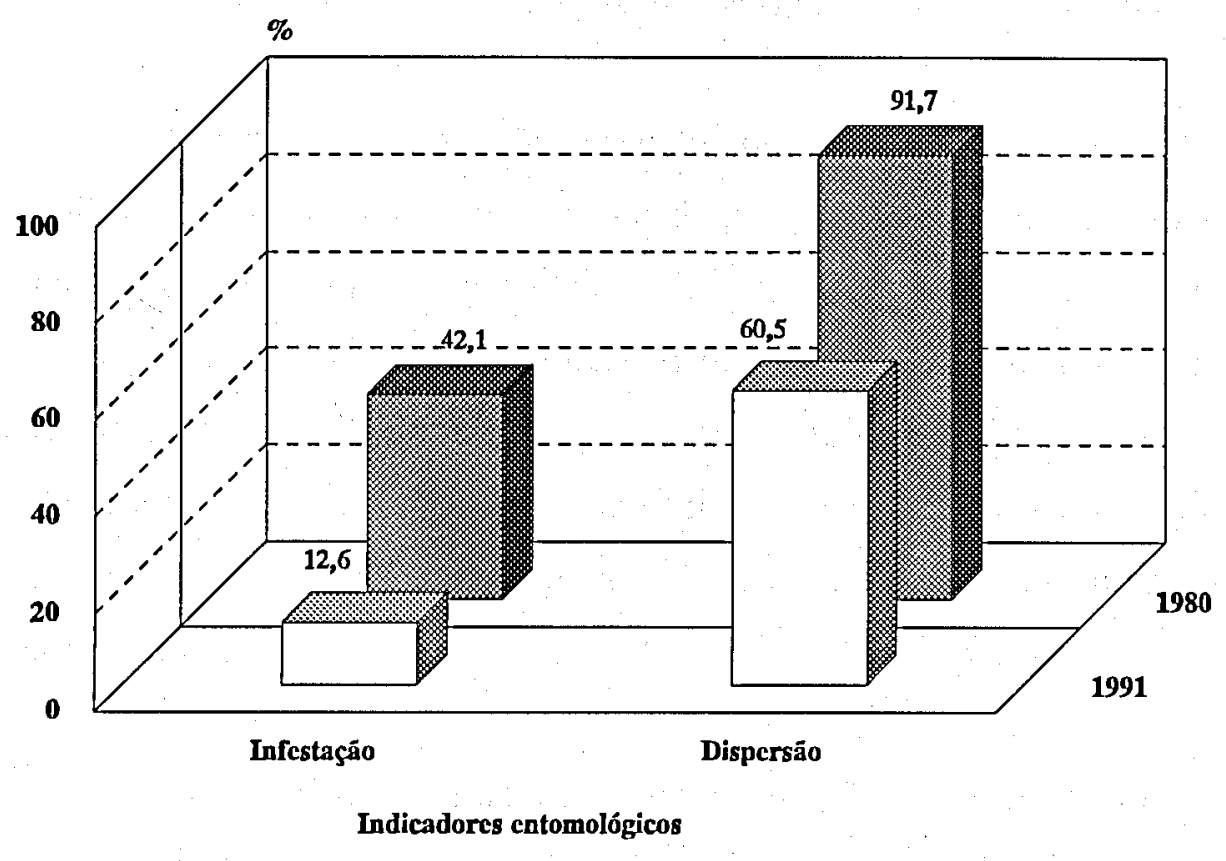




\subsection{População de estudo}

O presente estudo incluiu crianças de 7 a 12 anos selecionadas em escolas rurais. A estratégia de incluir somente escolares levou em conta as dificuldades operacionais de uma investigação casa a casa em regiões de baixa densidade demográfica.

\subsection{Delineamento do estudo: fluxograma de atividades}

A investigação foi delineada como um estudo caso-controle (Breslow \& Day, 1980) e é parte de um projeto maior de pesquisa, o qual inclui também um ensaio terapêutico de campo, controlado, aleatório duplo cego com benzonidazol para tratamento de crianças com infecção pelo Trypanosoma cruzi, que está sendo realizado concomitantemente. Ambas as pesquisas estão relacionadas a um estudo de prevalência, que constituiu a fase inicial dos trabalhos, para identificar crianças soropositivas e soronegativas para fazer parte do estudo caso-controle e do ensaio terapêutico.

Um mapa da área de estudo com a indicação de todas as escolas rurais foi construído para este trabalho, com auxílio da Fundação Nacional da Saúde. O Programa de Merenda Escolar e a Secretaria de Educação do Estado de Goiás forneceram as informações demográficas referentes aos alunos da região. A Figura 4.3-1 mostra as 46 localidades incluídas no estudo, que corresponderam a 60 escolas rurais, com 20 a 40 alunos cada. Estima-se que $90 \%$ das crianças da região estavam matriculadas e freqüentando as referidas escolas.

Dos 2.434 escolares estimados para os 3 municípios, $1.990(82,0 \%)$ foram incluídos na investigação sorológica, sendo $90,0 \%$ de Posse, $85,7 \%$ de Simolândia e $55,9 \%$ de Guarani de Goiás. 


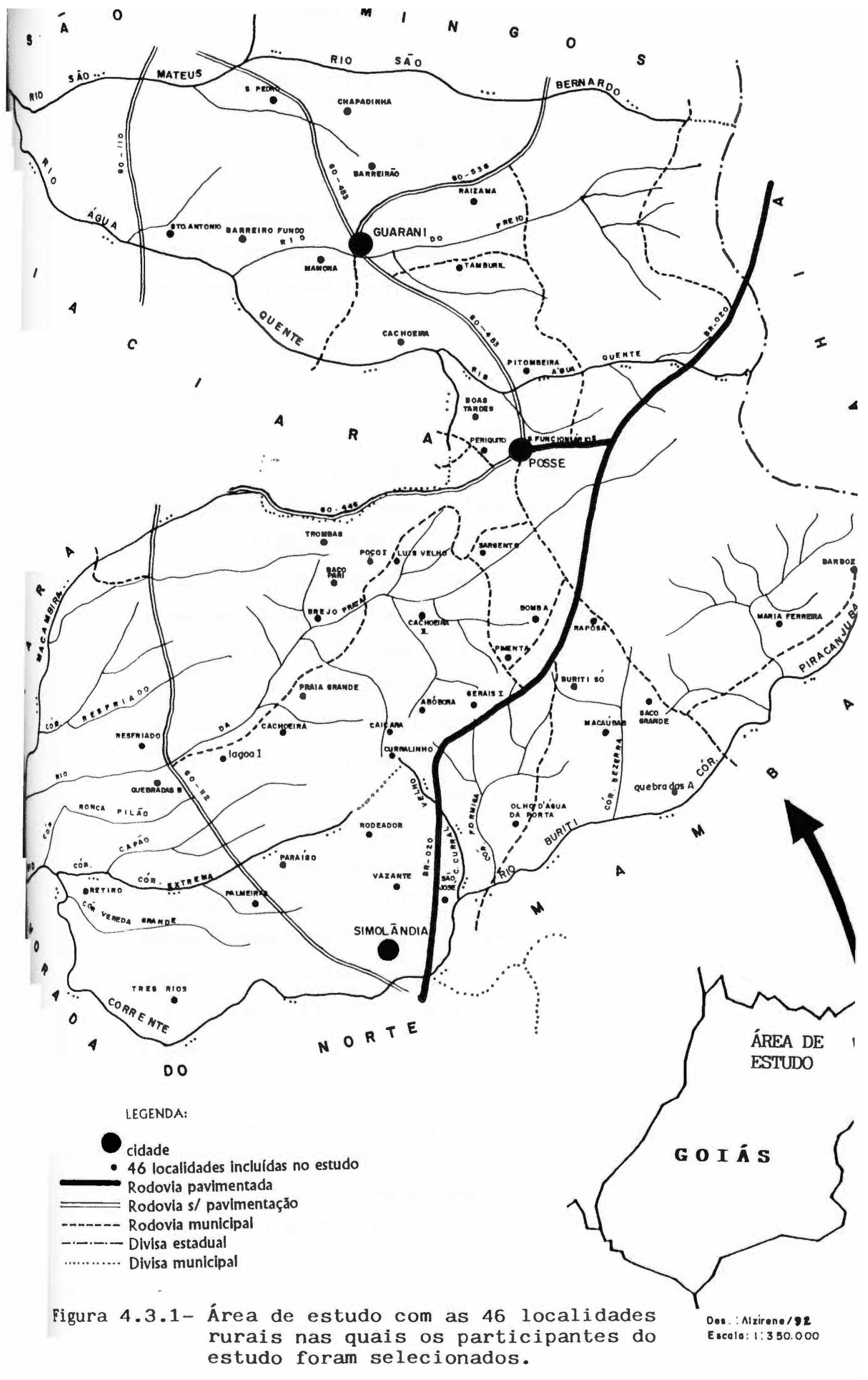




\section{a. Fluxograma do trabalho de campo}

O fluxograma desenvolvido no trabalho de campo é apresentado na Figura 4.3-2. Inicialmente, as comunidades foram contatadas através das autoridades locais e de líderes, os quais foram convidados a colaborar com o estudo.

As escolas foram visitadas para explicar aos professores os objetivos do estudo e planejar a investigação sorológica. Uma lista das crianças por escola era preparada semanalmente e uma equipe, constituída por um médico, um residente de Medicina Preventiva e Social e um auxiliar, viajava a cada 15 dias para a área de estudo, onde um técnico da Fundação Nacional de Saúde (FNS) juntava-se à equipe para auxiliar na identificação das localidades. As professoras eram comunicadas com antecedência, por funcionários da FNS, quanto à data da visita e solicitavam aos pais que comparecessem naquela data a fim de receberem informações sobre a pesquisa. Cerca de 7 escolas eram visitadas pela equipe a cada viagem e aproximadamente 250 amostras de sangue eram colhidas por semana. Uma ficha contendo nome do participante, da escola, dos pais, do município, sexo, idade e endereço, era preenchida para cada criança, e uma amostra de sangue era colhida da polpa digital em papel de filtro, para realização de testes sorológicos.

Os testes sorológicos (imunofluorescência, hemaglutinação e ELISA) foram realizados no Laboratório de Pesquisa de Doença de Chagas, em Goiânia, no Instituto de Patologia Tropical e Saúde Pública da Universidade Federal de Goiás (Luquetti, 1990). Os 3 testes eram realizados independentemente em cada amostra e os resultados eram comparados somente após todas as análises terem sido completadas.

Crianças com pelo menos 2 testes sorológicos positivos no eluato foram submetidas a coleta de sangue venoso nas escolas para confirmação dos resultados obtidos no eluato, utilizando-se as mesmas 3 técnicas. No intuito de se evitar que indivíduos com resultados sorológicos limítrofes fossem incluídos como casos, 
utilizou-se maiores pontos de corte, nesta etapa, respectivamente $\mathrm{HAI} \geq 1: 16 \mathrm{e}$ $\mathrm{IFI} \geq 1: 40$.

Para viabilizar a coleta de sangue nas escolas, cartas convite eram enviadas para os responsáveis de cada participante, incluindo informações sobre os resultados dos testes anteriormente realizados na criança e solicitando o comparecimento na data agendada para prosseguimento das investigações. Foram considerados como casos crianças com pelo menos 2 testes positivos no sangue venoso e um número duas vezes maior de crianças soronegativas selecionadas aleatoriamente por freqüência de estratos de idade, sexo e escola foram também submetidas à coleta de sangue venoso nas escolas. Foram consideradas como controles crianças com 3 testes sorológicos negativos no sangue venoso. Para as situações em que não houve simultaneidade de resultados soronegativos, um novo controle em potencial foi selecionado. Por motivos operacionais as áreas de estudo foram divididas em 3 setores e foram cobertas simultaneamente por 3 equipes de campo, constituídas por 4 técnicos cada uma ( 9 da FNS e 3 entrevistadores treinados). As casas dos casos e dos controles foram visitadas pelas equipes de campo para aplicar um questionário para avaliação de possíveis fatores de risco relacionados à soropositividade ao T. cruzi em crianças e proceder à captura de triatomíneos no domicílio e peridomicílio. A estratégia de formação de 3 equipes para o trabalho de campo foi adotada para efetuar um rápido controle de vetores do ambiente doméstico e peridoméstico, fornecendo um mapeamento inicial de uma amostragem das casas da região, indicando, assim, localidades prioritárias para as medidas de intervenção a serem adotadas pela FNS. 
Figura 4.3-2 Fluxograma do trabalho de campo

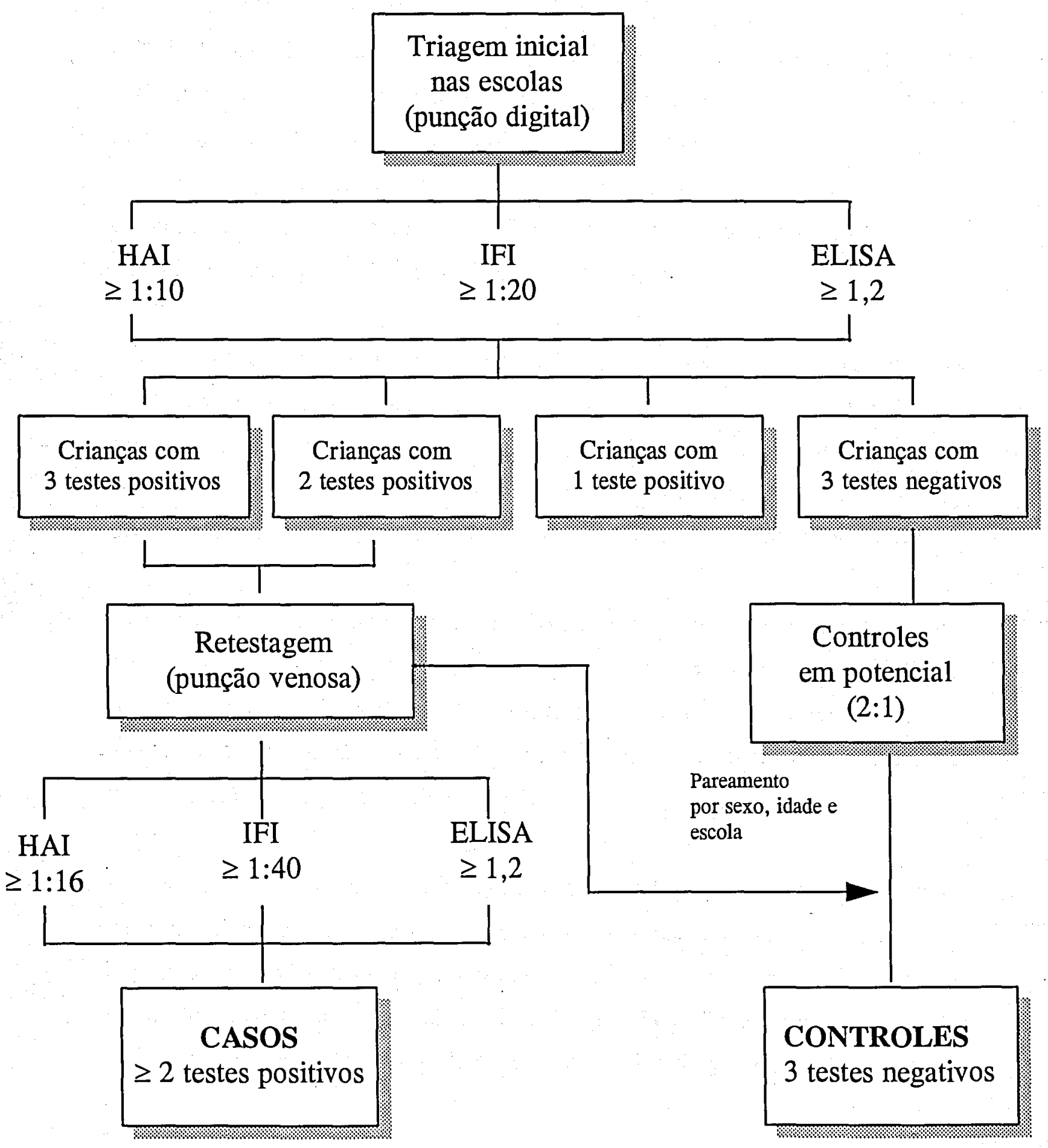




\subsection{Amostragem e amostra}

O tamanho da amostra foi calculado considerando-se a exeqüibilidade do projeto em termos logísticos e de tempo e o número de crianças soropositivas para infecção pelo T. cruzi necessário para realização do estudo caso-controle.

Considerando-se que diferentes variáveis de exposição seriam estudadas, o cálculo do tamanho da amostra levou em conta a diferença a ser detectada ou o odds ratio entre casos e controles para cada exposição, ou nível de exposição, ou, pelo menos, para a mais importante exposição. Considerando-se as dificuldades de se estimar a proporção de indivíduos para diferentes exposições entre os controles, optou-se por explorar diferentes possibilidades na detecção de várias diferenças, assumindo um amplo espectro de freqüência de exposições.

Para o cálculo do tamanho da amostra optou-se pelo uso da fórmula habitualmente utilizada em estudos caso-controle não pareado (Schlesslman, 1982), com dois controles por caso (2:1), devido à similaridade dos resultados obtidos quando se usam fórmulas para estudos pareados e não pareados. Desta forma, Cousens et al. (1988) consideram desnecessário a utilização de fórmulas especiais.

A Figura 4.4-1 apresenta o tamanho da amostra necessário para detectar um dado odds ratio assumindo-se diferentes proporções de exposição entre os controles. Assim, para uma proporção de 2 controles por caso, calculou-se que 150 casos seriam suficientes para detectar odds ratios de 2,0 a 2,2 para uma variação de freqüências de exposição de $15 \%$ a $60 \%$.

Triagem sorológica - As únicas informações disponíveis de soroprevalência local incluindo a faixa etária de escolares (7-14 anos) eram provenientes do inquérito sorológico nacional, realizado no período de 1975 a 1980 . Naquele estudo, foram obtidas taxas de 23,1\% e 11,7\% para Posse/Simolândia e Guarani de Goiás, respectivamente. Considerando-se que a borrifação com inseticidas foi 
implementada a partir de 1984 nessas regiões, a utilização desses valores como referência para o cálculo do tamanho da amostra necessário para esse estudo seria inadequada.

O número de crianças investigadas sorologicamente na triagem inicial foi de 1990, com a detecção de 158 crianças soropositivas a pelo menos 2 testes, por punção digital, representando uma soroprevalência de 7,9\%. O tamanho da amostra final para o estudo de caso-controle foi de 149 casos (crianças soropositivas) e 298 controles (crianças soronegativas).

4.5 Definição e seleção de casos e de controles

\section{CASOS}

Foram consideradas como casos todas as crianças com pelo menos dois testes sorológicos positivos para anticorpos anti-T. cruzi em amostra de sangue venoso.

\section{CONTROLES}

Foram selecionados 2 controles soronegativos para cada caso, com todos os 3 testes sorológicos (IFI, ELISA e HAI) negativos para anticorpos anti-T. cruzi em sangue venoso. Os controles foram selecionados pareados por sexo e por freqüência de idade em dois estratos: 7-9 e 10-12 anos. Apesar da pequena variabilidade sócio-geográfica entre as 3 comunidades, o pareamento dos controles foi realizado também por escolas com o objetivo de uma aproximação das condições sócioeconômicas entre casos e controles e finalidade de análise. Quando mais de duas crianças eram elegíveis como controles procedeu-se a sorteio. 
Figura 4.4-1 Tamanho da amostra para estudo de caso-controle $(1: 2)$ vs exposiçáo em controles $(\alpha=0,05)$.

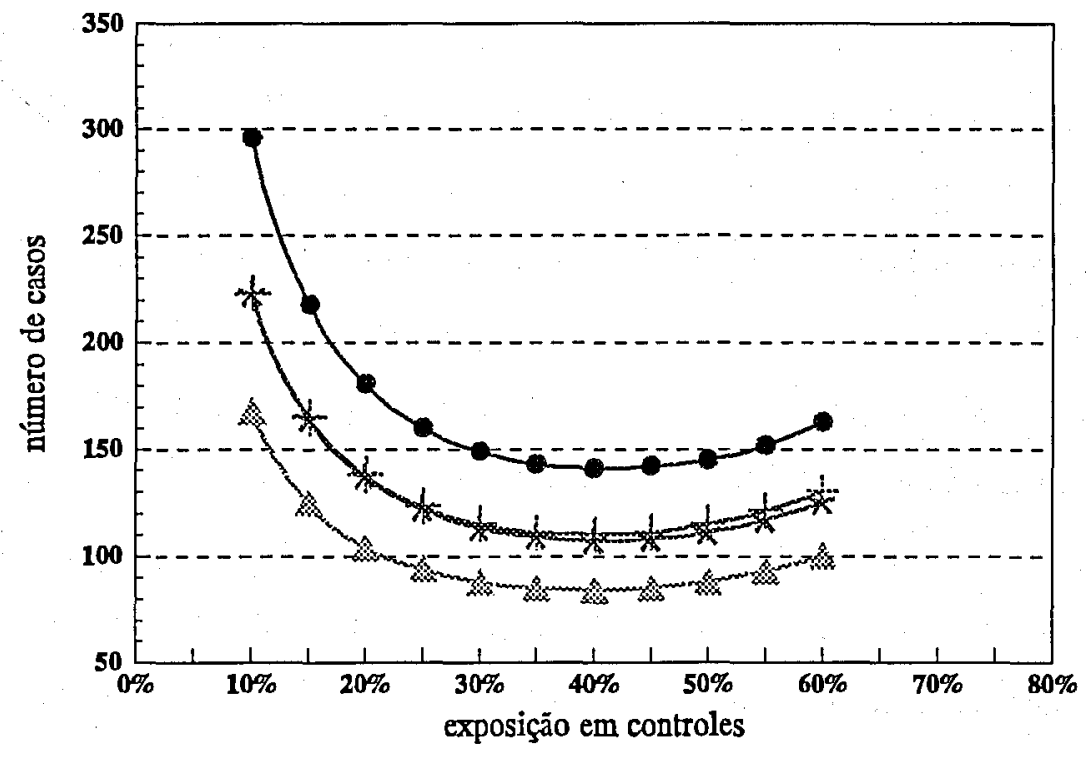

- Odds ratio $=2,0($ Poder $=90 \%)$ + Odds ratio $=2,2$ (Poder $=90 \%)$

\& Odds ratio $=2,0$ (Poder $=80 \%) \approx$ Odds ratio $=2,2$ (Poder $=80 \%$ ) 


\section{BANCOS DE DADOS}

Inicialmente 158 crianças apresentaram pelo menos 2 testes positivos a anticorpos anti-T.cruzi eluídos do papel de filtro. Estes resultados foram confirmados em $153(96,8 \%)$ crianças, após retestagem em sangue venoso utilizando-se as mesmas técnicas. A Figura 4.5-1 mostra o fluxograma para seleção de casos e controles incluindo dois bancos de dados. No primeiro deles (banco de dados 1), 149 casos e 298 controles foram incluídos. Para o banco de dados 2 , a seleção de casos e controles excluiu conglomerado de soropositividade ao T. cruzi nas moradias e somente uma criança soropositiva por domicílio foi selecionada como caso. Casos e controles que moravam na mesma casa também foram excluídos. Dois controles pareados por sexo e freqüência de idade foram selecionados obtendo-se 89 casas somente com criança caso e 178 casas somente com criança controle no banco de dados 2. Quando mais de uma criança, caso ou controle, morava na mesma residência, a escolha da criança foi feita levando em conta a primeira delas triada sorologicamente. Assim, foram classificadas como moradia de caso as casas só de crianças soropositivas e como moradia de controle as moradias só com crianças soronegativas. A Tabela 4.5-1 apresenta a distribuição de casos e controles em cada uma das casas incluídas em ambos os bancos de dados. Do total de 336 domicílios do banco de dados 1, excluiram-se 25 nos quais residiam casos irmãos de controles, correspondendo à exclusão de 30 casos e 28 controles. Dos 311 domicílios restantes, foram excluídos 30 casos das moradias nas quais residiam mais de um caso e 48 controles das casas com mais de um controle. Isto significou a exclusão de 60 casos do total inicial de 149, de tal forma que o banco de dados 2 incluiu 89 casos. Os 222 controles em potencial [298- $(48+28)]$ foram pareados por sexo e idade na proporção de 2 controles para cada caso (2:1), excluindo-se 44 moradias que corresponderam a 44 controles. Dessa forma, o banco de dados 2 ficou constituído por 178 (222-44) controles e 89 casos, obtendo-se 267 casas. Somente um participante por família foi incluído na análise, o que permitiu controlar para exposições comuns entre membros da mesma família, pois apenas um questionário foi considerado para cada moradia. Neste banco de 
dados 2 foram testadas variáveis relativas aos vetores, peridomicílio e domicílio. Odds ratios em análise univariada e multivariada com limites de confiança $95 \%$ foram calculados através de modelo log-linear (Souza \& Benício, 1985), utilizandose regressão logística condicional.

Ainda em relação ao banco de dados 2 , calculou-se também a sensibilidade (S) (Fletcher et al., 1983) das seguintes variáveis de exposição para detecção de moradia de caso: sorologia dos pais, relato de triatomíneo na unidade domiciliar, captura de triatomíneo ou vestígios na moradia. Para tanto, moradia de caso foi considerada como positivo verdadeiro. A especificidade das variáveis na detecção de moradia de controle não pode ser calculada uma vez que a visita domiciliar foi realizada somente nas casas de crianças selecionadas como controles e não em todas as casas de crianças soronegativas, fato este que induziria a vício de seleção. 


\section{Figura 4.5-1 Fluxograma para seleção de casos e controles}

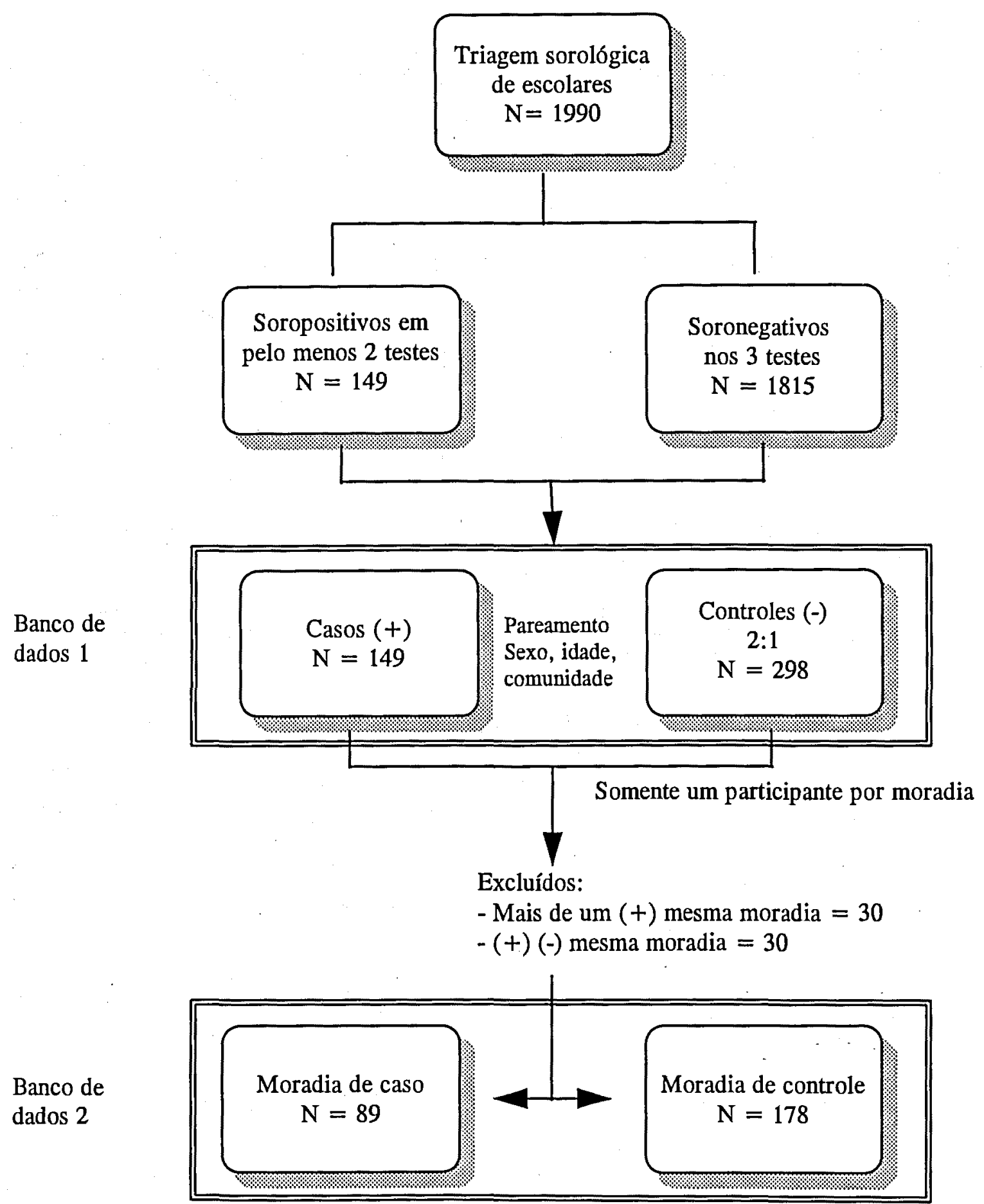


Tabela 4.5-1

Distribuição do número de casos e controles por moradia de acordo com o banco de dados.

\begin{tabular}{|c|c|c|c|c|}
\hline \multirow[t]{2}{*}{$\begin{array}{c}\mathrm{N}^{\circ} \\
\text { casos }\end{array}$} & \multirow[t]{2}{*}{$\begin{array}{c}\mathrm{N}^{\mathrm{o}} \\
\text { controles }\end{array}$} & \begin{tabular}{lr}
\multicolumn{3}{l}{ Banco de dados 1} \\
casos & controles \\
$n=149$ & $n=298$
\end{tabular} & $\begin{array}{l}\text { Banco de dados excluindo } \\
\text { casos irmãos de controles } \\
119 \text { casos } 270 \text { controles }\end{array}$ & $\begin{array}{cr}\text { Banco de dados } 2^{2} \\
\text { casos } & \text { controles } \\
n=89 & n=178\end{array}$ \\
\hline & & $\mathrm{N}^{0}$ casas $(\%)$ & $N^{o}$ casas (\%) & $\mathrm{N}^{0}$ casas (\%) \\
\hline 0 & 1 & $183(54,5)$ & $183(58,8)$ & $139(52,1)$ \\
\hline 0 & 2 & $31(9,2)$ & $31(10,0)$ & $\underline{31}(11,6)$ \\
\hline 0 & 3 & $7(2,1)$ & $7(2,3)$ & I $(2,6)$ \\
\hline 0 & 4 & $1(0,3)$ & $1(0,3)$ & $\underline{1}(0,4)$ \\
\hline 1 & 0 & $64(19,0)$ & $64(20,6)$ & $64(24,0)$ \\
\hline 1 & 1 & $19(5,7)$ & - & - \\
\hline 1 & 2 & $1(0,3)$ & - & - \\
\hline 2 & 0 & $22(6,5)$ & $22(7,1)$ & $22(8,2)$ \\
\hline 2 & 1 & $3(0,9)$ & - & - \\
\hline 2 & 2 & $2(0,6)$ & - & - \\
\hline 3 & 0 & $2(0,6)$ & $2(0,6)$ & $2(0,7)$ \\
\hline 5 & 0 & $1(0,3)$ & $l(0,3)$ & $1(0,4)$ \\
\hline Total & & $336(100,0)$ & $311(100,0)$ & $267(100,0)$ \\
\hline
\end{tabular}

4 Somente um participante por moradia foi incluido no estudo. Excluidos casos e controles residindo na mesma casa

Banco de dados 2: números sublinhados correspondem a controles e números em negrito correspondem aos casos 


\subsection{Exames sorológicos}

A investigação sorológica foi planejada levando-se em conta: a) as dificuldades operacionais no acesso à população alvo por tratar-se de área rural, com baixa densidade populacional; b) o grande número de crianças a serem investigadas na triagem sorológica inicial; c) as dificuldades relativas aos procedimentos de coleta de sangue e armazenamento de amostras em condições de campo. Desta forma, a estratégia adotada para a investigação sorológica foi a realização de triagem em paralelo ( 3 técnicas) na fase inicial da investigação sorológica e triagem em série na segunda fase, através da retestagem das amostras positivas. Na triagem em paralelo foram utilizados pontos de corte abaixo dos estabelecidos para critério diagnóstico final de caso, com o objetivo de aumentar a sensibilidade da deteç̧ão de crianças possivelmente infectadas (Galen \& Gambino, 1975), otimizando o custo benefício da investigação. Por outro lado, na fase de retestagem, os pontos de corte foram aumentados, obtendo-se desta forma alta especificidade na definição de não casos, condição indispensável em estudos casocontrole (Hennekens \& Buring, 1987; Pless et al., 1992). A Figura 4.3-2 mostra os pontos de cortes utilizados na triagem inicial (punção digital) e na triagem para confirmação sorológica (punção venosa).

a. Coleta de sangue e testes sorológicos: Triagem. A coleta de sangue foi realizada nas escolas rurais. Para a triagem sorológica inicial, o sangue foi obtido de polpa digital e depositado em papel de filtro (Whatman ${ }^{\circledR} 1$ ), preenchendo-se com uma única camada de sangue dois círculos de $1,6 \mathrm{~cm}$ de diâmetro para cada criança, de acordo com a técnica modificada de Guimarães et al. (1978) (Figura 4.6-1). Ao mesmo tempo, uma ficha de identificação era preenchida, incluindo nome, endereço, escola, município, sexo e idade (Anexo 1). As amostras de sangue e a ficha de identificação, consecutivamente numeradas, eram etiquetadas em duplicata. Após a secagem por 60 minutos à temperatura ambiente, os papéis de filtro eram embalados com papel celofane e papel alumínio, guardados em congelador à temperatura de $-20^{\circ} \mathrm{C}$, na Fundação Nacional de Saúde (FNS), regional 
de Formosa, e enviados semanalmente para Goiânia em caixa térmica portátil contendo gelo. Em Goiânia, os papéis de filtro permaneciam estocados em freezer à $-20^{\circ} \mathrm{C}$, no Laboratório de Doença de Chagas, até o processamento das reações.

As reações sorológicas foram realizadas no Laboratório de Doença de Chagas da Universidade Federal de Goiás sob a responsabilidade do Prof. Alejandro Luquetti do Departamento de Parasitologia. Cada círculo da gota de sangue original era cortado ao meio utilizando-se uma tesoura, após o que era transferido para o fundo de um recipiente de vidro (frasco de $5 \mathrm{ml}$ ). Para obtenção dos eluatos, eram adicionados $63 \mu 1$ de solução salina, tamponada com fosfatos $0,01 \mathrm{M}$ (SST), $\mathrm{pH}$ 7,2. Os eluatos permaneciam à temperatura de $4{ }^{\circ} \mathrm{C}$ por 12 a 16 horas e a seguir os papéis de filtro eram pinçados para a parede dos vidros para permitir o escoamento do eluato. Após aproximadamente 1 hora, eram retirados os volumes necessários (10 $\mu$ l para ELISA, $10 \mu 1$ para IFI e $10 \mu 1$ para HAI) e testados para detectar anticorpos anti-T. cruzi da classe IgG por reações de HAI, IFI e ELISA. A metade restante do papel de filtro era novamente conservada no congelador, no máximo por 60 dias, para eventual repetição das técnicas.

Considerando cada eluato equivalente a uma diluição de 1:5 da gota de sangue inicial colhida no papel de filtro, os mesmos foram testados na diluição de 1:10 na HAI, 1:10 e 1:20 na IFI, e 1:100 na técnica imunoenzimática de ELISA.

Hemaglutinação indireta - A reação de HAI foi realizada de acordo com a padronização de Camargo et al., 1973, sendo utilizados kits comerciais fornecidos pela Imunoserum ${ }^{\circledR}$ (São Paulo), e microplacas descartáveis de 96 poços de fundo em $\mathrm{U}$, nos quais se adicionou $10 \mu \mathrm{l}$ de diluente do kit mais $0,5 \%$ de albumina bovina e $20 \mu \mathrm{l}$ de hemáceas sensibilizadas. A leitura era efetuada após 2 horas. 0 eluato era considerado positivo quando a imagem no fundo do poço ocupava área maior que $50 \%$, duvidoso quando a imagem ocupava entre $25 \%$ e $50 \%$ da área e negativo quando a imagem era puntiforme. Se positivo, era classificado como reagente. No caso de resultado limítrofe, a amostra era retestada posteriormente 
para melhor definição. Para este procedimento utilizou-se a segunda metade do papel de filtro.

Imunofluorescência - A reação de IFI foi processada de acordo com a técnica descrita por Camargo, 1966. Como reagente foram utilizados anticorpos anti-IgG humana conjugados a isotiocianato de fluoresceína, os quais foram obtidos comercialmente (Biolab ${ }^{\circledR}$, São Paulo, Fluoline G, lote 10609). A diluição do conjugado considerada ótima para esse lote foi de 1:100. O antígeno foi preparado a partir de epimastigotas de cultivo de T. cruzi cepa $\mathrm{Y}$, mantidas in vitro, em meio líquido de cultura LIT (Liver Infusion Tryptose), no Laboratório de Doença de Chagas do Hospital das Clínicas/UFG. O eluato foi considerado reagente se positivo na diluição de 1:20. A leitura foi realizada em microscópio Olympus CBA de epi-iluminação.

ELISA - A reação de ELISA foi feita de acordo com a técnica de Voller (Voller et al., 1975). Foram utilizadas placas de polivinil em U (Hemobag ${ }^{\circledR}$, Produtos Cirúrgicos LTDA, São Paulo) sensibilizadas com antígeno de T. cruzi preparado a partir de cultivos, sendo o mesmo processado por 6 ciclos sucessivos de congelamento e descongelamento às temperaturas de $-196^{\circ} \mathrm{C}$ (nitrogênio líquido) e $+37^{\circ} \mathrm{C}$ (banho-maria). O conjugado anti-IgG humana marcado com peroxidase foi obtido da Biolab ${ }^{\circledR}$ (São Paulo). A leitura foi realizada em espectrofotômetro de microplacas CLS (Cambridge Life Sciences) em comprimento de onda de $492 \mathrm{~nm}$. O ponto de corte foi estabelecido para cada placa, elaborando-se uma curva com um soro controle positivo de baixa reatividade, outro soro de reatividade limiar (controle positivo muito baixo), um soro controle negativo de absorbância superior aos negativos (controle negativo alto) e um soro controle negativo além da linha de base com a absorbância de poços sem soro. Todos estes soros foram distribuídos na placa em duplicata. A medida da leitura em absorbância de cada um destes controles foi calculada e estabelecido o ponto de corte da placa, aplicando a seguinte fórmula: 


\section{Controle Positivo Baixo + Controle Positivo Muito Baixo \\ Absorbância $=$ \\ Controle Negativo Alto + Controle Negativo Baixo}

A média de leitura (absorbância) de cada eluato em duplicata foi dividida pelo ponto de corte, calculado para a placa. O quociente, se igual ou superior a 1,2, era considerado eluato positivo. Para os valores entre 0,9 e 1,1 , considerados limítrofes, os testes sorológicos foram repetidos posteriormente com a metade restante do papel de filtro.

Critério de Positividade - triagem. Cada teste sorológico foi realizado por técnicos que não conheciam os resultados dos demais testes. Os resultados dos eluatos foram classificados como negativos quando as 3 técnicas eram negativas.

Crianças com pelo menos dois dos testes sorológicos positivos realizados na amostra de sangue colhido por punção digital foram inicialmente selecionadas como eluato positivo. Nesta etapa, resultados positivos foram definidos como se segue: IFI $\geq 1: 20$, ELISA $\geq 1,2$ e HAI $\geq 1: 10$.

b. Coleta de sangue venoso e testes sorológicos - retestagem. A segunda fase do inquérito sorológico consistiu de coleta de amostra de sangue venoso, com Vacutainer ${ }^{\circledR}$, de todas as crianças potencialmente elegíveis para o estudo casocontrole (eluato positivo) a fim de se confirmar os resultados do eluato, utilizandose as 3 técnicas já referidas. Uma amostra de $10 \mathrm{ml}$ de sangue venoso era coletada de cada criança, nas escolas, sob a supervisão do coordenador de campo. O sangue era transportado em veículos da FNS, imediatamente após a coleta, para o Laboratório da cidade de Posse, onde era realizada a centrifugação e separação dos soros, os quais permaneciam no freezer do laboratório da cidade. Ao final de cada semana os soros eram enviados para Goiânia, em caixas térmicas contendo gelo, permanecendo estocados a $-20^{\circ} \mathrm{C}$ no Laboratório de Doença de Chagas/UFG, até o processamento das reações (Figura 4.6-2). 
Nesta fase do inquérito sorológico as amostras de sangue venoso eram enviadas ao Laboratório de Doença de Chagas com numeração diferente daquelas utilizadas para o eluato, para evitar tendenciosidades no resultado dos testes sorológicos.

As reações de HAI, IFI e ELISA foram processadas de acordo com as técnicas já referidas. O critério de positividade utilizando-se o sangue venoso foi o mesmo que o do eluato para ELISA. Para HAI foi considerado positivo um título $\geq 1: 16$ e, para IFI, $\geq 1: 40$. 


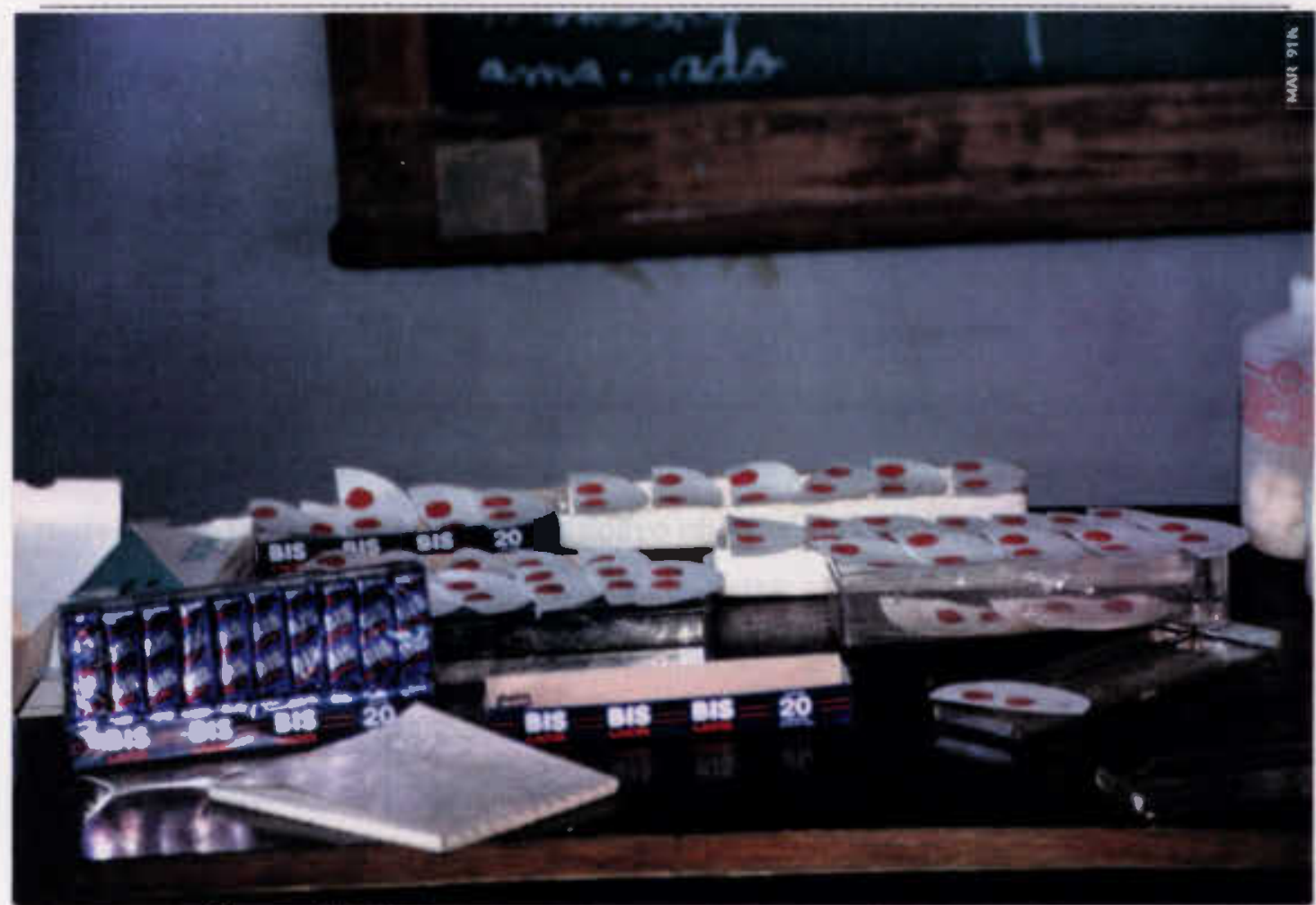

Figura 4.6-1.

Papéis de filtro em processo de secagem

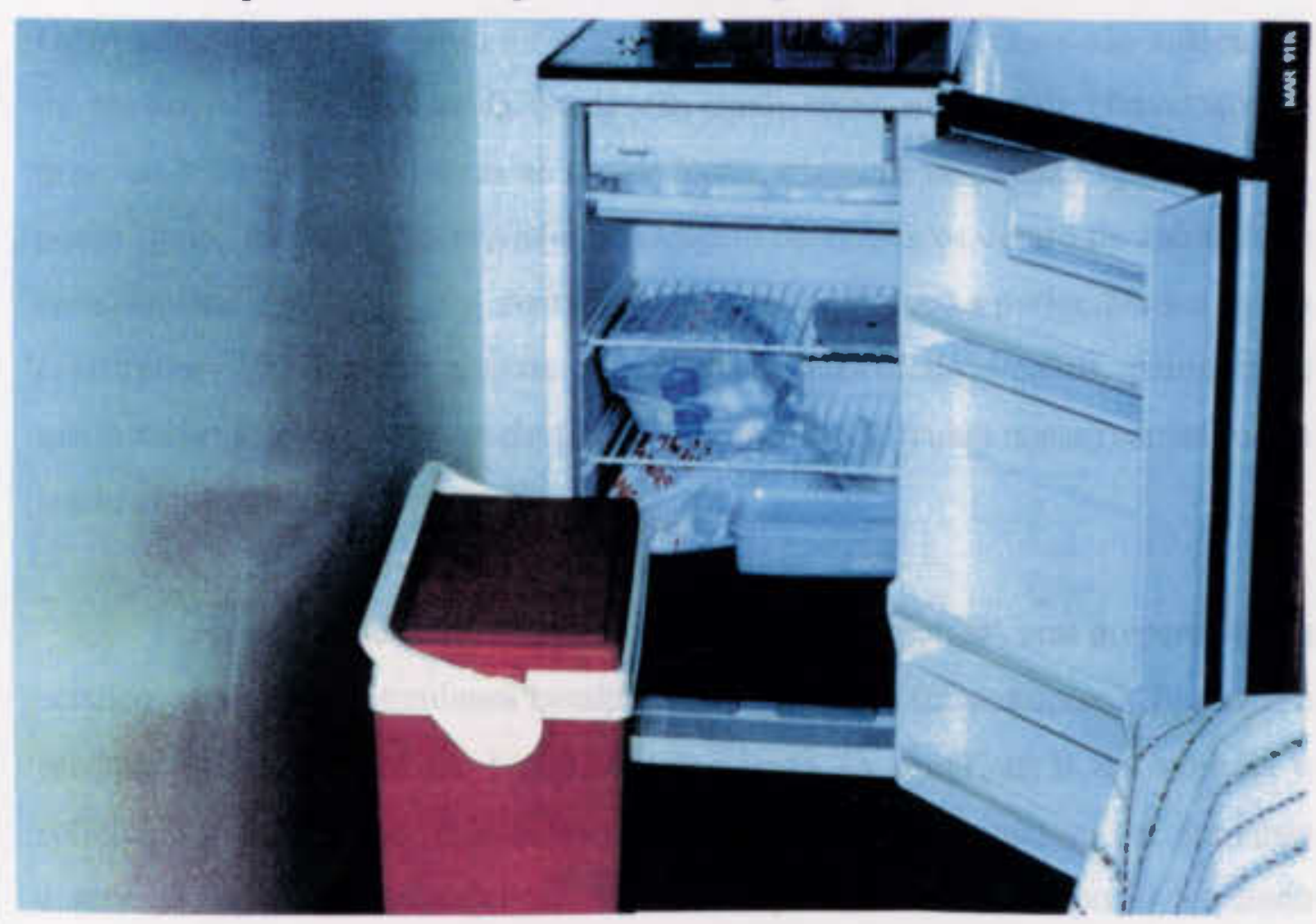

Figura 4.6-2.

Papéis de filtro embalados para transporte. 


\subsection{Avaliação de possíveis fatores de risco}

Um questionário pré-codificado foi elaborado para se obter informações sobre variáveis de exposição. Um estudo piloto foi conduzido para testar a exeqüibilidade do questionário e reformulá-lo de acordo com as dificuldades detectadas no preenchimento. Foram treinadas três equipes de campo, com um coordenador em cada uma delas e supervisão de um entomologista, para visitar as moradias dos casos e dos controles, com o objetivo de entrevistar o responsável pela família e realizar um levantamento entomológico na unidade domiciliar (domicílio e peridomicílio), com captura de triatomíneos. Foram visitadas 336 casas e os entrevistadores não dispunham de informações sobre os resultados sorológicos e de nenhuma hipótese do estudo, para evitar tendenciosidades na coleta de informações. Além das informações sociais e demográficas, uma história completa com detalhes de migração, condições da habitação (tipo de material das paredes, teto e piso) e residência anterior em locais sabidamente de transmissão da doença de Chagas foi registrada, a fim de se presumir o local da infecção para os casos não autóctones da região. Características da residência atual, como número de cômodos e de pessoas, informações relativas ao uso de lenha, presença de animais (galinha, cão, porco, gato, roedores) na moradia, estocagem de alimentos dentro da habitação e entulhos (lenha, telha, tijolo, pedra) no ambiente doméstico e peridoméstico foram registrados. Presença de anexos (galinheiro/chiqueiro/curral/paiol), palmeiras e ninho de graveteiro-joão graveto (Phacellodomus ruffifrons) nos arredores foram também pesquisados.

Presença de vetores - No momento da visita domiciliar, uma preparação em acrílico, contendo triatomíneos hemípteros hematófagos (triatomíneos), fitófagos e predadores, numerados de 1 a 8 , era mostrada ao proprietário da moradia e solicitado que indicasse o inseto encontrado na residência atual ou em moradias anteriores nos últimos cinco anos. A identificação foi considerada positiva quando o inseto indicado pelo informante era triatomíneo, vetor da doença de Chagas. Quando o informante apontava fitófagos ou predadores a identificação era 
considerada negativa. Todos os domicílios e peridomicílios das crianças soropositivas (casos) e soronegativas (controles) foram inspecionados por investigadores que desconheciam o resultado da sorologia das crianças participantes do estudo. A captura de triatomíneo incluiu a inspecção ativa, com auxílio de lanterna e desalojantes (lambda-cialotrina 3\%), no intradomicílio, em paredes, móveis, telhado e debaixo e através de artefatos domésticos e, no peridomicílio, em galinheiros, pocilgas, paiol e montes de lenha, telha e tijolos. Vestígios de triatomíneos foram também pesquisados no ambiente doméstico e peridoméstico, registrando-se presença de exúvias, cório e fezes (Figuras 4.7-1 e 4.7-2). Os triatomíneos capturados eram acondicionados em frascos de polietileno preparados de acordo com Silva (1985) e enviados ao Laboratório de Parasitologia/IPTESP para identificação da espécie e determinação do índice natural de infecção pelo T. cruzi. A identificação dos triatomíneos foi feita pelas chaves de Lent \& Wygodzinsky (1979) e a infecção foi determinada por coproscopia, usando-se o método das dejeções espontâneas (Silva, 1990), com leituras aos 30, 60 e 90 dias.

Para efeito de vigilância e controle de vetores na região, todas as unidades domiciliares dos 3 municípios do estudo foram inspeccionadas entomologicamente utilizando-se a mesma metodologia. Este procedimento possibilitou o cálculo dos índices de infecção (IInfc) para domicílio, peridomicílio e comunidade, e o índice de infestação (IInft) para comunidade no ano de 1991. Para o cálculo dos referidos índices, utilizaram-se as seguintes fórmulas (OPS, 1978):

$$
\begin{aligned}
& \text { Infc }=\frac{\mathrm{n}^{\circ} \text { triatomíneos positivos }}{\mathrm{n}^{0} \text { triatomíneos examinados }} \times 100, \text { para cada casa investigada; } \\
& \text { Inft }=\frac{\mathrm{n}^{\circ} \text { habitações positivas }}{\mathrm{n}^{0} \text { habitações examinadas }} \times 100, \text { para cada cidade investigada }
\end{aligned}
$$

Outras variáveis de exposição foram definidas como: 
Residência em área endêmica - o local provável de infecção, considerando os municípios de estudo, outros municípios do Estado de Goiás ou outros estados, foi definido como o local da primeira residência em área rural. Para avaliar a extensão da exposição para o risco de reinfecção pelo T. cruzi, o tempo de moradia em áreas de transmissão potencial para doença de Chagas foi estimado para cada criança, somando-se o número total de anos de residência em áreas rurais de regiões endêmicas em habitações com paredes e tetos com qualquer dos seguintes materiais: adobe, folhas de palmeiras/buriti/indaiá/guariroba, pau-a-pique e madeira.

Soropositividade dos pais - uma amostra de sangue foi colhida dos pais para realização de testes sorológicos para detecção de anticorpos anti-T. cruzi utilizandose os mesmos critérios de positividade e negatividade adotados para definição de casos e controles. A soropositividade detectada nas mães dos casos e dos controles foi utilizada para mensurar a possibilidade de transmissão congênita.

Transfusão de sangue - história de transfusão de sangue acompanhada de doença febril, icterícia, sintomas cardíacos durante os primeiros meses após a transfusão foi investigada na tentativa de identificar casos de presumível transmissão transfusional da infecção.

Antecedentes mórbidos - para estimar diferenças no padrão de morbidade entre os participantes, investigou-se a história de hospitalização e os principais antecedentes mórbidos.

Uma cópia do questionário original é apresentado no Anexo 2.

O aglomerado de soropositividade intramoradia foi calculado como a proporção de pessoas soropositivás na moradia entre o total de pessoas investigadas sorologicamente (punção venosa). Para esta variável de exposição foram estabelecidas três categorias de soropositividade intramoradia: a) baixa: 0 a $33 \%$; b) intermediária: $34 \%$ a $67 \%$; e c) alta: $68 \%$ a $100 \%$. 


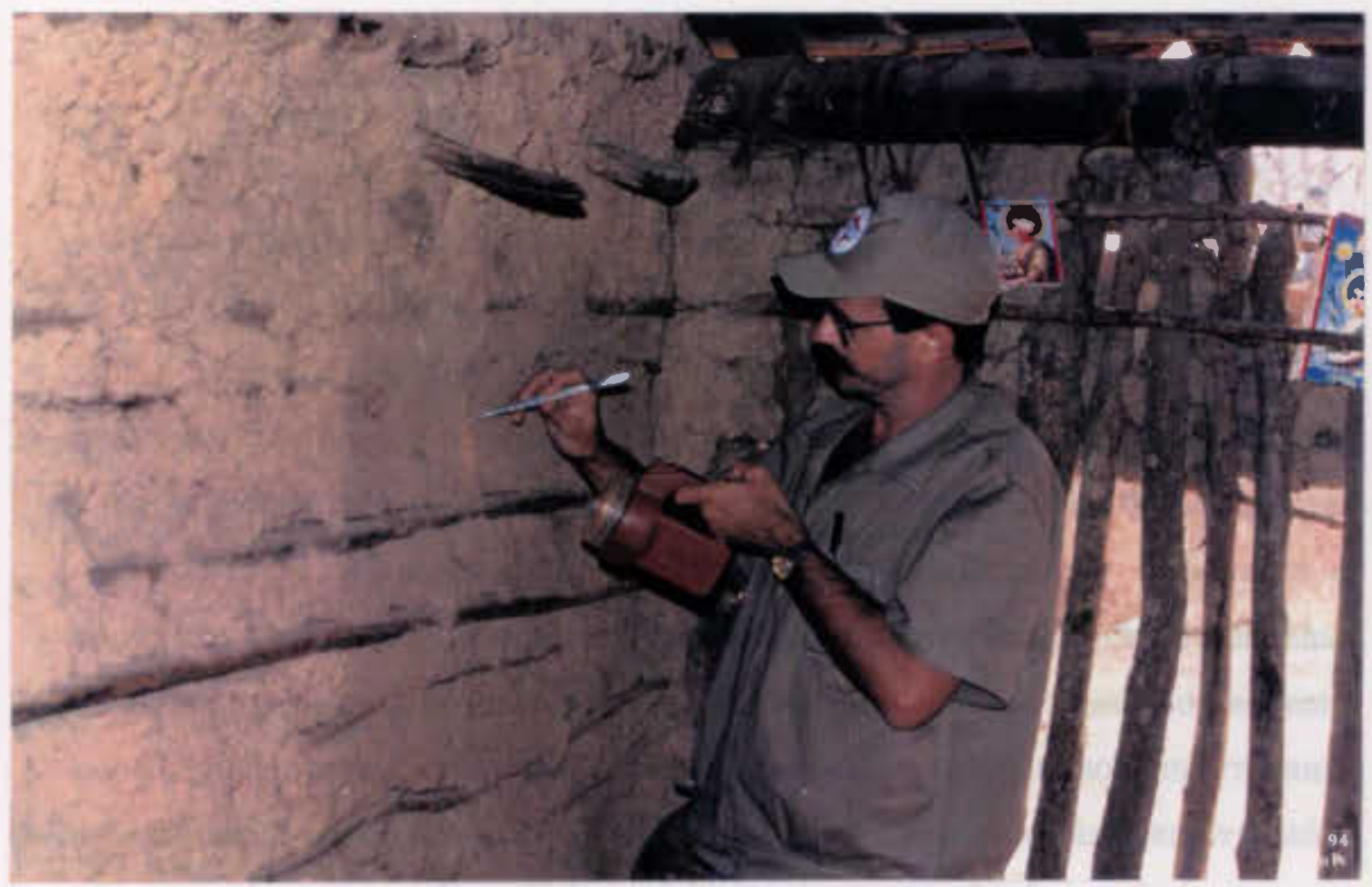

Figura 4.7-1. Captura de triatomíneo na moradia.

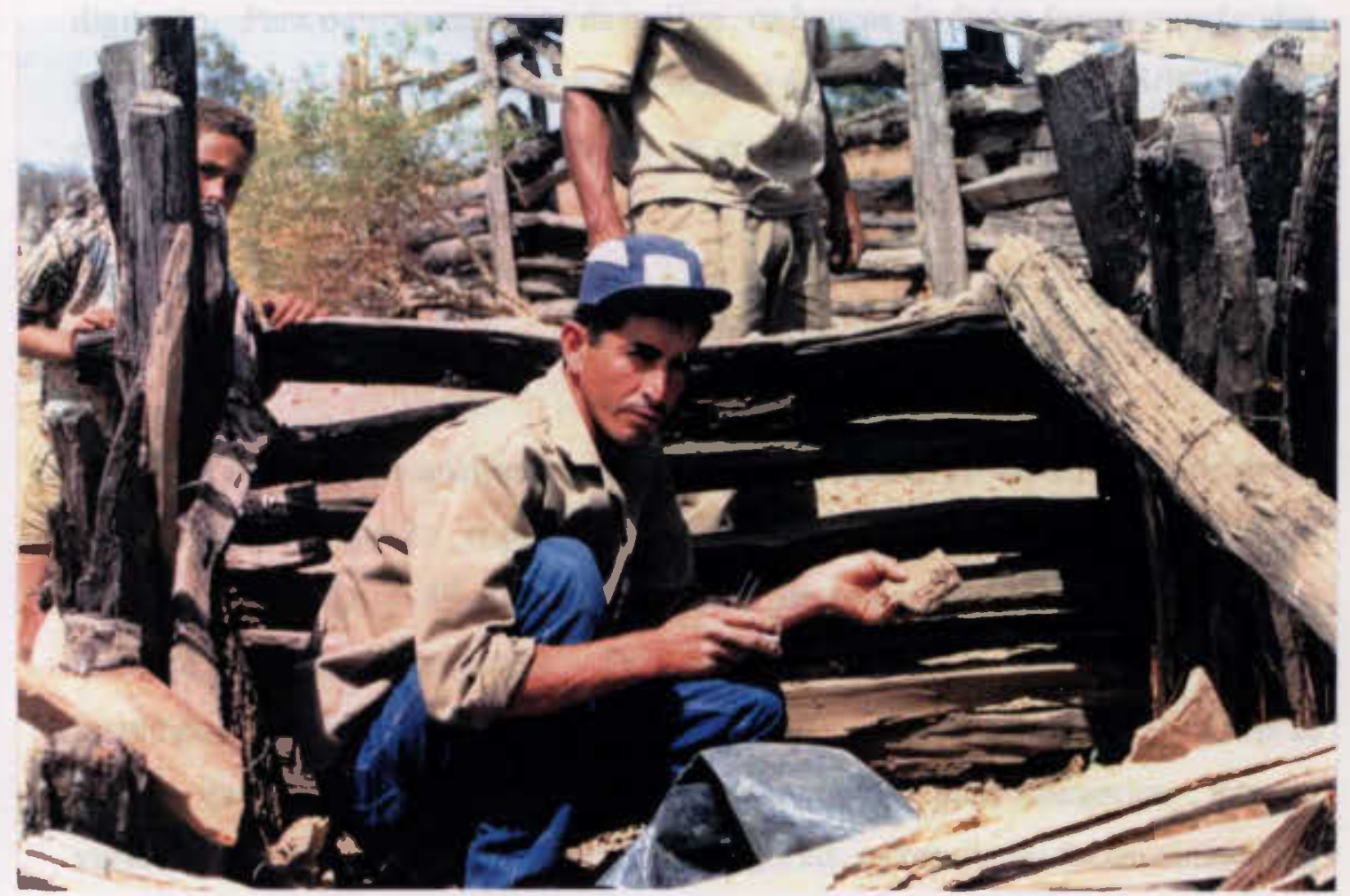

Figura 4.7-2. Pesquisa de triatomíneo em galinheiro prévia à borrifação com inseticida. 


\subsection{Processamento e análise dos dados}

\section{Processamento}

O processamento de dados foi realizado no Departamento de Saúde Coletiva do Instituto de Patologia Tropical e Saúde Pública da Universidade Federal de Goiás. Todos os formulários utilizados no estudo (triagem sorológica, questionários) foram precodificados, de forma compatível para entrada dos dados em microcomputador. A codificação do questionário foi realizada de acordo com o Anexo 3. As informações contidas nos formulários foram codificadas e conferidas diariamente e a seguir armazenadas em banco de dados. O procedimento de digitação foi realizado através de dupla entrada de dados, de forma independente por 2 digitadores, e o controle/verificação de inconsistências utilizou um programa especialmente elaborado. Além desse procedimento, listagens diárias eram obtidas e comparadas com os formulários originais, para correção de possíveis erros de digitação. Para o processamento da análise, os bancos de dados foram transferidos para o programa estatístico Statistical Package for Social Science (SPSS/PC, 1990) para verificar a consistência e realizar os cruzamentos necessários.

\section{Análise dos dados}

A estratégia de análise levou em conta dois bancos de dados, banco de dados 1 e banco de dados 2; o primeiro, referente a 149 casos e 298 controles e o segundo, referente a 89 moradias somente de crianças casos e 278 moradias somente de crianças controles. Para ambos, os dados foram analisados e os resultados apresentados preservando-se o pareamento (caso, controle 1, controle 2) sempre que a variável de exposição era composta por duas categorias. Para as variáveis de exposição com mais de duas categorias, os resultados foram obtidos por regressão logística condicional (RLC) e apresentados de forma não pareada. Para as principais variáveis de exposição relativas ao domicílio e peridomicílio, incluindo 
vetores, variáveis biológicas e sociais, foram calculados odds ratios (OR), levandose em conta o menor nível de exposição como referência $(\mathrm{OR}=1)$.

Casos e controles foram comparados em relação a 3 grupos principais de variáveis: ambiente doméstico, peridoméstico e sorologia dos pais.

O teste t de Student foi utilizado para verificar a significância de diferenças entre médias e testes qui-quadrado foram utilizados para verificar as significâncias de diferenças e de tendência de proporções.

As variáveis de exposição que se mostraram associadas à soropositividade ao T. cruzi foram avaliadas no modelo univariado e multivariado através de regressão logística condicional (RLC). Odds ratio e intervalos de confiança de $95 \%$ foram obtidos utilizando-se o programa EGRET (Epidemiological Graphics, Estimation and Testing Package, Serc, 1991). Odds ratios estratificados por variáveis potenciais de confusão em modelo não condicional foram também calculados empregando-se o método de Mantel-Haenszel (1959) e a diferença entre os odds ratios entre os estratos foi avaliada através do teste de heterogeneidade de Woolf (Breslow \& Day, 1980).

O Anexo 4 mostra a fórmula para o cálculo do odds ratio pareado, utilizado pelo EGRET. O cálculo foi feito considerando somente os triplos discordantes, incluindo, também, as situações em que um dos controles não apresentava informação em relação à variável de estudo (Breslow \& Day, 1980). Utilizou-se como exemplo a Tabela 5.2-1.

As variáveis relacionadas ao domicílio foram: tipo de construção da moradia, número de cômodos e tipo de parede/piso/teto. A habitação foi classificada como ruim quando a apresentava as seguintes características: parede de pau-a-pique ou adobe, teto de barro e piso de terra. As demais combinações de tipo de parede, piso e teto foram consideradas como habitação boa/regular. As variáveis relativas aos 
vetores foram: identificação pelo morador, de triatomíneo na unidade domiciliar, captura de triatomíneo ( $\mathbf{T}$. infestans e $\mathbf{T}$. sordida) no domicílio e anexos e presença de vestígio (exúvias, cório, fezes) na moradia. A identificação de triatomíneo na unidade domiciliar foi considerada positiva quando o informante apontava corretamente os triatomíneos hematófagos contidos em uma preparação de acrílico que incluia também predadores e fitófagos. A moradia foi classificada como infestada quando houve captura de triatomíneo ou presença de vestígios no domicílio. As variáveis do peridomicílio testadas foram: presença de anexos (paiol, chiqueiro, galinheiro), palmeiras, entulhos (lenha, pedras, telhas) e ninho de graveteiro. As variáveis sociais foram avaliadas quanto ao número de pessoas no domicílio, número de pessoas por cômodo, estocagem de alimentos/grãos no ambiente doméstico, montes de lenha e animais (galinhas, cães, porcos, roedores e gatos) na moradia. A soropositividade dos pais ao T. cruzi foi testada como possível fator de risco associado à soropositividade nas crianças.

\subsection{Considerações éticas}

O estudo foi aprovado quanto aos aspectos éticos pelo Comitê Ético da Faculdade de Medicina da Universidade Federal de Goiás e pelo Conselho Regional de Medicina do Estado de Goiás. Todos os familiares dos participantes foram informados dos objetivos da investigação e dos potenciais benefícios, uma vez que o projeto maior ao qual está vinculado o estudo caso-controle prevê a possibilidade de tratamento das crianças soropositivas. Os resultados dos testes sorológicos eram entregues para os pais, em envelopes lacrados, em reunião nas escolas, esclarecendo-se sobre o significado dos resultados. As crianças soropositivas foram referidas para o serviço de saúde local. As medidas de controle de vetores foram estabelecidas para as moradias dos casos e/ou controles onde foram detectados triatomíneos vetores da doença de Chagas. Desta forma, técnicos da FNS procederam à borrifação de todas unidades domiciliares da área de estudo. 


\subsection{Características dos casos e controles}

A comparação de importantes fatores prognósticos entre os dois grupos, casos e controles, que poderiam ter influenciado o resultado do estudo é apresentada nas Tabelas 5.1-1 e 5.1-2, que correspondem aos bancos de dados 1 e 2, respectivamente. A população de estudo consistiu de crianças provenientes de famílias de baixo padrão sócio-econômico, cujos pais ocupavam-se principalmente da lavoura. Devido à estratégia de pareamento adotado no delineamento do estudo, casos e controles apresentaram-se identicamente distribuídos em relação a sexo, idade e local de residência atual.

Para o banco de dados 1 , do total de 149 casos e 289 controles, $59,7 \%$ eram do sexo masculino, com média de idade de 9,9 anos (desvio padrão $=1,6$ ) e 10,0 anos (desvio padrão $=1,7$ ), respectivamente. Somente $10,0 \%$ dos casos e $7,0 \%$ dos controles referiram ter nascido em outros municípios do interior do Estado de Goiás, em geral comunidades vizinhas da área de estudo. O pareamento por escola produziu resultados semelhantes para casos e controles em relação ao local de moradia atual, sendo a maioria dos participantes $(78,5 \%)$ de Posse e o restante igualmente distribuídos entre os municípios de Guarani e Simolândia. A média de pessoas por família nos casos foi significativamente maior (teste $t=2,53 \mathrm{p}=0,01$ ) do que no grupo controle. Cerca de $90 \%$ dos casos e controles nasceram e referiram sempre ter residido na atual moradia, caracterizando uma baixa mobilidade populacional dos habitantes da região. Mais de $90 \%$ das famílias dos casos e controles residiam em casa própria. Não houve diferença estatisticamente significante entre casos e controles quanto aos antecedentes de doença grave, embora a freqüência dessa exposição tenha sido maior no grupo controle. As principais doenças referidas foram desidratação, pneumonia, sarampo, hepatite, desmaios e asma. Cirurgias, desidratação, sarampo e pneumonia foram as causas de hospitalização dos 35 casos e 71 controles (Tabela 5.1-1). 
Tabela 5.1-1.

Número e porcentagem de crianças segundo diversas características e reação sorológica ao Trypanosoma cruzi. Banco de dados 1.

\begin{tabular}{|c|c|c|}
\hline \multirow[b]{2}{*}{ Características } & \multicolumn{2}{|c|}{ Reação Sorológica } \\
\hline & $\underset{\mathbf{n}=149}{(\text { Casos) }}+$ & $\begin{array}{c}\text { (Controles) } \\
n=298\end{array}$ \\
\hline $\begin{array}{c}\text { Idade (anos) } \\
7-9 \\
10-12\end{array}$ & $\begin{array}{l}51(34,2)^{\mathrm{a}} \\
98(65,8)\end{array}$ & $\begin{array}{l}103(34,6) \\
195(65,4)\end{array}$ \\
\hline $\begin{array}{l}\text { Média de idade - anos } \\
\text { desvio padrão }\end{array}$ & $\begin{array}{l}9,9 \\
1,6\end{array}$ & $\begin{array}{c}10,0 \\
1,7\end{array}$ \\
\hline $\begin{array}{l}\text { Sexo } \\
\text { masculino } \\
\text { feminino }\end{array}$ & $\begin{array}{l}89(59,7) \\
60(40,3)\end{array}$ & $\begin{array}{l}178(59,7) \\
120(40,3)\end{array}$ \\
\hline $\begin{array}{l}\text { Local de nascimento } \\
\text { área de estudo } \\
\text { outra área }\end{array}$ & $\begin{array}{r}134(89,9) \\
15(10,1)\end{array}$ & $\begin{array}{r}277(92,9) \\
21(7,1)\end{array}$ \\
\hline $\begin{array}{l}\text { Residência atual } \\
\text { Posse } \\
\text { Guarani } \\
\text { Simolândia }\end{array}$ & $\begin{array}{c}117(78,5) \\
16(10,7) \\
16(10,7)\end{array}$ & $\begin{array}{c}234(78,5) \\
32(10,7) \\
32(10,7)\end{array}$ \\
\hline $\begin{array}{l}\text { Média de pessoas/famíliac } \\
\quad \text { desvio padrão }\end{array}$ & $\begin{array}{l}7,5 \\
2,1\end{array}$ & $\begin{array}{l}6,9 \\
2,3\end{array}$ \\
\hline $\begin{array}{l}\text { Casa própria } \\
\text { sim } \\
\text { não }\end{array}$ & $\begin{array}{c}136(91,3) \\
13(8,7)\end{array}$ & $\begin{array}{r}272(91,3) \\
26(8,7)\end{array}$ \\
\hline $\begin{array}{l}\text { Doença grave } \\
\text { sim } \\
\text { não }\end{array}$ & $\begin{array}{r}23(15,4) \\
123(82,6)\end{array}$ & $\begin{array}{r}59(19,8) \\
234(78,5)\end{array}$ \\
\hline $\begin{array}{l}\text { Hospitalização } \\
\text { sim } \\
\text { não }\end{array}$ & $\begin{array}{r}35(23,5) \\
114(76,5)\end{array}$ & $\begin{array}{r}71(23,8) \\
227(76,2)\end{array}$ \\
\hline
\end{tabular}

${ }^{\mathrm{a}}$ Número em parêntesis $=\%$

${ }^{b}$ teste $\mathrm{t}=0,08 \mathrm{p}=0,9$

c teste $\mathrm{t}=2,53 \mathrm{p}=0,01$

d 8 registros sem informação 
Para o banco de dados 2, que incluiu apenas um participante por moradia, totalizando 89 casos e 178 controles, a maioria também era do sexo masculino (64,0\%), com média de idade de 10,0 anos (desvio padrão $=1,5$ ano). Diferentemente do banco de dados 1, a média de pessoas por família não diferiu estatisticamente entre as casas de criança soropositiva e as casas de criança soronegativa. Quanto às demais variáveis, resultados semelhantes ao banco de dados 1 foram obtidos (Tabela 5.1-2).

\subsection{Avaliação de fatores de risco associados a infecção pelo Trypanosoma cruzi}

Os resultados relativos ao banco de dados 1 serão apresentados, na quase totalidade das vezes, preservando-se os triplos pareados. Com dois controles pareados por caso, as observações representam 149 triplos pareados/caso-controle (caso, controle 1, controle 2). Apenas nas situações em que foi realizada análise estratificada, os dados foram apresentados sob forma não pareada refletindo 149 casos e 298 controles. 
Tabela 5.1-2.

Número e porcentagem de crianças segundo diversas características e reação sorológica ao Trypanosoma cruzi. Banco de dados 2, somente um participante por moradia

Características

Reação sorologica

$\begin{array}{cc}+ \text { (Casos) } \\ \mathrm{n}=89 & -\left(\begin{array}{c}\text { Controles } \\ \mathrm{n}=178\end{array}\right.\end{array}$

Faixa etária

$7-9$

$10-12$

$27(30,3)^{\mathrm{a}} \quad 54(30,3)$

$62(69,7) \quad 124(69,7)$

Média de idade - años desvio padrão

$\begin{array}{rr}10,0 & 10,0 \\ 1,5 & 1,5\end{array}$

Sexo

masculino

feminino

$57(64,0) \quad 114(64,0)$

$32(36,0) \quad 64(36,0)$

Local de nascimento área de estudo outra área

$78(87,6) \quad 167(93,8)$

$11(12,4) \quad 11(6,2)$

Residência atual

Posse

$67(75,3) \quad 140(78,7)$

Guarani

$10(11,2)$

$20(11,2)$

Simolândia

$12(13,5) \quad 10(11,1)$

Média de pessoas/família ${ }^{\mathrm{b}}$ desvio padrão

$\begin{array}{ll}7,1 & 6,7 \\ 2,1 & 2,2\end{array}$

Casa própria

กĩ

$79(88,8) \quad 157(88,2)$

$10(11,2) \quad 21(11,8)$

Doença grave ${ }^{c}$

sim

$15(17,4) \quad 40(22,5)$

não

$71(79,8) \quad 135(75,8)$

Hospitalização ${ }^{d}$

sim

$21(24,1)$

$45(25,6)$

não

$66(74,2)$

$131(73,6)$

a Número em parêntesis $=\%$

b teste $\mathrm{t}=1,38 \mathrm{p}=0,17$

- 6 registros sem informação

d 4 registros sem informação 


\section{a. Presença de vetores}

Das variáveis testadas relativas ao vetor, a que esteve mais associada à soropositividade em crianças foi identificação de triatomíneos pelos moradores nos. últimos 5 anos, na unidade domiciliar. Esta identificação na moradia (OR=3,6 LC $95 \%=1,6-7,8)$, ou nos anexos (OR=2,0 LC 95\% = 1,2-3,3) apresentou odds ratio 7,7 (Tabela $5.2-1$ ).

De acordo com a tabela 5.2-2 (banco de dados 2) a prevalência da identificação de triatomíneos foi alta, tanto para casos, como para controles. Dos 267 entrevistados, $236(88,0 \%)$ referiram ter visto barbeiro nos últimos 5 anos. A identificação de triatomíneos mostrou-se fortemente associada aos casos, tanto em análise univariada $(\mathrm{OR}=6,7 \mathrm{LC} 95 \%=1,6-28,3)$ como multivariada $(\mathrm{OR}=8,7 \mathrm{LC}$ $95 \%=1,4-52,9)$. No entanto, a análise da presença de triatomíneos nos anexos, não confirmou a associação significante encontrada no banco de dados 1 .

Casa infestada, considerada como presença de triatomíneos ou evidências, esteve estatísticamente associada à soropositividade em crianças $(\mathrm{OR}=2,4 \mathrm{LC}$ $95 \%=1,5-3,8)$. Presença de exúvia, $(\mathrm{OR}=3,5 \mathrm{LC} 95 \%=2,1-5,8)$, apresentou maior odds ratio quando comparada à presença de cório ou fezes. A análise isolada da presença/captura de triatomíneo na moradia não esteve associada à infecção pelo T. cruzi em crianças. De acordo com a Tabela 5.2-3, poucos triplos discordantes $(n=29)$ estiveram disponíveis para o cálculo do odds ratio, uma vez que 120 foram concordantes na ausência da exposição. Para o banco de dados 2 , quando se analisou a presença de moradia infestada como fator de risco, somente a presença de exúvia foi confirmada como variável estatisticamente associada a crianças soropositivas, correspondendo a um odds ratio de 2,4 , quando comparada ao grupo controle (Tabela 5.2-4). 
Tabela 5.2-1.

Casos e controles de acordo com número de triplos expostos às variáveis identificação de triatomíneo, domicílio e anexo, com os respectivos odds ratios (OR) pareados e limites de confiança (LC) $95 \%$.

\begin{tabular}{|c|c|c|c|c|}
\hline $\begin{array}{l}\text { Casos } \\
(n=149)\end{array}$ & $\begin{array}{c}\text { Número } \\
0\end{array}$ & $\begin{array}{l}\text { Cont } \\
\text { ( } n=2 \\
\text { ontrc } \\
1\end{array}$ & $\begin{array}{l}\text { expostos } \\
2\end{array}$ & $\begin{array}{l}\mathrm{RLC}^{\mathrm{b}} \\
\text { OR (LC 95\%) }\end{array}$ \\
\hline \multicolumn{5}{|c|}{ Identificação de triatomíneo $^{c}$} \\
\hline não & 0 & 0 & 3 & 1 \\
\hline $\operatorname{sim}$ & 4 & 34 & 106 & $7,7(2,3-25,5)$ \\
\hline \multicolumn{5}{|c|}{ domicílio $^{\mathrm{d}}$} \\
\hline não & 1 & 3 & 5 & 1 \\
\hline $\operatorname{sim}$ & 4 & 43 & 91 & $3,6(1,6-7,8)$ \\
\hline \multicolumn{5}{|c|}{$\operatorname{anexos}^{\circ}$} \\
\hline não & 70 & 23 & 3 & 1 \\
\hline $\operatorname{sim}$ & 23 & 14 & 5 & $2,0(1,2-3,3)$ \\
\hline
\end{tabular}

" Resultados apresentados preservando os 149 triplos (caso, controle1, controle2)

${ }^{b}$ RLC $=$ Regressão logística condicional

' Informação fornecida pelo morador referente a presença de barbeiro na moradia ou anexos nos últimos 5 anos.

147 triplos ( 3 registros sem informação)

d 147 triplos ( 5 registros sem informação)

- 138 triplos (20 registros sem informação) 
Tabela 5.2-2.

Casos e controles de acordo com número de triplos expostos à variável identificação de triatomíneo, domicílio e anexos, com os respectivos odds ratios (OR) pareados e limites de confiança (LC) de 95\%. Banco de dados 2, somente um participante por moradia.

\begin{tabular}{|c|c|c|c|c|c|}
\hline \multirow[b]{2}{*}{$\begin{array}{l}\text { Casos } \\
(\mathrm{n}=89)\end{array}$} & \multicolumn{3}{|c|}{$\begin{array}{c}\text { Controles } \\
(n=178) \\
\text { Número de controles exposto }\end{array}$} & \multicolumn{2}{|c|}{$\mathrm{RLC}^{\mathrm{a}}$} \\
\hline & 0 & 1 & 2 & OR (LC 95\%) & OR (LC 95\%) \\
\hline \multicolumn{6}{|c|}{ 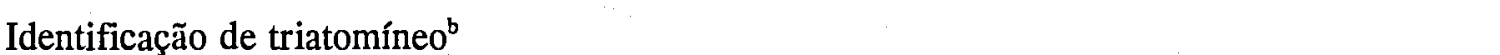 } \\
\hline não & 0 & 0 & 2 & 1 & 1 \\
\hline $\operatorname{sim}$ & 1 & 25 & 59 & $6,7(1,6-28,3)$ & $8,7(1,4-52,9)^{d}$ \\
\hline \multicolumn{6}{|c|}{ domicílio $^{c}$} \\
\hline não & 0 & 4 & 3 & 1 & 1 \\
\hline $\operatorname{sim}$ & 2 & 29 & 49 & $2,8(1,2-6,5)$ & $2,5(1,0-5,8)^{d}$ \\
\hline \multicolumn{6}{|c|}{ anexos ${ }^{e}$} \\
\hline não & 38 & 17 & 3 & 1 & 1 \\
\hline $\operatorname{sim}$ & 13 & 9 & 1 & $1,5(0,8-2,8)$ & $1,5(0,8-3,1)^{d}$ \\
\hline
\end{tabular}

RLC = Regressão logística condicional

b 3 sem informação. Informação fornecida pelo morador referente à presença de barbeiro no domicílio ou nos anexos nos últimos 5 anos

c 4 sem informação

d Ajustados entre si quando apropriado

- 15 sem informação 
Tabela 5.2-3.

Casos e controles de acordo com número de triplos expostos à variável moradia infestada, presença de triatomíneo, exúvia, cório e fezes, com os respectivos odds ratios (OR) pareados e limites de confiança (LC) de $95 \%^{a}$.

\begin{tabular}{|c|c|c|c|c|}
\hline $\begin{array}{l}\text { Casos } \\
(n=149)\end{array}$ & \multicolumn{3}{|c|}{$\begin{array}{c}\text { Controles } \\
(\mathrm{n}=298)\end{array}$} & $\begin{array}{l}\mathrm{RLC}^{\mathrm{b}} \\
\text { OR (LC 95\%) }\end{array}$ \\
\hline \multicolumn{5}{|c|}{ Moradia infestada $^{c}$} \\
\hline não & 35 & 22 & 9 & 1 \\
\hline $\operatorname{sim}$ & 30 & 35 & 18 & $2,4(1,5-3,8)$ \\
\hline \multicolumn{5}{|c|}{ triatomíneo } \\
\hline não & 120 & 18 & 0 & 1 \\
\hline $\operatorname{sim}$ & 7 & 4 & 0 & $1,0(0,5-2,2)$ \\
\hline \multicolumn{5}{|c|}{ exúvia } \\
\hline não & 71 & 17 & 5 & 1 \\
\hline $\operatorname{sim}$ & 36 & 16 & 4 & $3,5(2,1-5,8)$ \\
\hline \multicolumn{5}{|c|}{ cório } \\
\hline não & 84 & 18 & 4 & 1 \\
\hline $\operatorname{sim}$ & 28 & 14 & 1 & $2,8(1,6-4,7)$ \\
\hline \multicolumn{5}{|c|}{ fezes } \\
\hline não & 66 & 27 & 2 & 1 \\
\hline $\operatorname{sim}$ & 19 & 23 & 12 & $1,9(1,1-3,1)$ \\
\hline
\end{tabular}

- Resultados apresentados preservando os 149 triplos (caso, controle1, controle2)

${ }^{\mathrm{b}} \mathrm{RLC}=$ Regressão logística condicional

${ }^{c}$ Moradia infestada $=$ presença de triatomíneo ou vestígios (exúvia, cório, fezes) 
Tabela 5.2-4.

Casos e controles de acordo com número de triplos expostos à variável moradia infestada, exúvia, cório e fezes, com os respectivos odds ratios (OR) pareados e limites de confiança (LC) de $95 \%$. Banco de dados 2, somente um participante por moradia.

\begin{tabular}{|c|c|c|c|c|c|}
\hline \multirow[b]{2}{*}{$\begin{array}{l}\text { Casos } \\
(n=89)\end{array}$} & \multicolumn{4}{|c|}{$\begin{array}{l}\text { Controles } \\
\qquad(n=178)\end{array}$} & $\mathrm{C}^{\mathrm{a}}$ \\
\hline & 0 & 1 & 2 & OR (LC 95\%) & OR (LC 95\%) \\
\hline \multicolumn{6}{|c|}{ Moradia infestada ${ }^{b}$} \\
\hline não & 21 & 11 & 12 & 1 & 1 \\
\hline $\operatorname{sim}$ & 18 & 19 & 8 & $1,6(0,9-2,9)$ & $1,6(0,9-2,9)^{\mathrm{c}}$ \\
\hline \multicolumn{6}{|c|}{ Exúvia } \\
\hline não & 44 & 15 & 1 & 1 & 1 \\
\hline $\operatorname{sim}$ & 24 & 4 & 1 & $3,1(1,7-5,8)$ & $2,4(1,1-4,7)^{d}$ \\
\hline \multicolumn{6}{|l|}{ Cório } \\
\hline กão & 51 & 15 & 3 & 1 & 1 \\
\hline $\operatorname{sim}$ & 18 & 2 & 0 & $1,9(1,0-3,6)$ & $1,3(0,5-3,7)^{d}$ \\
\hline \multicolumn{6}{|l|}{ Fezes } \\
\hline não & 37 & 17 & 6 & 1 & 1 \\
\hline $\operatorname{sim}$ & 14 & 9 & 6 & $1,3(0,7-2,4)$ & $1,0(0,5-2,2)^{d}$ \\
\hline
\end{tabular}

${ }^{\wedge}$ RLC = Regressão logística condicional

${ }^{\mathrm{b}}$ Moradia infestada $=$ presença de triatomíneos ou vestígios (exúvia, cório, fezes)

- Ajustado por identificação de triatomíneo no domićlio

${ }^{d}$ Ajustados entre si quando apropriado 
Os resultados apresentados na Tabela 5.2-5, levando em conta moradia de caso e moradia de controle, mostram que a captura de barbeiro, quer seja no domicílio quer seja no peridomicílio, não esteve associada a criança infectada, à semelhança do observado para o banco de dados 1 . Na tabela 5.2-3, da mesma forma, não se encontrou associação entre presença de $\mathbf{T}$. infestans na moradia atual e soropositividade da criança. Do total das 267 casas inspeccionadas, em 19 foram encontrados triatomíneos, sendo que $\mathbf{T}$. infestans foi capturado em 14 delas, correspondendo a 11 moradias do grupo controle ( 2 com barbeiro infectado) e 3 moradias de casos. Estes resultados significam um índice de infestação de T. infestans de 5,2\% (14/267). Nas 5 casas restantes foram encontrados T. sordida, todas pertencentes a crianças soronegativas.

\section{b. Características do domicílio}

A Figura 5.2-1 mostra a distribuição do tipo de parede das casas das crianças soropositivas e das soronegativas, havendo predomínio de adobe, com ou sem reboco. Uma grande variedade de material foi utilizado na construção das paredes, havendo, no entanto, um padrão semelhante para as casas de casos e controles, o que implicou valores de odds ratio não significantes estatisticamente $(\mathrm{OR}=1,2$ LC 95\% = 0,8-1,6) conforme observado na Tabela 5.2-6. Da mesma forma, o tipo de teto e piso não esteve associado a criança infectada. A Figura 5.2-2 mostra o tipo de moradia predominante na região.

De acordo com o tipo de parede, teto e piso, as moradias foram classificadas em boa/regular ou ruim, como estratégia para aumentar a detecção de associação de criança soropositiva e tipo de construção. Habitação boa ou regular considerou parede com tijolo e/ou demais variações de materiais, teto com telha de cimento amianto e piso de cimento. Por exclusão, todas as demais variações em relação a parede, teto e piso foram incluídas na categoria ruim. Casas de casos e de controles não diferiram estatisticamente quanto ao tipo de habitação. 
Tabela 5.2-5.

Casos e controles de acordo com número de triplos expostos à variável captura de triatomíneo classificada por unidade domiciliar e espécie de triatomíneo no domicílio e anexo com os respectivos odds ratios (OR) pareados e limites de confiança (LC) de $95 \%$. Banco de dados 2, somente um participante por moradia.

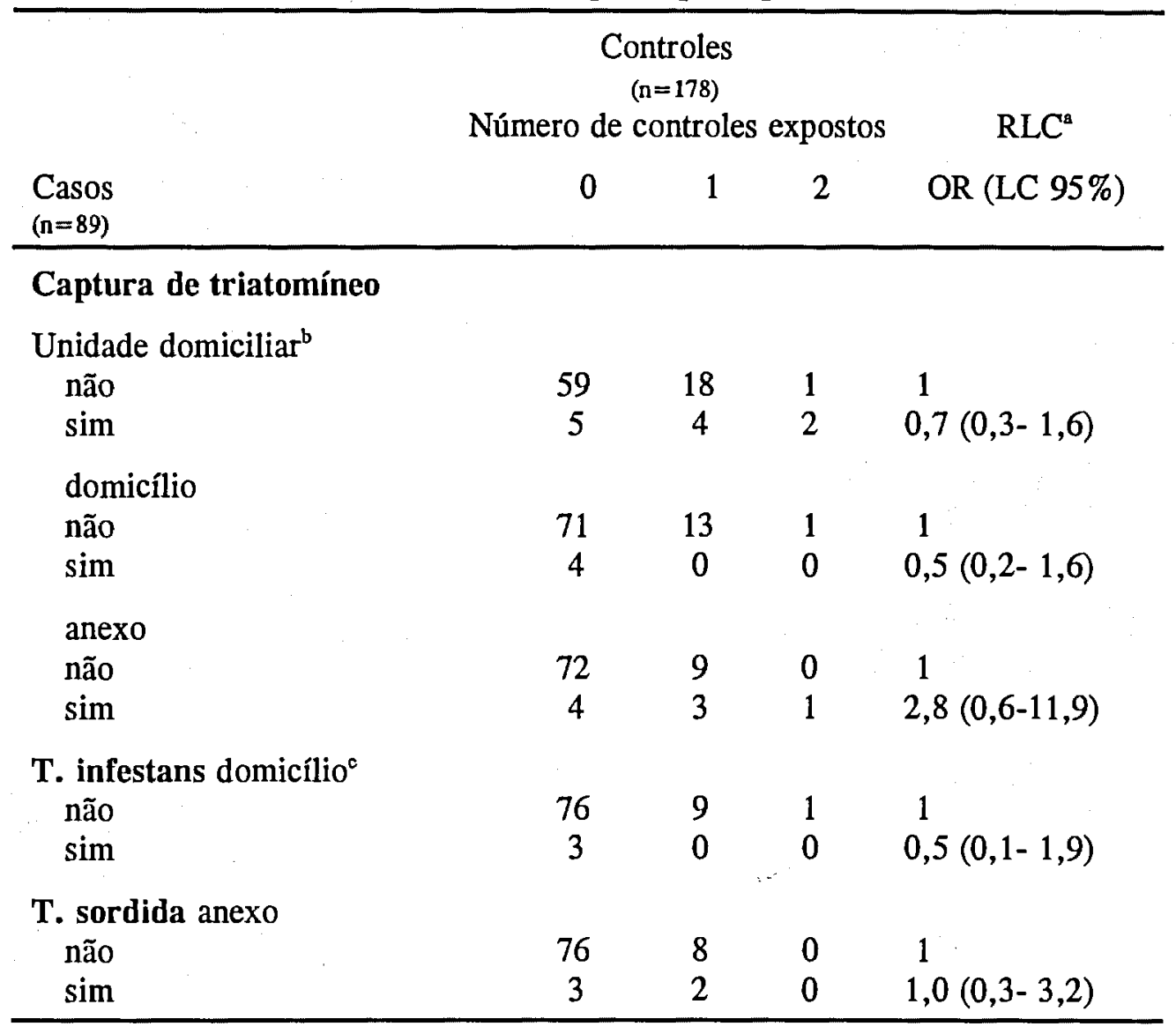

- RLC = Regressão logistica condicional

${ }^{\mathrm{b}}$ Unidade domiciliar = domicllio e anexos

- 2 casas de controles com triatomíneo infectado 
Figura 5.2.1 Distribuição do tipo de parede das 267 casas de casos e controles

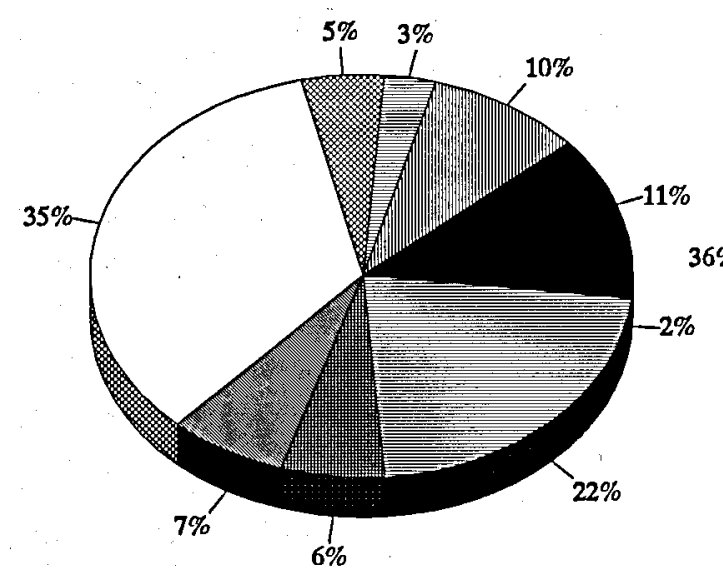

Controles (178)

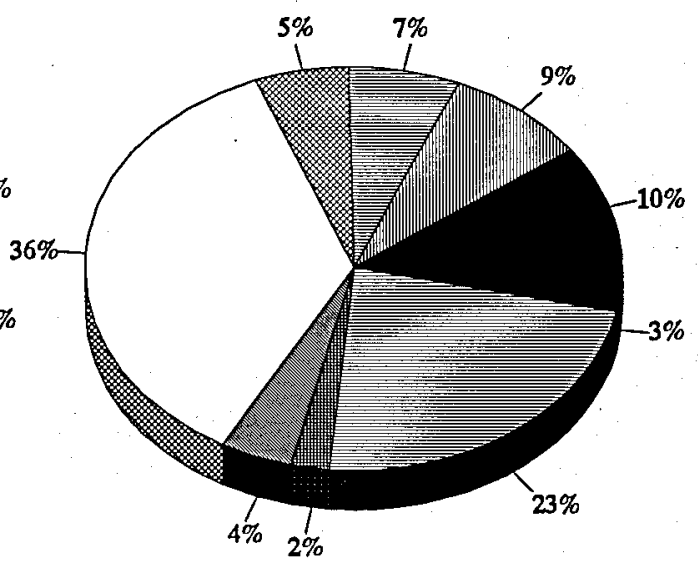

Casos (89)

Tijolo c/ reboco mintijolo s/ reboco Pau-a-pique s/ reboco Madeira $\square$ Adobe s/ reboco Barro $c /$ madeira

睡Tijolo pintada 㞔Adobe c/ reboco $\square$ Outros 
Tabela 5.2-6.

Casos e controles de acordo com número de triplos expostos à variável características do domicílio, classificada por tipo de parede, teto, piso, habitação e número de cômodos, com os respectivos odds ratios (OR) pareados e limites de confiança (LC) de $95 \%$. Banco de dados 2, somente um participante por moradia.

\section{Controles}

$(n=178)$

Número de controles expostos $\quad$ RLC $^{\mathrm{a}}$

\begin{tabular}{llllll}
$\begin{array}{c}\text { Casos } \\
(\mathrm{n}=89)\end{array}$ & 0 & 1 & -2 & OR (LC 95\%) \\
\hline
\end{tabular}

\section{Características do domicílio}

Tipo de parede

tijolo/demais

pau-a-pique/adobe

Tipo de teto ${ }^{c}$

amianto

barro

Tipo de piso ${ }^{d}$

$\begin{array}{lrrrc}\text { cimento } & 3 & 7 & 12 & 1 \\ \text { terra } & 7 & 19 & 37 & 1,1(0,9-1,3)\end{array}$

Tipo de habitação

boa/regular

ruim

$\begin{array}{llll}4 & 8 & 14 & 1\end{array}$

$\begin{array}{llll}7 & 24 & 32 & 1,0\end{array}$

Número de cômodos
$1-3$
$4-6$
$\geq 7$
$\begin{array}{llll}13 & 1 & 0 & 1\end{array}$
$8 \quad 22 \quad 39 \quad 0,9(0,4-1,8)$
$3 \quad 3 \quad 0 \quad 0,3(0,1-1,0)$
$R L$ tendência $(1 g l)^{e}$

${ }^{2}$ RLC = Regressão logística condicional

b 2 registros sem informação

' 2 casas com folha de palmeira, 4 casas com folha de buriti e 2 casas sem informação

d 1 casa com piso de madeira, 4 casas com piso de tijolo e 2 casas sem informação

${ }^{\mathrm{e}} \mathrm{RL}$ tendência $=$ Regressão logística para tendência $\mathrm{gl}=$ grau de liberdade 


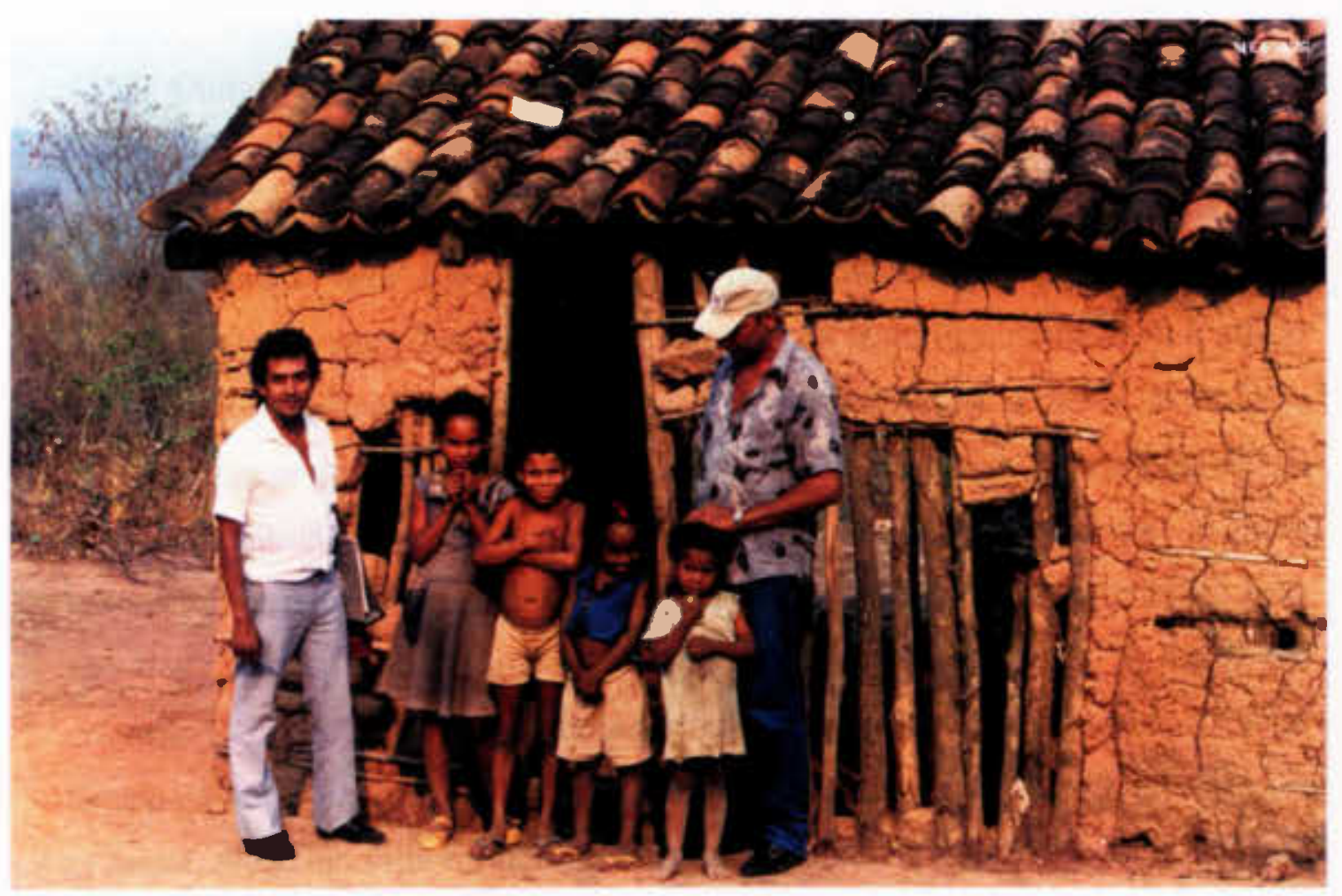

Figura 5.2-2.

Exemplo de moradia da regiâo de estudo. 
O número de cômodos variou de 1 a 13 , observando-se uma tendência decrescente de risco de infecção pelo $T$. cruzi em crianças em relação ao aumento do número de cômodos, o que pode ser mostrado pela regressão linear para tendência com valor de p no limite da significância (Tabela 5.2-6).

Outras características do ambiente doméstico também foram avaliadas, algumas relacionadas a hábitos culturais/comportamentais. Armazenamento de grãos na moradia, após a colheita, é hábito comum na região, o que pode ser visto na Tabela 5.2-7, onde 103 dos 149 triplos foram concordantes na presença dessa exposição. Por outro lado, o armazenamento de lenha dentro da casa é pouco freqüente, obtendo-se 127 triplos concordantes na ausência dessa exposição. Também foram pouco freqüentes presença de cães e porcos dentro do domicílio. Nestas circunstâncias, observou-se uma homogeneidade em relação a essas variáveis, quando se compara casos e controles, o que pode ter contribuído para não deteç̧ão de riscos significativos associados a infecção pelo T. cruzi em crianças soropositivas. Apesar do odds ratio igual a 1,3, a presença de galinhas dentro do domicílio não esteve estatisticamente associada ao risco de infecção em crianças, tendo em vista o valor do intervalo de confiança $95 \%$ obtido $(0,8$ a 2,0$)$. A presença de roedores e gatos também não esteve associada aos casos. Mesmo a estratégia de se testar qualquer tipo de animal na moradia não resultou em detecção de risco. Todas essas variáveis acima descritas foram testadas no banco de dados 2, não se obtendo resultados diferentes em relação aos já mencionados.

\section{c. Características familiares}

Crianças cujas mães eram positivas a anticorpos anti-T. cruzi apresentaram um odds ratio de 3,6 quando comparadas com mães soronegativas, mesmo após ajuste pela idade da mãe, número de pessoas na família e captura de barbeiro na moradia. Diferentemente, soropositividade do pai não esteve estatisticamente associada com filho soropositivo, quer seja em análise univariada quer em multivariada $(\mathrm{OR}=1,6 \mathrm{LC} 95 \%=1,0-2,7)$ (Tabela 5.2-8). 
O cálculo do odds ratio em regressão logística condicional, por sexo e faixa etária, da associação entre soropositividade em crianças e sorologia da mãe é apresentado na Tabela 5.2-9. Crianças do sexo feminino (OR=3,9 LC $95 \%=$ $1,6-9,3)$ e de 10 a 12 anos (OR=3,8 LC 95\% = 1,9-7,6) apresentaram maiores odds ratios, quando comparados com os respectivos estratos de referência. Estes resultados foram confirmados por análise não pareada, estratificada por variáveis potenciais de confusão, relativas à associação entre soropositividade de mães e criança infectada (Tabela 5.2-10). Nenhuma interação foi observada entre os estratos das variáveis sexo e idade, embora semelhantemente aos resultados da análise pareada, sexo feminino e idade 10 a 12 anos apresentassem maiores odds ratios. O resultado da associação de criança infectada e mãe infectada no estrato moradia infestada foi 2 vezes maior $(\mathrm{OR}=4,3 \mathrm{LC} 95 \%=1,8-10,3)$ do que o obtido para moradia não infestada $(\mathrm{OR}=2,2 \mathrm{LC} 95 \%=1,4-4,4)$, porém, não houve evidência estatística de uma modificação de efeito (teste Woolf para heterogeneidade, $X^{2}=1,6, p=0,20$ ). 
Tabela 5.2-7.

Casos e controles de acordo com número de triplos expostos à variáveis relativas ao ambiente doméstico, com os respectivos odds ratio (OR) pareados e limites de confiança (LC) de $95 \%$.

\begin{tabular}{|c|c|c|c|c|}
\hline $\begin{array}{l}\text { Casos } \\
(n=149)\end{array}$ & $\begin{array}{c}\text { Número de } \\
0\end{array}$ & $\begin{array}{c}\text { ontrol } \\
=298) \\
\text { ntrol } \\
1\end{array}$ & $\begin{array}{c}\text { xpostos } \\
2\end{array}$ & $\begin{array}{l}\mathrm{RLC}^{\mathrm{b}} \\
\text { OR (LC 95\%) }\end{array}$ \\
\hline \multicolumn{5}{|c|}{$\begin{array}{l}\text { Armazenamento ali- } \\
\text { mentos na moradia }\end{array}$} \\
\hline กล̃o & 1 & 4 & 12 & 1 \\
\hline $\operatorname{sim}$ & 3 & 26 & 103 & $1,1(0,6-2,1)$ \\
\hline \multicolumn{5}{|c|}{$\begin{array}{l}\text { Armazenamento lenha } \\
\text { na moradia }\end{array}$} \\
\hline não & 127 & 12 & 1 & 1 \\
\hline $\operatorname{sim}$ & 9 & 0 & 0 & $1,3(0,5-3,1)$ \\
\hline \multicolumn{5}{|c|}{ Animais na moradia ${ }^{c}$} \\
\hline não & 3 & 9 & 18 & 1 \\
\hline $\operatorname{sim}$ & 3 & 32 & 84 & $0,8(0,5-1,4)$ \\
\hline \multicolumn{5}{|c|}{ galinhas } \\
\hline กão & 51 & 28 & 13 & 1 \\
\hline $\operatorname{sim}$ & 24 & 19 & 14 & $1,3(0,8-2,0)$ \\
\hline \multicolumn{5}{|l|}{ cães } \\
\hline não & 97 & 16 & 7 & 1 \\
\hline $\operatorname{sim}$ & 10 & 10 & 9 & $1,0(0,5-2,0)$ \\
\hline \multicolumn{5}{|c|}{ porcos } \\
\hline กล̃o & 130 & 8 & 1 & 1 \\
\hline $\operatorname{sim}$ & 3 & 6 & 1 & $1,2(0,4-3,1)$ \\
\hline \multicolumn{5}{|c|}{ roedores } \\
\hline não & 25 & 22 & 20 & 1 \\
\hline $\operatorname{sim}$ & 10 & 32 & 37 & $0,9(0,5-1,3)$ \\
\hline \multicolumn{5}{|l|}{ gatos } \\
\hline กล̃o & 35 & 46 & 15 & 1 \\
\hline $\operatorname{sim}$ & 23 & 22 & 8 & $0,9(0,6-1,3)$ \\
\hline
\end{tabular}

${ }^{4}$ Resultados apresentados preservando os 149 triplos (caso, controle1, controle2)

${ }^{b}$ RLC = Regressão logística condicional

c Änimais = presença de pelo menos um dos seguintes: galinha, cão, porco, roedor,gato 
Tabela 5.2-8.

Casos e controles de acordo com número de triplos expostos a soropositividade dos pais, com os respectivos odds ratios (OR) pareados e limites de confiança (LC) de $95 \%$.

\begin{tabular}{|c|c|c|c|c|c|}
\hline \multirow[b]{2}{*}{ Casos $(n=149)$} & \multicolumn{3}{|c|}{$\begin{array}{l}\text { Controles }(\mathrm{n}=298) \\
\mathrm{N}^{\circ} \text { de controles } \\
\text { expostos }\end{array}$} & \multicolumn{2}{|l|}{$\mathrm{RLC}^{\mathrm{a}}$} \\
\hline & 0 & 1 & 2 & $\mathrm{OR}^{\mathrm{b}}(\mathrm{LC} 95 \%)$ & $\mathrm{OR}^{\mathrm{c}}(\mathrm{LC} 95 \%)$ \\
\hline \multicolumn{6}{|c|}{ Sorologia-mãe } \\
\hline $\begin{array}{l}(-) \\
(+)\end{array}$ & $\begin{array}{r}7 \\
20\end{array}$ & $\begin{array}{l}13 \\
51\end{array}$ & $\begin{array}{c}4 \\
41\end{array}$ & $\begin{array}{l}1 \\
3,6(2,0-6,1)\end{array}$ & $\begin{array}{l}1 \\
3,9 \\
(2,2-6,9)\end{array}$ \\
\hline \multicolumn{6}{|l|}{ Sorologia-paie $^{e}$} \\
\hline $\begin{array}{l}(-) \\
(+)\end{array}$ & $\begin{array}{c}9 \\
26\end{array}$ & $\begin{array}{l}19 \\
32\end{array}$ & $\begin{array}{r}9 \\
29\end{array}$ & $\begin{array}{l}1 \\
1,6(1,0-2,5)\end{array}$ & $\stackrel{1}{1,5}(0,9-, 2,5)$ \\
\hline
\end{tabular}

${ }^{2} \mathrm{RLC}=$ Regressão logística condicional

' Odds ratio não ajustado

' Odds ratio ajustado por idade da mãe, idade do pai, número de pessoas/famflia e presença de triatomíneo na moradia quando apropriado

- 136 triplos (31 registros sem informação)

- 124 triplos (76 registros sem informação) 
Tabela 5.2-9.

Casos e controles de acordo com número de triplos expostos a soropositividade da mãe, segundo sexo e idade, com os respectivos odds ratios (OR) pareados e limites de confiança (LC) de $95 \%$.

\begin{tabular}{|c|c|c|c|c|c|}
\hline \multirow{3}{*}{ Estratos } & \multicolumn{4}{|c|}{ Controles $(n=298)$} & \multirow[b]{2}{*}{ RLC $^{a}$} \\
\hline & & \multicolumn{3}{|c|}{$\mathrm{N}^{0}$ de controles expostos } & \\
\hline & $\begin{array}{l}\text { Casos } \\
(\mathrm{n}=149)\end{array}$ & 0 & 1. & 2 & OR (LC 95\%) \\
\hline & $\begin{array}{c}\text { Sorologi } \\
\text { mãe }\end{array}$ & & & & \\
\hline \multicolumn{6}{|l|}{$\operatorname{Sexo} 0^{b}$} \\
\hline \multirow[t]{2}{*}{ masculino ${ }^{c}$} & $(-)$ & 5 & 8 & 2 & 1 \\
\hline & $(+)$ & 10 & 29 & 27 & $3,5(1,7-7,4)$ \\
\hline \multirow[t]{2}{*}{ feminino $^{d}$} & $(-)$ & 2 & 5 & 2 & 1 \\
\hline & $(+)$ & 10 & 22 & 14 & $3,9(1,6-9,3)$ \\
\hline \multicolumn{6}{|l|}{ Idade $(\operatorname{anos})^{e}$} \\
\hline \multirow[t]{2}{*}{$7-9^{f}$} & $(-)$ & 3 & 5 & 1 & 1 \\
\hline & $(+)$ & 3 & 22 & 17 & $3,1(1,2-7,9)$ \\
\hline \multirow[t]{2}{*}{$10-12^{\mathrm{g}}$} & $(-)$ & 4 & 8 & 3 & 1 \\
\hline & $(+)$ & 17 & 29 & 23 & $3,8(1,9-7,6)$ \\
\hline
\end{tabular}

- RLC = Regressão logística condicional

b 136 triplos (31 registros sem sorologia da mãe)

c 17 registros sem sorologia da mãe

d 14 registros sem sorologia da mãe

e 135 triplos (31 registros sem sorologia da mãe)

' 3 registros sem sorologia da mãe

${ }^{8} 28$ registros sem sorologia da mãe 
Tabela 5.2-10.

Número de casos e controles expostos a soropositividade da mãe, segundo sexo, idade e moradia infestada, com os respectivos odds ratio (OR) e limites de confiança (LC) de $95 \%$.

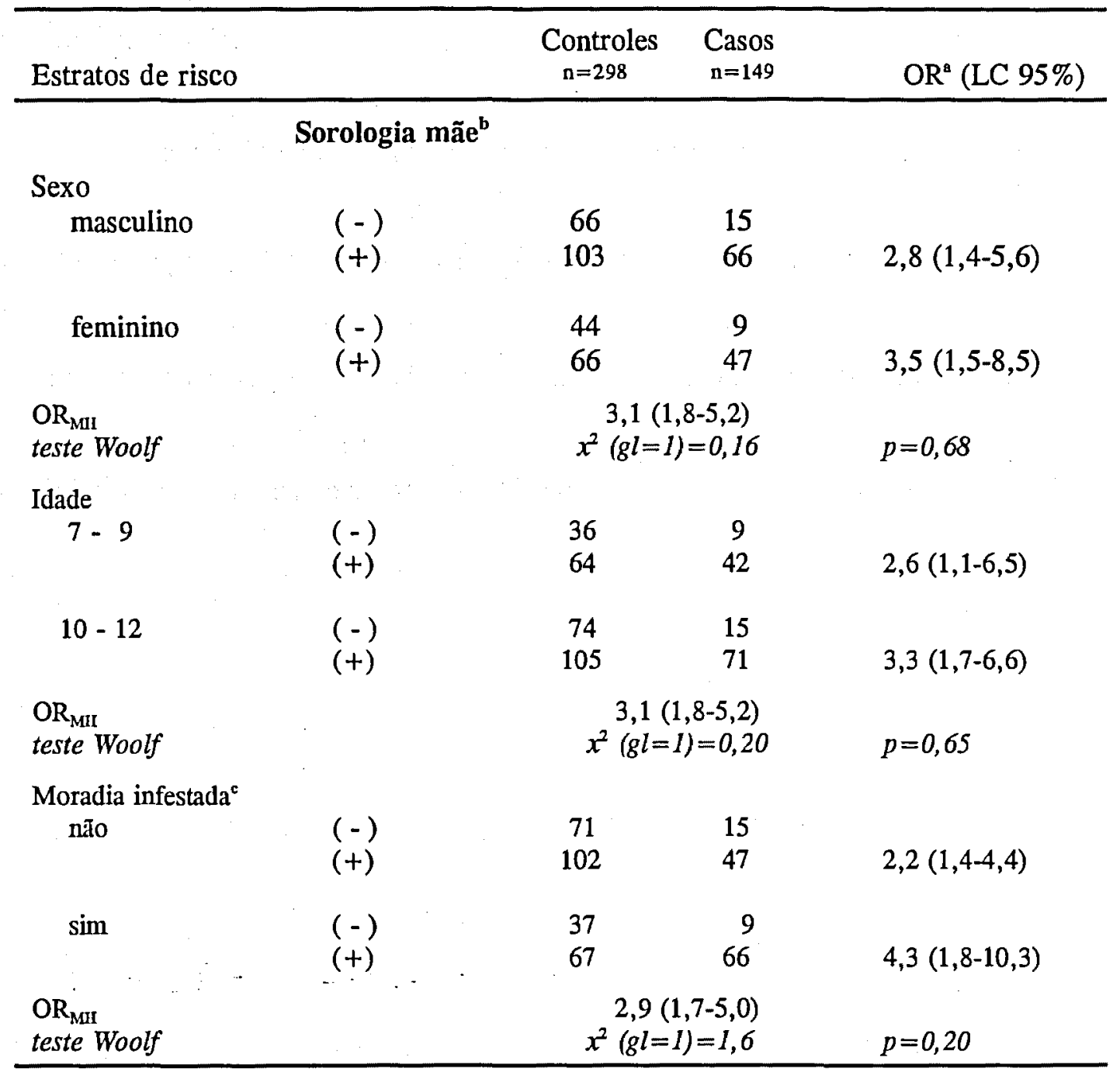

${ }^{a} \mathrm{OR}=$ Odds ratio não condicional

b 31 registros sem informação

${ }^{c}$ Moradia infestada $=$ Triatomíneo ou vestígios (exúvia, cório, fezes) 
Por outro lado, de acordo com a Tabela 5.2-11, uma interação estatística entre sorologia do pai e sorologia da mãe foi encontrada (teste Woolf para heterogeneidade, $\mathrm{X}^{2}=5,5, \mathrm{p}=0,02$ ), indicando uma interação destas variáveis em relação à sorologia da criança. Como ilustrado na Tabela 5.2-11-A, a soropositividade materna apresentou o maior odds ratio de infecção na infância $(\mathrm{OR}=5,2)$, mesmo quando comparado à soropositividade simultânea de ambos, pai e mãe $(O R=4,3)$.

A associação significativa entre mãe soropositiva e criança soropositiva foi também observada quando se analisou o banco de dados 2 , mesmo após ajuste pelas variáveis potenciais de confusão $(\mathrm{OR}=3,4 \mathrm{LC} 95 \%=1,7-6,9)$, enquanto pai soropositivo e filho infectado não estiveram associados (Tabela 5.2-12). Os maiores valores de odds ratio foram encontrados quando ambos os pais eram soropositivos ( $\mathrm{OR}=10,2 \mathrm{LC} 95 \%=2,3-45,5)$, comparativamente aos resultados de apenas um dos pais soropositivos (OR=9,9 LC 95\% $=2,1-45,9)$. 
Tabela 5.2-11.

Número de casos e controles expostos à soropositividade da mãe estratificado por sorologia do pai, com os respectivos odds ratios (OR) não pareados e limites de confiança (LC) de $95 \%$.

\begin{tabular}{ccccc}
\hline Estratos de risco & $\ldots-$ & $\begin{array}{c}\text { Controles } \\
\mathrm{n=298}\end{array}$ & $\begin{array}{c}\text { Casos } \\
\mathrm{n=149}\end{array}$ & OR $^{\mathrm{a}}(\mathrm{LC} 95 \%)$ \\
\hline & Sorologia mãe $^{\mathrm{b}}$ & & \\
Sorologia - paic & & & & \\
negativa & $(-)$ & 60 & 9 & $5,2(2,0-13,0)$ \\
& $(+)$ & 33 & 26 & \\
positiva & $(-)$ & 33 & 15 & $1,4(0,7-2,9)$ \\
& $(+)$ & 111 & 71 & $p=0,02$
\end{tabular}

Tabela 5.2-11-A Odds ratio da sorologia de mãe e pai.

\begin{tabular}{cccc} 
& & \multicolumn{2}{c}{ Sorologia mãe } \\
& $(-)$ & $(-)$ & $(+)$ \\
\hline & $(+)$ & 5,2 \\
Sorologia pai & $(+)$ & 4,3 \\
\hline
\end{tabular}

$\mathrm{OR}=$ Odds ratio

- 31 registros sem informação

c 89 registros sem informação 
Tabela 5.2-12.

Casos e controles de acordo com número de triplos expostos à soropositividade dos pais, com os respectivos odds ratios (OR) pareados e ajustados por variáveis de confusão e limites de confiança (LC) de $95 \%$. Banco de dados 2 , somente um participante por moradia.

\section{Controles}

$(n=178)$

Número de controles expostos

$\mathrm{RLC}^{\mathrm{b}}$

$\begin{array}{lllllll}\text { Casos } & 0 & 1 & 2 & \mathrm{OR}(\mathrm{LC} 95 \%) & \mathrm{OR}^{\mathrm{c}}(\mathrm{LC} \text { 95\%) }\end{array}$

$(\mathrm{n}=89)$

\section{Sorologia}

Pais $^{d}$

ambos ( - )

um deles $(t)$

ambos $(t)$

$\begin{array}{rcccc}1 & 1 & 0 & 1 & 1 \\ 8 & 20 & 5 & 7,3(2,1-25,6) & 9,9(2,1-45,9) \\ 13 & 13 & 5 & 7,6(2,2-26,5) & 10,2(2,3-45,5)\end{array}$

Mãe

$\begin{array}{lrrrcc}(-) & 6 & 10 & 1 & 1 & 1 \\ (+) & 12 & 34 & 17 & 3,6(1,8-7,2) & 3,4(1,7-6,9)\end{array}$

$\mathrm{Pai}^{\mathrm{f}}$

$(-)$

$\begin{array}{llllll}6 & 8 & 8 & 1 & 1\end{array}$

$(+)$

$12 \quad 22 \quad 14 \quad 1,5(0,8-2,9) \quad 1,5(0,8-2,9)$

a Sorologia positiva $(+)=$ pelo menos 2 testes sorológicos positivos

Sorologia negativa $(-)=$ três testes sorológicos negativos

${ }^{b}$ RLC = Regressão logística condicional

c Odds ratio ajustado por idade do pai, idade da mãe e barbeiro ou vestígio no domićlío quando apropriado .

d 26 registros sem informação

- 22 registros sem informação

f 47 registros sem informação 
A despeito das limitações do banco de dados 2, com menor tamanho da amostra, a utilização destes dados apresentou como vantagem a possibilidade de se calcular outros indicadores. De acordo com a Tabela 5.2-13 a inclusão de apenas um participante por família, aliado ao fato de tratar-se de estudo casocontrole populacional, viabilizou a utilização de estimativas de soroprevalência de infecção obtidas em mães e em pais, no grupo controle, respectivamente $56 \%$ (92 $\div$ 165) e $59 \%(88 \div 148)$ como representativas da soropositividade de mulheres e homens da área de estudo (Hennekens \& Buring, 1987; Rodrigues \& Kirkwood, 1990). Possibilitou, também, o cálculo da sensibilidade de algumas variáveis de interesse na detecção de famílias de casos mostrando que os maiores riscos de infecção corresponderam aos maiores índices de sensibilidade. Ainda em relação à Tabela 5.2-13 somente 2 casas de crianças infectadas não seriam detectadas do total das 267, significando uma sensibilidade de $97,7 \%$ quando se utiliza a informação dos moradores referente à presença de vetores na habitação nos últimos 5 anos. A soropositividade dos adultos, pai ou mãe, seria um indicador de casa de criança infectada, de acordo com os valores de sensibilidade calculados para estas variáveis, respectivamente $69,4 \%$ e $78,7 \%$.

Por outro lado, a presença de triatomíneos na moradia apresentou baixa sensibilidade para deteç̧ão de casa de criança soropositiva $(S=4,5 \%)$, obtendo-se valores pouco eficientes mesmo quando associada a presença de vestígios $(S=50,6 \%)$.

Valores crescentes de odds ratio para criança infectada estiveram associados a aumentos do número de pessoas residentes na moradia atual e ao número de pessoas por cômodo (Tabela 5.2-14). Esse fato foi mostrado pelo cálculo da regressão logística para tendência para ambas as variáveis $(p<0,01)$. Detectou-se também que aumentos da proporçã̃o de pessoas soropositivas na família estavam associados a maiores riscos de crianças soropositivas ( $R L$ tendência, $p<0,001$ ). 
A Tabela 5.2-15 analisa os resultados do número de pessoas na habitação e o número de pessoas por cômodo. Embora haja um aumento do odds ratio com o aumento do número de cômodos, esta tendência não se mostrou estatisticamente significante (RL tendência, $\mathrm{p}>0,05$ ). Somente o número de pessoas por cômodo manteve-se associado estatisticamente a criança infectada, quando comparado a criança não infectada. Ainda em relação a este banco de dados, nas moradias dos casos sempre mais de $25 \%$ das pessoas, incluindo os casos, estavam infectadas. Em contrapartida; em 55 moradias de controles nenhuma pessoa estava infectada. Estes resultados podem ser visualizados no histograma apresentado na Figura 5.2-3, que mostra uma concentração das casas dos casos onde uma maior proporção de pessoas soropositivas foram detectadas, diferentemente do padrão observado para as casas de controles. 
Tabela 5.2-13.

Número de casos e controles expostos a variáveis relativas ao vetor e soropositividade dos pais e sensibilidade das variáveis para deteç̧ão de criança soropositiva (caso) e criança soronegativa (controle). Banco de dados 2, somente um participante por moradia

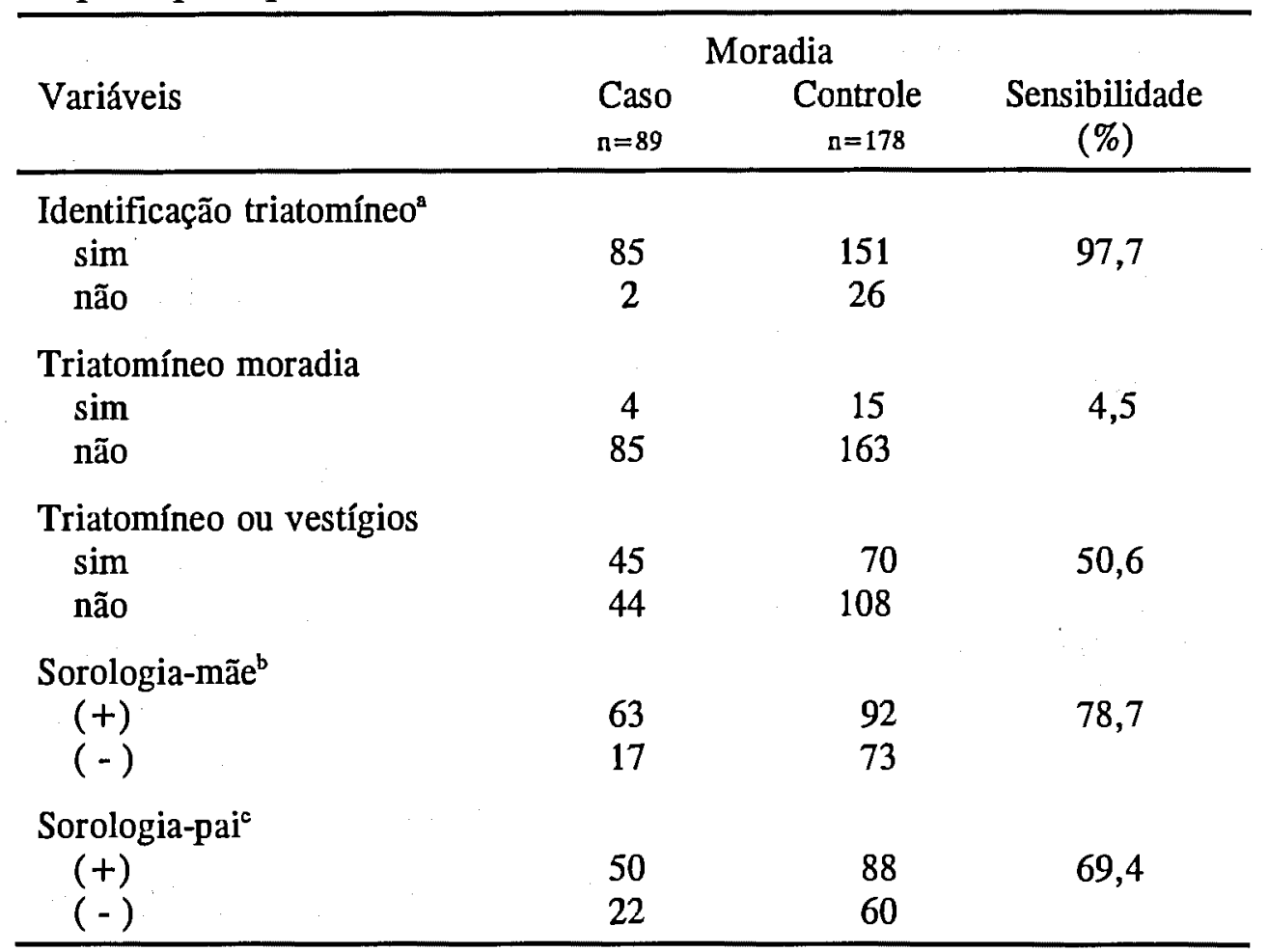

4 3 registros sem informação. Informação fornecida pelo proprietário referente à presença de triatomíneo na moradia ou anexos nos últimos 5 anos

$\checkmark 22$ registros sem informação

c 47 registros sem informação 
Tabela 5.2-14.

Casos e controles de acordo com número de triplos expostos à características familiares com os respectivos odds ratios (OR) pareados e limites de confiança (LC) de $95 \%$.

\section{Controles}

$(n=298)$

Número de controles expostos $\quad$ RLC $^{\mathrm{a}}$

\begin{tabular}{lllll}
$\substack{C a s 0 s \\
(n=149)}$ & 0 & 1 & 2 & $\mathrm{OR}^{\mathrm{b}}(\mathrm{LC} 95 \%)$ \\
\hline
\end{tabular}

\section{Características familiares}

Número de pessoas

\begin{tabular}{|c|c|c|c|c|}
\hline $\begin{array}{l}1-4 \\
5-8 \\
\geq 9\end{array}$ & $\begin{array}{c}5 \\
9 \\
26\end{array}$ & $\begin{array}{c}3 \\
39 \\
15\end{array}$ & $\begin{array}{c}0 \\
49 \\
3\end{array}$ & $\begin{array}{l}1 \\
1,9(0,8-4,3) \\
3,0(1,2-7,5)\end{array}$ \\
\hline$R L$ tendência ${ }^{c}(1 \mathrm{gl})$ & & & & \\
\hline
\end{tabular}

Número de pessoas/cômodo

$\begin{array}{lcccc}<1 & 9 & 3 & 0 & 1 \\ 1-<2 & 11 & 43 & 32 & 2,0(1,0-3,9) \\ \geq 2 & 27 & 22 & 2 & 3,4(1,6-7,1) \\ R L \text { tendência }{ }^{c}(1 \mathrm{gl}) & p<0,001 & & \end{array}$

Aglomerado de soropositividade intramoradia

\begin{tabular}{lrrrc} 
baixo & 0 & 4 & 3 & 1 \\
intermediário & 9 & 20 & 6 & 8,1 \\
alto & 97 & 9 & 1 & $265,6(61,0-1157,0)$ \\
& \\
$R L$ tendência & $(1 g l)$ & $p<0,001$ & & \\
\hline
\end{tabular}

- RLC = Regressão logística condicional

${ }^{\mathrm{b}}$ Odds ratio ajustado por captura de barbeiro e vestígios

${ }^{\circ}$ RL tendência $=$ Regressão logística para tendência

$\mathrm{gl}=$ grau de liberdade 
Tabela 5.2-15.

Casos e controles de acordo com o número de triplos expostos à características sociais com os respectivos odds ratios (OR) pareados e limites de confiança (LC) de $95 \%$. Banco de dados 2 , somente um participante por moradia.

\begin{tabular}{|c|c|c|c|c|}
\hline \multirow[b]{2}{*}{$\begin{array}{l}\text { Casos } \\
(n=89)\end{array}$} & \multicolumn{3}{|c|}{$\begin{array}{c}\text { Controles } \\
(n=178) \\
\text { Número de controles expostos }\end{array}$} & \multirow{2}{*}{$\begin{array}{c}\text { RLC }^{\mathrm{a}} \\
\text { OR }(\mathrm{LC} 95 \%)\end{array}$} \\
\hline & 0 & 1 & 2 & \\
\hline \multicolumn{5}{|c|}{ Características sociais } \\
\hline $\begin{array}{l}\text { Número de pessoas } \\
\begin{array}{l}1-4 \\
5-8 \\
\geq 9\end{array}\end{array}$ & $\begin{array}{c}5 \\
2 \\
12\end{array}$ & $\begin{array}{l}2 \\
2 \\
7\end{array}$ & $\begin{array}{c}0 \\
35 \\
2\end{array}$ & $\begin{array}{l}1 \\
1,5(0,6-3,8) \\
2,1(0,8-5,9)\end{array}$ \\
\hline$R L$ tendência $(I g l)^{b}$ & \multicolumn{3}{|c|}{$p>0,05$} & \\
\hline $\begin{array}{l}\text { Número de pessoas/ } \\
\quad<1 \\
1-<2 \\
\geq 2\end{array}$ & $\begin{array}{c}6 \\
8 \\
16\end{array}$ & $\begin{array}{c}4 \\
27 \\
8\end{array}$ & $\begin{array}{c}0 \\
20 \\
0\end{array}$ & $\begin{array}{l}1 \\
1,7(0,8-3,8) \\
2,6(1,1-6,3)\end{array}$ \\
\hline RL tendência (lgl) & $p=0, c$ & & & \\
\hline
\end{tabular}

${ }^{2}$ RLC $=$ Regressão logística condicional

${ }^{b} \mathrm{RL}$ tendência $=$ Regressão logística para tendência 
Figura 5.2-3 Proporção de pessoas soropositivas nas casas de casos e controles

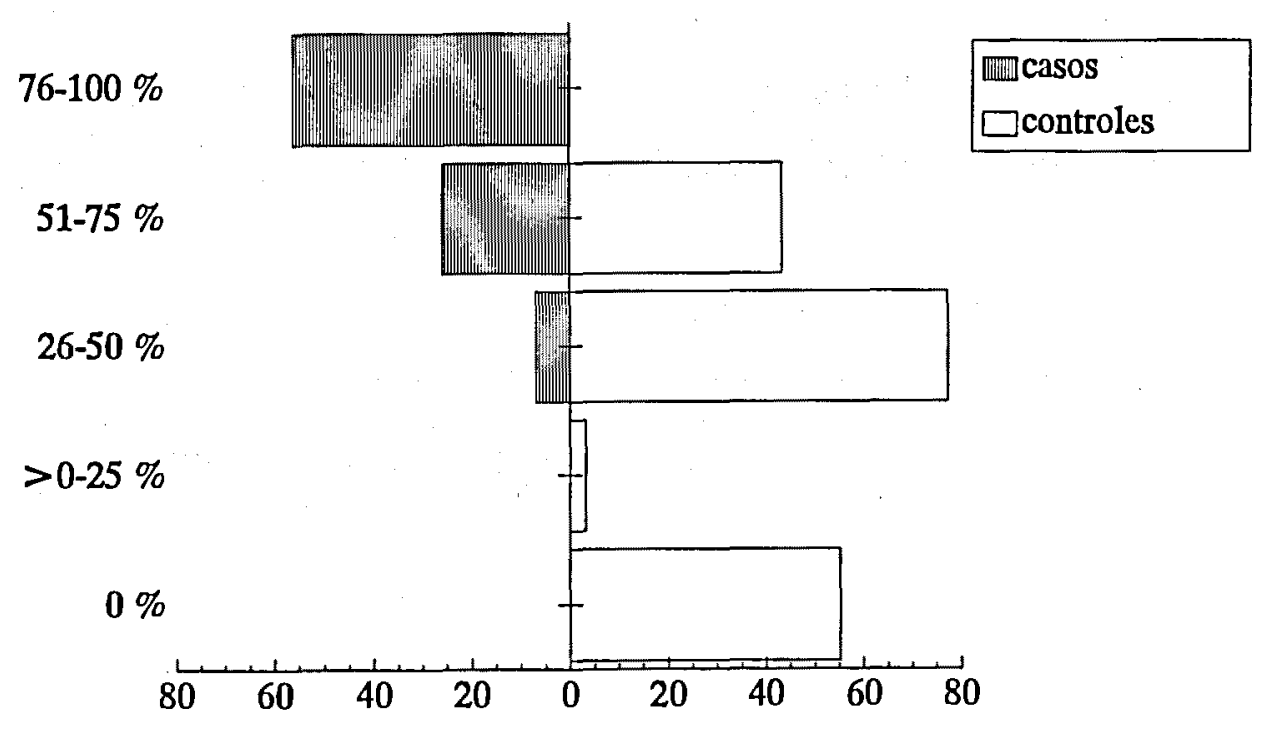

Número de casas 


\section{d. Características do peridomicilio}

Exposições relativas ao ambiente peridoméstico, como presença de anexos, entulhos, palmeiras no lote e ninho de graveteiro (Phacellodomus rufifrons) nos arredores da habitação, foram testadas como possíveis fatores de risco associados à soropositividade de crianças. Os tipos de palmeiras predominantes no peridomílio foram buriti (Mauritia vinifera), guariroba (Syagrus oleracea) e macaúba (Acrocomia sclerocarpa). As Tabelas 5.2-16 e 5.2-17 mostram os odds ratio para estas exposições, respectivamente para os banco de dados $1 \mathrm{e} 2$. Valores elevados de odds ratio foram encontrados em relação à presença de qualquer tipo de anexo e ninho de graveteiro para ambos os bancos de dados e presença de galinheiro para o banco de dados 2. No entanto, estes resultados não foram estatisticamente significantes, com limites de confiança $95 \%$ incluindo o valor unitário. As Figuras 5.2-4, 5.2-5 e 5.2-6 ilustram os tipos de anexos encontrados na região e a Figura 5.2-7 mostra um ninho de joão graveto.

\section{e. Resumo}

Os fatores de risco para infecção pelo T.cruzi em crianças avaliados no estudo foram:

a) Presença de vetores: identificação de triatomíneos, pelo morador, na unidade domiciliar nos últimos 5 anos; moradia infestada e presença de vestígios (exúvias, cório, fezes) no domicílio ou no peridomicílio.

b) Características do domicílio: captura de triatomíneo no domicílio, nos anexos ou em ambos; captura de T.infestans no domicílio; captura de T.sordida no anexo; tipo de parede; tipo de teto; tipo de piso; tipo de habitação (boa/regular ou ruim); número de cômodos; armazenamento de alimentos na moradia; armazenamento de lenha na moradia e presença de animais na moradia (galinhas, cães, porcos, roedores, gatos). 
c) Características familiares: soropositividade das mães; soropositividade dos pais; soropositividade de mãe e pai; número de pessoas na família; número de pessoas por cômodo; aglomerado de soropositividade intramoradia.

d) Características do peridomicílio: presença de qualquer tipo de anexo; presença de paiol; presença de chiqueiro; presença de galinheiro, presença de entulhos; presença de palmeira e presença de ninho de graveteiro nos arredores da moradia.

Um sumário das principais associações encontradas neste estudo incluindo os resultados obtidos nos dois bancos de dados é mostrado na Tabela 5.2-18. Das variáveis de exposição relacionadas ao vetor, presença de triatomíneos ou vestígios (moradia infestada) apenas esteve estatisticamente associada a criança soropositiva no banco de dados 1. A identificação de triatomíneo pelo morador foi considerada fator de risco para infecção na infância no banco de dados 1 e 2 .

Das características do domicílio, somente o aumento do número de cômodos esteve associado aos casos, como fator de proteção para infeç̧̃ao em crianças, com valores limítrofes de significância estatística $(p=0,05)$ em ambos os bancos de dados.

Várias características familiares foram detectadas como fatores de risco para soropositividade em crianças. Mãe soropositiva e filho soropositivo estiveram estatisticamente associados em ambos os bancos de dados, obtendo-se altos valores de odds ratio. $\mathrm{O}$ risco de criança infectada esteve significativamente e crescentemente relacionado a soropositividade de pelo menos um dos pais ou ambos. Também o aumento do número de pessoas por cômodo representou fator de risco para criança infectada, estatisticamente significante em ambos os bancos de dados. O número de pessoas na moradia esteve estatisticamente associado somente à soropositividade da criança, no banco de dados 1 . Finalmente, o aglomerado de pessoas soropositivas na moradia esteve estatisticamente asssociado a riscos crescentes de infecção na infância no banco de dados 1 . 
Tabela 5.2-16.

Casos e controles de acordo com número de triplos expostos à presença de anexos, entulhos, palmeiras e ninho de graveteiro no peridomicílio, com os respectivos odds ratios (OR) pareados e limites de confiança (LC) de $95 \%^{\mathrm{B}}$.

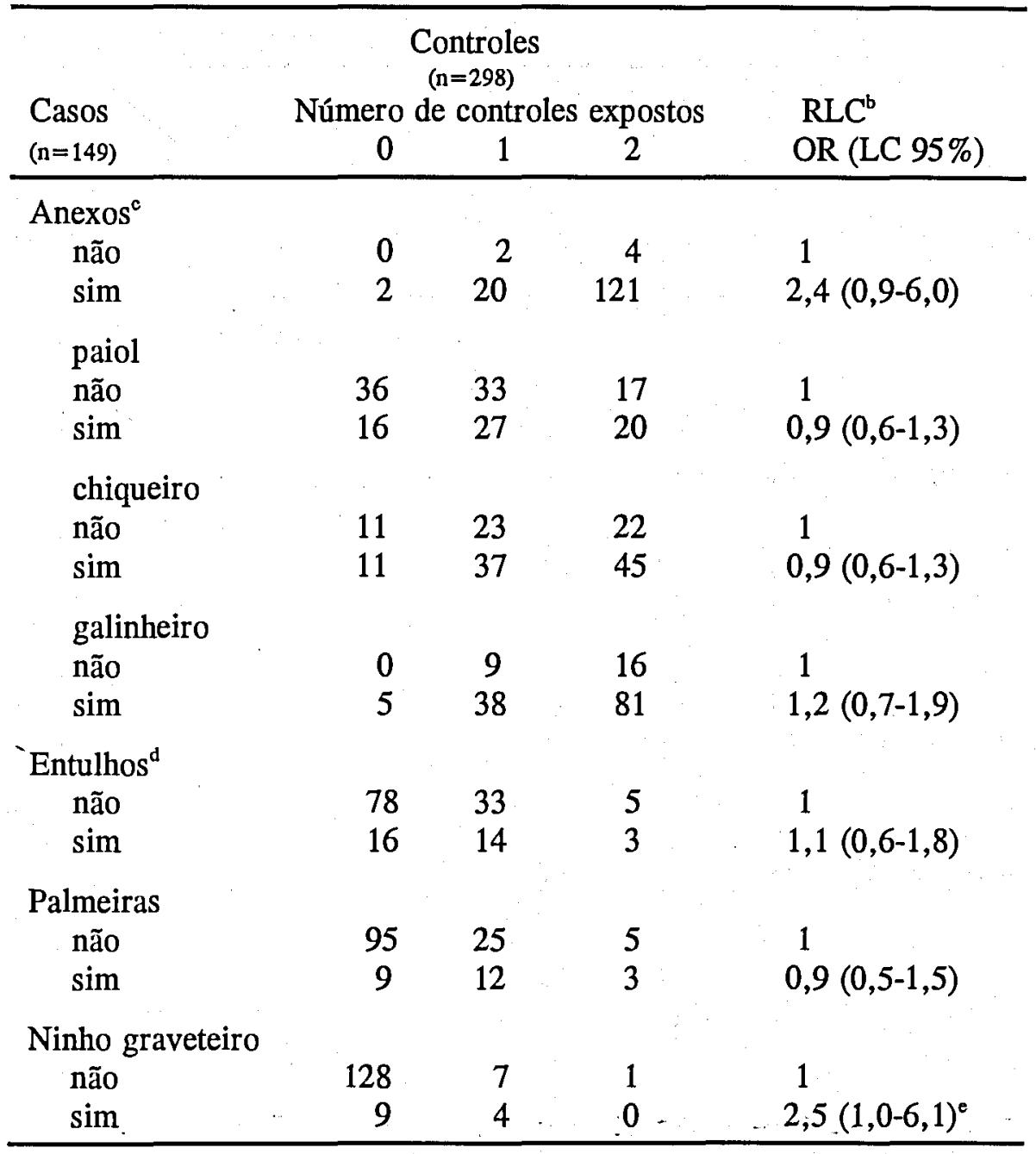

a Resultados apresentados preservando os 149 triplos (caso,controle 1, controle 2)

: RLC = Regressão logística condicional

${ }^{\mathrm{c}}$ Anexos = Presença de pelo menos um dos seguintes: paiol, chiqueiro ou galinheiro

¿Entulho = Presença de pelo menos um dos seguintes: montes de pedras, tijolos, telha ou lenha e $\mathrm{p}=0,05$ 
Tabela 5.2-17.

Casos e controles de acordo com número de triplos expostos à presença de anexos, entulhos, palmeiras e ninho de graveterio no peridomicílio, com os respectivos odds ratios (OR) pareados e limites de confiança (LC) de $95 \%$. Banco de dados 2, somente um participante por moradia.

\begin{tabular}{|c|c|c|c|c|}
\hline \multirow[b]{2}{*}{$\begin{array}{l}\text { Casos } \\
(n=89)\end{array}$} & \multicolumn{3}{|c|}{$\begin{array}{c}\text { Controles } \\
(n=178) \\
\text { Número de controles expostos }\end{array}$} & \multirow{2}{*}{$\begin{array}{c}\mathrm{RLC}^{\mathrm{a}} \\
\text { OR (LC 95\%) }\end{array}$} \\
\hline & 0 & 1 & 2 & \\
\hline \multicolumn{5}{|c|}{ Características do peridomicílio } \\
\hline $\begin{array}{l}\text { Anexos } \\
\text { não } \\
\text { sim }\end{array}$ & $\begin{array}{l}0 \\
2\end{array}$ & $\begin{array}{c}0 \\
16\end{array}$ & $\begin{array}{c}5 \\
66\end{array}$ & $\stackrel{1}{2,1}(0,8-5,8)$ \\
\hline $\begin{array}{l}\text { paiol } \\
\text { não } \\
\text { sim }\end{array}$ & $\begin{array}{c}16 \\
8\end{array}$ & $\begin{array}{l}23 \\
19\end{array}$ & $\begin{array}{l}12 \\
11\end{array}$ & $\begin{array}{c}1 \\
0,7\end{array}(0,4-1,3)$ \\
\hline $\begin{array}{l}\text { chiqu } \\
\text { não } \\
\text { sim }\end{array}$ & $\begin{array}{l}5 \\
9\end{array}$ & $\begin{array}{l}18 \\
19\end{array}$ & $\begin{array}{l}13 \\
25\end{array}$ & $\begin{array}{l}1 \\
1,8(0,5-1,4)\end{array}$ \\
\hline $\begin{array}{l}\text { galin } \\
\text { não } \\
\text { sim }\end{array}$ & $\begin{array}{c}4 \\
22\end{array}$ & $\begin{array}{c}4 \\
22\end{array}$ & $\begin{array}{c}7 \\
49\end{array}$ & $\begin{array}{c}1 \\
2,0(1,0-4,3)^{b}\end{array}$ \\
\hline $\begin{array}{l}\text { Entulho } \\
\text { não } \\
\text { sim }\end{array}$ & $\begin{array}{l}44 \\
11\end{array}$ & $\begin{array}{c}23 \\
7\end{array}$ & $\begin{array}{l}4 \\
0\end{array}$ & $\begin{array}{c}1 \\
0,9(0,5-1,7)\end{array}$ \\
\hline $\begin{array}{l}\text { Palmeir } \\
\text { não } \\
\text { sim }\end{array}$ & $\begin{array}{r}51 \\
9\end{array}$ & $\begin{array}{c}23 \\
3\end{array}$ & $\begin{array}{l}3 \\
0\end{array}$ & $\begin{array}{c}1 \\
0,7(0,3-1,4)\end{array}$ \\
\hline $\begin{array}{l}\text { Ninho } \\
\text { não } \\
\text { sim }\end{array}$ & $\begin{array}{c}74 \\
8\end{array}$ & $\begin{array}{l}6 \\
0\end{array}$ & $\begin{array}{l}1 \\
0\end{array}$ & $\begin{array}{c}1 \\
2,1 \\
(0,7-5,9)\end{array}$ \\
\hline
\end{tabular}

- RLC = Regressão logística condicional ajustada por idade e sexo

${ }^{\mathrm{b}} \mathrm{p}=0,05$ 


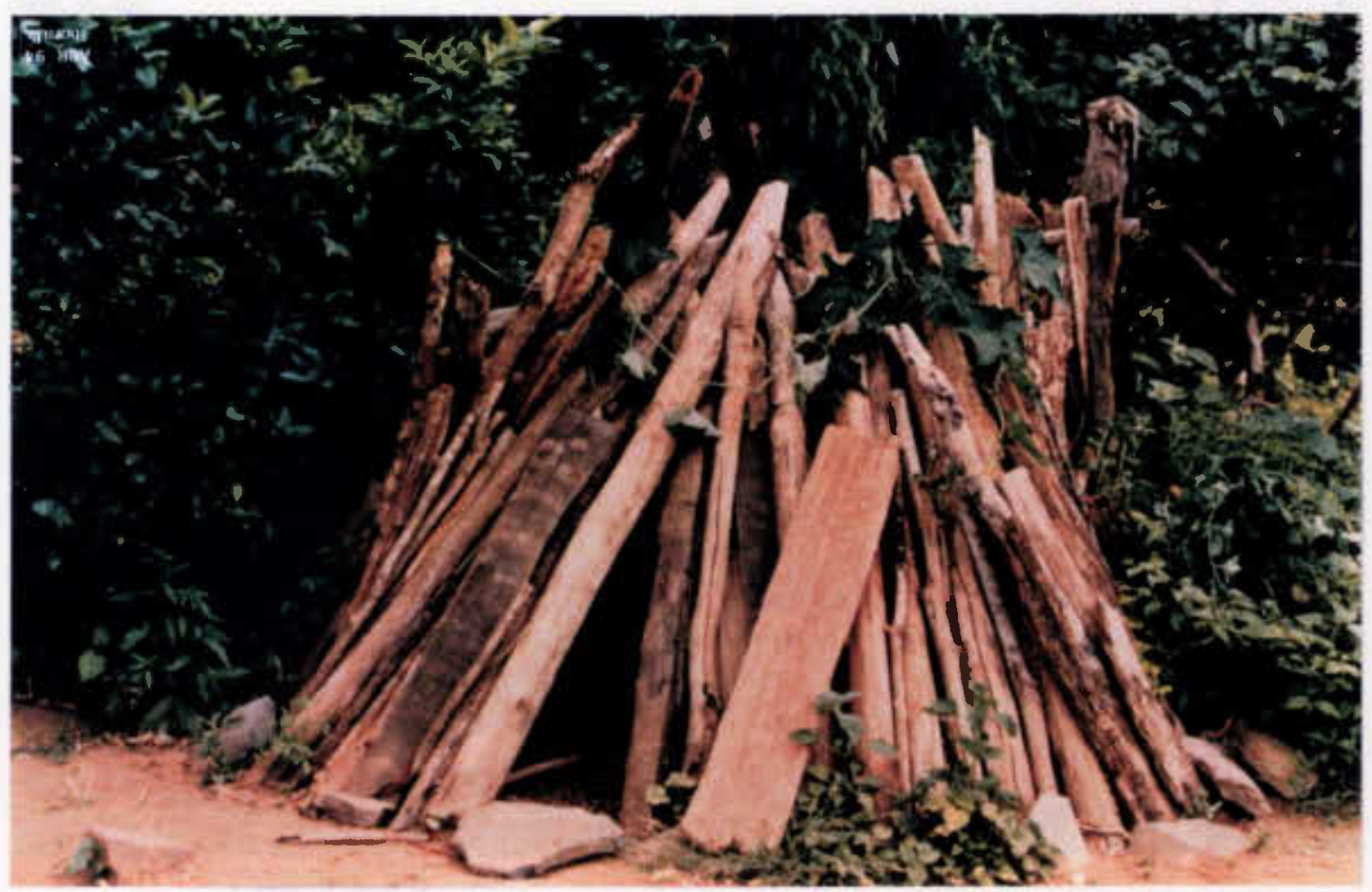

Figura 5.2-4.

Tipo de galinheiro freqüente na região de estudo.

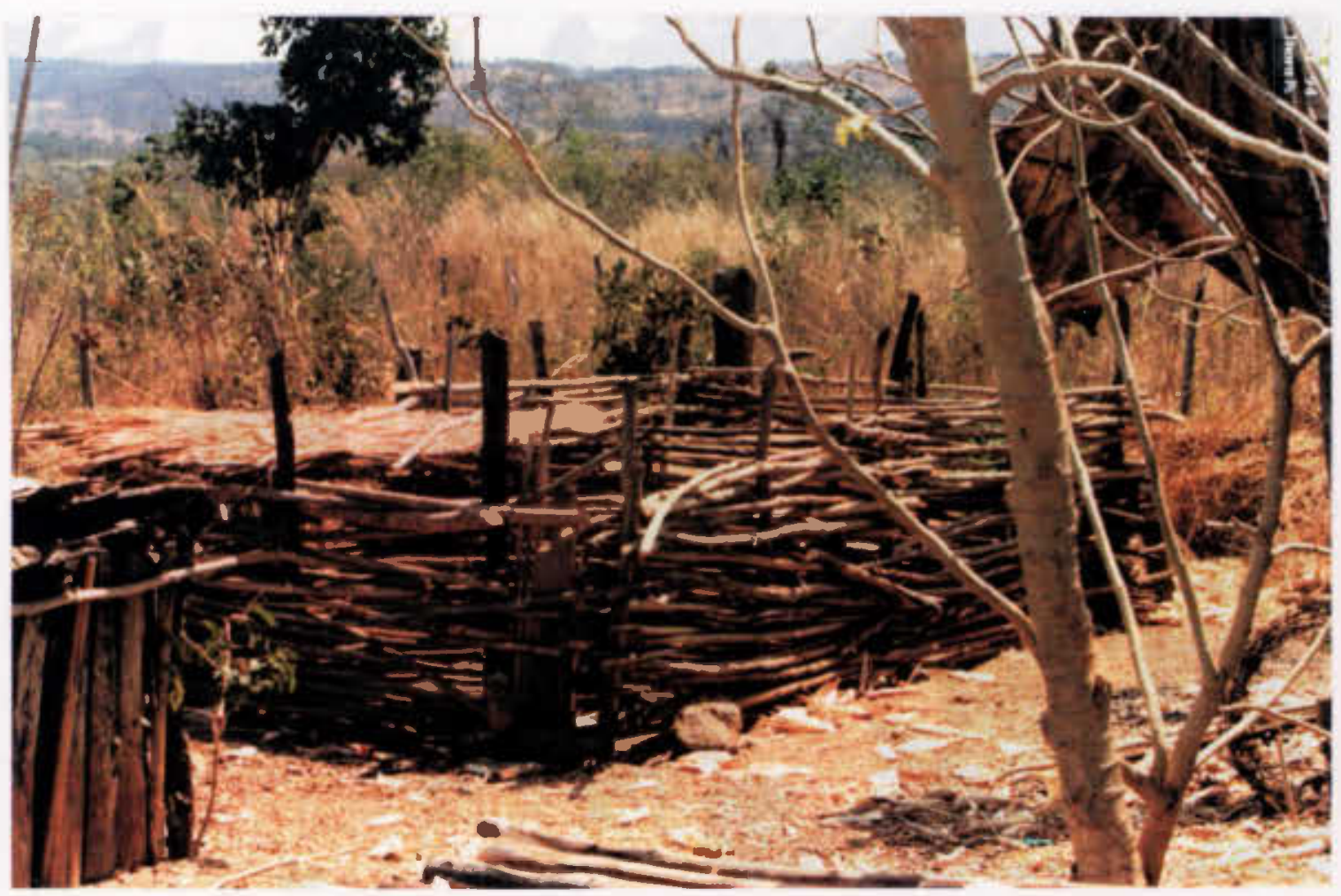

Figura 5.2-5.

Tipo de chiqueiro freqüente na região de estudo. 


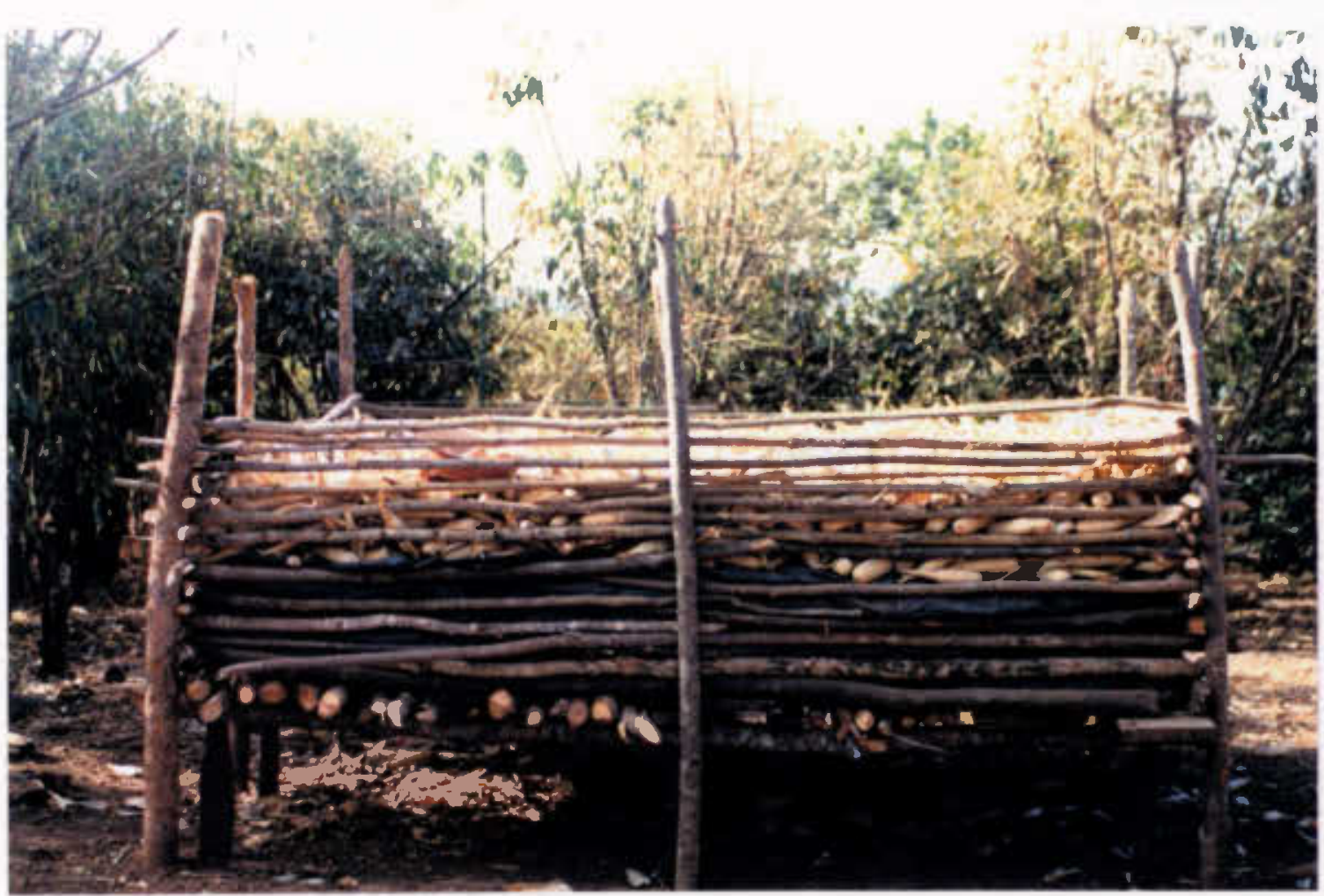

Figura 5.2-6.

Paiol aberto no peridomićlio.

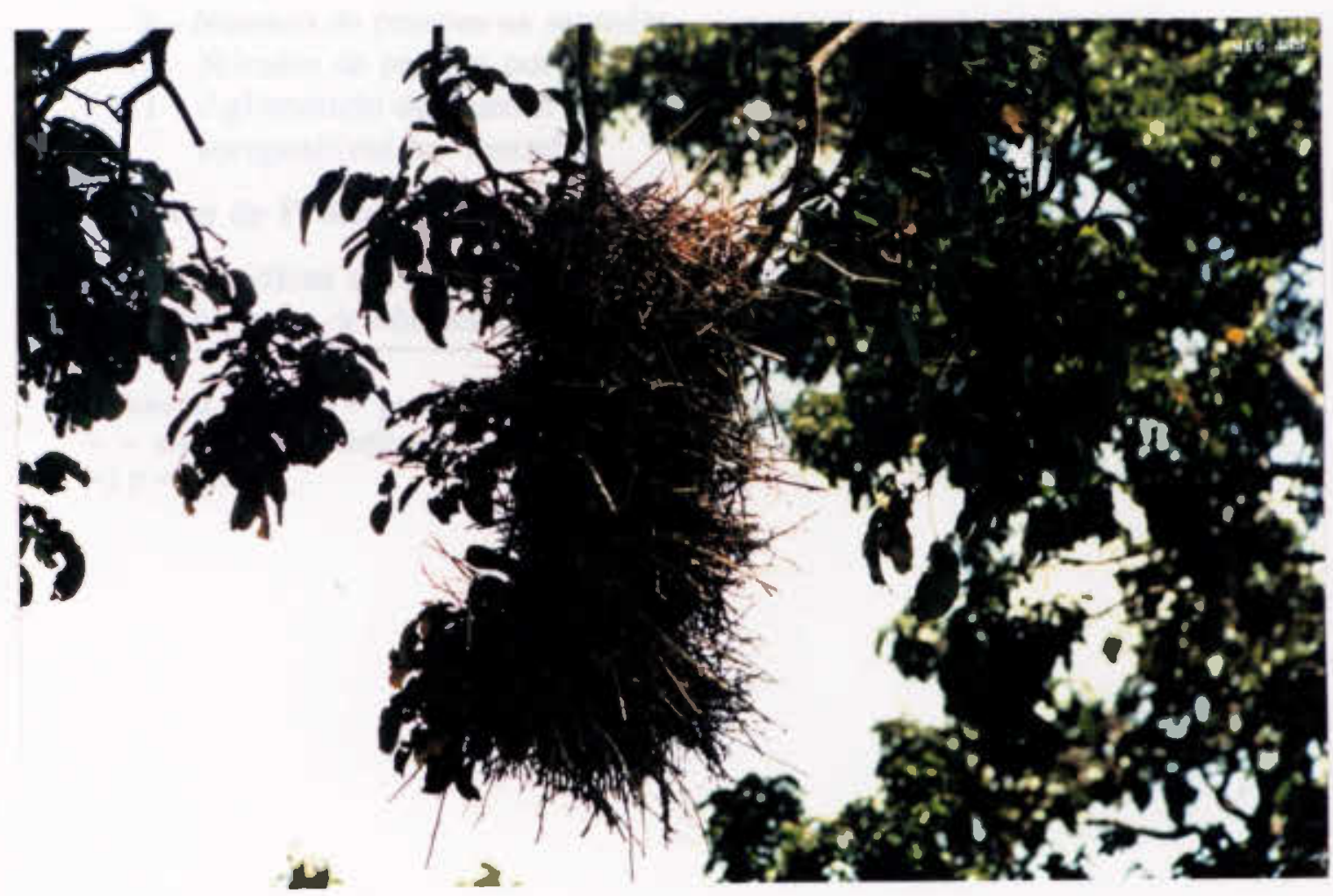

Figura 5.2-7.

Ninho de graveteiro no peridomicílio. 
Tabela 5.2-18.

Resumo da associação de variáveis investigadas para infecção pelo Trypanosoma cruzi em crianças de área rural.

\begin{tabular}{lll}
\hline Variáveis & $\begin{array}{l}\text { Banco de } \\
\text { dados 1 }\end{array}$ & $\begin{array}{l}\text { Banco de } \\
\text { dados 2 }\end{array}$ \\
\hline
\end{tabular}

\section{Fatores de Risco}

Presença de vetores

1 - Moradia infestada ${ }^{a}$

2 - Presença de exúvia na moradia

3 - Identificação de triatomíneo pelo morador

\section{Características familiares}

4 - Média de pessoas/família

5 - Soropositividade da mãe

6 - Soropositividade do pai

7 - Soropositividade de um dos pais

8 - Soropositividade de ambos os pais

9 - Número de pessoas na moradia

10 - Número de pessoas por cômodo

11 - Aglomerado de pessoas soropositivas na moradia

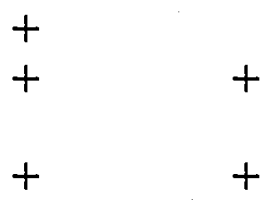

$+$

$+\quad+$

$(+)$

$+\quad+$

$+\quad+$

$+$

$+\quad+$

$+$

\section{Fatores de Proteção}

\section{Características do domicílio}

$$
1 \text { - Número de cômodos }
$$

- Moradia infestada = presença de triatomíneo ou vestígios (cório, exúvia, fezes)

$t_{t}=$ associação estatisticamente significante com criança soropositiva, odds ratio $>1.0$

$(+) \mathrm{p}=0,05$ 


\subsection{Considerações metodológicas}

\section{a. Delineamento do estudo}

Não obstante as vantagens relativas ao custo/benefício e facilidade operacional, poucos foram os estudos caso-controle conduzidos até o momento para infecção ou doença de Chagas. A metodologia caso-controle foi originalmente proposta para estudos de causalidade de doenças não infecciosas, especialmente doenças crônico-degenerativas (Breslow \& Day, 1980), nas quais o aparecimento de um caso novo independe do número de casos previamente existentes na população (eventos independentes). Em contraste, nas doenças infecciosas, a quantidade de indivíduos doentes na população é o que determina o aparecimento de novos casos, devido à propagação da infecção diretamente entre indivíduos, ou indiretamente através de vetores (eventos dependentes). Por este motivo, o postulado da independência de eventos pode não ser totalmente atendido para doenças infecciosas, especialmente quando a fonte de infecção encontra-se na moradia (Halloran \& Struchiner, 1991; Longini et al., 1988). Entretanto, considerando-se a evolução crônica da infecção pelo T. cruzi, com marcadores sorológicos duradouros, a metodologia caso-controle pode representar uma abordagem apropriada para avaliar múltiplos fatores de risco.

Algumas limitações quanto ao uso desse tipo de estudo devem ser mencionadas em relação à infeç̧ão pelo T. cruzi: a) os resultados de sorologia na definição de caso/controle representam um marcador de infecção no passado, significando casos prevalentes de infecção e não incidentes; b) mensuração de exposições ambientais e de comportamento não estão diretamente relacionadas à idade de aquisição da infeç̧ão, uma vez que se pode estar medindo fatores de risco possivelmente transitórios; c) a seleção de casos e controles da mesma comunidade implica em pareamento por condição sócio-econômica e muitas vezes por variáveis ambientais, o que pode dificultar a avaliação dessas variáveis na análise, devido à possibilidade de super-pareamento. Todos estes aspectos serão discutidos no 
decorrer deste Capitulo.

Nas últimas décadas, paralelamente ao grande volume de pesquisas utilizando a metodologia caso-controle, cresceu também o número de publicações enfocando a preocupação na prevenção e mensuração das diferentes fontes potenciais de vícios metodológicos nesse tipo de estudo (Sackett, 1979; Duffy et al., 1989; Kopec \& Esdaile, 1990; Duffy et al., 1992).

Valores de odds ratio obtidos em estudos caso-controle tendem a aproximar-se dos valores do risco relativo quando casos e controles selecionados da população de estudo são representativos da população alvo, particularmente quando a incidência do evento estudado é baixa. Por tratar-se de estudo caso-controle populacional, todas as crianças da área de estudo, de 7-12 anos, foram triadas sorologicamente para detecção das infectadas pelo T. cruzi (casos). A escolha da população de escolares foi oportuna para a região por tratar-se de área de baixa densidade populacional, com grande espaçamento entre as casas, o que dificulta a coleta de sangue nas moradias. Considerando-se que a infecção ocorre na primeira década de vida, estima-se que um contingente destas crianças infectadas possa representar casos prevalentes e não, necessariamente, casos incidentes de infecção.

Uma das maiores possibilidades de vícios de seleção em estudos casocontrole refere-se à escolha do grupo controle. Wacholder et al. (1992a), em excelente revisão de literatura, discutem os princípios envolvidos na seleção de controles, avaliando também diferentes tipos de controles e opções disponíveis no delineamento de estudos caso-controle (Wacholder et al., 1992a; Wacholder et al., 1992b; Wacholder et al., 1992c). O grupo controle ideal (Greenberg, 1983) raramente existe em estudos epidemiológicos, o que faz com que a obtenção de controles seja problemática, na maioria das vezes. Um dos motivos é o fato de que os princípios da comparabilidade na seleção de controles geralmente são influenciados pelo princípio da eficiência, ou seja, disponibilidade de recursos e tempo. Este estudo foi delineado levando em conta estrita aderência aos princípios 
da comparabilidade na seleção de casos e controles: a) Fonte de seleção - o grupo controle foi selecionado da mesma população que os casos. Este aspecto, aliado à baixa mobilidade populacional na área de estudo durante a última década, deve ter grandes níveis de comparabilidade entre casos e controles, quanto às variáveis de exposição estudadas, evitando vícios de seleção. Uma vantagem adicional deste tipo de controles é a possibilidade do uso dos resultados obtidos para exposições em controles (por exemplo, sorologia das mães de crianças soronegativas) como representativos da população em geral como discutido no item 6.2 ; b) variáveis de confusão - outro aspecto já mencionado e de importante valor metodológico diz respeito ao pareamento dos controles por variáveis reconhecidamente de confusão, sexo e idade, o que deve ter contribuido para minimizar distorções nas estimativas de odds ratios c) acurácia - não há motivos para acreditar em diferenças no grau de acurácia das informações obtidas quanto a exposições entre casos e controles, o que induziria a vícios de informação. A maior parte das exposições foi medida diretamente, registrando-se a presença ou ausência da característica pesquisada no ambiente doméstico e peridoméstico dos casos e controles. Outros argumentos favorecendo este aspecto encontram-se detalhados no item Erros de medida de exposição.

\section{b. Critérios para definição de casos e controles}

A estratégia da triagem sorológica para seleção de casos e controles foi planejada para que se obtivesse o maior número possível de casos, assegurando-se, no entanto, uma alta especificidade na definição dos controles. No estudo, três técnicas sorológicas foram utilizadas para definição de criança infectada (caso). O processamento das reações foi efetuado em laboratório de reconhecido mérito pela Organização Mundial de Saúde para diagnóstico sorológico da doença de Chagas (WHO, 1991b, Luquetti, 1990) com experiência em estudos populacionais, tanto em sangue venoso como em eluato (Zicker et al., 1989). O uso do papel de filtro para as técnicas de HAI e ELISA foi recentemente avaliado em estudo populacional conduzido em 6.222 trabalhadores urbanos da cidade de Goiânia 
(Zicker et al., 1990d). A coleta de sangue por punção digital e armazenamento em papel de filtro é recomendada como o melhor método para fins soroepidemiológicos, apesar de degradação precoce de IgM ter sido relatada (Guimarães et al., 1986). A investigação sorológica foi conduzida em duas fases; inicialmente as amostras foram testadas em eluatos de papel de filtro, pelas facilidades operacionais relativas à coleta de um grande volume de amostras. Nessa etapa os testes foram realizados em paralelo, empregando-se as técnicas referidas com pontos de corte abaixo dos habitualmente utilizados para diagnóstico de infecção pelo T. cruzi; este procedimento teve como objetivo aumentar a sensibilidade da deteç̧ão de casos (Gallen \& Gambino, 1975), considerando-se a baixa prevalência estimada para os municípios no estudo piloto, as baixas sensibilidades de cada técnica relatadas no estudo citado anteriormente (Zicker et al., 1990d) e as dificuldades operacionais relativas à coleta de sangue em meio rural. A segunda fase da investigação sorológica consistiu da retestagem das amostras positivas em pelo menos duas técnicas, utilizando-se da mesma forma os três testes; essa estratégia de triagem em série, aliada ao aumento do ponto de corte, apresentou como vantagem o aumento da especificidade na definição de casos (Galen \& Gambino, 1975), condição indispensável em estudos caso-controle (Hennekens \& Burings, 1987; Schlesselman, 1982). Assim, esse procedimento evitou que resultados positivos, porém com baixo limiar de reatividade devido a possíveis reações cruzadas, fossem interpretados como caso. Desta forma, a decisão final de caso e controle baseou-se na positividade em pelo menos 2 das técnicas e negatividade em todos os testes, respectivamente.

Durante toda a investigação sorológica, procedimentos foram adotados para minimizar tendenciosidades nos resultados sorológicos (viéses intralaboratório). As amostras colhidas em sangue venoso foram enviadas ao laboratório com numeração diferente da amostra correspondente, colhida em papel de filtro. A adoção dessa medida não só assegurou que os exames fossem realizados de forma cega, como também permitiu avaliar a confiabilidade (Fleiss, 1981) dos resultados fornecidos pelo laboratório. 
Embora a detecção do parasita pelo método do xenodiagnóstico pudesse fornecer informações mais exatas por se tratar de crianças, seu custo-beneficío seria alto levando-se em conta a operacionalização desse método no estudo. A sorologia é o procedimento mais inócuo, confiável e de fácil operacionalização para detecção de infecção pelo T. cruzi, especialmente em áreas rurais. A definição de infecção pelo T. cruzi baseou-se exclusivamente em resultados de testes sorológicos. Considerando-se a baixa idade das crianças e baixa letalidade da doença de Chagas, acredita-se que a prevalência de infecção medida pelo estudo se aproxime da incidência de infecção. Existe consenso de que a infecção pelo $\mathbf{T}$. cruzi é adquirida na primeira década de vida enquanto a morbidade ocorre a partir da segunda década (Dias, 1982) e tendo-se em vista a faixa etária de 7 a 12 anos dos participantes, seria de se esperar que ocorresse infecção pelo T. cruzi sem doença clínica ou alterações orgânicas. No entanto, esta delimitação entre infecção e doença na infância não está bem estabelecida em estudos populacionais.

Em pesquisa recente, utilizando-se também a metodologia caso-controle em 421 das 447 crianças participantes do estudo, verificou-se que 11 delas apresentavam alterações eletrocardiográficas específicas de cardiopatia chagásica. Bloqueio de ramo direito(BRD) foram registradas em 10 (7\%) de 141 crianças soropositivas (casos) e em $1(0,4 \%)$ de 280 controles. (Andrade et al., 1993b). A presença de BRD em crianças soropositivas assintomáticas indica que 0 envolvimento cardíaco na doença de Chagas é precoce o que pode ter repercussões nos índices de letalidade. Esse resultado sugere que a associação entre infecção pelo T. cruzi e fatores de riscos estudados estão sujeitos a diferentes graus de severidade no espectro da forma indeterminada da doença de Chagas.

Outra investigação realizada com essa mesma população de casos e controles mostrou resultados interessantes referentes à avaliação antropométrica. Desnutrição pregressa e baixo peso estiveram estatisticamente associados à infecção pelo T. cruzi mesmo após ajustamento por sexo e idade. Cento e sessenta e cinco dos 460 participantes do estudo eram irmãos, casos e/ou controles, e por este 
motivo compartilhavam hábitos alimentares/culturais. Esses achados sugerem que diferenças sociais entre casos e controles não poderiam explicar a associação infecção pelo T. cruzi-desnutrição embora o modelo caso-controle não indique a direção dessa associação (Andrade et al., 1993a).

Os resultados de ambas as pesquisas mencionadas acima confirmam que os determinantes da transição entre período de infecção e doença necessitam ser elucidados ou quantificados para a doença de Chagas e que o real prognóstico da soropositividade para anticorpos anti-T. cruzi ainda não está bem estabelecido.

\section{Tamanho da amostra}

A seleção de dois controles por caso foi uma estratégia para aumentar a precisão do estudo, tendo-se em vista que 150 casos e 300 controles correspondem a um poder estatístico de aproximadamente $90 \%$. Por outro lado, a escolha de um controle por caso representaria um decréscimo de $10 \%$ no poder estatístico do estudo. Um número maior de controles, até o máximo de 4 , poderia ter sido selecionado, considerando-se que toda a população alvo foi triada sorologicamente. Para valores acima de 4 controles seria obtido pouco aumento na precisão (Ury, 1975). Porém, a escolha de 3 ou 4 controles por caso não resultaria em aumentos razoáveis do poder estatístico que justificassem as dificuldades operacionais, devido ao acréscimo de no mínimo 50 e 120 entrevistas em residências rurais, respectivamente.

Uma boa maneira de se aumentar a precisão em estudos caso-controle é aumentar o número de casos, estendendo-se a busca de casos para outras regiões ou prolongando-se o tempo do estudo, ao invés de se aumentar o número de controles. Porém, em se tratando de área rural, este procedimento violaria o princípio da eficiência. Vale ressaltar que a estratégia de triagem sorológica de escolares de 7 a 12 anos na região permitiu detectar praticamente todas as crianças infectadas nessa faixa etária. 


\section{d. Erros de medida de exposição}

É reconhecido o fato de erros de classificação de exposição, quando não diferencial, resultarem em valores de odds ratios próximos da unidade. A mensuração das variáveis de exposição foi feita através de entrevista domiciliar, sendo que tanto o entrevistador quanto o participante desconheciam o resultado do teste sorológico, o que assegura a comparabilidade da medida de exposição entre casos e controles. A sensibilidade e especificidade das medidas das variáveis de exposição não foram comprometidas, uma vez que grande parte das vezes as medidas foram feitas de forma direta e objetiva, através da inspecção do ambiente doméstico e peridoméstico (Hulka \& Margolin, 1992). Vício de memória entre casos e controles, apontados como freqüentes em algumas situações, foram pouco prováveis, uma vez que ambos, casos e controles, eram assintomáticos. É esperado neste tipo de estudo que exista um grande contingente de casos-controles pertencentes a uma mesma família. Esta situação implica que mesmas exposições ambientais estariam presentes simultaneamente para casos e controles. Uma análise com exclusão de casos e controles que residiam na mesma casa foi realizada, o que deu origem ao banco de dados 2 . Essa estratégia de análise minimizou essa fonte de vício, permitindo controlar para exposições comuns entre membros da mesma família. Outra alternativa de análise seria através de análise de aglomerado, quando se dispõe de informações de todos os habitantes da moradia, o que não foi objetivo do estudo.

Devido à baixa taxa de migração dos habitantes da região, o tempo de residência da família na moradia atual foi, em $90 \%$ das vezes, igual ou maior que a idade da criança, o que possibilitou que todas as variáveis de exposição medidas no estudo pudessem ser realmente associadas ao participante, caso-ou controle. 


\section{e. Estratégia de análise}

Em estudos analíticos em doença de Chagas, a avaliação de variáveis de exposição relativas ao ambiente doméstico e peridoméstico e características do comportamento humano na transmissão do $\mathbf{T}$. cruzi têm se restringido à análise de poucas variáveis, raramente ajustando por fatores potenciais de confusão. Vale ressaltar que o uso do método de regressão logística em estudos sobre doença de Chagas é recente na literatura, tanto em estudos de prevalência como em casocontrole (Zicker, 1988; Zicker et al., 1989; 1990a; 1990c; Starr et al., 1991; Gürtler et al., 1991), como em estudos prospectivos (Mota et al., 1990; Maguire et al., 1987). A transmissão do T. cruzi para o homem em áreas rurais é resultante da coexistência de múltiplos fatores relacionados ao vetor, ao reservatório animal e ao homem. $\mathrm{O}$ presente estudo foi delineado para analisar simultaneamente vários fatores de risco potenciais envolvidos na cadeia de transmissão do T. cruzi, assegurando que exposições associadas à infecção em crianças pudessem ser controladas em modelo multivariado pelas variáveis de confusão.

Controles foram selecionados através de pareamento por sexo, idade e escola e optou-se por uma análise estastística também pareada. De acordo com Schlesselman (1982), uma quebra do pareamento poderia ser realizada na análise de dados nesse tipo de estudo. No entanto, pareceu interessante a preservação do pareamento na análise, uma vez que resultados obtidos na triagem das crianças para a seleção de participantes desse estudo mostrou que a infecção pelo T. cruzi em crianças estava estatisticamente associada a sexo e faixa etária (Andrade et al., 1992b). Essa estratégia de análise apresenta, teoricamente, a vantagem de evitar valores subestimados de odds ratios que ocorrem quando a análise de dados pareados é realizada de forma não pareada (Breslow \& Day, 1980; Schlesselman, 1982; Hennekens \& Burings, 1987). Entretanto, deve-se lembrar algumas restrições da análise pareada, especialmente em relação a detecção de interações, o que pode ser melhor visualizada em análise estratificada (Moncau, 1991). 
O efeito de erros de classificação devido a superpareamento em estudos caso-controle pareados tem sido extensamente estudado. Erros não diferenciais ou aleatórios, entre casos e controles, parecem ser função direta do excesso ou grande número de fatores pareados referentes a exposições entre casos e controles (Greenland, 1982). Como já mencionado, os municípios incluídos no estudo apresentavam populações com padrão sócio-econômico semelhante. Nestas circunstâncias, o pareamento de casos e controles por escolas no delineamento do estudo, aliado à forte determinação social na ocorrência da doença de Chagas, pode ter conduzido a um superpareamento de variáveis sócio-econômicas. Esse fato acarretou uma diminuição do número de triplos discordantes disponíveis para o cálculo do odds ratio para algumas variáveis do ambiente doméstico e/ou peridoméstico o que, conseqüentemente, levou a uma perda do poder estatístico do estudo, por diminuição do tamanho da amostra. Observa-se, por exemplo, que, para a variável moradia infestada por triatomíneo (Tabela 5.2-3), 120 triplos eram concordantes quanto à ausência de exposição e para a variável anexos (Tabela 5.216.) 121 triplos eram concordantes para a presença de exposição. Em ambas as situações, menos de 30 triplos foram utilizados para os cálculos de estimativas de riscos.

Especificamente em relação à doença de Chagas, a detecção de fatores de risco sócio-econômicos associados à infecção e/ou doença possivelmente seria mais evidente comparando-se diferentes comunidades. Halloran \& Struchiner (1991), ao abordar aspectos metodológicos referentes a eventos dependentes, sugerem que se selecione comunidades localizadas em áreas geográficas não contíguas para possibilitar a intervenção em fatores de risco. No entanto, a seleção de comunidades como unidade de estudo em pesquisas analíticas, em doença de Chagas, tem sido rara e pela dispersão da população rural das áreas estudadas esta abordagem seria pouco eficiente.

A apresentação dos resultados mostrando os triplos pareados, embora pareça de difícil compreensão, possibilitou a visualização de todas as variações de 
exposições entre casos e controles, considerando os triplos concordantes e os triplos parcialmente e totalmente discordantes. Esse procedimento permite uma maior proximidade entre o pesquisador e os dados analisados. Representa, também, uma alternativa para conferir os cálculos das medidas de associação obtidas por processamento eletrônico.

A análise dos potenciais fatores de risco para infecção na criança considerou também a soropositividade da mãe como uma medida de aproximação (Evans et al.,1992) para avaliar a possível transmissão congênita em nossa área. Um percentual dos casos selecionados nesse estudo poderia ter sido infectado por via transplacentária. Esta preocupação deveu-se às altas taxas de soropositividade $(23,0 \%)$ obtidas no Inquérito Nacional para Doença de Chagas, realizado de 1975 a 1980 (Camargo et al., 1984) em crianças de 7-14 anos destes mesmos municípios rurais. Esta coorte de crianças infectadas na década de 70 , do sexo feminino, poderia se constituir hoje em mães das crianças participantes do estudo, indicando a real possibilidade de transmissão congênita da infecção. Neste sentido, a análise levou em conta a comparação dos resultados da sorologia das mães de casos e controles. 


\subsection{Fatores associados à transmissão}

Neste estudo alguns achados epidemiológicos relativos à infecção pelo T. cruzi na infância foram obtidos. Uma associação significativa entre criança soropositiva e evidência de triatomíneo - presença do vetor ou vestígios - no domicílio foi detectada. Considerando que a doença de Chagas em áreas rurais é uma antropozoonose transmitida por vetor, a presença ou evidência de vetores na moradia como fator de risco para infecção em crianças parece, inicialmente, um achado óbvio. Entretanto a captura de vetores por inspecção manual não esteve associada com criança infectada. Antunes (1985) ressalta que o T. cruzi é um fator necessário para infecção apesar de não suficiente para manifestação clínica da doença de Chagas. A relação entre existência de vetor, causa necessária (Kleinbaun, 1982), e criança infectada, somente foi verificada quando se incluiu a presença de exúvia, cório ou fezes, obtendo-se assim, uma variável que indicava a presença de vetor em momentos anteriores àquele da investigação.

Este estudo optou por ampliar a detecção de triatomíneos incluindo a presença de vestígios dos vetores da doença de Chagas, como forma de indicar a infestação atual ou pregressa do domicílio. Esta estratégia foi bem sucedida, uma vez que a associação entre a presença de vestígios e criança soropositiva pôde ser detectada no estudo. Estudos publicados recentemente mostraram claramente que a presença de vetores pode ser subestimada quando a busca baseia-se exclusivamente na captura manual, particularmente em áreas que se encontram na fase de vigilância do programa de controle de vetores. Wisnivesky-Colli et al. (1987) compararam os métodos da Maria box e Gómez-Núñez para detecção passiva de triatomíneo em domicílios, ambos utilizando como monitores cartolinas em formato de caixas pequenas colocadas nas paredes das moradias. Os resultados mostraram que a presença de qualquer evidência de triatomíneo - adulto, ninfa, exúvia, cório ou fezes - quando comparada à presença exclusiva do vetor, determinava uma maior detecção de triatomíneo em ambos os métodos, após 30 dias de observação. Marsden et al. (1982), em estudos conduzidos em Mambaí no 
período de 1975 a 1979, em área contígua ao presente estudo, já chamavam a atenção para o fato de que a borrifação das casas, por conduzir a uma baixa densidade populacional de vetores, fazia com que se encontrasse uma maior freqüência de evidências de triatomíneos em relação ao encontro de adultos ou ninfas, além do fato das fezes, cório e cascas permanecerem por muito tempo em paredes que são limpas raramente.

Nas últimas duas décadas, estudos realizados em áreas rurais do município de Castro Alves, Bahia, encontraram uma associação entre sororeatividade de crianças e tipo de construção da casa e densidade de vetores (Mott et al., 1978; Piesman et al., 1985a; Piesman et al., 1985b). No entanto, existem alguns aspectos epidemiológicos que devem ser ressaltados, quando se comparam os municípios da Bahia, na década de 70 e 80 com os da região de estudo na década de 90 . Um deles diz respeito às altas taxas de infestação de $18 \%$ a $25 \%$ detectadas por Piesman et al. (1985b) durante o período de 1974-1982, significando uma área de alta densidade de triatomíneos, com predominância de $\mathbf{P}$. megistus naquela região. Além do mais, esses triatomíneos apresentavam taxas elevadas de infecção pelo T. cruzi, havendo uma relação entre altas taxas de $\mathbf{P}$. megistus infectados e casas com crianças soropositivas (Piesman et al., 1985a). Em contraste, no presente estudo, os vetores predominantes foram $\mathbf{T}$. infestans e $\mathbf{T}$. sordida, encontrados respectivamente em apenas $5,2 \%$ e $2,0 \%$ de 267 moradias visitadas (banco dados 2), sendo que em somente duas casas foram encontrados triatomíneos infectados. Essas baixas taxas de infestação podem ser explicadas como sendo resultado da borrifação das moradias com inseticida pelo programa de controle da doença de Chagas. Ainda, de acordo com Mott et al. (1978), mais de 50\% $(n=110)$ das casas investigadas de Castro Alves investigadas eram de pau-a-pique e 2/3 das crianças soropositivas residiam em casas com esse tipo de parede. Esses resultados diferem sobremaneira do presente, onde vários materiais de construção eram utilizados e apenas $4 \%(n=11)$ das casas dos casos e controles eram construídas com pau-a-pique nas paredes. 
Vários tipos de materiais de construção utilizados nas paredes, teto e piso têm sido associados estatisticamente à presença de diferentes espécies de triatomíneos no interior da habitação. Estudos realizados na Costa Rica, também mostraram uma associação significativa entre teto de telha e presença de $\mathbf{T}$. dimidiata quando comparado a teto de telha galvanizada. Porém os autores admitem a possibilidade desse achado estar condicionado à freqüente presença de depósitos de telhas adjacentes às moradias, local de abrigo de triatomíneos (Starr et al., 1991). A presença de chão sujo também foi descrita como associada à presença desse vetor, quando comparada a outros tipos de piso, assim como a presença de montes de lenha no peridomicílio (Zeledón \& Vargas, 1984; Starr et al., 1991). A homogeneidade do padrão de construção das casas de casos e controles no estudo pode ter contribuído para a não detecção de riscos significativos entre tipo de material de construção empregado na moradia de criança soropositiva.

Uma associação estatisticamente significante entre número de pessoas, na família e por cômodo e risco de infecção em crianças foi detectada neste estudo. Este fato poderia ser explicado em analogia à relação direta descrita entre tamanho da família e densidade de barbeiros (Schofield, 1980). Marsden et al. (1982) lembram que em famílias numerosas a higiene é mais precária, sendo que o hábito comum de armazenar pertences embaixo das camas, frestas de janelas e portas, favorece a colonização de barbeiros.

Embora a metodologia utilizada não permitisse uma avaliação de aglomerado familiar de soropositividade, a análise dos resultados da sorologia dos pais e de todas as crianças de 7 a 12 anos de cada família mostrou uma maior proporção de pessoas soropositivas nas casas dos casos quando comparada às casas do grupo controle. Estes resultados indicam a possibilidade de agregação familiar de soropositividade, mostrada anteriormente por outros autores (Marsden et al., 1969; Mott et al., 1976). Mott et al. (1976), em estudo populacional, verificaram que quanto menor a idade da criança infectada, maior a taxa de soropositividade nos demais membros da família. As variações encontradas nas taxas de soropositividade 
em crianças sugeriram uma agregação familiar de infecção, mesmo após ajuste por tamanho da família e idade dos moradores. Em outro estudo caso-controle para avaliar fatores de risco para cardiopatia chagásica, Zicker et al., (1990c) verificaram que indivíduos soropositivos com história de doença cardiovascular em irmãos apresentaram mais alterações eletrocardiográficas quando comparados aos indivíduos soropositivos cujos irmãos não referiam doença cardiovascular. Segundo os autores, levando-se em conta os diferentes locais de procedência rural de casos e controles, esses achados sugerem uma aglomerado geográfico de casos de cardiopatia chagásica, embora o delineamento do estudo não permita conclusões mais acuradas.

Dos animais presentes nas habitações, nenhum esteve associado à infecção na criança. Estudos realizados na Argentina têm mostrado o importante papel dos cães como reservatório do T. cruzi. Cães soropositivos apresentaram uma maior capacidade de infectar triatomíneos quando comparados a crianças e adultos soropositivos (Gürtler et al., 1986). Em casas com e sem crianças soropositivas, a percentagem de $\mathbf{T}$. infestans foi mais de 4 vezes maior quando cães soropositivos estavam presentes (Gürtler et al., 1991). Os resultados presentes mostraram uma baixa prevalência de animais no domicílio, tanto na moradia de casos como na de controles. Mesmo a estratégia de se testar a presença de pelo menos um animal na moradia não resultou em riscos significativos associados à infecção na infância.

Achado intrigante no estudo foi a associação entre ninho de graveteiro e criança infectada, com valor de odds ratio no limite da significância estatística. Estudos do ciclo silvestre do $\mathbf{T}$. cruzi realizados no município de Formosa, vizinho à área de estudo, mostraram que o ninho de graveteiro só foi encontrado infestado por Psammolestes tertius e num percentual de 51,9\%. Naquele estudo, P. tertius foi a espécie dominante no ambiente silvestre daquele município (Mello, 1981). Até o momento, esta espécie tem sido descrita principalmente em ninhos de graveteiro e eventualmente de outras aves, não havendo registro de sua presença no interior de domicílios. Entretanto, em estudos realizados em laboratório, o P. tertius 
funcionou como meio replicador do T. cruzi, após ter sido alimentado em camundongo infectado. A criação e a infecção do P. tertius experimentalmente, mostram o potencial deste triatomíneo de se adaptar às condições criadas pelo homem e de se infectar, replicar e transmitir o T. cruzi (Silva \& Lustosa, 1993). Esses achados adquirem importância epidemiológica, pois mostram a possibilidade desse triatomíneo participar como vetor do ciclo silvestre da tripanosomíase americana. A associação entre ninho de graveteiro e criança soropositiva pode estar indicando outro fator de risco não incluído na investigação. Outras variáveis devem ser pesquisadas, como por exemplo, ninhos de roedores ou gambás nos troncos de árvores onde são encontrados ninhos de graveteiros e tipo de palmeiras mais associadas à presença de ninho de graveteiro.

Recentemente, alguns autores têm utilizado os indicadores de validade, sensibilidade, especificidade e valores preditivos na avaliação de fatores prognósticos em estudos tipo caso-controle (Victora et al., 1990). Considerando-se que para o cálculo da sensibilidade há necessidade de se comparar determinado procedimento ou teste com um padrão certeza, a metodologia caso-controle parece apropriada por fornecer definição altamente específica de evento positivo (caso), quer seja doença/infecção. Neste sentido, em nosso estudo os casos foram selecionados por triagem sorológica, utilizando altos pontos de corte para definição de soropositividade assegurando desta forma uma alta especificidade na definição de caso. Além deste fato, por tratar-se de estudo populacional onde os casos representaram $94,3 \%(149 / 158)$ de todas as crianças soropositivas da região os vícios de seleção foram minimizados. Assim, pareceu tecnicamente viável calcular a sensibilidade de algumas variáveis de exposição utilizando um banco de dados adicional que apesar da redução do tamanho da amostra, tornou possível este cálculo por considerar apenas um participante por família. Utilizando-se a informação fornecida pelo proprietário sobre a presença de triatomíneo na moradia nos últimos 5 anos foi possível obter-se um índice de sensibilidade de $98 \%$ na detecção de moradia de criança soropositiva. Resultados semelhantes foram encontrados em pesquisa conduzida na mesma área, onde eficiente identificação de vetores pelos 
moradores (Sensibilidade $=90 \%$ ) foi constatada (Andrade et al., 1993c). Esses resultados indicam a factibilidade de programas horizontais através da participação comunitária no controle da doença de Chagas, além de ser um método simples e econômico para detecção de casa de criança infectada e/ou casa infestada. De fato, pesquisas realizadas no Estado de São Paulo mostraram que a captura de triatomíneos foi 6 vezes maior nas casas onde os moradores haviam notificado a presença de triatomíneos, quando comparada a captura realizada de rotina pela Superintendência de Controle de Endemias. Este fato mostra que a notificação de triatomíneos pela população é forma eficiente de se efetuar a vigilância no intradomicílio (Wanderley, 1991). Há necessidade de implementação do sistema de vigilância do Triatoma infestans nas áreas estudadas. Devido a alta eficiência da detecção de triatomíneos vetores da doença de Chagas por parte dos moradores e, levando-se em conta a baixa densidade de vetores nos domicílios observadas no estudo, o envolvimento da comunidade no processo de vigilância entomológica deve ser incentivado.

Encontrou-se baixa sensibilidade (5\%) da captura manual de barbeiros no domicílio na deteç̧ão de moradia de casos. Devemos lembrar, no entanto, que a coorte de crianças estudadas representa uma amostra da população nascida há pelo menos 7 anos, durante o período de 1979 a 1984, antes da fase de ataque do programa de combate ao vetor. Desta forma, tem-se uma relação tempo-dependente entre crianças soropositivas detectadas hoje e infestação de casas em anos anteriores, uma vez que a sorologia reflete o resultado de exposições que podem ter ocorrido no passado, podendo ser tanto por contato com vetores como por transmissão materna.

Em relação à especificidade, seu cálculo não foi possível pois diferentemente da sensibilidade, o total de controles não correspondeu a todas as crianças soronegativas pois os controles foram selecionados pareados por sexo e idade correspondendo ao dobro do número de casos. Este procedimento implicaria na não disponibilidade de um padrão-negativo representativo de todas as crianças 
soronegativas levando a um vício de seleção de não caso no cálculo da especificidade.

A forte associação entre mãe soropositiva e filho soropositivo foi observada em ambos os tipos de análises, pareada e não pareada, não se detectando associação estatística entre criança soropositiva e pai soropositivo. $\mathrm{Na}$ infecção pelo T.cruzi um percentual de óbitos ocorre na fase de infecção aguda, e portanto, fatores de risco avaliados para casos selecionados na fase crônica da infecção (casos prevalentes) estariam associados a sobreviventes da fase aguda (Zicker et al., 1990c). Assim, neste estudo, a associação entre mãe infectada e criança infectada ainda poderia estar subestimada. Assumindo que a associação entre sorologia do pai e sorologia do filho possa ser interpretada como transmissão por vetores, a diferença de risco entre mãe $(\mathrm{OR}=3,6)$ e pai $(\mathrm{OR}=1,6)$ indicaria o risco relacionado à mães soropositivas e filhos soropositivos. Duas hipóteses poderiam explicar esses resultados: a) a transmissão transplacentária do T. cruzi parece ser mais freqüente do que se supunha, como enfatizado em recente documento da Organização Mundial de Saúde (WHO, 1991c); b) a soropositividade de mães pode exercer certo efeito prejudicial em seus recém-nascidos não infectados congenitamente, à semelhança do descrito em estudos realizados em animais (Carlier et al., 1992).

A relação entre mãe soropositiva e filho soropositivo não é fato novo na literatura. Mott et al. (1976), ao observarem que crianças soropoșitivas de mães infectadas apresentavam idade inferior quando comparadas com as soropositivas de pais infectados, chamaram atenção para a possibilidade de uma resposta imunológica diferente em crianças de mães infectadas. Em modelos experimentais, tem sido mostrada uma diminuição na resistência à infecção pelo T. cruzi em camundongos nascidos de mães soropositivas. Carlier et al. (1992) compararam o curso da infecção pelo T. cruzi em dois grupos de camundongos sem infecção congênita, sendo um deles nascido de mães cronicamente infectadas e outro de mães não infectadas (controles). Taxas de mortalidade significantemente maiores foram 
observadas no grupo de camundongos de mães infectadas quando comparados à prole de mães não infectadas, após inóculo intraperitoneal de T. cruzi. Este foi o primeiro estudo a mostrar, experimentalmente, a marcada influência da sorologia positiva de mães, levando a um prejuízo na resposta imune da respectiva prole, fato este que foi considerado específico para o T. cruzi, uma vez que o curso da infecção com outros parasitas inoculados foi semelhante em ambos os grupos de camundongos.

Na transmissão congênita do T. cruzi tem sido mostrada a importância do mecanismo de imunofagocitose da placenta e a patogenicidade de diferentes cepas (Delgado \& Santos-Buch, 1978; Andrade 1982). Apesar do grande número de pesquisas dedicadas a este tema, ainda hoje não existe um consenso quanto ao efeito do status sorológico materno na resposta imunológica de filhos de mães cronicamente infectadas, bem como a duração da infecciosidade e eficiência da transmissão materna.

Embora casos e controles tivessem sido pareados por sexo e idade, houve o interesse em investigar a possibilidade da soropositividade materna estar diferentemente associada com o sexo e idade de crianças infectadas. Assim, a análise estratificada por estas duas variáveis conduziu a interessantes observações: crianças do sexo feminino e de 10-12 anos apresentaram maiores odds ratios quando comparadas às crianças do sexo masculino e de 7-9 anos. Não se tem motivos para crer que os maiores riscos do sexo feminino associados à soropositividade materna estejam na dependência de maiores níveis de exposição aos vetores, quando comparados ao sexo masculino, pois se estaria negando o critério de igual exposição à infecção. Entretanto, resultados semelhantes foram encontrados por outros autores, que também observaram uma maior freqüência de transmissão congênita no sexo feminino (Azogue \& Urioste, 1985; Azogue \& Darras, 1991). Na Bolívia, resultados apresentados por Azogue \& Darras (1991), em estudo recente de 78 recém-nascidos prematuros infectados pelo T. cruzi, permitem estimar um risco relativo de 1,7 associado à transmissão congênita no sexo feminino quando 
comparado ao sexo masculino. No entanto, vale ressaltar a possibilidade de diferenças na letalidade em relação ao sexo, como observado em estudos experimentais (Carlier et al., 1992).

Quanto à faixa etária, a diferença de idade levando crianças de 10-12 anos a apresentarem um maior odds ratio com soropositividade da mãe, poderia ser devido a um efeito coorte. De fato, a fase de ataque do programa de combate a vetores com utilização de inseticida nas moradias ocorreu em 1983; provavelmete conduziu a um decréscimo da infestação das casas por triatomíneos e, conseqüentemente, a menores taxas de infecção pelo T. cruzi na coorte de crianças de 7-9 anos, nascidas após este período.

Alguns autores têm enfatizado que em estudos tipo caso-controle raramente é possível detectar interação entre variáveis em níveis significativos devido ao tamanho da amostra (Smith \& Day, 1984; Pearce, 1989). Entretanto, uma interação estatisticamente significante foi obtida entre sorologia de pai e sorologia de mãe. Por este motivo essas variáveis não foram ajustadas entre si no modelo multivariado, uma vez que o efeito da soropositividade de mães em filhos soropositivos (casos) parece ser maior que o efeito da soropositividade de pais. Estes achados sugerem a possibilidade de transmissão congênita ou uma influência deletéria da soropositividade materna em seus descendentes.

Embora vários autores mencionem que casos incidentes de infecção/doença de Chagas representem transmissão por vetores, a possibilidade da via de transmissão congênita em áreas onde a população feminina apresenta altas taxas de prevalência de infecção pelo T. cruzi deve ser lembrada. Na área de estudo, 56\% das mulheres estavam infectadas e assumindo-se uma população de 7.500 mulheres em idade reprodutiva residentes na região e uma taxa de fertilidade de $10 \%$ (Fundação IBGE, 1987/1988), poder-se-ia estimar pelo menos 400 gestantes soropositivas por ano. Desta forma, a probabilidade de crianças nascerem de mães infectadas é alta, o que faz com que a possibilidade de persistência de infecção 
nestas comunidades devido a transmissão congênita mereça ser considerada. Estes achados têm implicações importantes do ponto de vista de saúde pública para os municípios estudados, onde o programa de controle da doença de Chagas tem focalizado principalmente a vigilância de focos residuais de triatomíneos. Além da relação vetor-homem, do ponto de vista epidemiológico a associação mãe soropositiva-filho soropositivo parece ser importante no mecanismo de transmissão via placenta e/ou na resposta imune na transmissão do T. cruzi nos municípios de Posse, Simolândia e Guarani de Goiás.

Recentemente, em Goiânia, detectaram-se resultados falso negativos fornecidos pela triagem sorológica para infecção pelo $\mathbf{T}$. cruzi realizada pelos bancos de sangue, o que mostra que, mesmo em área urbana, onde os testes são realizados em paralelo incluindo pelo menos duas técnicas, a prevenção da transmissão transfusional ainda não foi equacionada (Andrade et al., 1992a). Neste aspecto, é preocupante o achado de que quase $60 \%$ da população masculina adulta da região seja soropositiva para anticorpos anti-T. cruzi, o que aumenta o risco de transmissão pela transfusão de sangue e hemoderivados, especialmente em zona rural, onde a cobertura da triagem sorológica ainda é baixa e boa parte das transfusões ainda baseia-se na anamnese (Martelli et al., 1992). Aliado a esses fatos, procedimentos reconhecidamente eficazes, como adição de violeta genciana no sangue, também não têm sido utilizados, o que contribui para a questionável qualidade do sangue transfundido. Apesar do potencial de transmissão da infecção via sangue e hemoderivados, apenas um caso e um controle referiram receber transfusão de sangue no passado.

Considerando o padrão epidemiológico descrito neste estudo, em que mais da metade da população adulta feminina está infectada pelo Trypanossoma cruzi, a triagem sorológica de gestantes durante o pré-natal deve ser incorporada como atividade de rotina no programa de controle da doença de Chagas. Crianças nascidas de mães soropositivas devem ser investigadas para detecção de infecção congênita e tratadas. Apesar da disponibilidade de técnicas sensíveis para o 
diagnóstico da infecção congênita, através da detecção de antígenos de parasita em recém-nascidos (Freilij et al., 1983), do ponto de vista de saúde pública a indicação de tais técnicas deve levar em conta as dificuldades de ordem técnica e operacionais, comuns no meio rural. Mesmo assim, o diagnóstico da infecção congênita pelo achado do parasita seria eticamente aconselhável uma vez que se dispõe de drogas comprovadamente eficazes para o tratamento da doença de Chagas na fase aguda (Zaidenberg \& Segovia, 1993).

Por tratar-se de regiões ainda endêmicas, onde a transmissão ainda ocorre, os municípios estudados apresentam-se como locais privilegiados para condução de estudos prospectivos através do acompanhamento de coortes de recém-nascidos não infectados, de mães soronegativas e soropositivas, respectivamente, com o objetivo de testar o possível efeito prejudicial de soropositividade materna na transmissão não congênita da infecção pelo T. cruzi. 
7. CONCLUSÕES 


\section{CONCLUSÕES}

1. Este estudo detectou uma associação significativa entre criança soropositiva $e$ evidência de triatomíneo - presença do vetor ou vestígios - no domicílio. Crianças residindo em moradias infestadas (vetor ou vestígios) apresentaram odds ratio de 2,4 quando comparadas às que residiam em moradias não infestadas. A inclusão da presença de vestígios para definição de moradia infestada aumentou a detecção de associação com criança soropositiva.

2. O número de pessoas residentes na moradia atual, assim como o número de pessoas por cômodo, estiveram estatisticamente associados à infecção em crianças.

3. Uma maior proporção de pessoas soropositivas foi detectada nas casas dos casos quando comparada às casas do grupo controle. Estes resultados indicam a possibilidade de agregação familiar de soropositividade.

4. Utilizando-se a informação fornecida pelo proprietário sobre presença de triatomíneo na moradia nos últimos 5 anos, foi possível detectar-se $98 \%$ das moradias de crianças soropositivas. A utilização da comunidade como unidade de vigilância no programa de controle da doença de Chagas ficou evidente, uma vez que a presença de criança soropositiva esteve associada à identificação do vetor pelo morador. Estes resultados adquirem importância do ponto de vista de saúde pública pois indicam a exeqüibilidade de programas horizontais com participação comunitária levando a um aumento da sensibilidade da detecção de vetores, especialmente em áreas onde a população de triatomíneos é baixa.

5. Uma associação foi encontrada entre mãe infectada e filho soropositivo, não detectando-se associação entre criança soropositiva e pai soropositivo. Duas hipóteses poderiam explicar estes resultados: a) transmissão transplacentária do T. cruzi; b) efeito prejudicial exercido pela soropositividade materna em seus recémnascidos não infectados congenitamente. 
6. Estimou-se pelo menos 400 gestantes soropositivas/ano na área, o que implica que a probabilidade de crianças nascerem de mães infectadas é alta. Conseqüentemente, a possibilidade de persistência de infecção nessas comunidades devido a transmissão congênita deve ser considerada. Estes achados adquirem importância do ponto de vista de saúde pública para os municípios estudados onde o programa de controle da doença de Chagas tem focalizado exclusivamente a vigilância de focos residuais de triatomíneos.

7. Por tratar-se de caso-controle com seleção de participantes de triagem populacional, o estudo permitiu que se avaliasse a prevalência de anticorpos anti-T. cruzi em crianças, possibilitando estimar a magnitude da infeç̧ão nesta população. As implicações das altas taxas de soroprevalência $(8,0 \%)$ detectadas em crianças nos municípios estudados, adquirem importância do ponto de vista de saúde pública, expondo os infectados ao risco de desenvolvimento precoce de alterações cardíacas e/ou digestivas. 
8. REFERÊNCIAS BIBLIOGRÁFICAS 
ACQUATELLA, H.; CATALIOTI, F.; GOMEZ-MANCEBO, J.R.; DAVALOS, V.; VILLALOBOS, L. Long-term control of Chagas' disease in Venezuela: effects on serologic findings, electrocardiographic abnormalities, and clinical outcome. Circulation,76:556-62, 1987.

ALMEIDA, J.O. \& FIFE JR, E.H. Métodos de fijación del complemento estandarizado cuantitativamente para la evaluación crítica de antígenos preparados con Trypanosoma cruzi. Org. Panamer. Salud., Washington, 1976. Publ. Cient., N ${ }^{\circ} 319$.

AMATO NETO, V. Modalidades alternativas de transmissão: Empecilhos às cogitações de erradicação da doença de Chagas. Rev. Hosp. Clín. Fac. Med. São Paulo,39:93-5, 1984.

AMATO NETO, V. Doença de Chagas pós-transfusional. Rev. Hosp. Clín. Fac. Med. São Paulo,43:135-7, 1988.

AMATO NETO, V. \& MELLONE, O. Estudos sobre a eficácia da violeta de genciana na profilaxia da transmissão da doença de Chagas em bancos de sa. Investigação em voluntário, receptor de sangue de caso agudo, ao qual foi adicionado o corante. O Hospital,55:343-6, 1959.

ANDRADE, A.L.S.S.; MARTELLI, C.M.T.; PINHEIRO, E.D.; SANTANA, C.L.; BORGES, F.P.; ZICKER, F. Rastreamento sorológico para doenças infecciosas em bancos de sangue como indicador de morbidade populacional. Rev. Saúde Pública,23:20-5, 1989.

ANDRADE, A.L.S.S.; MARTELLI, C.M.T.; LUQUETTI, A.O.; OLIVEIRA, O.S.; SILVA, S.A.; ZICKER, F. Serologic screening for Trypanosoma cruzi among blood donors in central Brazil. Bull. Pan. Am. Health Organ.,26:157-64, 1992a.

ANDRADE, A.L.S.S.; ZICKER, F.; LUQUETTI, A.O.; OLIVEIRA, R.M.; SILVA, S.A.; SOUZA, J.M.P.; MARTELLI, C.M.T. Surveillance of Trypanosoma cruzi transmission by serological screening of schoolchildren. Bull. World Health Organ., 70:625-9, 1992 b.

ANDRADE, A.L.S.S. \& ZICKER, F. Chronic malnutrition and Trypanosoma cruzi infection in children. J. Trop. Pediatr., 1994 [no prelo].

ANDRADE, A.L.S.S.; ZICKER, F.; OLIVEIRA, R.M.; SILVA, S.A.; RASSI, A.G.; MARTELLI, C.M.T. Alterações eletrocardiográficas em crianças com infecção pelo Trypanosoma cruzi em área endêmica para doença de Chagas. [Apresentado ao $29^{\circ}$ Congresso da Sociedade Brasileira de Medicina Tropical, Fortaleza, 1993b]. 
ANDRADE, A.L.S.S.; ZICKER, F.; OLIVEIRA, R.M.; SILVA, S.A.; SILVA, I.G.; MARTELLI, C.M.T. Fatores de risco para infestação de casas pelo Triatoma infestans em Goiás. [Apresentado ao $29^{\circ}$ Congresso da Sociedade Brasileira de Medicina Tropical, Fortaleza, 1993c]

ANDRADE, S.G. The influence of the strain of Trypanosoma cruzi in placental infections in mice. Trans. R. Soc. Trop. Med. Hyg., 76:123-8, 1982.

ANDRADE, S.G.; BITTENCOURT, A.L.; FIGUEIRA, R.M.; CARVALHO, M.L. Estudo experimental de amostras do Trypanosoma cruzi isoladas de gestantes chagásicas. Rev. Pat. Trop.,2:301-10, 1973.

ANTHONY, R.L.; JOHNSON, C.M.; SOUSA, O.E. Use of MICRO-ELISA for quantitating antibody to Trypanosoma cruzi and Trypanosoma rangeli. Am. J. Trop. Med. Hyg.,28:969-73, 1979.

ANTUNES, C.M.F. Association between strains of Trypanosoma cruzi and clinical studies: A review. Rev. Soc. Bras. Med. Trop.,18(Supl.):17-21, 1985.

AZOGUE, E. \& DARRAS, C. Estudio prospectivo de la enfermedad de Chagas en recien nacidos con infección placentaria por Trypanosoma cruzi (Santa Cruz-Bolivia). Rev. Soc. Bras. Med. Trop.,24:105-9, 1991.

AZOGUE, E.; LA FUENTE, C.; DARRAS, C.H. Congenital Chagas' disease in Bolivia: epidemiological aspects and pathological findings. Trans. R. Soc. Trop. Med. Hyg., 79:176-80, 1985a.

AZOGUE, E. \& URIOSTE, G. Transmisión congénita de la enfermedad de Chagas en Santa Cruz Bolivia. III - Aspectos clínicos y anatomopatológicos del recien nacido. Boletin Cientifico del Centro Nacional de Enfermedades Tropicales,11:21-30, 1985.

BARUFFA, G. \& ALCANTARA FILHO, A. Comparação entre fixação de complemento em placa, a hemaglutinação e a prova de aglutinação com látex no diagnóstico sorológico da doença de Chagas na zona sul do Rio Grande do Sul. Rev. Soc. Bras. Med. Trop., 9:121-127, 1975.

BITTENCOURT, A.L. Congenital Chagas disease. Am. J. Dis. Child.,130:97-103, 1976.

BITTENCOURT, A.L. Doença de Chagas congênita na Bahia. Rev. Bahiana na Saúde Públ.,11:159, 1984a. 
BITTENCOURT, A.L. Actual aspects and epidemiological significance of congenital transmission of Chagas' disease. Mem. Inst. Oswaldo Cruz,79(Suppl.):133-7, 1984b.

BITTENCOURT, A.L. Doença de Chagas congênita como um problema de saúde pública. Ann. Soc. Belg. Med. Trop.,65(Suppl. 1):103-6, 1985.

BITTENCOURT, A.L. Transmissão materno-infantil. Rev. Soc. Bras. Med. Trop.,20(Supl. 2):M5-M7, 1987.

BITTENCOURT, A.L. Possible risk factors for vertical transmission of Chagas' disease. Rev. Inst. Med. Trop. São Paulo,34:403-8, 1992.

BITTENCOURT, A.L. \& BARBOSA, H.S. Incidência da transmissão congênita da doença de Chagas em abortos. Rev. Inst. Med. Trop. São Paulo, 14:257-9, 1972.

BITTENCOURT, A.L.; BARBOSA, H.S.; ROCHA, T.; SODRE, I.; SODRE, A. Incidência da transmissão congênita da doença de Chagas em partos prematuros na maternidade Tsylla Balbino (Salvador, Bahia). Rev. Inst. Med. Trop. São Paulo,14:131-4, 1972.

BITTENCOURT, A.L.; BARBOSA, H.S.; SANTOS, F.; RAMOS, M.E.A. Incidência de transmissão congênita da doença de Chagas em partos a termo. Rev. Inst. Med. Trop. São Paulo,16:197-9, 1974.

BITTENCOURT, A.L. \& GOMES, M.C. Gestações sucessivas de uma paciente chagásica com ocorrência de casos de transmissão congênita da doença. Gaz. Med. Bahia,67:166-72, 1967.

BITTENCOURT, A.L.; MEDINA-LOPES, M.D.; CAMARGO, M.E. Doença de Chagas. In: DINIZ, E.M.A.; VAZ, F.A.C. Infecções congênitas e perinatais. São Paulo, Ed. Livraria Atheneu, 1991. p. 73-89.

BITTENCOURT, A.L.; MOTA, E.; PÓVOA, M. Isoenzyme characterization of Trypanosoma cruzi from congenital cases of Chagas' disease. Ann. Trop. Med. Parasitol., 79:393-6, 1985a.

BITTENCOURT, A.L.; MOTA, E.; RIBEIRO FILHO, R.; FERNANDES, L.G.; DE ALMEIDA, P.R.; SHERLOCK, I.; MAGUIRE, J.; PIESMAN, J.; TODD, C.W. Incidence of congenital Chagas' disease in Bahia, Brazil. J. Trop. Pediatr.,31:242-8, 1985b. 
BONGERTZ, V. \& CARVALHO, L.C.P. Production of monoclonal antibodies for the identification of a strain of Trypanosoma cruzi. Am. J. Trop. Med. Hyg., 46:435-9, 1992.

BRABIN, L. The epidemiological significance of Chagas' disease in women. Mem. Inst. Oswaldo Cruz,87:73-9, 1992.

BRABIN, L. Trypanosoma cruzi infection in women. Parasitology Today, 9:198-9, 1993.

BRENER, Z. Contaminado: Chagas. Ciência Hoje,9(52):62-3, 1989.

BRENIERE, S.F.; CARRASCO, R.; MIGUEZ, H.; LEMESRE, J.L.; CARLIER, Y. Comparisons of immunological tests for serodiagnosis of Chagas disease in Bolivian patients. Trop. Geogr. Med.,37:231-8, 1985.

BRESLOW, N.E. \& DAY, N.E. Statistical methods in cancer research. Switzerland, International Agency for Research on Cancer, Lyon, 1980. V. 1. Scientific publications No. 32

BRONFEN, E. \& CHIARI, E. Potencial de risco da transmissão transfusional da doença de Chagas em Belo Horizonte (MG). Rev. Soc. Bras. Med. Trop.,21:29-32, 1988.

BUCK, A.A. \& GART, J.J. Comparison of a screening test and a reference test in epidemiologic studies. I. Indices of agreement and their relation to prevalence. Am. J. Epidemiol.,83:586-92, 1966.

CAMARGO, M.E. Fluorescent antibody test for the serodiagnosis of american trypanosomiasis. Technical modification employing preserved culture forms of Trypanosoma cruzi in a slide test. Rev. Inst. Med. Trop. São Paulo,8:227-34, 1966.

CAMARGO, M.E. Reacciones serologicas y consequencias sociales de los resultados positivos a la enfermedad de Chagas. Bol. Of. Sanit. Panam.,72:576-582, 1972.

CAMARGO, M.E.; HOSHINO, S.; SIQUEIRA, G.R.N. Haemagglutination with preserved, sensitized cells, a practical test for routine serologic diagnosis of american trypanosomiasis. Rev. Inst. Med. Trop. São Paulo,15:81-5, 1973.

CAMARGO, M.E.; HOSHINO-SHIMIZU, S.; MACEDO; V.; PERES, B.A.; CASTRO, C. Diagnóstico sorológico da infecção humana pelo Trypanosoma cruzi. Estudo comparativo de testes de fixação do complemento, 
imunofluorescência, hemaglutinação e floculação, em 3.624 soros. Rev. Inst. Med. Trop. São Paulo,19:254-60, 1977.

CAMARGO, M.E. \& REBONATO, C. Cross-reactivity in immunofluorescence test for Trypanosoma and Leishmania antibodies. Am. J. Trop. Med. Hyg., 18:500-505, 1969.

CAMARGO, M.E.; SEGURA, E.L.; KAGAN, I.G.; SOUZA, J.M.P.; CARVALHEIRO, J.R.; YANOVSKY, J.F.; GUIMARÃES, M.C.S. Three years of collaboration on the standardization of Chagas' disease serodiagnosis in the Americas: An appraisal. Bull. Pan Am. Health Organ.,20:233-44, 1986.

CÄMARGO, M.E.; SILVA, G.R.; CASTILHO, E.A.; SILVEIRA, A.C. Inquérito sorológico da prevalência de infecção chagásica no Brasil, 1975-1980. Rev. Inst. Med. Trop. São Paulo,26:192-204, 1984.

CAMARGO, M.E. \& TAKEDA, G.K.F. Diagnóstico de Laboratório In: BRENER, Z. \& ANDRADE, Z. Trypanosoma cruzi e doença de Chagas. Rio de Janeiro, Ed. Guanabara Koogan, 1979. p. 175-98.

CAMPOS, C.; REZENDE, J.M.; RASSI, A. Prevalência de doença de Chagas no banco de sangue do Hospital das Clínicas de Goiânia. Possibilidade de falha da reação de Machado e Guerreiro na seleção de doadores. Rev. Soc. Bras. Med. Trop.,9:165-74, 1975.

CARLIER, Y.; RIVERA, M.T.; TRUYENS, C.; ONTIVERO, M.; FLAMENT, J.; VAN MARCK, E.; DE MAERTELAER, V. Chagas' disease: decreased resistance to Trypanosoma cruzi acquired infection in offspring of infected mice. Am. J. Trop. Med. Hyg., 46:116-22, 1992.

CARRASCO, R.; MIGUEZ, H.; CAMACHO, C.; ECHALAR, L.; REVOLLO, S.; AMPUERO, T.; DEDET, J.P. Prevalence of Trypanossoma cruzi infection in blood banks of seven departaments of Bolivia. Mem. Inst. Oswaldo Cruz,85:69-73, 1990.

CARRASCO, R.L.; BRENIERE, S.F.; POCH, O.; MIGUEZ, H.V.; SELAES, H.; ANTEZANA, G.; DESJEUX, P.; CARLIER, Y. Chagas serology and its problems. Ann. Soc. Belg. Med. Trop.,65(Suppl.1):79-84, 1985.

CASTILHO, E.A. \& SILVA, G.R. Maternal Chagas' infection and prematurity. Rev. Inst. Med. Trop. São Paulo,18:258-60, 1976.

CASTRO FILHO, J. \& SILVEIRA, A.C. Distribuição da doença de Chagas no Brasil. Rev. Bras. Malariol. Doenças Trop.,31:85-98, 1979. 
CATALÁ, S. The biting rate of Triatoma infestans in Argentina. Med. Vet. Entomol., 5:325-33, 1991.

CERISOLA, J.A.; ALVAREZ, M. \& RISSIO, A.M. Imunodiagnóstico da doença de Chagas. Evolução sorológica de pacientes com doença de Chagas. Rev. Inst. Med. Trop. São Paulo,12:403-411, 1970.

CERISOLA, J.A.; FATALA CHABEN, M.; \&LAZZARI, J.O. Test de hemaglutinación para el diagnóstico de la enfermedad de Chagas. Prensa Méd. Arg.,49:1761-1767, 1962.

CERISOLA, J.A.; RABINOVICH, A.; ALVAREZ, M.; CORLETO, C.A.; PRUNEDA, J. Enfermedad de Chagas y la transfusión de sangre. Bol. Of. Sanit. Panam., 73:203-21, 1972.

CETRON, M.S.; HOFF, R.; KAHN, S.; EISEN, H.; VOORHIS, W.C.V. Evaluation of recombinant trypomastigote surface antigens of Trypanosoma cruzi in screening sera from a population in rural Northeastern Brazil endemic for Chagas' disease. Acta Trop.,50:259-66, 1992.

CHUIT, R.; PAULONE, I.; WISNIVESKY-COLLI, C.; BO, R.; PEREZ, A.C.; SOSA-STANI, S.; SEGURA, E.L. Result of a first step toward community-based surveillance of transmission of Chagas'disease with appropriate technology in rural areas. Am. J. Trop. Med. Hyg.,46:444-50, 1992.

CHUIT, R.; SUBIAS, E.; PEREZ, A.C.; PAULONE, I.; WISNIVESKY-COLLI, C.; SEGURA, E.L. Usefulness of serology for the evaluation of Trypanosoma cruzi transmission in endemic areas of Chagas' disease. Rev. Soc. Bras. Med. Trop.,22:119-24, 1989.

CICCHETTI, D.V. \& FEINSTEIN, A.R. High agreement but low Kappa: II. Resolving the paradoxes. J. Clin. Epidemiol.,43:551-8, 1990.

CORRAL, R.S.; ORN, A.; GRINSTEIN, S. Detection of soluble exoantigens of Trypanosoma cruzi by a dot-immunobinding assay. Am. J. Trop. Med. Hyg., 46:31-8, 1992.

COUGHLIN, S.S. \& PICKLE, L.W. Sensitivity and specificity-like measures of the validity of a diagnostic test that are corrected for chance agreement. Epidemiology,3(2):178-80, 1992.

COURA, J.R. Contribuição ao estudo da doença de Chagas no Estado da Guanabara. Rev. Bras. Malariol. Doenças Trop.,18(1):9-98, 1966. 
COUSENS, S.N.; FEACHEM, R.G.; KIRKWOOD, B.R.; MERTENS, T.E.; SMITH, P.G. Case-control studies of childhood diarrhoea: I. Minimising bias. WHO unpublished document CDD/EDP/88.2,1988.

CUNA, W.R.; RODRIGUEZ, C.; TORRICO, F.; AFCHAIN, D.; LOYENS, M.; DESJEUX, P. Evaluation of a competitive antibody enzyme immunoassay for especific diagnosis of Chagas' disease. J. Parasitol.,75:357-9, 1989.

DAO, L. Otros casos de enfermedad de Chagas en el Estado Guarico (Venezuela); formas agudas y cronicas; observación sobre enfermedad de Chagas congénita. Rev. Policlin. Caracas.18(104):17-32, 1949.

DELGADO, M.A. \& SANTOS-BUCH, C.A. Transplacental transmission and fetal parasitosis of Trypanosoma cruzi in outbred white swiss mice. Am. J. Trop. Med. Hyg.,27:1108-15, 1978.

DIAS, J.C.P. Prevalência da doença de Chagas entre crianças da zona rural de Bambui, MG. após ensaio profilático. Rev. Bras. Malariol. Doenças Trop.,29:135-59, 1967.

DIAS, J.C.P. Mecanismos de transmissão. In: BRENER, Z. \& ANDRADE, Z. Trypanosoma cruzi e doença de Chagas. Rio de Janeiro, Ed. Guanabara Koogan, 1979. p. 152-74.

DIAS, J.C.P. Doença de Chagas em Bambui,(MG) Brasil. Estudo clínico epidemiológico a partir da fase aguda, entre 1940 e 1982. Belo Horizonte, 1982. [Tese de Doutorado - Faculdade de Medicina da UFMG].

DIAS, J.C.P. Análise e perspectiva do controle da doença de Chagas no Brasil. Rev. Bras. Malariol. Doenças Trop.,35:109-19, 1983.

DIAS, J.C.P. Control of Chagas disease in Brazil. Parasitology Today,3(11):336-41, 1987.

DIAS, J.C.P. Rural resource development and its potential to introduce domestic vectors into new epidemiological situation. Rev. Argent. Microbiol., 20:81-5, 1988.

DIAS, J.C.P. Chagas disease control in Brazil: which strategy after the attack phase?. Ann. Soc. Belg. Med. Trop.,71(Suppl.1):75-86, 1991.

DIAS, J.C.P. A doença de Chagas e seu controle na América Latina. Uma análise de possibilidades. Cad. Saúde Públ., Rio de Janeiro, 9:201-209, 1993.

DIAS, J.C.P. \& BRENER, S. Chagas' disease and blood transfusion. Mem. Inst. Oswaldo Cruz,79(Suppl.):139-47, 1984. 
DIAS, J.C.P. \& DIAS, R.B. Housing and the control of vectors of human Chaga's disease in the state of Minas Gerais, Brazil. PAHO Bull., 16:117-129, 1982.

DIAZ, C.; NUSSENZWEIG, V.; GONZALEZ, A. An improved polymerase chain reaction assay to detect Trypanosoma cruzi in blood. Am. J. Trop. Med. Hyg., 46:616-23, 1992.

DUFFY, S.W.; MAXIMOVITCH, D.M.; DAY, N.E. External validation, repeat determination, and precision of risk estimation in misclassified exposure data in epidemiology. J. Epidemiol. Community Health,46:620-4, 1992.

DUFFY, S.W.; ROHAN, T.E.; DAY, N.E. Misclassification in more than one factor in a case-control study: a combination of Mantel-Haenszel and maximum likelihood approaches. Stat. Med.,8:1529-36, 1989.

EVANS, A.A.; LEFKOPOULOU, M.; MUELLER, N.E. Methods for inference on transmission in seroprevalence data for multiple infections. Am. J. Epidemiol.,135:1156-65, 1992.

FEINSTEIN, A.R. \& CICCHETTI, D.V. High agreement but low kappa: I. The problems of two paradoxes. J. Clin. Epidemiol.,43:543-9, 1990.

FEITOSA, M.F. \& KRIEGER, H. An appraisal of the epidemiology of Trypanossoma cruzi serology in Brazil. Mem. Inst. Oswaldo Cruz,86:159-67, 1991.

FERREIRA, A.W.; BELEM, Z.R.; MOURA, M.E.G.; CAMARGO, M.E. Aspectos da padronização de testes sorológicos para a doença de Chagas: Um teste imunoenzimático para a triagem de doadores de sangue. Rev. Inst. Med. Trop. São Paulo,33:123-8, 1991.

FIFE JR, E.H. \& MUSCHEL, L.H. Fluorescent-antibody technic for serodiagnosis of Trypanosoma cruzi infection. Proc. Soc. Exp. Biol. Med.,101:540-543, 1959.

FLEISS, J.L. Statistical methods for rates and proportions. $2^{\text {nd }}$ ed. New York, Ed. John Wiley and Sons, 1981.

FLETCHER, R.M.; FLETCHER, S.W.; WAGNER, E.H. Clinical Epidemiology, the essentials. Baltimore - USA, Ed. Wawerly, 1983.

FORATTINI, O.P.; FERREIRA, O.A.; RABELLO, E.X.; BARATA, J.M.S.; SANTOS, J.L.F. Aspectos ecológicos da tripanossomíase americana XVII Desenvolvimento da domiciliação triatomínea regional, em centro de endemismo de Triatoma sordida. Rev. Saúde Pública,17:159-99, 1983a. 
FORATTINI, O.P.; FERREIRA, O.A.; RABELLO, E.X.; BARATA, J.M.S.; SANTOS, J.L.F. Aspectos ecológicos da tripanossomíase americana. XVIII Desenvolvimento e ciclos anuais de colonias de Triatoma infestans, T. sordida e Rhodnius neglectus em ecótopos artificiais, no ambiente peri e extradomiciliar. Rev. Saúde Pública,17:243-62, $1983 b$.

FORATTINI, O.P.; FERREIRA, O.A.; RABELLO, E.X.; BARATA, J.M.S.; SANTOS, J.L.F. Aspectos ecológicos da tripanossomíase americana. XX Desenvolvimento e ciclos anuais de colonias de Panstrongylus megistus em ecótopos artificiais. No ambiente peri e extradomiciliar. Rev. Saúde Pública,18:30-40, 1984.

FORATTINI, O.P.; FERREIRA, O.A.; ROCHA E SILVA, E.O.; RABELLO, E.X. Aspectos ecológicos da tripanossomose americana. V - Observações sobre colonização espontânea de triatomíneos silvestres em ecótopos artificiais, com especial referência ao Triatoma sordida. Rev. Saúde Pública,7:219-39, 1973.

FORATTINI, O.P.; FERREIRA, O.A.; ROCHA E SILVA, E.O.; RABELLO, E.X.; SANTOS, J.L.F. Aspectos ecológicos da tripanossomose americana. II - Distribuição e dispersão local de triatomíneos em ecótopos naturais e artificiais. Rev. Saúde Pública,5:163-91, 1971.

FRASCH, A.C.C.; SANCHEZ, D.O.; CAZZULO, J.J. Prospects of defined proteins for vaccine development. Mem. Inst. Oswaldo Cruz,85:523-9, 1990.

FREILIJ, H.; MULLER, L.; GONZALES CAPPA, S.M. Direct micromethod for diagnosis of acute and congenital Chagas' disease. J. Clin. Microbiol.,18:327-30, 1983.

FREILIJ, H.L.; CORRAL, R.S.; KATZIN, A.M.; GRINSTEIN, S. Antigenuria in infants with acute and congenital Chagas' disease. J. Clin. Microbiol.,25:133-7, 1987.

FREITAS, J.L.P.; AMATO-NETO, V.; SONNTAG, R.; BIANCALANA, A.; NUSSENZWEIG, V.; BARRETO, J.G. Primeiras verificações de transmissão acidental da moléstia de Chagas ao homem por transfusão de sangue. Rev. Paul. Med.,40:36-40, 1952.

FUCHS, A.P.; FIORATTI, V.L.; MELLO, V.A.; BOAINAIN, E. Diagnóstico sorológico na doença de Chagas. Estüdo comparativo de diferentes técnicas. Rev. Inst. Med. Trop. São Paulo,22:242-5, 1980.

FUNDAÇÃO INSTITUTO BRASILEIRO DE GEOGRAFIA E ESTATÍSTICA FIBGE Anuário Estatístico do Brasil. Rio de Janeiro, 1987/1988. v. 48. 
GALEN, R.S. \& GAMBINO, S.R. Beyond normality: the predictive value and efficiency of medical diagnoses. New York, Ed. John Wiley \& Sons, 1975.

GARCIA-ZAPATA, M.T. \& MARSDEN, P.D. Control of the transmission of Chagas' disease in Mambai, Goiás, Brazil (1980-1989). Am. J. Trop. Med. Hyg. ,46:440-3, 1992.

GOLDBAUM, M. Saúde e trabalho. A doença de Chagas no setor industrial. São Paulo, 1981. [Tese de Doutoramento - Faculdade de Medicina da USP].

GÓMEZ-NÚÑEZ, J.C. Desarrollo de un nuevo método para evaluar la infestación intradomiciliaria por Rhodnius prolixus. Acta Cient. Venez.,16:26, 1965.

GORLA, D.E. Seasonal effects on control strategies of Chagas' disease vectors. Rev. Argent. Microbiol.,20(Supl):71-80, 1988.

GORLA, D.E. Recovery of Triatoma infestans populations after insecticide application: an experimental field study. Med. Vet. Entomol.,5:311-24, 1991.

GORLA, D.E. \& SCHOFIELD, C.J. Population dynamics of Triatoma infestans under natural climatic conditions in the Argentine Chaco. Med. Vet. Entomol.,3:179-94, 1989.

GRANT, I.H.; GOLD, J.W.M.; WITTNER, M.; TANOWITZ, H.B.; NATHAN, C.; MAYER, R.; REICH, L.; WOLLNER, N.; STEINHERZ, L.; GHAVIMI, F.; O'REILLY, R.J.; ARMSTRONG, D. Transfusion-associated acute Chagas' disease acquired in the United States. Ann. Intern. Med.,110:849-51, 1989.

GREENBERG, B.G. The future of epidemiology. J. Chronic. Dis.,36(4):353-9, 1983.

GREENLAND, S. The effect of misclassification in matched-pair case-control studies. Am. J. Epidemiol.,116:402-6, 1982.

GUERREIRO, C. \& MACHADO, A. Da reação de Bordet e Gengou na moléstia de Carlos Chagas como elemento diagnóstico. Brasil-med., 27:225-6, 1913.

GUIMARÃES, M.C.S. Exames de laboratório: sensibilidade, especificidade, valor preditivo positivo. Rèv. Soc. Bras. Med. Trop.,18:117-20, 1985.

GUIMARÃES, M.C.S.; CAMARGO, M.E.; FERREIRA, A.W.; CASTILHO, E.A.; NAKAHARA, O.S. Comparison of IgG and IgM contents in serum and filter paper blood eluates. Am. J. Trop. Med. Hyg..27:350-3, 1978.

GUIMARÃES, M.C.S.; CASTILHO, E.A.; CELESTE, B.J.; NAKAHARA, O.S.; AMATO NETTO, V. Almacenamiento a largo plazo de IgG e IgM en papel 
filtro para su uso en encuestas seroepidemiológicas de enfermedades parasitarias. Bol. Of. Sanit. Panam.,100(2):129-44, 1986.

GUIMARÃES, M.C.S.; COUTINHO, S.G.; ANTUNES, C.M.F. Normas para a sorologia de moléstias parasitárias. Rev. Soc. Bras. Med. Trop.,20:55-8, 1987.

GUINSBURG, R. \& KOPELMAN, B.I. Positive serology for Chagas' disease among women from nonendemic urban areas. Rev. Hosp. Clín. São Paulo,1(2):50-4, 1989.

GÜTLER, R.E.; CECERE, M.C.; RUBEL, D.N.; PETERSEN, R.M.; SCHWEIGMANN, N.J.; LAURICELLA, M.A.; BUJAS, M.A.; SEGURA, E.L.; WISNIVESKY-COLLI, C. Chagas disease in north-west Argentina: infected dogs as a risk factor for the domestic transmission of Trypanosoma cruzi. Trans. R. Soc. Trop. Med. Hyg.,85:741-5, 1991.

GÜRTLER, R.E.; SOLARZ, N.D.; LAURICELLA, M.A.; HAEDO, A.S.; PIETROKOWSKY, S.M.; ALBERTI, A.A.; WISNIVESKY-COLLI, C. Dynamics of transmission of Trypanosoma cruzi parasitemia among canine reservoirs in a two-year follow-up. Rev. Inst. Med. Trop. São Paulo,28:213-9, 1986.

GÜRTLER, R.E.; WISNIVESKY-COLLI, C.; SOLARZ, N.; LAURICELLA, M.; BUJAS, M.A. Dynamics of transmission of Trypanosoma cruzi in a rural area of Argentina: II. Household infection patterns among children and dogs relative to the density of infected Triatoma infestans. Bull. Pan. Am. Health Organ.,21(3):280-92, 1987.

HALLORAN, M.E. \& STRUCHINER, C.J. Study designs for dependent happenings. Epidemiology, 2:331-8, 1991.

HAYES, R.J. \& SCHOFIELD, C.J. Estimación de las tasas de incidencia de infecciones y parasitosis crónicas a partir de la prevalencia: la enfermedad de Chagas en America Latina. Bol. Of. Sanit. Panam.,108:308-16, 1990.

HENNEKENS, C.H. \& BURING, J.E. Epidemiology in Medicine. $5^{\text {th }}$ ed. Boston/Toronto, Ed. Little, Brown and Company, 1987.

HOFF, R.; TODD, C.W.; MAGUIRE, J.H.; PIESMAN, J.; MOTT, K.E.; MOTA, E.E.; SLEIGH, A.; SHELOCK, I.A.; WELLER, T.H. Serologic surveillance of Chagas' disease. Ann. Soc. Belg. Med. Trop.,65(Suppl. 1):187-96, 1985.

HOSHINO-SHIMIZU, S.; NAGASSE-SUGAHARA, T.K.; CASTILHO, E.A.; CAMARGO, M.E.; SHIMIZU, T. A control chart method for evaluating 
hemagglutination reagent used in Chagas'disease diagnosis. Bull. Pan Am. Health Organ., 20(2):170-8, 1986.

HOWARD, J.E. \& RUBIO, M. Congenital Chagas' disease. I. Clinical and epidemiological study of thirty cases. Bol. Chil. Parasitol.,23:107-12, 1968.

HUBSCH, R.M.; CHIECHIE, N.; COMACH, G.; ALDAO, R.R.; GUSMÃO, R.D. El ensayo inmunoenzimático en microgotas sobre nitrocelulosa (Dot-ELISA) en el diagnóstico de la enfermedad de Chagas. II. Estudio seroepidemiológico en cuatro comunidades rurales de Venezuela. Mem. Inst. Oswaldo Cruz,84:401-8, 1989.

HULKA, B.S. \& MARGOLIN, B.H. Methodological issues in epidemiologic studies using biologic markers. Am. J. Epidemiol.,135:200-9, 1992.

KIRCHHOFF, L.V. Is Trypanosoma cruzi a new threat to our blood supply?. Ann. Intern. Med.,111):773-5, 1989.

KLEINBAUM, D.G.; KUPPER, L.L.; MORGENSTERN, H. Epidemiologic Research. New York, Ed. Van Nostrand Reinhold, 1982.

KNIERIM, F. Técnica de la reaccion de fijación del complemento según el método del 50\% de hemólisis en el diagnostico de la enfermedad de Chagas. Bol. Chile. Parasit., 14:5-6, 1958.

KOPEC, J.A. \& ESDAILE, J.M. Bias in case-control studies. A review. J. Epidemiol. Community Health,44:179-86, 1990.

KRAEMER, H.C. \& BLOCH, D.A. Kappa coefficients in epidemiology: a appraisal of a reappraisal. J. Clin. Epidemiol.,41:959-68, 1988.

KRIEGER, M.A.; ALMEIDA, E.; OELEMANN, W.; LAFAILLE, J.J.; PEREIRA, J.B.; KRIEGER, H.; CARVALHO, M.R.; GOLDENBERG, S. Use of recombinant antigens for the accurate immunodiagnosis of Chagas' disease. Am. J. Trop. Med. Hyg., 46:427-34, 1992.

LENT, H. \& WYGODZINSKY, P. Revision of the Triatominae (Hemiptera, Reduviidae), and theirs significance as vectors of Chagas' disease. Bull. Am. Mus. Nat. Hist., 163(3):127-520, 1979.

LITVOC, J.; GOLDBAUM, M.; SILVA, G.R. Determinantes do processo de infestação domiciliar por Panstrongylus megistus: o papel da habitação e do desmatamento. Rev. Inst. Med. Trop. São Paulo,32:443-9, 1990. 
LOMBARDI, C.; COHEN, S.; LEIKER, D.L.; SOUZA, J.M.P.; CUNHA, P.R.; MARTELLI, C.M.T.; ANDRADE, A.L.S.S.; ZICKER, F. Agreement between histopathological results in clinically diagnosed cases of indeterminate leprosy in São Paulo, Brazil. Acta Leprol., 1994 [no prelo].

LONGINI JR, I.M.; KOOPMAN, J.S.; HABER, M.; COTSONIS, G.A. Statistical inference for infectious diseases. Am. J. Epidemiol.,128:845-59, 1988.

LUQUETTI, A.O. Use of Trypanosoma cruzi defined proteins for diagnosis-multicentre trial $(+)$ serological and technical aspects. Mem. Inst. Oswaldo Cruz,85:497-505, 1990.

LUSTOSA, E.S.; NAVES, H.A.M.; CARVALHO, M.E.S.D.; CALIL, F;; MATOS, C.A.S. Distribuição geográfica de triatomíneos encontrados nos domicílios e peridomicílios nas micro-regiões do Estado de Goiás. Rev. Goiana Med.,30:49-54, 1984.

MACLURE, M. \& WILLETT, W.C. Misinterpretation and misuse of the Kappa statistic. Am. J. Epidemiol.,126:161-9, 1987.

MAGUIRE, J.H.; HOFF, R.; SHERLOCK, I.; GUIMARAES, A.C.; SLEIGH, A.C.; RAMOS, N.B.; MOTT, K.E.; WELLER, T.H. Cardiac morbidity and mortality due to Chagas' disease: prospective electrocardiographic study of a Brazilian community. Circulation,75:1140-5, 1987.

MANTEL, N. \& HAENSZEL, W. Statistical aspects of the analysis of data from retrospective studies of disease. J. Natl. Cancer Inst.,22:719-48, 1959.

MARSDEN, P.D.; MOTT, K.E.; PRATA, A. The prevalence of Trypanosoma cruzi parasitemia in 8 families in an endemic area. Gaz. Med. Bahia,69:65-9, 1969.

MARSDEN, P.D.; VIRGENS, D.; MAGALHAES, I.; TAVARES-NETO, J.; FERREIRA, R.; COSTA, C.H.; CASTRO, C.N.; MACEDO, V.; PRATA, A. Ecologia doméstica do Triatoma infestans em Mambai, Goiás-Brasil. Rev. Inst. Med. Trop. São Paulo,24:364-73, 1982.

MARTELLI, C.M.T.; ANDRADE, A.L.S.S.; CARDOSO, D.D.P.; SILVA, S.A.; ZICKER, F. Considerações metodológicas na interpretação do rastreamento sorológico da hepatite B em doadores de sangue. Rev. Saúde Pública,25:11-6, 1991.

MARTELLI, C.M.T.; ANDRADE, A.L.S.S.; SILVA, S.A.; ZICKER, F. Risk factors for Trypanosoma cruzi infection among blood donors in central Brazil. Mem. Inst. Oswaldo Cruz,87:339-43, 1992. 
MEDINA-LOPES, M.D. Transmissão materno-infantil da doença de Chagas. Rev. Goiana Med.,30:91-5, 1984.

MELLO, D.A. Aspecto do ciclo silvestre do Trypanossoma cruzi em regiões de cerrado (município de Formosa, Estado de Goiás). Mem. Inst. Oswaldo Cruz,76:227-46, 1981.

MINISTÉRIO DA SAÚDE, BRASIL. Portaria $\mathrm{n}^{0} 721$ de 09.08.89: dispõe sobre normas técnicas para a coleta, processamento e transfusão de sangue, componentes e derivados. Diário Oficial da União, Brasília 11.08.89.

MINTER, D.M.; MINTER-GOEDBLOED, E.; MARSDEN, P.D.; MILES, M.A.; MACEDO, V. Domestic risk factor-an attempt to assess risk of infection with Trypanosoma cruzi in houses in Brazil. Trans. R. Soc. Trop. Med. Hyg., 67:290, 1973.

MINTER-GOEDBLOED, E.; MINTER, D.M.; MARSHAL, T.F.C. Quantitative comparison between xenodiagnosis and haemoculture in detection of Trypanosoma (Shizotrypanum) cruzi in experimental and natural chronic infections. Trans. R. Soc. Trop. Med. Hyg., 72:217, 1978.

MONCAU, J.E.C. Análise estratificada em estudos caso-controle. São Paulo, 1991. [Dissertação de Mestrado - Faculdade de Saúde Pública da USP].

MONCAYO, A. Chagas disease: epidemiology and prospects for interruption of transmission in the Americas. World Health Stat Q.,45(2-3):276-9, 1992.

MONCAYO, A. \& LUQUETTI, A.O. Multicentre double blind study for evaluation of Trypanosoma cruzi defined antigens as diagnostic reagents $(+)$. Mem. Inst. Oswaldo Cruz,85:489-95, 1990.

MOTA, C.C.C. Doença de Chagas congênita: Estudo longitudinal das repercussões da infecção materna no concepto, do nascimento aos cinco anos de idade. Belo Horizonte, 1992. [Tese de Doutoramento - Faculdade de Medicina da UFMG].

MOTA, E.; RIBEIRO FILHO, R.; MENEZES, G.M. Perdas fetais em uma área rural endêmica para a doença de Chagas no Estado da Bahia. Rev. Pat. Trop.,14(2):131-40, 1985.

MOTA, E.A.; GUIMARÃES, A.C.; SANTANA, O.O.; SHERLOCK, I.; HOFF, R.; WELLER, T.H. A nine year prospective study of Chagas' disease in a defined rural population in northeast Brasil. Am. J. Trop. Med. Hyg. 42:429-40, 1990.

MOTT, K.E.; LEHMAN JR, J.S.; HOFF, R.; MORROW, R.H.; MUNIZ, T.M.; SHERLOCK, I.; DRAPER, C.C.; PUGLIESE, C.; GUIMARAES, A.C. The 
epidemiology and household distribution of seroreactivity to Trypanosoma cruzi in a rural community in nor theast Brazil. Am. J. Trop. Med. Hyg., 25: 552-62, 1976.

MOTT, K.E.; MUNIZ, T.M.; LEHMAN JR, J.S.; HOFF, R.; MORROW JR, R.H.; OLIVEIRA, T.S.; SHERLOCK, I.A.; DRAPER, C.C. House construction, triatomine distribution, and household distribution of seroreactivity to Trypanosoma cruzi in a rural community in northeast Brazil. Am. J. Trop. Med. Hyg., 27:1116-22, 1978.

NATTAN-LARRIER, L. Hérédité des infections expérimentales a Schizotrypanum cruzi. Bull. Soc. Pathol. Exot.,14(4):232-8, 1921.

NICKERSON, P.; ORR, P.; SCHROEDER, M.L.; SEKLA, L.; JOHNSTON, J.B. Transfusion-Associated Trypanosoma cruzi infection in a non-endemic area. Ann. Int. Med.,111:851-3, 1989:

NUSSENZWEIG, V.; AMATO NETO, V.; FREITAS, J.L.P.; NUSSENZWEIG, R.S.; BIANCALANA, A. Moléstia de Chagas em bancos de sangue. Rev. Hosp. Clín. Fac. Med. São Paulo,10:265-83, 1955.

NUSSENZWEIG, V.; SONNTAG, R.; BIANCALANA, A.; FREITAS, J.L.P.; AMATO NETO, V.; KLOETZEL, J. Ação de corantes tri-fenil-metanicos sobre o Trypanosoma cruzi "in vitro". Emprego da violeta de genciana na profilaxia da transmissão da moléstia de Chagas por transfusão de sangue. $\mathbf{O}$ Hospital,44:731-44, 1953.

OLIVEIRA, F.C.; CHAPADEIRO, E.; ALONSO, M.T.; LOPES, E.R.; PEREIRA, F.E.L. Doença de Chagas e gravidez I - Incidência da tripanosomíase e abortamento espontâneo em gestantes chagásicas crônicas. Rev. Inst. Med. Trop. São Paulo.8(4):184-5, 1966.

ORGANIZAÇÃO PANAMERICANA DA SAÚDE - OPS. Guias para el estudio y control de la enfermedad de Chagas. Maracay, Centro de Investigaciones y Referencia sobre la Biologia y Control de Vetores, 1-70, 1978.

ORGANIZAÇÃO PANAMERICANA DA SAÚDE - OPS. Taller internacional sobre el control de la enfermedad de Chagas. Montevidéo,1-53, 1991.

PAN, A.A.; ROSENBERG, G.B.; HURLEY, M.K.; SCHOCK, G.J.H.; CHU, V.P.; AIYAPPA, A. Clinical evaluation of an EIA for the sensitive and specific detection of serum antibody to Trypanosoma cruzi (Chagas'Disease). J. Infect. Dis.,165:585-8, 1992. 
PAULONE, I.; CHUIT, R.; PEREZ, A.C.; CANALE, D.; SEGURA, E.L. The status of transmission of Trypanossoma cruzi in an endemic area of Argentina prior to control attempts, 1985. Ann. Trop. Med. Parasitol.,85:489-97, 1991.

PEARCE, N. Analytical implications of epidemiological concepts of interaction. Int. J. Epidemiol.,18:976-80, 1989.

PETRAY, P.; BONARDELLO, N.; CLARK, R.; AGRANATTI, M.; CORRAL, R.; GRINSTEIN, S. Evaluación del método de ELISA para detección de antígenos y complejos inmunes circulantes de Trypanosoma cruzi atraves de un estudio de campo en una zona endemica de Argentina. Rev. Inst. Med. Trop. São Paulo,34:141-7, 1992.

PIESMAN, J.; SHERLOCK, I.A.; CHRISTENSEN, H.A. Host availability limits population density of Panstrongylus megistus. Am. J. Trop. Med. Hyg.,32:1445-50, 1983.

PIESMAN, J.; MOTA, E.; SHERLOCK, I.A.; TODD, C.W. Trypanosoma cruzi: Association between seroreactivity of children and infection rates in domestic Panstrongylus megistus (Hemiptera: Reduviidae). J. Med. Entomol, 22(2):130-3, 1985a.

PIESMAN, J.; SHERLOCK, I.A.; MOTA, E.; TODD, C.W.; HOFF, R.; WELLER, T.H. Association between household triatomine density and incidence of Trypanosoma cruzi infection during a nine-year study in Castro Alves, Bahia, Brazil. Am. J. Trop. Med. Hyg.,34:866-9, 1985 b.

PLESS, M.; JURANEK, D.; KOZARSKY, P.; STEURER, F.; TAPIA, G.; BERMUDEZ, $\mathrm{H}$. The epidemiology of Chagas' disease in a hyperendemic area of Cochabamba, Bolivia: A clinical study including electrocardiography, seroreactivity to Trypanosoma cruzi, xenodiagnosis, and domiciliary triatomine distribution. Am. J. Trop. Med. Hyg., 47:539-46, 1992.

PRATA, A.; MAYRINK, W.; SODRE, A.G.; ALMEIDA, J.O. Discrepâncias entre resultados de reações de Guerreiro-Machado executadas em diferentes laboratórios. Rev. Soc. Bras. Med. Trop.,10(2):103-5, 1976.

RABINOVICH, J.E.; WISNIVESKY-COLLI, C.; SOLARZ, N.D.; GURTLER, R.E. Probability of transmission of Chagas disease by Triatoma infestans (Hemiptera: Reduviidae) in endemic area of Santiago del Estero, Argentina. Bull. World Health Organ.,68:737-46, 1990.

RASSI, A.; AMATO NETO, V.; SIQUEIRA, A.F. Comportamento evolutivo da reação de fixação do complemento na fase crônica da moléstia de Chagas. Rev. Inst. Med. Trop. São Paulo,11:430, 1969. 
RASSI, A. \& REZENDE, J.M. Prevention of transmission of T. cruzi by blood transfusion. Medicina - Cirugia - Farmacia, 159:399-401,1975.

REZENDE, J.M.; ZUPELLI, W.; BAFUTTO, M.G. O problema da transmissão da doença de Chagas por transfusão de sangue. Emprego da violeta de genciana como medida profilática. Rev. Goiana Med.,11:35-47, 1965.

RODRIGUES, L. \& KIRKWOOD, B.R. Case-control designs in the study of common diseases: updates on the demise of the rare disease assumption and the choice of sampling scheme for controls. Int. J. Epidemiol.,19:205-213, 1990.

ROSENBAUM, M.B. \& CERISOLA, J.A. Epidemiología de la enfermedad de Chagas en la República Argentina. O Hospital.60(1):75-123, 1961.

SACKETT, D.L. Bias in analytic research. J. Chron. Dis.,32:51-63, 1979.

SALAZAR, H.J.; ARENDS, T.; MAEKELT, G.A. Comprobación en Venezuela de la transmisión del Schizotrypanum cruzi por transfusión de sangre. Arch. Venez. Med. Trop. Parasitol., 4:355-63, 1962.

SALVATELLA, R.; CALEGARI, L.; CASSERONE, S.; CIVILA, E.; CARBAJAL, S.; PEREZ, G.; SOMMA, R.; SAMPAIO, I.; LLANES, M.E.; CONTI, M.; PAULERCI, C.; CONTI-DIAZ, I.A.; SOMMA-MOREIRA, R.; PEREZ MOREIRA, L. Seroprevalencia de anticuerpos contra Trypanosoma cruzi en 13 departamentos del Uruguay. Bol. Sanit. Panam.,107(2):108-17, 1989.

SCHATTSCHNEIDER, W.; LOPES, E.R.; DE ALENCAR, J.E.; BIENZLE, U.; FELDMEIER, H. A comparative study of four serological methods for diagnosis of acute and chronic Chagas' disease in Brazilian patients. Trop. Geogr. Med., 44(3):210-8, 1992.

SCHLEMPER JUNIOR, B.R. Estudos experimentais de quimioprofilaxia da transmissão da doença de Chagas por transfusão sanguínea. Rev. Pat. Trop.,7(1,2):55-111, 1978.

SCHLESSELMAN, J.J. Case-control studies - Design, conduct and analysis. New York, Ed. Oxford University Press, New York,1982.

SCHMUÑIS, G.A. Trypanosoma cruzi, the etiologic agent of Chagas' disease: status in the blood supply in endemic and nonendemic countries. Transfusion,31:547-57, 1991.

SCHOFIELD, C.J. A comparison of sampling techniques for domestic populations of Triatominae. Trans. R. Soc. Trop. Med. Hyg., 72:449-55, 1978. 
SCHOFIELD, C.J. Density regulation of domestic populations of Triatoma infestans in Brazil. Trans. R. Soc. Trop. Med. Hyg.,74:761-9, 1980.

SCHOFIELD, C.J. Vector population responses to control interventions. Ann. Soc. Belg. Med. Trop.,71(Suppl.1):201-17, 1991.

SCHOFIELD, C.J. Eradication of Triatoma infestans: a new regional programme for southern Latin America. Ann. Soc. Belg. Med. Trop.,72(Suppl. 1):69-70, 1992.

SCHOFIELD, C.J. \& DIAS, J.C.P. A cost-benefit analysis of Chagas disease control. Mem. Inst. Oswaldo Cruz,86:285-95, 1991.

SEGURA, E.L.; PEREZ, A.C.; YANOVSKŸ, J.F.; ANDRADE, J.; WYNNE DE MARTINI, G.J. Decrease in the prevalence of infection by Trypanosoma cruzi (Chagas' disease) in young men of Argentina. Bull. Pan Am. Health Organ.,19(3):252-64, 1985.

SEIGEL, D.G.; PODGOR, M.J.; REMALEY, N.A. Acceptable values of Kappa for comparison of two groups. Am. J. Epidemiol.,136:571-8, 1992.

SERC. Statistical and Epidemiological Research Corporation. EGRET Epidemilogical, Graphics, Estimation and Testing package. Seattle, WA USA, Version 0.19.6, 1991.

SILVA, G.R.; LITVOC, J.; GOLDBAUM, M.; DIAS, J.C.P. Aspectos da epidemiologia da doença de Chagas. Ciência e Cultura,31 (Supl.): 81-103, 1979.

SILVA, I.G. Influência da temperatura na biologia de triatomíneos . I. Triatoma rubrovaria (Blanchard, 1843) (Hemiptera , Reduviidae). Rev. Goiana Med.,31:1-37, 1985.

SILVA, I.G. Nova técnica para leitura do xenodiagnóstico. Rev. Goiana Med.,36:35-9, 1990.

SILVA, I.G. \& LUSTOSA, E.S. Biologia de Psammolestes tertius Lent \& Jurberg, 1965 (Hemiptera,Reduviidae). Rev. Pat. Trop.,22(1):29-42, 1993.

SILVA, I.G; SILVA J.L.; SILVA, H.H.G.; CAMARGO, M.F.; MOURA, A.F.; ELIAS, M. \& SANTOS, A.H. Distribuição dos vetores da tripanosomíase americana capturados no ambiente domiciliar, no Estado de Goiás, período de 1984/1988. An. Soc. Ent. Brasil,21(2):139-154, 1992. 
SILVEIRA, A.C.; FEITOSA, V.R.; BORGES, R. Distribuição de triatomíneos capturados no ambiente domiciliar, no período 1975/83, Brasil. Rev. Bras. Malariol. Doenças Trop.,36:15-9, 1984.

SMITH, P.G. \& DAY, N.E. The design of case-control studies: The Influence of confounding and interaction effects. Int. J. Epidemiol.,13:356-65, 1984.

SOUSA, O.E. Relationship between vector species and their vectorial capacity for certain strains of T. cruzi. Rev. Argent. Microbiol.,20(Supl):63-70, 1988.

SOUZA, A.G.; VALÉRIO-WANDERLEY, D.M.; BURALLI, G.M.; ANDRADE, J.C.R. Consolidation of the control of Chagas' disease vectors in the state of São Paulo. Mem. Inst. Oswaldo Cruz,79(suppl.):125-31, 1984.

SOUZA, H.M. Quimioprofilaxia da doença de Chagas transfusional. Realidade atual. Rev. Soc. Bras. Med. Trop.,22:1-3, 1989.

SOUZA, H.M.; MORAIS, C.A.; MINEO, J.R. Prevalência da infecção chagásica em doadores de sangue no Triângulo Mineiro. Rev. Soc. Bras. Med. Trop.,18:11-6, 1985.

SOUZA, J.M.P. \& BENÍCIO, M.H.D'A. Análise multivariada; um exemplo usando modelo log-linear. Rev. Saúde Pública,19:263-9, 1985.

SPITZNAGEL, E.L. \& HELZER, J.E. A proposed solution to the base rate problem in the Kappa statistic. Arch. Gen. Psychiatry,42:725-8, 1985.

SPSS Statistical Package for Social Science/PC. SPSS Inc. Marija J Norusis, Versão 4.0. Chicago, 1990.

STARR, M.D.; ROJAS, J.C.; ZELEDÓN, R.; HIRD, D.W.; CARPENTER, T.E. Chagas' Disease : Risk factors for house infestation by Triatoma dimidiata, the major vector of Trypanosoma cruzi in Costa Rica. Am. J. Epidemiol.,133:740-7, 1991.

THOMPSON, W.D. \& WALTER, S.D. A reappraisal of the Kappa coefficient. J. Clin. Epidemiol., 41:949-58, 1988.

URY, H.K. Efficiency of case-control studies with multiple controls per case: continuous or dichotomous data. Biometrics,31:643-9, 1975.

VERGARA, U.; VELOSO, C.; GONZALES, A.; LORCA, M. Evaluation of an enzyme-linked immunosorbent assay for the diagnosis of Chagas' disease using synthetic peptides. Am. J. Trop. Med. Hyg.,46:39-43, 1992. 
VICTORA; C.G.; KIRKWOOD, B.R.; FUCHS, S.C.; LOMBARDI, C.; BARROS, F.C. Is it possible to predict which diarrhoea episodes will lead to life-threatening dehydration?. Int. J. Epidemiol.,19:736-42, 1990.

VILLELA, E. A transmissão intra-uterina da moléstia de Chagas; nota previa. Folha Med.,4(6):41-3, 1923.

VOLLER, A.; DRAPER, C.; BIDWELL, D.E.; BARTLETT, A. Microplate enzyme-linked immunosorbent assay for Chagas' disease. Lancet,1:426-8, 1975.

WACHOLDER, S.; MCLAUGHLIN, J.K.; SILVERMAN, D.T.; MANDEL, J.S. Selection of controls in case-control studies. I. Principles. Am. J. Epidemiol.,135:1019-28, 1992a.

WACHOLDER, S.; SILVERMAN, D.T.; MCLAUGHLIN, J.K.; MANDEL, J.S. Selection of controls in case-control studies. II. Types of controls. Am. J. Epidemiol.,135:1029-41, $1992 \mathrm{~b}$.

WACHOLDER, S.; SILVERMAN, D.T.; MCLAUGHLIN, J.K.; MANDEL, J.S. Selection of controls in case-control studies. III. Design options. Am. J. Epidemiol.,135:1042-50, 1992c.

WANDERLEY, D.M.V. Vigilância entomológica da doença de Chagas no Estado de São Paulo. Rev. Saúde Pública,25:28-32, 1991.

WISNIVESKY-COLLI, C.; GÜRTLER, R.E.; SOLARZ, N.D.; LAURICELLA, M.; SEGURA, E.L. Epidemiological role of humans, dogs and cats in the transmission of Trypanosoma cruzi in central area of Argentina. Rev. Inst. Med. Trop. S. Paulo, 27:346-352, 1985.

WISNIVESKY-COLLI, C.; PAULONE, I.; PEREZ, A.; CHUIT, R.; GUALTIERI,J.; SOLARZ, N.; SMITH, A.; SEGURA, E.L. A new tool for continuous detection of the presence of Triatomine bugs, vectors of Chagas disease, in rural households. Medicina (B. Aires) ,47:45-50, 1987.

WORLD HEALTH ORGANIZATION - WHO. Chagas disease. Frequency and geographical distribution. Wkly. Epidem. Rec., 65:257-261, 1990.

WORLD HEALTH ORGANIZATION - WHO. Encuentro Latinoamericano sobre "Sistemas de vigilancia para evaluar el impacto de los programas de control de la enfermedad de Chagas". Córdoba, 1991a. (PNUD/BANCO MUNDIAL/OMS/PROGRAMA ESPECIAL DE LA OMS DE INVESTIGACIONES Y ENSEÑANZAS SOBRE ENFERMEDADES TROPICALES). 
WORLD HEALTH ORGANIZATION - WHO. Tropical diseases: progress in research, 1989-1990. Geneva, 1991b. (Tenth programme report of the UNDP/World Bank/WHO Special Programme for Research and Training in Tropical Diseases).

WORLD HEALTH ORGANIZATION - WHO. Control of Chagas disease: report of a WHO Expert Committee. Geneva, 1991c. (WHO Technical Report Series, 811).

ZAIDENBERG, M. \& SEGOVIA, A. Enfermedad de Chagas congénita en la ciudad de Salta, Argentina. Rev. Inst. Med. Trop. São Paulo,35:35-43, 1993.

ZELEDÓN, R. \& VARGAS, L.G. The role of dirt floors and of firewood in rural dwellings in the epidemiology of Chagas' disease in Costa Rica. Am. J. Trop. Med. Hyg.,33:232-5, 1984.

ZICKER, F. Chagas' disease and social, security. A case-control study in an urban area, Goiás, Brazil. Rev. Saúde Pública,22:281-7, 1988.

ZICKER, F.; OLIVEIRA, R.M.; LUQUETTI, A.O.; OLIVEIRA, O.S.; SMITH, P.G. Seroprevalence of Trypanosoma cruzi infection among unskilled urban workers in central Brazil. Trans. R. Soc. Trop. Med. Hyg.,83:511-3, 1989.

ZICKER, F.; ALMEIDA NETTO, J.C.; ZICKER, E.M.S.; OLIVEIRA, R.M.; SMITH, P. Trypanosoma cruzi infection and electrocardiographic findings among active manual workers. A population-based study in central Brazil. Int. J. Epidemiol.,19:182-6, 1990a.

ZICKER, F.; MARTELLI, C.M.T.; ANDRADE, A.L.S.S.; SILVA, S.A. Trends of T. cruzi infection based on data from blood bank screening. Rev. Inst. Med. Trop. São Paulo,32:132-7, 1990b.

ZICKER, F.; SMITH, P.G.; ALMEIDA NETTO, J.C.; OLIVEIRA, R.M.; ZICKER, E.M.S. Physical activity, opportunity for reinfection, and sibling history of heart disease as risk factors for Chagas' cardiopathy. Am. J. Trop. Med. Hyg., 43(5):90-147, 1990c.

ZICKER, F.; SMITH, P.G.; LUQUETTI, A.O.; OLIVEIRA, O.S. Mass screening for Trypanosoma cruzi infections using immunofluorescence, ELISA and haemagglutination tests on serum samples and on blood eluates from filter-paper. Bull. World Health Organ.,68:465-71, 1990d. 
ZICKER, F.; ZICKER, E.M.S.; OLIVEIRA, J.J.; NETTO, J.C.A.; OLIVEIRA, R.M.; SMITH, P.G. Exercise electrocardiogram tests in manual workers with and without antibodies to Trypanosoma cruzi: a population-based study. Trans. R. Soc. Trop. Med. Hyg.,84:787-91, 1990e.

ZUNA, H.; LA FUENTE, C.; VALDEZ, E.; RECACOECHEA, M.; FRANCO, J.L.; ROMERO, A.; BERMUDEZ, H. Estudio prospectivo de la transmisión del Trypanosoma cruzi por via sanguinea, en Bolivia. Ann. Soc. Belg. Med. Trop.,65(Supl. 1):107-13, 1985. 
ANEXO 1

ENSAIO DE CAMPO ALEATÓRIO COM BENZONIDAZOL EM CRIANÇAS COM INFECÇÃO PELO T.cruzi

UFG/TDR/WHO

\section{TRIAGEM SOROLÓGICA}

\section{IDENTIFICAÇÃO}

1. Número

NO

2. Escola ESC

3. Endereço

4. Município MUN

5. Nome

Pai

Mãe

6. Sexo Masculino (1) Feminino (2)

SEX $\quad(\quad)$

7. Idade anos

8. Endereço da casa

Referência

RESULTADOS ELUATO

DATA

9. HAI

10. ELISA

11. IFI

12. CONCLUSÃO DO ELUATO
EHA $\quad(\quad)$

EEL ( )

EIF RESULTADO

$\begin{array}{lll}\ldots \ldots . . & \text { EHA } & (\quad) \\ \ldots \ldots \ldots & \text { EEL } & (\quad) \\ \ldots \ldots . . & \text { EIF } & (\quad)\end{array}$
Neg (1) Pos (2) Duvidoso (3) 


\section{ANEXO 2}

WHO/UFG/IPTESP

DSC/SUCAM

\section{ESTUDO EPIDEMIOLÓGICO EM ESCOLARES \\ QUESTIONÁRIO}

\section{IDENTIFICAÇÃO}

Controle (0) Caso (1)

Idade

Sexo Masc (1) Fem (2)

Data nascimento

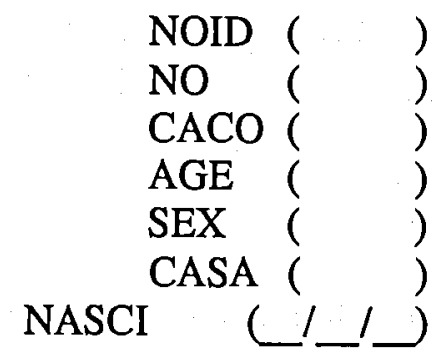

Nome

Escola Nasc

Professora

Endereço

Comunidade

$\operatorname{COM}(\quad)$

Município

Responsável

Data entrevista

Entrevistador

\section{HISTÓRIA DE RESIDÊNCIA}

2.1 Pergunte sobre locais de residência desde o nascimento.

Idade Local resid - urbano tipo de teto piso cidade/estado rural casa

1. Nasc

2.

3. 
4.

5.

Codifique em relação à moradia atual zona urbana (1) zona rural (2)

UR

Casa (parede):

tijolo $\mathrm{c} /$ reboque (1) tijolo $\mathrm{s} /$ reboque (2) pau-a-pique $\mathrm{c} /$ reboque (3) madeira (4) adobe s/ reboque (5) folha de palmeira ou similar (6) barro c/ madeira (7) tijolo / pintada (8) adobe / pintada (9) adobe c/ reboque (10) outros (11)

PA $\quad(\quad)$

Teto:

telha de barro (1) telha de cimento amianto (2) capim (3) zinco (4) folha de palmeira (5) buriti (6) indaiá (7) guariroba (8) outros(9)

TETO ( )

Piso:

terra (1) cimento (2) madeira (3) tijolo (4) outros (5)

PISO ( )

Codifique de acordo com a história de residência (anos de moradia em zona rural)

$\operatorname{YEXP}(\quad)$

\section{AVALIAÇÃO DA RESIDÊNCIA ATUAL}

Número de cômodos

$\operatorname{NCOM}(\quad)$

Número de moradores na casa

NPES ( )

Tempo de moradia anos

YMOR ( )

Característica da moradia

Codifique Não (1) Sim (2)

Casa própria?

Estoque de alimentos dentro de casa?

Montes de lenha dentro de casa?

Montes de telha dentro de casa?

Montes de tijolo dentro de casa? 
Montes de pedra dentro de casa?

Animais vivendo dentro de casa?

Galinha

Cão

Porco

Gato

Outros

Presença de roedores e/ou gambá dentro de casa

$\begin{array}{ll}\text { GAL } & (\quad) \\ \text { CAO } & (\quad) \\ \text { POR } & (\quad) \\ \text { GAT } & (\quad) \\ \text { OUT } & (\quad) \\ \text { ROED } & (\quad)\end{array}$

Caracterização dos arredores e anexos

Codifique Não (1) Sim (2)

Presença de:

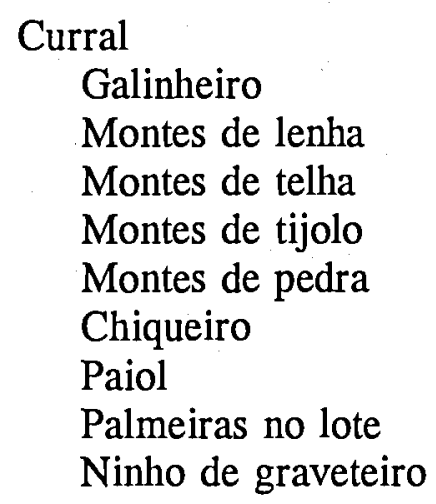

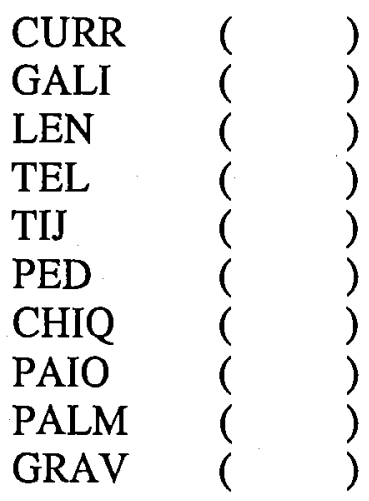

Qual a distância da casa até os anexos?

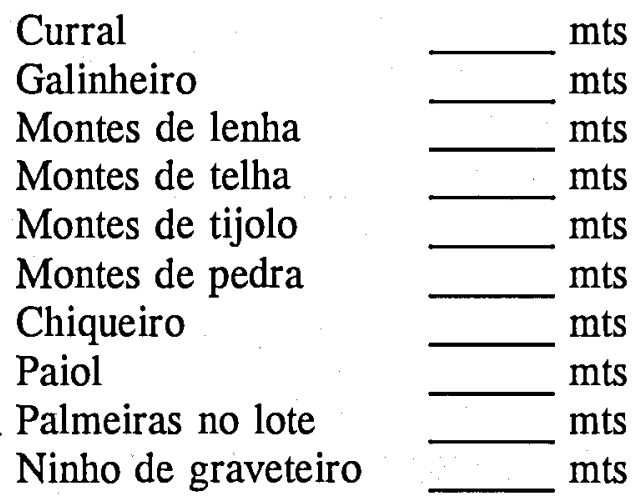

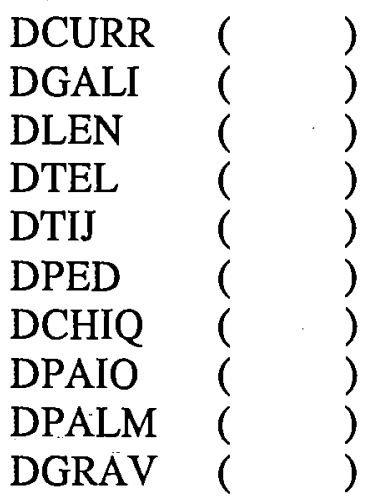

Caracterização dos anexos

(1) Pau-a-pique

(2) Caiçara 
(3) Folha de buriti

PANEXOCH ( )

(4) Folha de guariroba

PANEXOP

(5) Capim

(6) Telha

(7) Outra

Qual a data da última borrifação?

Codifique s/ informação (99) s/ borrifação (00)

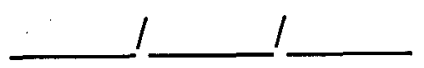

MESBOR ( ) ANOBOR ( )

Mostrar a preparação de insetos

Codifique Não (1) Sim (2)

Você já viu algum destes insetos em alguma casa que você morou?

VBAR

se negativo, vá para ítem 5

Qual destes barbeiros você tem certeza que já viu dentro de casa nos últimos 5 anos?

CIDTR ( )

$\overline{1} \overline{2} \frac{7}{4} \overline{5} \overline{6} \overline{7} \frac{}{8}$

ident. positiva

Não (1) Sim (2)

Qual destes barbeiros você tem certeza que já viu no quintal nos últimos 5 anos?

AIDTR

$\frac{7}{2} \frac{7}{3} \frac{}{5} \frac{7}{6} \frac{7}{8}$

ident. positiva

Não (1) Sim (2)

\section{CAPTURA DE TRIATOMÍNEOS:}

Codifique Não (1) Sim (2)

Captura de triatomíneos: 
Local de captura de triatomíneos:

Codifique: não (1) $\operatorname{sim}(2)$

$\begin{array}{ll}\text { Domicílio } & (\text { ) } \\ \text { Quarto } & (\text { ) } \\ \text { Sala } & \text { ( ) } \\ \text { Cozinha } & \text { ( ) } \\ \text { Outro } & (\text { ) } \\ \text { Anexos } & (\text { ) } \\ \text { Curral } & (\text { ) } \\ \text { Galinheiro } & (\text { ) } \\ \text { Paiol } & (\text { ) } \\ \text { Outro } & (\text { ) }\end{array}$

$\begin{array}{ll}\text { DCAP } & (\quad) \\ \text { DCAPQ } & (\quad) \\ \text { DCAPS } & (\quad) \\ \text { DCAPC } & (\quad) \\ \text { DCAPO } & (\quad) \\ \text { ACAP } & (\quad) \\ \text { ACAPC } & (\quad) \\ \text { ACAPG } & (\quad) \\ \text { ACAPP } & (\quad) \\ \text { ACAPO } & (\quad, \quad)\end{array}$

Vestígios dos triatomíneos:

Codifique: não (1) sim (2)

Domicílio:

DVTR ( )

Exúvias

Ovos

Cório

Fezes

Asas

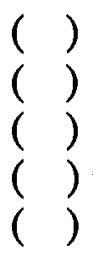

DEXU

DOVO ( )

DCOR ( )

$\begin{array}{ll}\text { DFEZ } & (\quad) \\ \text { DASA } & (\quad)\end{array}$

Anexos:

AVTR ( )

$\begin{array}{ll}\text { Exúvias } & (\text { ) } \\ \text { Ovos } & (\text { ) } \\ \text { Cório } & (\text { ) } \\ \text { Fezes } & (\text { ) } \\ \text { Asas } & (\text { ) }\end{array}$

$\begin{array}{ll}\text { AEXU } & (\quad) \\ \text { AOVO } & (\quad) \\ \text { ACOR } & (\quad) \\ \text { AFEZ } & (\quad)\end{array}$

Caracterização dos triatomíneos encontrados

Codifique Não (1) Sim (2)

Ninfa

Adulto

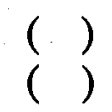

$\begin{array}{ll}\text { ENINF } & (\quad) \\ \text { ADUL } & (\quad)\end{array}$ 


\section{INFORMAÇÕES SOBRE A CRIANÇA}

5.1 Doenças anteriores graves:

Não (1) Sim (2) Sem inf (9)

DOGRAV ( )

Se sim, qual a doença?

5.2 Já foi internado em hospital alguma vez?

Não (1) Sim (2) Sem inf (9)

ano

I ano

$\begin{array}{ll}\text { HOSP } & (\quad)\end{array}$

5.3 Já recebeu transfusão de sangue alguma vez? codifique o número de vezes

TRANS $(\quad)$

se negativo passe para 5.4

5.3.1 Teve alguma doença poucos meses depois da transfusão de sangue?

não aplica (0)

não (1), hepatite (2), doença do coração (3)

anemia (4), sintoma mal definido (5), outra (6)

DPT

5.4 Já foi picado por barbeiro?

Não (1) Sim (2) Não sabe (9)

PBAR

Se a resposta foi não, passe para 5.5

5.4.1 Se Sim há quanto tempo meses

MPIC $\quad(\quad)$

anos

APIC

5.4.2 Fez algum tratamento?

Não (1) Sim (2) Sem inf (9)

-TRAT $(\quad)$

Não aplica (0)

5.4.3 Qual? 
6. LABORATÓRIO - Identificação e coproscopia

6.1 Domicílio

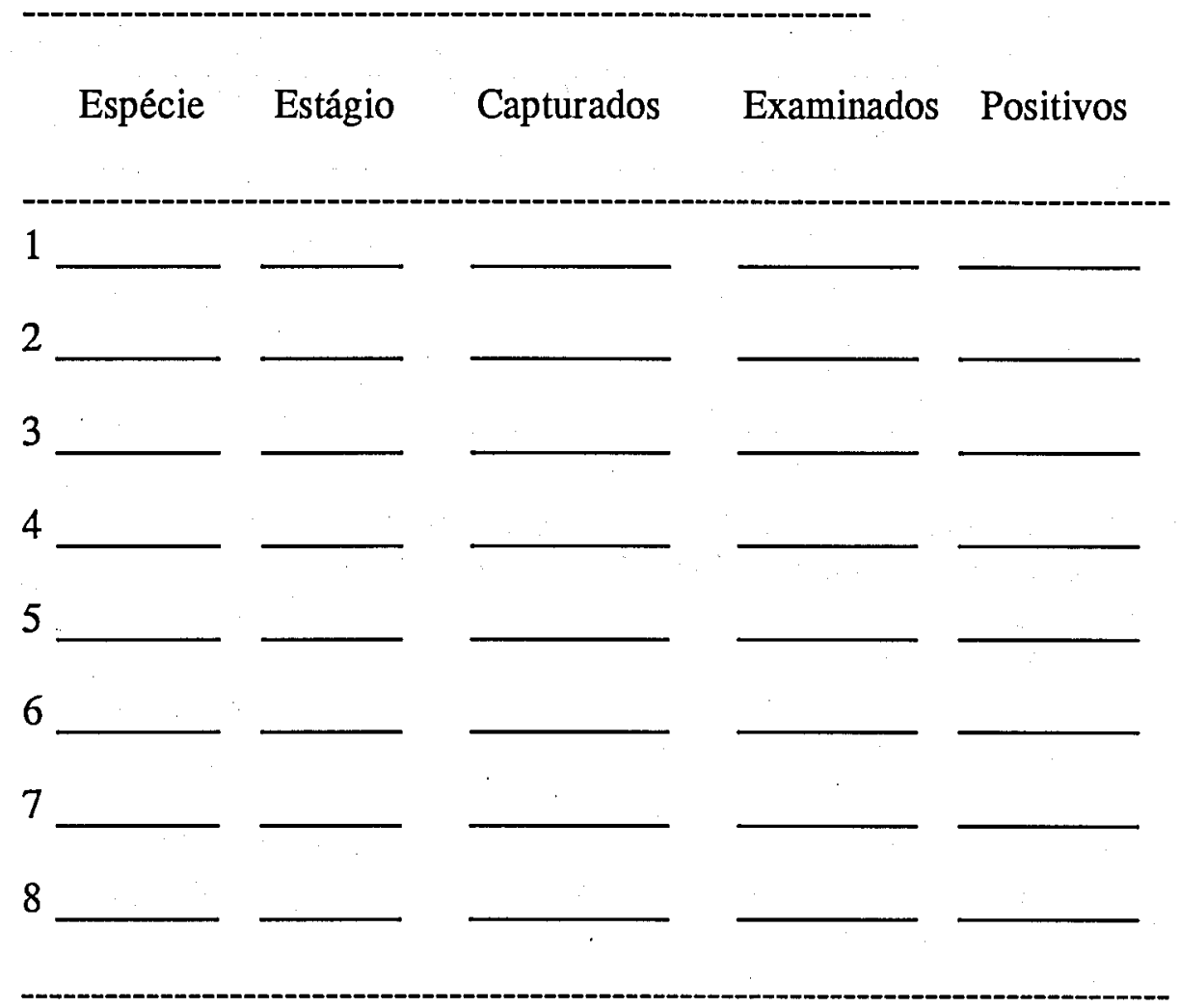

Codifique quanto às espécies em DNTE (número de triatomíneos encontrados no domicílio) e DNTI (número de triatomíneos infectados no domicílio):

$\begin{array}{ll}\text { DNTE1 } & (\text { ) } \\ \text { DNTI1 } & (\text { ) } \\ \text { DNTE2 } & (\quad) \\ \text { DNTI2 } & (\quad) \\ \text { DNTE3 } & (\quad) \\ \text { DNTI3 } & (\quad)\end{array}$

6.2 Peridomicílio

Espécie Estágio Capturados Examinados Positivos

1 


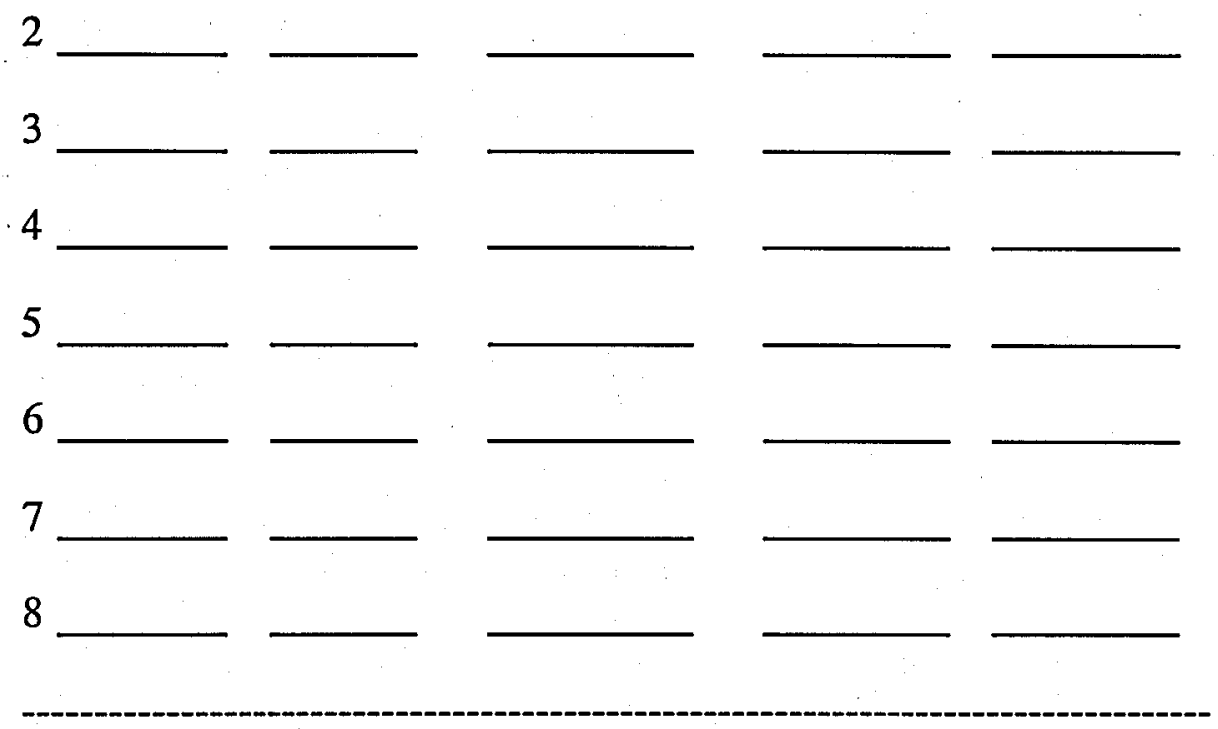

Codifique quanto às espécies em ANTE (número de triatomíneos encontrados nos anexos) e ANTI (número de triatomíneos infectados nos anexos):

ANTE1 ( )
ANTI1 ( )
ANTE2 $($ )
ANTI2 ( )
ANTE3 ( )
ANTI3 ( )


ANEXO 3

\section{ESTUDO EPIDEMIOLÓGICO EM ESCOLARES ROTEIRO PARA CODIFICAÇÃO DO QUESTIONÁRIO}

\section{IDENTIFICAÇÃO}

NOID : Número de ordem do questionário do estudo caso-controle

NO : Número de ordem da ficha de identificação do rastreamento sorológico

CACO : Identifique os participantes em Controle $=0$ e Caso $=1$

AGE : Codifique a idade em anos completos

SEX : Codifique quanto ao sexo: Masculino $=1$ Feminino $=2$

CASA : Identifique o número da casa (SUCAM), onde "C" = "."

NASC : Registre a data de nascimento

COM : Codifique quanto a comunidade onde reside

COM1 : Nome da comunidade quando o local de moradia é diferente da localização da escola

MUN : Codifique o município em:

Posse $=1$ Guarani de Goiás=2 Simolândia=3

\section{HISTÓRIA DE RESWÊNCIA}

UR : Codifique quanto ao local de moradia atual.

Urbano=1 $\quad$ Rural $=2$

PA : Codifique em relação às características da parede da moradia atual

tijolo com reboque $=1$ tijolo $\mathrm{s} /$ reboque $=2$

pau-a-pique $\mathrm{c} /$ reboque $=3$ madeira $=4$

adobe $s /$ reboque $=5$ folha de palmeira ou similar $=6$

barro com madeira $=7$ tijolo/pintada $=8$

adobe/pintada $=9$ adobe $\mathrm{c} /$ reboque $=10$

outros $=11$

TETO Codifique em relação às características do teto da moradia atual

telha de barro $=1$ telha de cimento amianto $=2$

capim $=3$ zinco $=4$ folha de palmeira $=5$

buriti $=6$ indaiá $=7$ guariroba $=8$ outros $=9$ 
PISO : Codifique em relação aos anos completos de moradia em zona rural

\section{AVALIAÇÃo DA RESIDÊNCIA ATUAL}

NCOM : Número de cômodos da moradia atual

NPES : Número de moradores na casa

YMOR : Tempo de moradia, em anos completos

Codifique Não=1 Sim=2 S/ informação=9

CP : Casa própria

ESTAL : Estoque de alimentos dentro de casa

MLEN : Estoque de lenha dentro de casa

MTEL : Estoque de telha dentro de casa

MTIJ : Estoque de tijolos dentro de casa

MPED : Montes de pedra dentro de casa

Animais vivendo dentro de casa

Codifique Não=1 Sim=2 S/ informação=9

GAL : Galinhas vivendo dentro de casa

CAO : Cão vivendo dentro de casa

POR : Porcos vivendo dentro de casa

GAT : Gatos vivendo dentro de casa

OUT : Outros animais vivendo dentro de casa

ROED : Presença de roedores e/ou gambás dentro de casa

Caracterização dos arredores e anexos

Codifique Não=1 $\operatorname{Sim}=2 \mathrm{~s} / \mathrm{inf}=9$ em relação a presença ou não de anexos e dos seguintes ítens nos arredores

CURR : Curral

GALI : Galinheiro

LEN : Montes de lenha

TEL : Montes de telha

TIJ : Montes de tijolo

PED : Montes de pedra 
CHIQ : Chiqueiro

PAIO : Paiol

PALM : Palmeiras no lote

GRAV : Ninho de graveteiro

Codifique com relação à distância em metros entrre a casa e os anexos e/ou distância entre a casa e os ítens encontrados nos arredores. Se não existe codifique como 0.

DCURR : Distância em metros da casa até o curral

DGALI : Distância em metros da casa até o galinheiro

DLEN : Distância em metros da casa até os montes de lenha

DTEL : Distância em metros da casa até os montes de telha

DTIJ : Distância em metros da casa até os montes de tijolo

DPED : Distância em metros da casa até os montes de pedra

DCHIQ : Distância em metros da casa até o chiqueiro

DPAIO : Distância em metros da casa até o paiol

DPALM : Distância em metros da casa até as palmeiras

DGRAV : Distância em metros da casa até o ninho de graveteiro

Codifique em relação à caracterização dos anexos em:

pau-a-pique $=1$ caiçara $=2$ folha de buriti=3

folha de guariroba $=4$ capim $=5$ telha $=6$

outra $=7$ não aplica $=0$

PANANEXC : Caracterize a parede do curral

PANANEXG : Caracterize a parede do galinheiro

PANANEXCH: Caracterize a parede do chiqueiro 
PANANEXP : Caracterize a parede do paiol

TANEXC : Caracterize o teto do curral

TANEXG : Caracterize o teto do galinheiro

TANEXCH : Caracterize o teto do chiqueiro

TANEXP : Caracterize o teto do paiol

Antecedentes de borrifação do domicílio

Codifique em relação ao mes e ano da última borrifação, utilize 00 para sem borrifação e 99 para s/ informação

MESBOR : Mes da última borrifação

ANOBOR : Ano da última borrifação

Identificação de insetos

Mostre a caixa de acrílico com a preparação de insetos.

Codifique Não=1 $\operatorname{Sim}=2 \quad$ S/informação $=9$

VBAR : Pergunte ao entrevistado se ele já viu algum destes insetos em alguma casa onde morou.

Se negativo passe para o ítem 5 (Informações sobre a criança)

Peça ào entrevistado para identificar o(s) triatomíneo(s) que viu dentro de casa nos últimos 5 anos. Se não aplica $=0$

CIDTR : Codifique Não $=1$ se a identificação foi incorreta

(insetos 7 e 8) e Sim=2 se a identificação foi correta (insetos de 1 a 6) 
Peça ao entrevistado para identificar o(s) triatomíneo(s) que viu no quintal nos últimos 5 anos. Se não aplica $=0$

AIDTR : Codifique Não=1 se a identificação foi incorreta

(insetos 7 e 8) e Sim $=2$ se a identificação foi correta (insetos de 1 a 6 )

\section{CAPTURA DE TRIATOMÍNEOS}

Codifique Não=1 $\operatorname{Sim}=2$ Sem informação=9

CAP : Codifique com relação à captura de triatomíneos, se negativo passe para o ítem Vestígios de triatomíneos

DCAP : Captura no domicílio, se não aplica codifique 0 , se negativo passe para o ítem Captura nos anexos

Local de captura no domicílio, se não se aplica codifique 0

DCAPQ : Captura de triatomíneos no quarto

DCAPS : Captura de triatomíneos na sala

DCAPC : Captura de triatomíneos na cozinha

DCAPO .: Captura de triatomíneos em outro local da casa

ACAP : Captura nos anexos, se não aplica codifique 0

Local de captura nos anexos, se não aplica codifique 0

ACAPC : Captura de triatomíneos no curral

ACAPG : Captura de triatomíneos no galinheiro

ACAPP : Captura de triatomíneos no paiol 
ACAPO : Captura de triatomíneos em outro anexo

Vestígios de triatomíneos

DVTR : Codifique em relação à localização de vestígios de triatomíneos no domicílio, se negativo passe para vestígios de triatomíneos nos anexos

Caracterização dos vestígios encontrados no domicílio, se não aplica codifique 0

DEXU : Presença de exúvias (esqueletos) de triatomíneos no domicílio

DOVO . : Presença de ovos de triatomíneos no domicílio

DCOR : Presença de cório (casca) de triatomíneos no domicílio

DFEZ : Presença de fezes de triatomíneos no domicílio

DASA : Presença de asas de triatomíneos no domicílio

AVTR : Codifique em relação à localização de vestígios de triatomíneos nos anexos

Caracterização dos vestígios encontrados nos anexos, se não aplica codifique 0

AEXU : Presença de exúvias (esqueletos) de triatomíneos nos anexos

AOVO : Presença de ovos de triatomíneos nos anexos

ACOR : Presença de cório (casca) de triatomíneos nos anexos

AFEZ : Presença de fezes de triatomíneos nos anexos

AASA : Presença de asas de triatomíneos nos anexos

Caracterização dos triatomíneos encontrados, se não aplica codifique 0

ENINF : Codifique Não=1 e $\operatorname{Sim}=2$ se foram encontradas ninfas de triatomíneos no domicílio

ADUL : Codifique Não $=1$ e $\operatorname{Sim}=2$ se foram encontradas espécies adultas de triatomíneos no domicílio 


\section{INFORMAÇÕES SOBRE A CRIANÇA}

DOGRAV : Antecedentes de doença grave. Anote qual a doença.

HOSP : Já foi internado em hospital alguma vez?

Codifique Não=1 Sim=2 S/ informação=9.

YHOSP : Anote o ano da última internação. Se não foi internado codifique 00 , se não sabe se foi internado ou o ano da internação codifique 99

TRANS : Já recebeu transfusão de sangue alguma vez?

Codifique o número de vezes, se não sabe codifique 9 , se 0

passe para o ítem picada de barbeiro

DPT : Codifique com relação a ocorrência de alguma doença pouco depois da transfusão sanguínea. Se não se aplica codifique 0 e codifique 9 para sem informação.

PBAR : Codifique com relação a antecedentes de picada por barbeiro em Não=1 $\operatorname{Sim}=2$ Não sabe $=9$

Se positivo anote quando ocorreu, se não se aplica codifique 00 , se não sabe a época codifique 99:

MPIC : Há quanto tempo foi picado em meses

APIC : Há quanto tempo foi picado em anos

Codifique Não=1 Sim=2 S/ informação $=9$

TRAT : Codifique em relação a antecedentes de tratamento para Doença de Chagas 


\section{LABORATÓRIO - Identificação e coproscopia}

Preencher quando forem encontrados triatomíneos no domicílio e/ou anexos

\subsection{Domicílio}

Se a captura de triatomíneos for positiva $(\mathrm{CAP}=2)$ e a Captura de triatomíneos no domicílio (casa) for positiva $(\mathrm{DCAP}=2)$, codifique quanto às espécies em:

DNTE (Número de triatomíneos encontrados no domicílio)

DNTI (Número de triatomíneos infectados por domicílio)

Os números de 1 a 3 representam às espécies encontradas

$$
\begin{aligned}
& 1=\text { Triatoma sordida } \\
& 2=\text { Triatoma infestans } \\
& 3=\text { Outra espécie }
\end{aligned}
$$

Se a captura de triatomíneos for positiva $(\mathrm{CAP}=2)$ e a captura de triatomíneos no(s) anexo(s) for positiva $(\mathrm{ACAP}=2)$,

codifique quanto as espécies em:

ANTE (Número de triatomíneos encontrados no(s) anexo(s))

ANTI (Número de triatomíneos infectados por anexo(s)).

Os números de 1 a 3 representam as espécies encontradas

$$
\begin{aligned}
& 1=\text { Triatoma sordida } \\
& 2=\text { Triatoma infestans } \\
& 3=\text { Outra espécie }
\end{aligned}
$$


Anexo 4

Cálculo do $\Phi_{\text {mh }}$

(Odds ratio)

Distribuição dos triplos caso-controle (caso, controle 1, controle 2)

$$
\mathrm{N}^{\mathrm{o}} \text { de controles expostos (m) }
$$

$\begin{array}{lllll}0 & 1 & 2 & \ldots & \mathrm{M}\end{array}$

\begin{tabular}{|c|c|c|c|c|c|}
\hline \multirow[t]{3}{*}{ não exposto (0) } & no,o & $\mathrm{n} 0,1$ & $\mathrm{n}_{0,2}$ & $\ldots$ & $\mathrm{n} 0, \mathrm{M}$ \\
\hline & & & & & \\
\hline & $\mathrm{n} 1,0$ & $\mathrm{n}_{1,1}$ & $\mathrm{n} 1,2$ & $\ldots$ & $\mathrm{n}_{1, \mathrm{M}}$ \\
\hline
\end{tabular}

no,0 = número de triplos com casos e controles não expostos

no,1 = número de triplos com 1 controle exposto e casos não expostos

no,2 = número de triplos com 2 controles expostos e casos não expostos

$\mathrm{n} 1,0=$ número de triplos com caso exposto e nenhum controle exposto

$\mathrm{n} 1,1=$ número de triplos com caso e 2 controles expostos

$\mathrm{n} 1,2=$ número de triplos com caso exposto e 2 controles expostos

$\mathrm{n} 0, \mathrm{M}=$ número de triplos com caso exposto e $\mathrm{M}$ controles expostos

$\mathrm{n} 1, \mathrm{M}=$ número de triplos com caso exposto e $\mathrm{M}$ controles expostos

$$
\Psi_{m h}=\frac{\sum_{M} \sum_{m=1}^{M}(M-m+1) n_{1, m-1, M} /(M+1)}{\sum_{M} \sum_{m=1}^{M} m n_{0, m, M} /(M+1)}
$$

onde:

$\Phi_{m h}=$ Estimativa de Odds Ratio de Mantel-Haenszel

$\mathrm{M} \quad=$ número de controles

$\mathrm{m} \quad=$ número de controles expostos

$\mathrm{n}_{1, \mathrm{~m}-1, \mathrm{M}}=$ número de triplos nos quais os casos $\mathrm{e} \mathrm{m}$ dos $\mathrm{M}$ controles são expostos 
Numerador:

$1: 1$

exposto (1)

\begin{tabular}{|c|c|}
\hline $1 / 2$ & 0 \\
$\mathrm{n} 1,0$ & $\mathrm{n}_{1,1}$ \\
\hline
\end{tabular}

$1: 2$

exposto (1)

\begin{tabular}{|c|c|c|}
\hline $2 / 3$ & $1 / 3$ & 0 \\
$\mathrm{n} 1,0$ & $\mathrm{n} 1,1$ & $\mathrm{n} 1,2$ \\
\hline
\end{tabular}

Denominador:

$1: 1$

não exposto (0) \begin{tabular}{|c|c|}
\hline 0 & $1 / 2$ \\
$\mathrm{n} 0,0$ & $\mathrm{n} 0,1$ \\
\hline
\end{tabular}

$1: 2$

não exposto (0) \begin{tabular}{|c|c|c|}
\hline 0 & $1 / 3$ & $2 / 3$ \\
$\mathrm{n} 0,0$ & $\mathrm{n} 0,1$ & $\mathrm{n} 0,2$ \\
\hline
\end{tabular}




\section{Cálculo do $\Psi_{m h}$}

utilizando como exemplo a Tabela 5.2-1 abaixo.

Tabela 5.2-1.

Casos e controles de acordo com número de triplos expostos à variável identificação de triatomíneo estratificada por domićlio e anexo, com os respectivos odds ratio (OR) pareados e limites de confiança (LC) $95 \%$.

\begin{tabular}{|c|c|c|c|c|}
\hline $\begin{array}{l}\text { Casos } \\
(n=149)\end{array}$ & $\begin{array}{c}\text { Número } \\
0\end{array}$ & $\begin{array}{l}\text { trole } \\
=298) \\
\text { ontr } \\
1\end{array}$ & $\begin{array}{l}\text { expostos } \\
2\end{array}$ & $\begin{array}{l}\text { RLC }^{\mathrm{b}} \\
\text { OR (LC 95\%) }\end{array}$ \\
\hline \multicolumn{5}{|c|}{ Identificação de triatomíneo $^{c}$} \\
\hline não & 0 & 0 & 3 & 1 \\
\hline $\operatorname{sim}$ & 4 & 34 & 106 & $7,7(2,3-25,5)$ \\
\hline \multicolumn{5}{|c|}{ domicílio $^{\mathrm{d}}$} \\
\hline กล̃o & 1 & 3 & 5 & 1 \\
\hline $\operatorname{sim}$ & 4 & 43 & 91 & $3,6(1,6-7,8)$ \\
\hline \multicolumn{5}{|c|}{$\operatorname{anexos}^{\mathrm{e}}$} \\
\hline não & 70 & 23 & 3 & 1 \\
\hline $\operatorname{sim}$ & 23 & 14 & 5 & $2,0(1,2-3,3)$ \\
\hline
\end{tabular}

- Resultados apresentados preservando os 149 triplos (caso, controle1, controle2)

${ }^{\circ} \mathrm{RLC}=$ Regressão logística condicional

' Informação fornecida pelo morador referente a presença de barbeiro na moradia ou anexos nos últimos 5 anos.

147 triplos ( 3 registros sem informação)

d 147 triplos ( 5 registros sem informação)

- 138 triplos (20 registros sem informação)

$\Psi_{m h} . \quad=$ Identificação de triatomíneo (domicílio ou anexo):

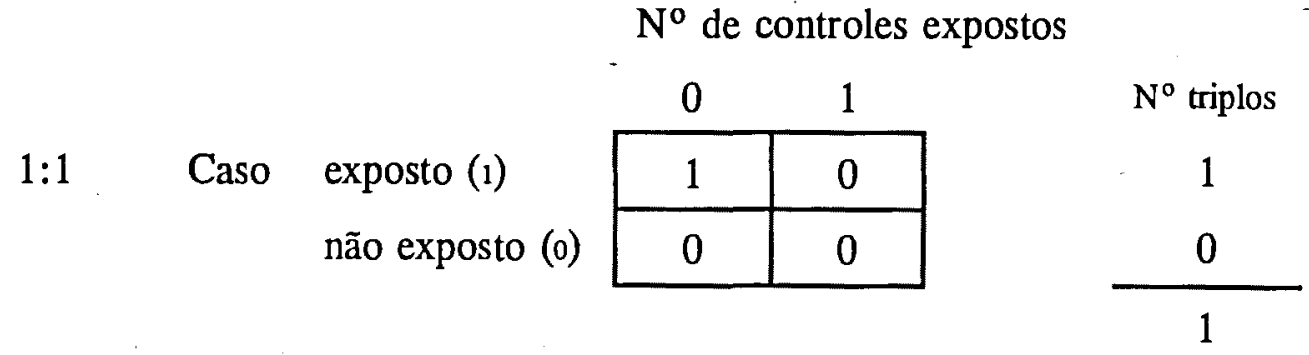




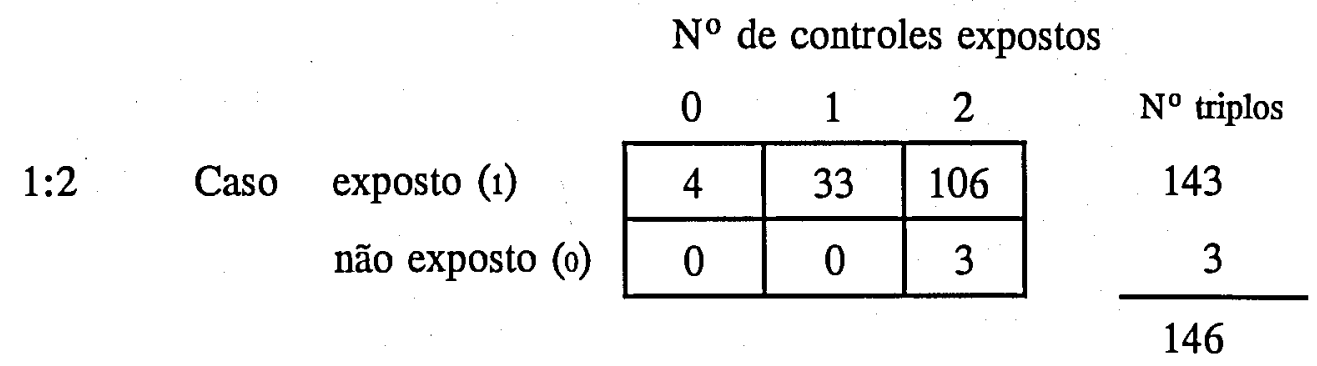

Total Geral de Triplos $=147$

$$
\Phi m h=\frac{\left(\frac{1}{2}\right)+\left(\frac{2}{3} \times 4\right)+\frac{33}{3}}{\frac{2 \times 3}{3}}=\frac{0,5+2,666+11}{2}=7,1
$$

$\Phi_{m h}=$ Identificação de triatomíneo no domicílio
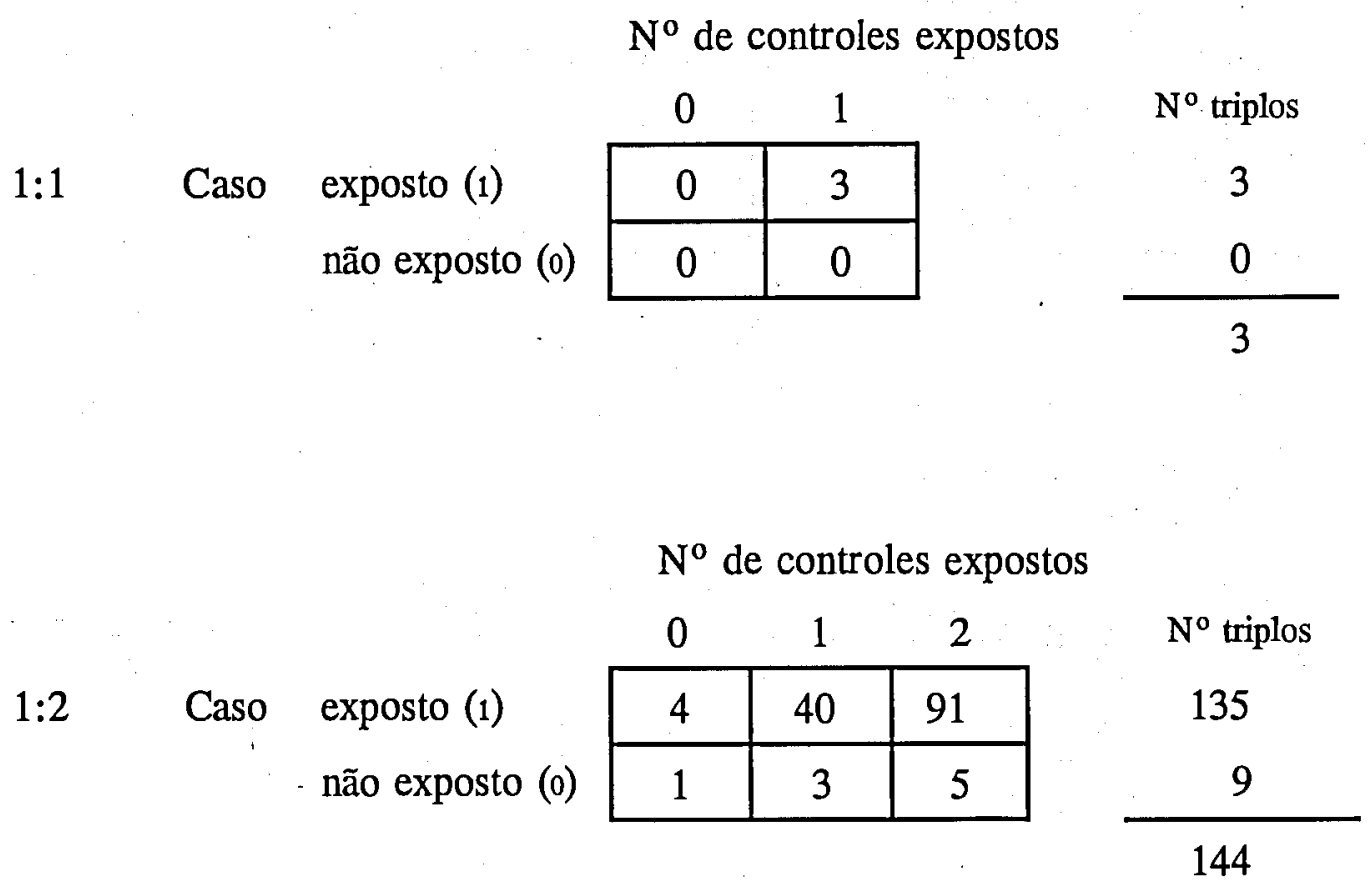
Total Geral de Triplos $=147$

$$
\Psi_{m h}=\frac{\left(\frac{2 \times 3}{4}\right)+\left(\frac{40}{3}\right)}{\left(\frac{1 \times 3}{3}\right)+\left(\frac{2 \times 5}{3}\right)}=\frac{1,5+13,333}{1+3,333}=3,4
$$

$\varphi_{m i}=$ Identificação de triatomíneo nos anexos

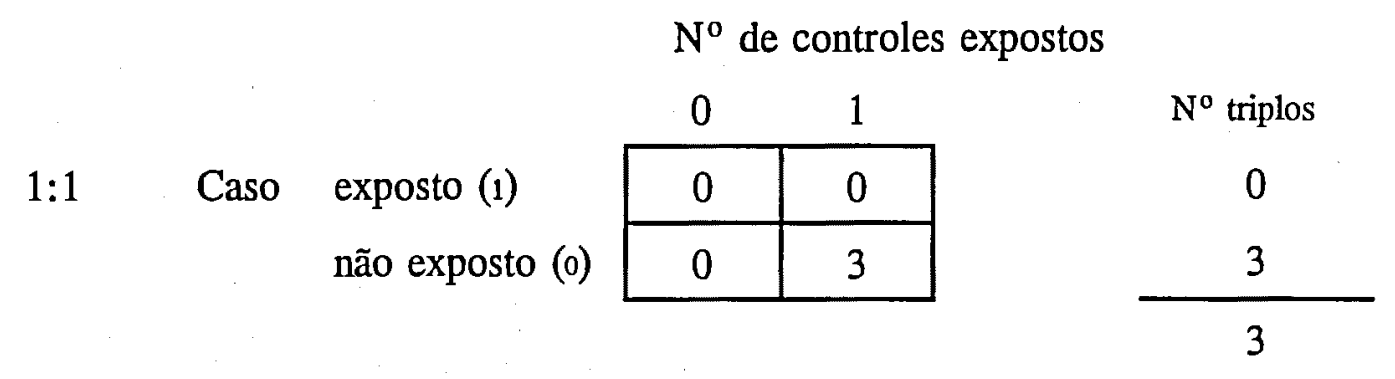

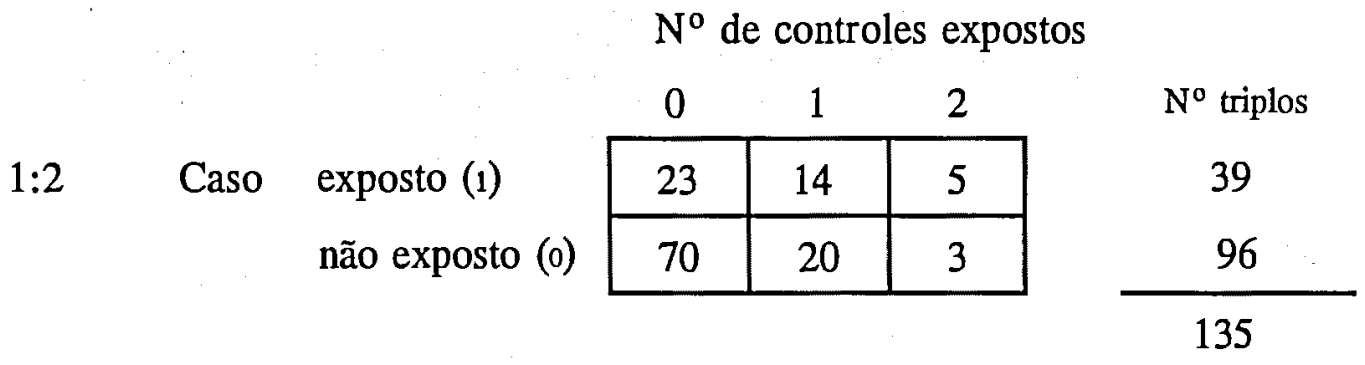

Total Geral de Triplos $=138$

$$
\Psi_{m h}=\frac{\left(\frac{2}{3} \times 23\right)+\left(\frac{14}{3}\right)}{\left(\frac{1 \times 20}{3}\right)+\left(\frac{2 \times 3}{3}\right)}=\frac{15,333+4,6}{6,666+2}=2,3
$$

